\title{
Synthesis of an Iridoid-Inspired Compound Collection and the Discovery of
}

Autophagy Inhibitors

Peter Schröder ${ }^{1}$, Jonathan O. Bauer ${ }^{2}$, Carsten Strohmann ${ }^{2}$, Kamal Kumar*1, and Herbert Waldmann* $*^{1,2}$

${ }^{1}$ Max Planck Institute of Molecular Physiology, Otto-Hahn-Str. 11, 44227 Dortmund, Germany.

${ }^{2}$ Technical University Dortmund, Faculty of Chemistry and Chemical Biology, Otto-HahnStr. 6, 44221 Dortmund, Germany.

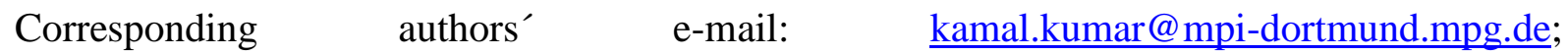
herbert.waldmann@mpi-dortmund.mpg.de 


\section{Table of contents}

Assay description and measured $\mathrm{IC}_{50}$ values

$\begin{array}{ll}\text { Spectroscopic data for 9a } & 9\end{array}$

$\begin{array}{ll}\text { Spectroscopic data for 9b } & 10\end{array}$

$\begin{array}{ll}\text { Spectroscopic data for 16a } & 11\end{array}$

$\begin{array}{lr}\text { Spectroscopic data for } \mathbf{1 6 b} & 12\end{array}$

$\begin{array}{ll}\text { Spectroscopic data for 16c } & 13\end{array}$

$\begin{array}{ll}\text { Spectroscopic data for 17a } & 14\end{array}$

$\begin{array}{ll}\text { Spectroscopic data for } \mathbf{1 7 b} & 15\end{array}$

$\begin{array}{ll}\text { Spectroscopic data for 17c } & 16\end{array}$

$\begin{array}{ll}\text { Spectroscopic data for 13a } & 17\end{array}$

$\begin{array}{ll}\text { Spectroscopic data for 13b } & 18\end{array}$

$\begin{array}{ll}\text { Spectroscopic data for 13c } & 19\end{array}$

$\begin{array}{ll}\text { Spectroscopic data for 13d } & 20\end{array}$

$\begin{array}{ll}\text { Spectroscopic data for 19a } & 21\end{array}$

Spectroscopic data for $\mathbf{1 9 b} \quad 22$

$\begin{array}{ll}\text { Spectroscopic data for 19c } & 23\end{array}$

$\begin{array}{ll}\text { Spectroscopic data for 7a } & 24\end{array}$

$\begin{array}{ll}\text { Spectroscopic data for } \mathbf{7 b} & 25\end{array}$

$\begin{array}{ll}\text { Spectroscopic data for 7c } & 26\end{array}$

$\begin{array}{ll}\text { Spectroscopic data for } \mathbf{7 d} & 27\end{array}$

$\begin{array}{ll}\text { Spectroscopic data for 8a } & 28\end{array}$

$\begin{array}{ll}\text { Spectroscopic data for } \mathbf{8 b} & 29\end{array}$

Spectroscopic data for 8c $\quad 30$

$\begin{array}{ll}\text { Spectroscopic data for 20a } & 31\end{array}$

Spectroscopic data for $\mathbf{2 0 b} \quad 32$

Spectroscopic data for 20c 33

$\begin{array}{ll}\text { Spectroscopic data for 20d } & 34\end{array}$

$\begin{array}{ll}\text { Spectroscopic data for 20e } & 35\end{array}$

Spectroscopic data for 20f 36

$\begin{array}{ll}\text { Spectroscopic data for } \mathbf{2 0 g} & 37\end{array}$

$\begin{array}{ll}\text { Spectroscopic data for } \mathbf{2 0 h} & 38\end{array}$ 
Spectroscopic data for $\mathbf{2 0 i}$

Spectroscopic data for $\mathbf{2 0} \mathbf{j}$

Spectroscopic data for $\mathbf{2 0 k}$

Spectroscopic data for 201 42

Spectroscopic data for $20 \mathrm{~m}$ 43

Spectroscopic data for 20n 44

Spectroscopic data for $\mathbf{2 0 0}$ 45

Spectroscopic data for $\mathbf{2 0 p}$ 46

Spectroscopic data for $\mathbf{2 0 q}$ 47

Spectroscopic data for $20 \mathrm{r}$ 48

Spectroscopic data for $\mathbf{2 0 s}$ 49

Spectroscopic data for $\mathbf{2 0 t}$ 50

Spectroscopic data for $\mathbf{2 0 u}$ 51

Spectroscopic data for $21 a$ 52

Spectroscopic data for $\mathbf{2 1 b}$ 53

Spectroscopic data for 21c 54

Spectroscopic data for 21d 55

Spectroscopic data for $21 \mathrm{e}$ 56

Spectroscopic data for $21 \mathbf{f}$ 57

Spectroscopic data for $\mathbf{2 1 g}$ 58

Spectroscopic data for $\mathbf{2 1 h}$ 59

Spectroscopic data for $\mathbf{2 1 i}$ 60

Spectroscopic data for $\mathbf{2 1} \mathbf{j}$ 61

Spectroscopic data for $\mathbf{2 1 k}$ 62

Spectroscopic data for $\mathbf{2 1 1}$ 63

$\begin{array}{ll}\text { Spectroscopic data for } \mathbf{2 1 m} & 64\end{array}$

Spectroscopic data for 21n $\quad 65$

$\begin{array}{ll}\text { Spectroscopic data for 210 } & 66\end{array}$

$\begin{array}{ll}\text { Spectroscopic data for 21p } & 67\end{array}$

$\begin{array}{ll}\text { Spectroscopic data for 21q } & 68\end{array}$

$\begin{array}{ll}\text { Spectroscopic data for 21r } & 69\end{array}$

$\begin{array}{ll}\text { Spectroscopic data for 21s } & 70\end{array}$

$\begin{array}{ll}\text { Spectroscopic data for 21t } & 71\end{array}$

$\begin{array}{ll}\text { Spectroscopic data for } 21 \mathbf{u} & 72\end{array}$ 
Spectroscopic data for $\mathbf{2 1 v}$ 73

Crystallographic data for $\mathbf{7 b}$ 74

Crystallographic data for 20a 79

Crystallographic data for $\mathbf{2 1 1}$ 85 


\section{Biological Data}

\section{Screening for autophagy modulators:}

High-throughput screening for autophagy modulators was performed at the Compound management and screening center (COMAS) in Dortmund, Germany. MCF7-GFP-LC3 cells (4000 cells per well) were seeded in $25 \mu 1$ medium in a 384 well Greiner $\mu$ clear plate and incubated $\left(37^{\circ} \mathrm{C}, 5 \% \mathrm{CO}_{2}\right)$ overnight. Cells were then washed by a plate washer three times with 1X PBS followed by a final aspiration of the washing buffer. The addition of $25 \mathrm{nl}$ of compound solution (10 mM stock solution in DMSO) was then carried out with an echo dispenser (Labcyte, Echo 520 dispenser). Addition of medium to induce autophagy was carried out with a Multidrop Combi. $25 \mu$ l EBSS containing $50 \mu \mathrm{M}$ Chloroquine was used for starvation-induced autophagy and $25 \mu 1$ medium containing $50 \mu 1$ Chloroquine and $100 \mathrm{nM}$ Rapamycin was used for rapamycin-induced autophagy screening. Following a three hours of incubation $\left(37^{\circ} \mathrm{C}, 5 \% \mathrm{CO}_{2}\right)$, cells were fixed by addition of $25 \mu 11: 4$ formaldehyde in 1X PBS + 1:500 Hoechst and incubation for $20 \mathrm{~min}$ at room temperature. Cells were then washed three times with 1X PBS. Four images per well were taken with ImageXpress Micro $\mathrm{XL}$ at 20x. Automated image analysis was performed using the granularity setting of MetaXpress Software. Dose response analyses were carried out using three-fold dilutions over eight steps starting from $10 \mu \mathrm{M}$. IC50 calculations were done using Quattro Workflow software. 
Table 1: Screening data for autophagy inhibition for compounds 20a - 20u. Data were determined with $\mathrm{n}=3$. n.a. $=$ not active.

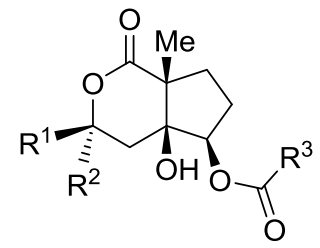

\begin{tabular}{|c|c|c|c|c|c|c|c|}
\hline No. & $\mathbf{R}^{1} / \mathbf{R}^{2}$ & $\mathbf{R}^{3}$ & $\begin{array}{l}\mathrm{IC}_{50} \\
{[\boldsymbol{\mu M}]}\end{array}$ & No. & $\mathbf{R}^{1} / \mathbf{R}^{2}$ & $\mathbf{R}^{3}$ & $\begin{array}{l}\mathbf{I C}_{50} \\
{[\boldsymbol{\mu M}]}\end{array}$ \\
\hline 20a & $\mathrm{Me} / \mathrm{Me}$ & & n.a. & $20 k$ & $\mathrm{Me} / \mathrm{Me}$ & & n.a. \\
\hline $20 b$ & $\mathrm{Me} / \mathrm{Me}$ & & n.a. & 201 & $\mathrm{Me} / \mathrm{Me}$ & & n.a. \\
\hline 20c & $\mathrm{Me} / \mathrm{Me}$ & & n.a. & $20 \mathrm{~m}$ & $\mathrm{Me} / \mathrm{Me}$ & & $5.7 \pm$ \\
\hline 20d & $\mathrm{Me} / \mathrm{Me}$ & & n.a. & $20 n$ & $\mathrm{Et} / \mathrm{Et}$ & & n.a. \\
\hline $20 e$ & $\mathrm{Me} / \mathrm{Me}$ & & n.a. & 200 & $\mathrm{Et} / \mathrm{Et}$ & & n.a. \\
\hline $20 f$ & $\mathrm{Me} / \mathrm{Me}$ & & n.a. & $20 p$ & $\mathrm{Et} / \mathrm{Et}$ & & n.a. \\
\hline $20 \mathrm{~g}$ & $\mathrm{Me} / \mathrm{Me}$ & & n.a. & $20 q$ & $\mathrm{Et} / \mathrm{Et}$ & & n.a. \\
\hline $20 \mathrm{~h}$ & $\mathrm{Me} / \mathrm{Me}$ & & n.a. & $20 r$ & $\mathrm{Et} / \mathrm{Et}$ & & n.a. \\
\hline $20 \mathrm{i}$ & $\mathrm{Me} / \mathrm{Me}$ & & n.a. & $20 s$ & $\mathrm{Et} / \mathrm{Et}$ & & n.a. \\
\hline $20 j$ & $\mathrm{Me} / \mathrm{Me}$ & & n.a. & $20 t$ & $\mathrm{Et} / \mathrm{Et}$ & & n.a. \\
\hline
\end{tabular}




\begin{tabular}{|l|l|l|l|l|l|l|}
\hline $20 u$ & Et/Et & n.a. & & & \\
& & & & & & \\
\hline
\end{tabular}

Table 2: Screening data for autophagy inhibition for compounds 21a - 21v. Data were determined with $\mathrm{n}=3$. n.a. $=$ not active.

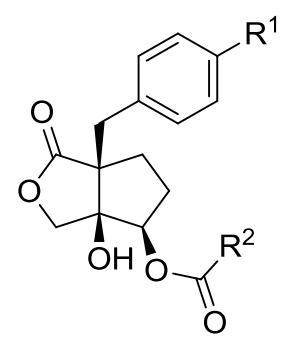

\begin{tabular}{|c|c|c|c|c|c|c|c|}
\hline No. & $\mathbf{R}^{1}$ & $\mathbf{R}^{2}$ & $\begin{array}{c}\mathrm{IC}_{\mathbf{5 0}} \\
{[\boldsymbol{\mu M}]}\end{array}$ & No. & $\mathbf{R}^{1}$ & $\mathbf{R}^{2}$ & $\begin{array}{c}\mathrm{IC}_{\mathbf{5 0}} \\
{[\boldsymbol{\mu M}]}\end{array}$ \\
\hline $21 a$ & $\mathrm{H}$ & & n.a. & 211 & $\mathrm{~F}$ & & $6.1 \pm 3.7$ \\
\hline $21 b$ & $\mathrm{H}$ & & n.a. & $21 \mathrm{~m}$ & $\mathrm{~F}$ & & $8.3 \pm 0.7$ \\
\hline 21c & $\mathrm{H}$ & & n.a. & $21 n$ & $\mathrm{OMe}$ & & n.a. \\
\hline 21d & $\mathrm{H}$ & & n.a. & 210 & $\mathrm{OMe}$ & & n.a. \\
\hline 21e & $\mathrm{F}$ & & n.a. & 21p & $\mathrm{OMe}$ & & n.a. \\
\hline $21 f$ & $\mathrm{~F}$ & & $8.8 \pm 0.8$ & $21 q$ & $\mathrm{OMe}$ & & $11.1 \pm 0.9$ \\
\hline $21 g$ & $\mathrm{~F}$ & & n.a. & $21 r$ & $\mathrm{OMe}$ & & $>30 \mu \mathrm{M}$ \\
\hline $21 \mathrm{~h}$ & $\mathrm{~F}$ & & $4.8 \pm 0.7$ & $21 s$ & $\mathrm{OMe}$ & & $4.7 \pm 0.3$ \\
\hline $21 \mathrm{i}$ & $\mathrm{F}$ & & $7.2 \pm 1.4$ & $21 t$ & $\mathrm{OMe}$ & & $5.0 \pm 2.1$ \\
\hline
\end{tabular}




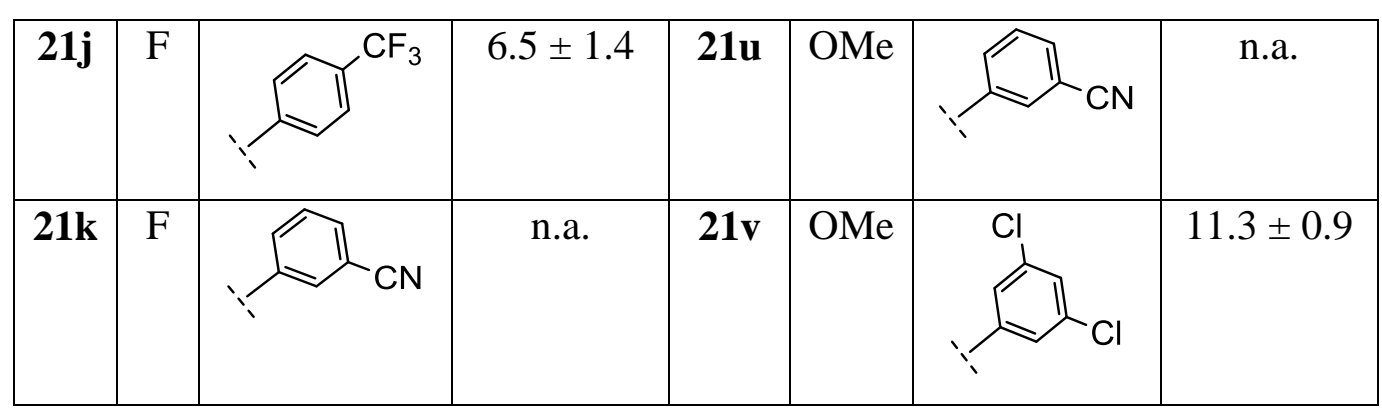


${ }^{1} \mathrm{H}$ NMR of 9a in DMSO-D 6 (400 MHz)

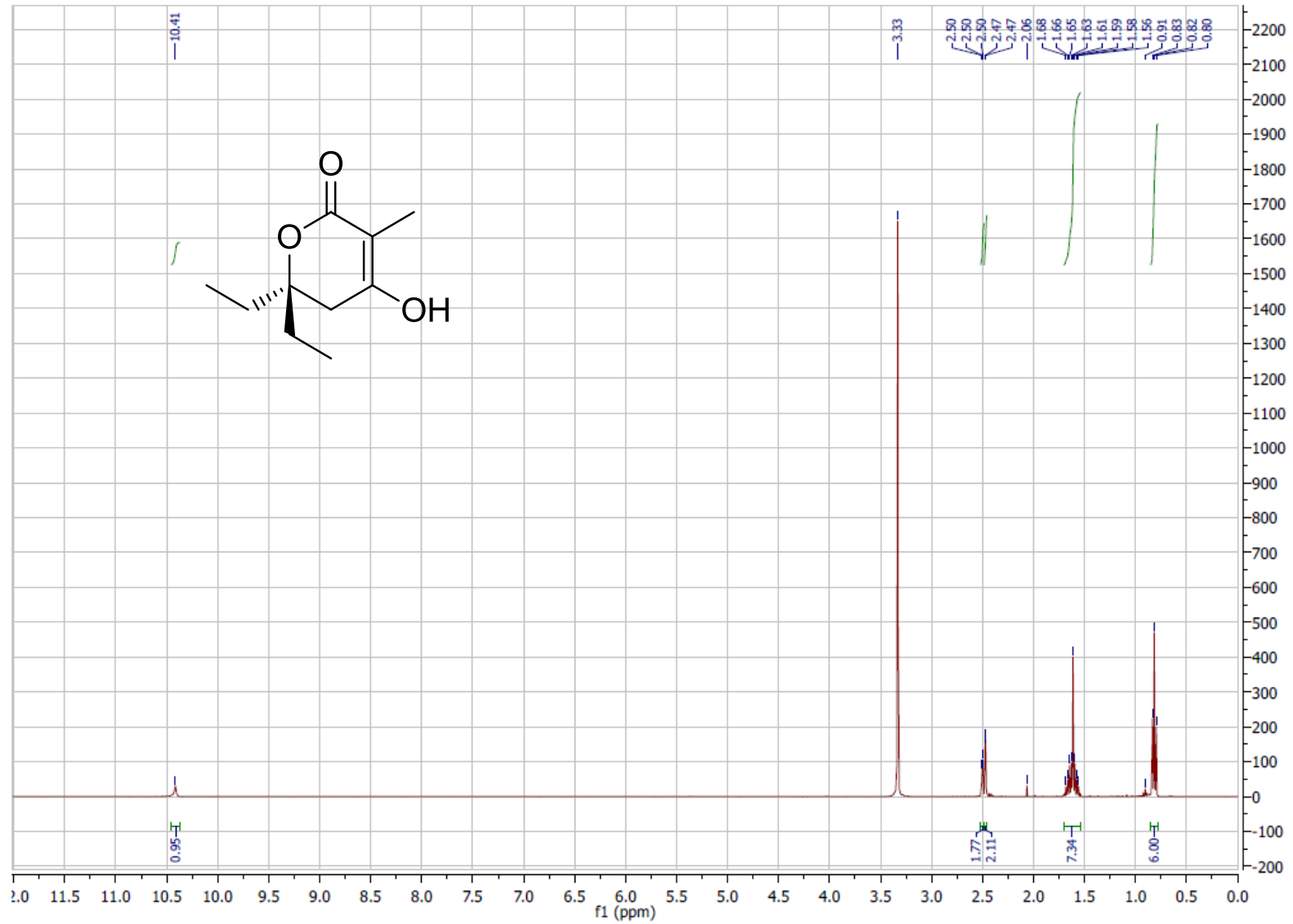

${ }^{13} \mathrm{C}$ NMR of 9a in DMSO-D 6 (126 MHz)

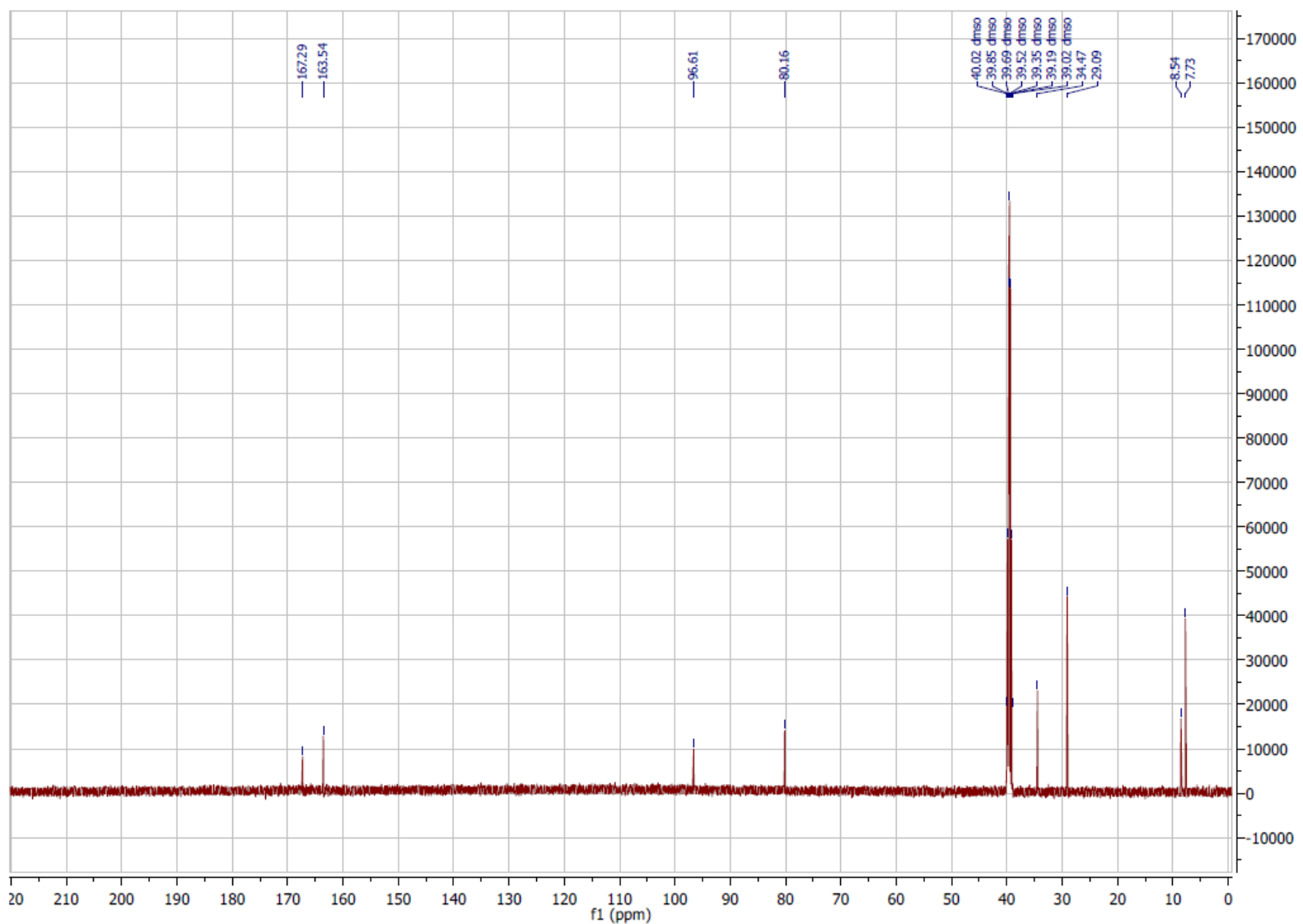


${ }^{1} \mathrm{H}$ NMR of 9b in DMSO-D $(500 \mathrm{MHz})$

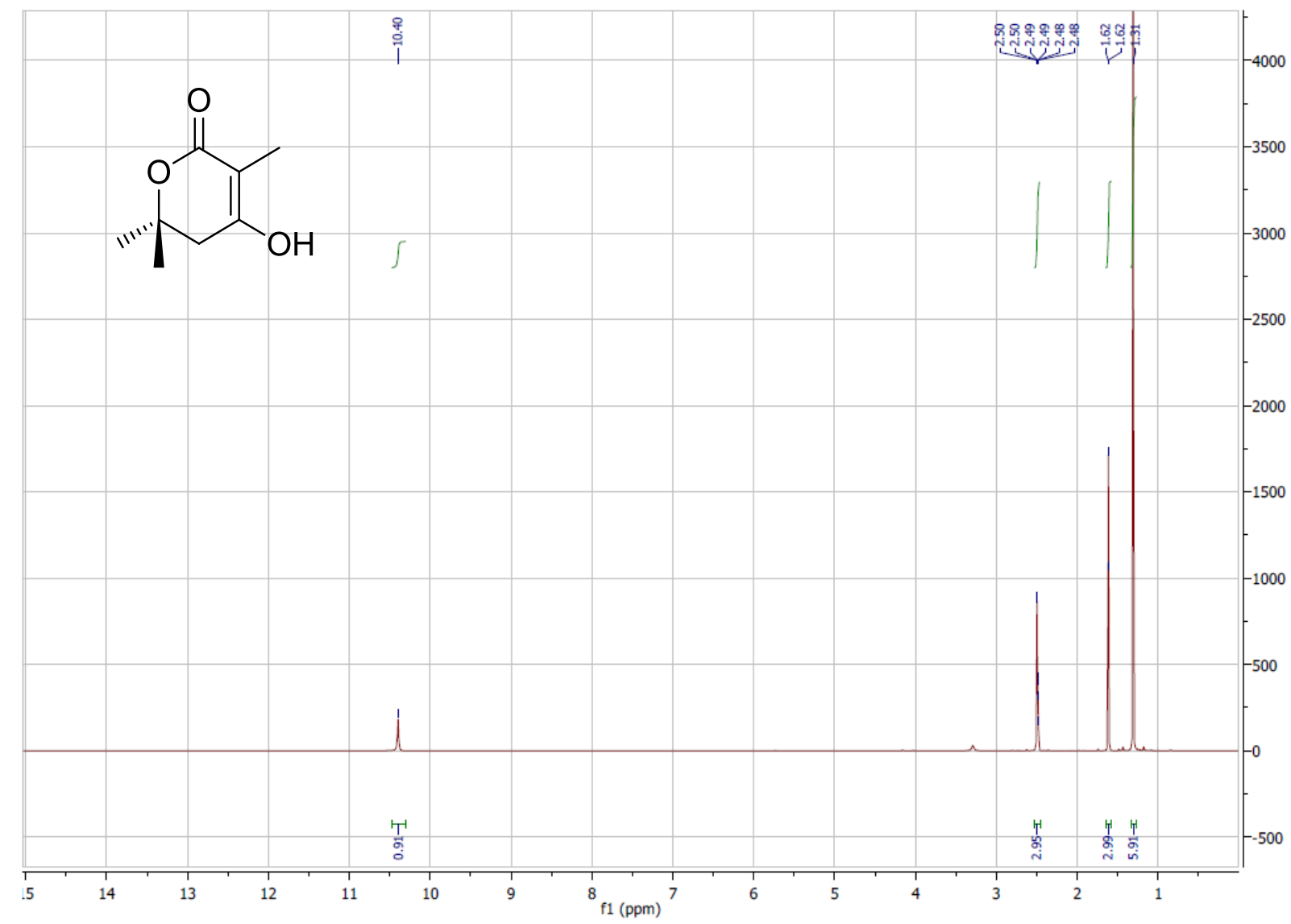

${ }^{13} \mathrm{C}$ NMR of 9b in DMSO-D 6 (126 MHz)

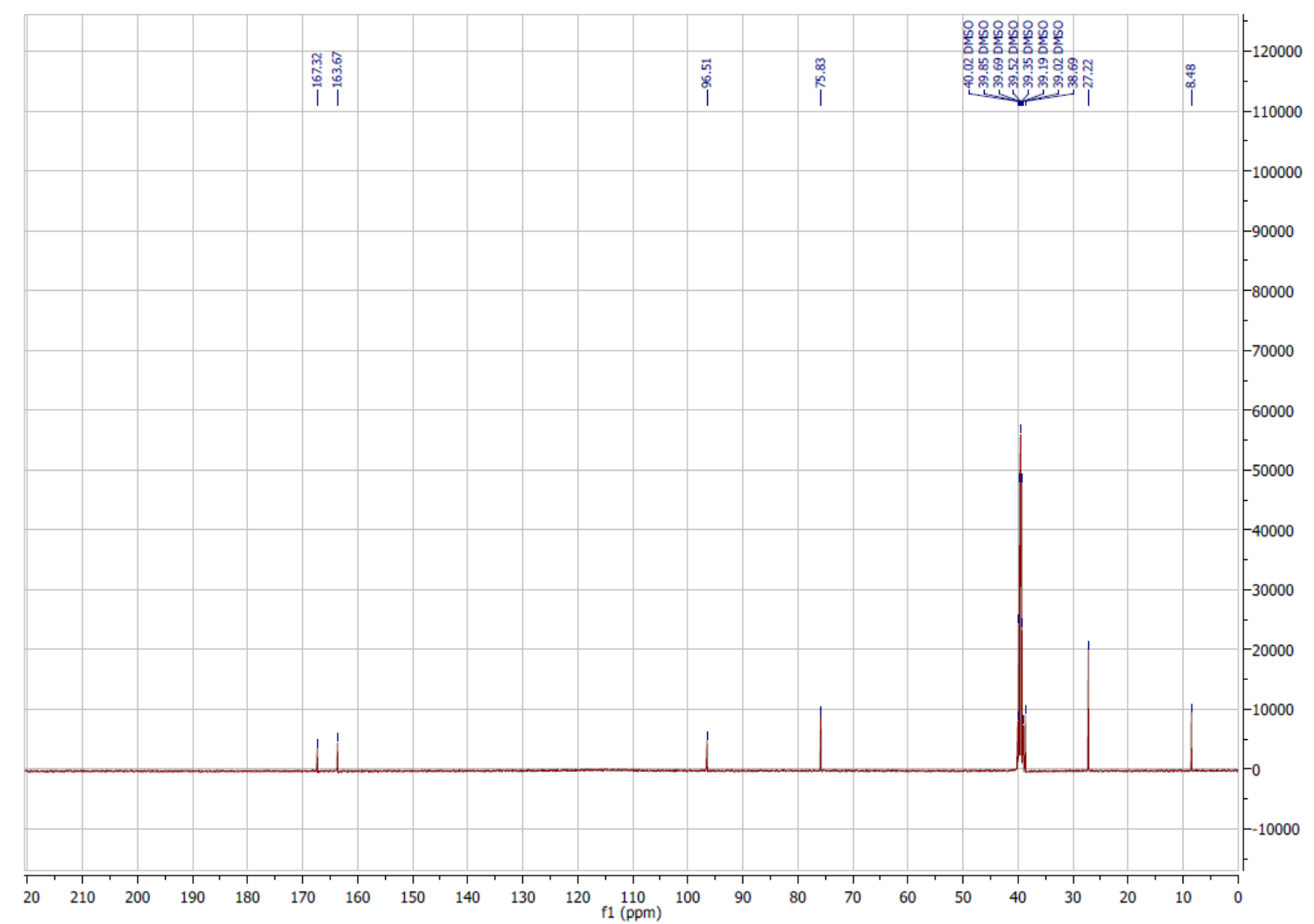


${ }^{1} \mathrm{H}$ NMR of 16a in DMSO-D ${ }_{6}(400 \mathrm{MHz})$

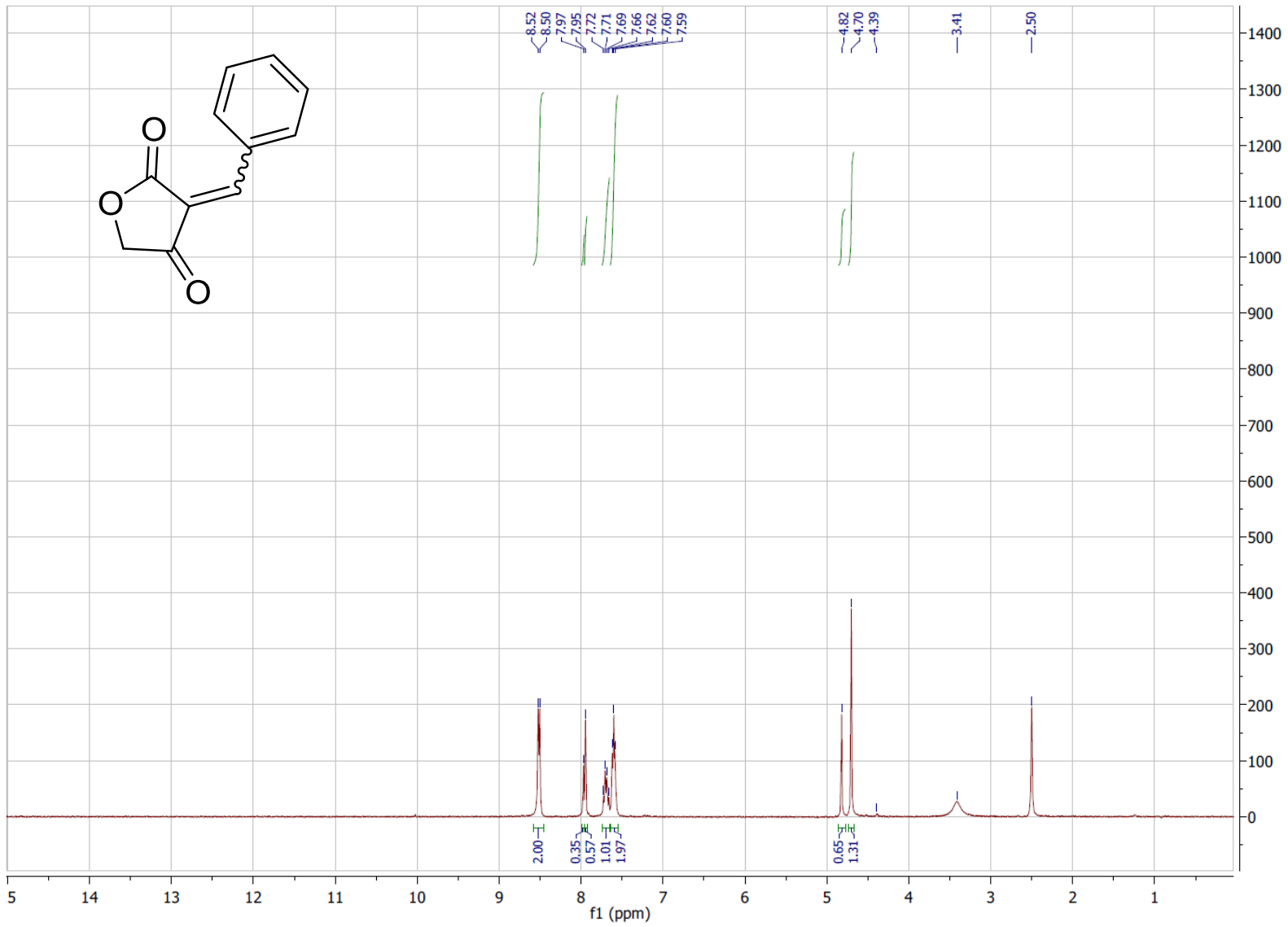

${ }^{13} \mathrm{C}$ NMR of 16a in DMSO-D ${ }_{6}(101 \mathrm{MHz})$

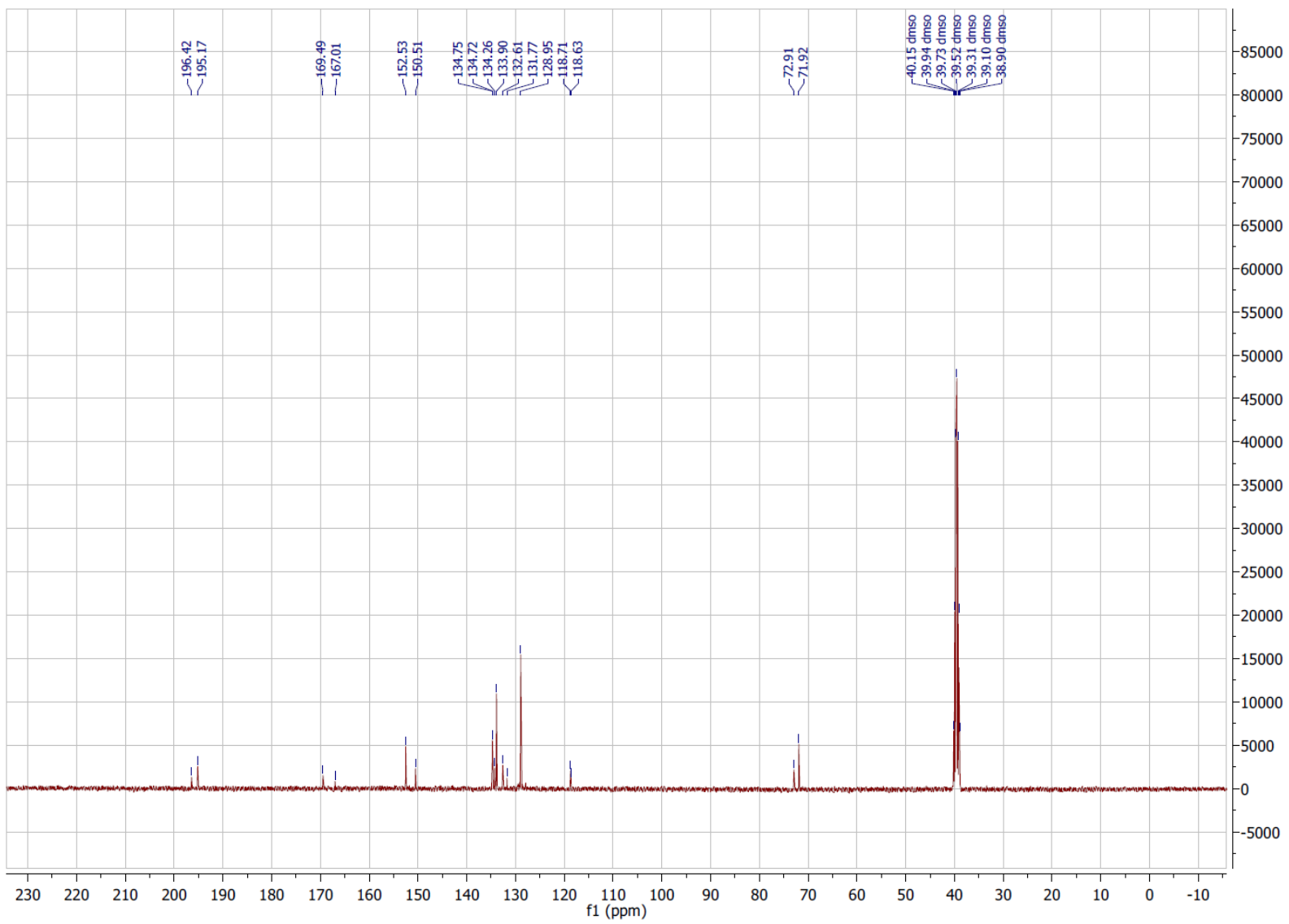


${ }^{1} \mathrm{H}$ NMR of $\mathbf{1 6 b}$ in DMSO-D 6 (500 MHz)

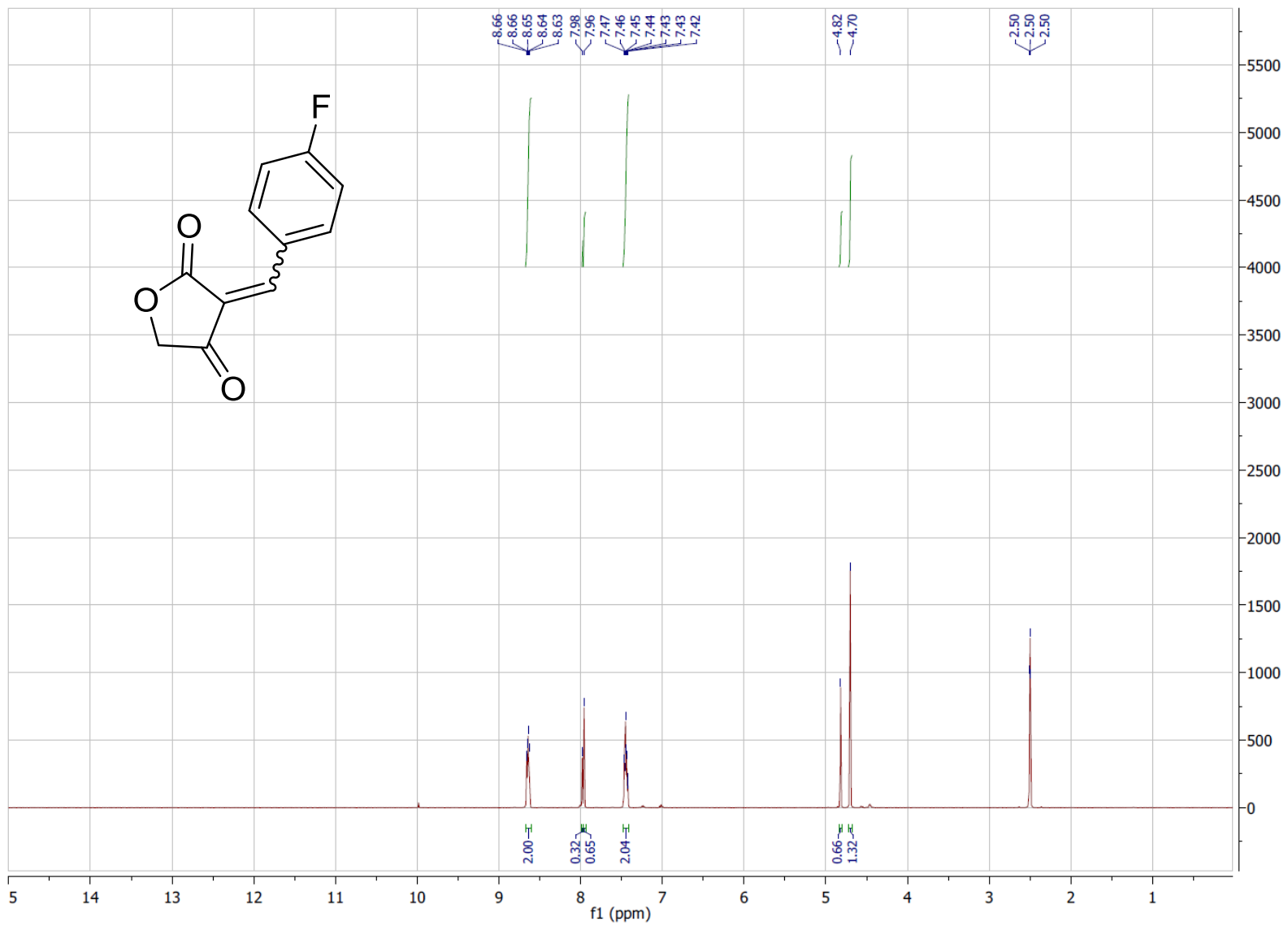

${ }^{13} \mathrm{C}$ NMR of $\mathbf{1 6 b}$ in DMSO-D 6 (126 MHz)

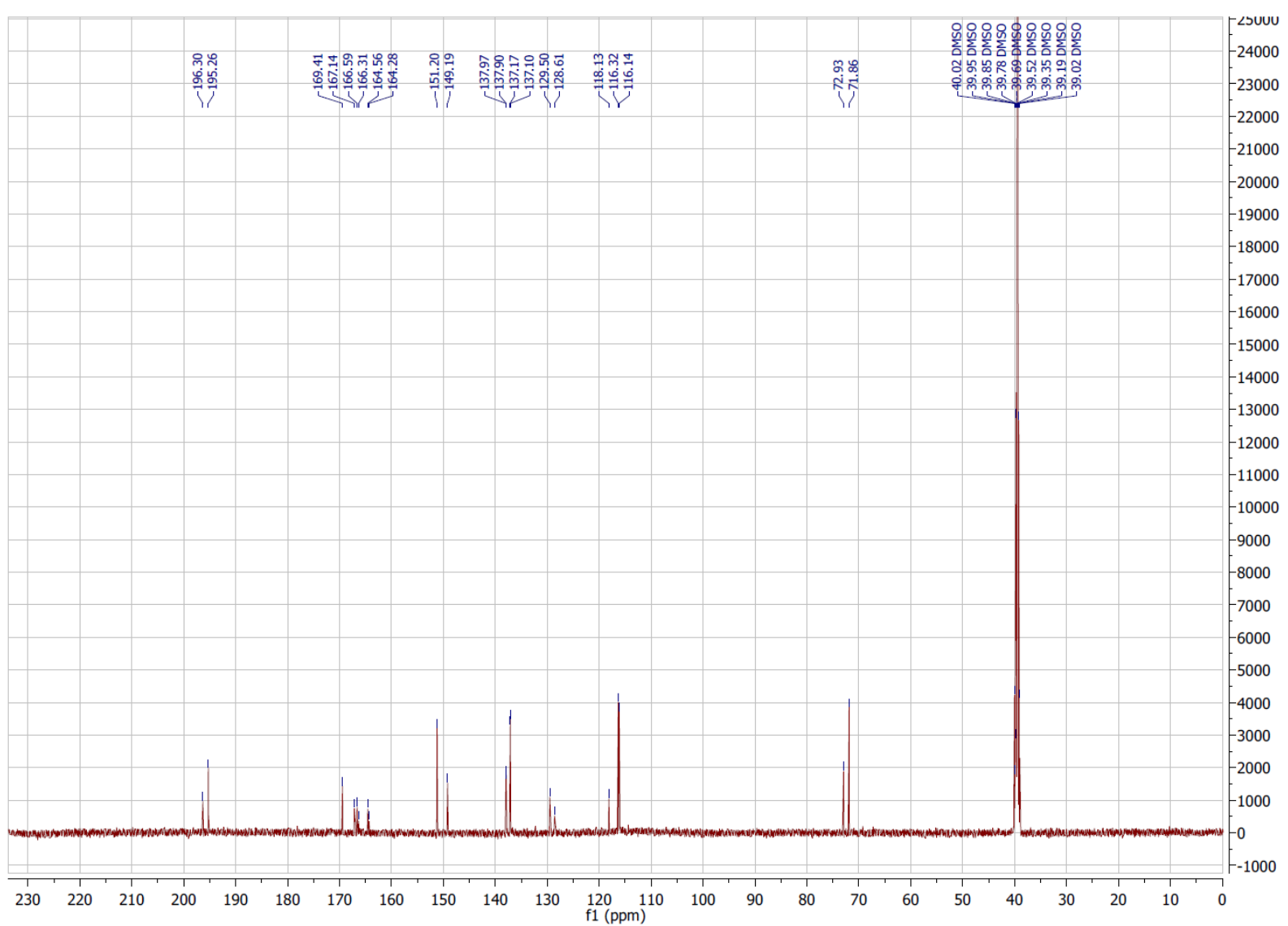


${ }^{1} \mathrm{H}$ NMR of 16c in DMSO-D $(500 \mathrm{MHz})$

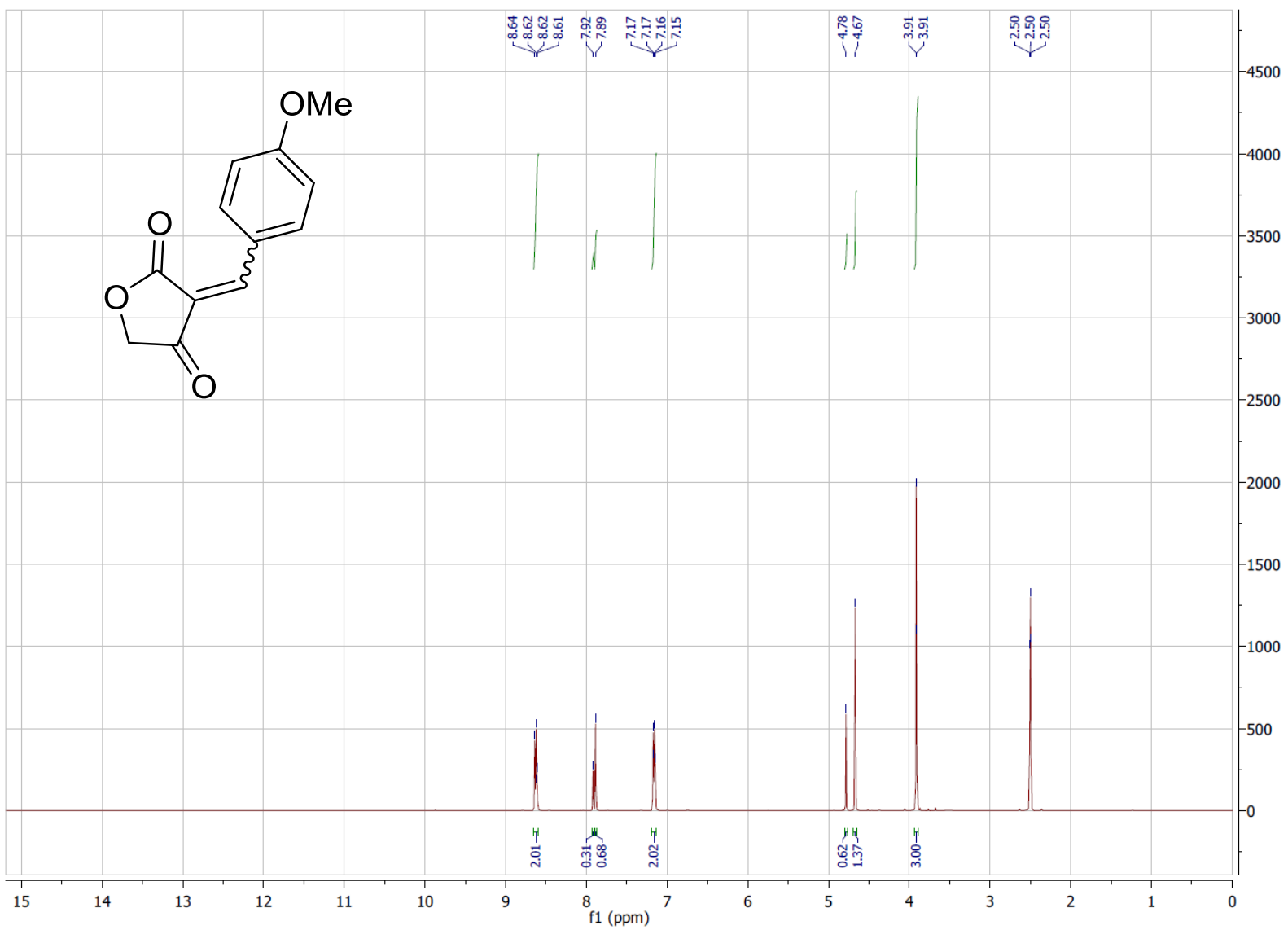

${ }^{13} \mathrm{C}$ NMR of 16c in DMSO-D $6(126 \mathrm{MHz})$

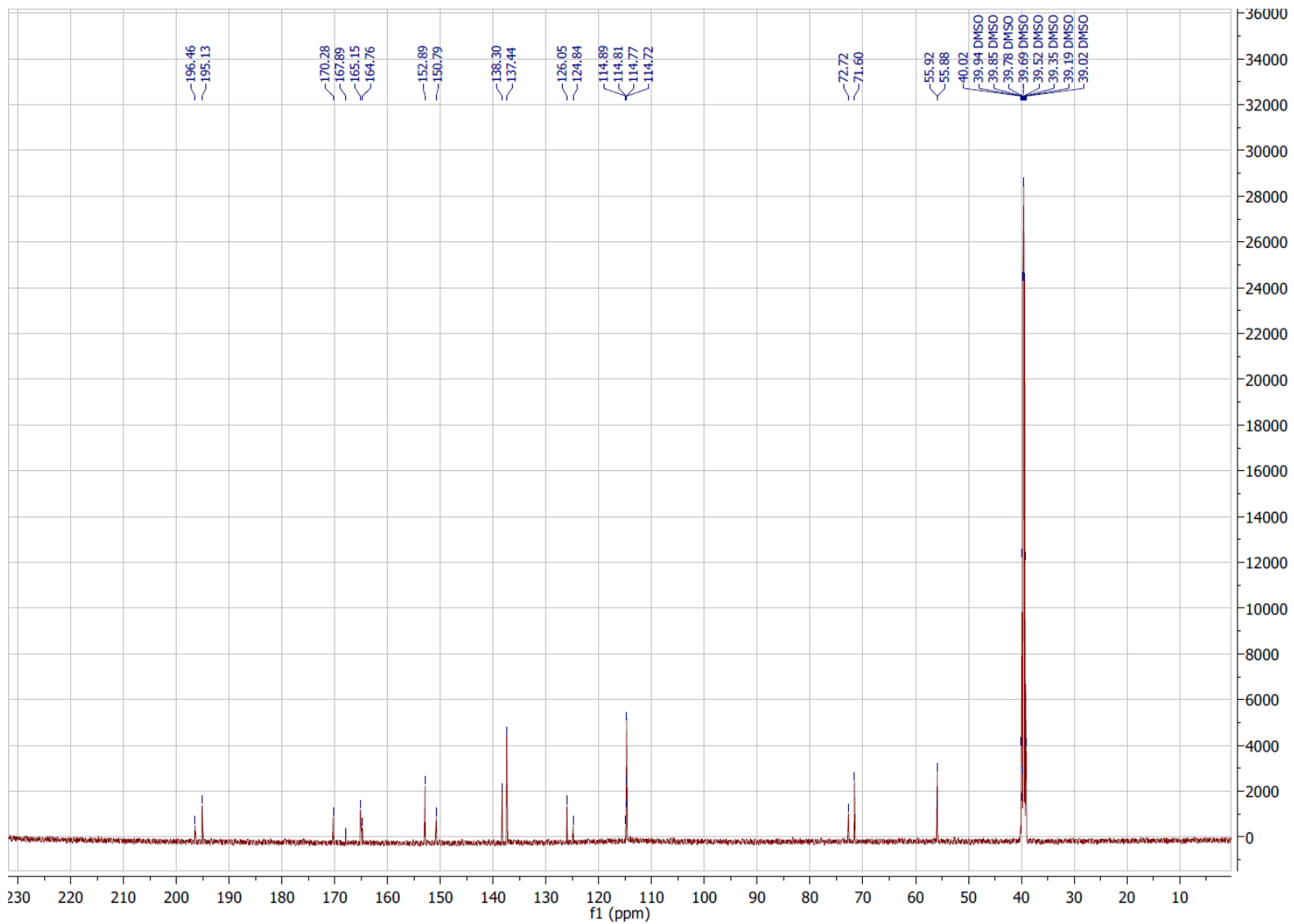


${ }^{1} \mathrm{H}$ NMR of 17a in DMSO-D 6 (500 MHz)

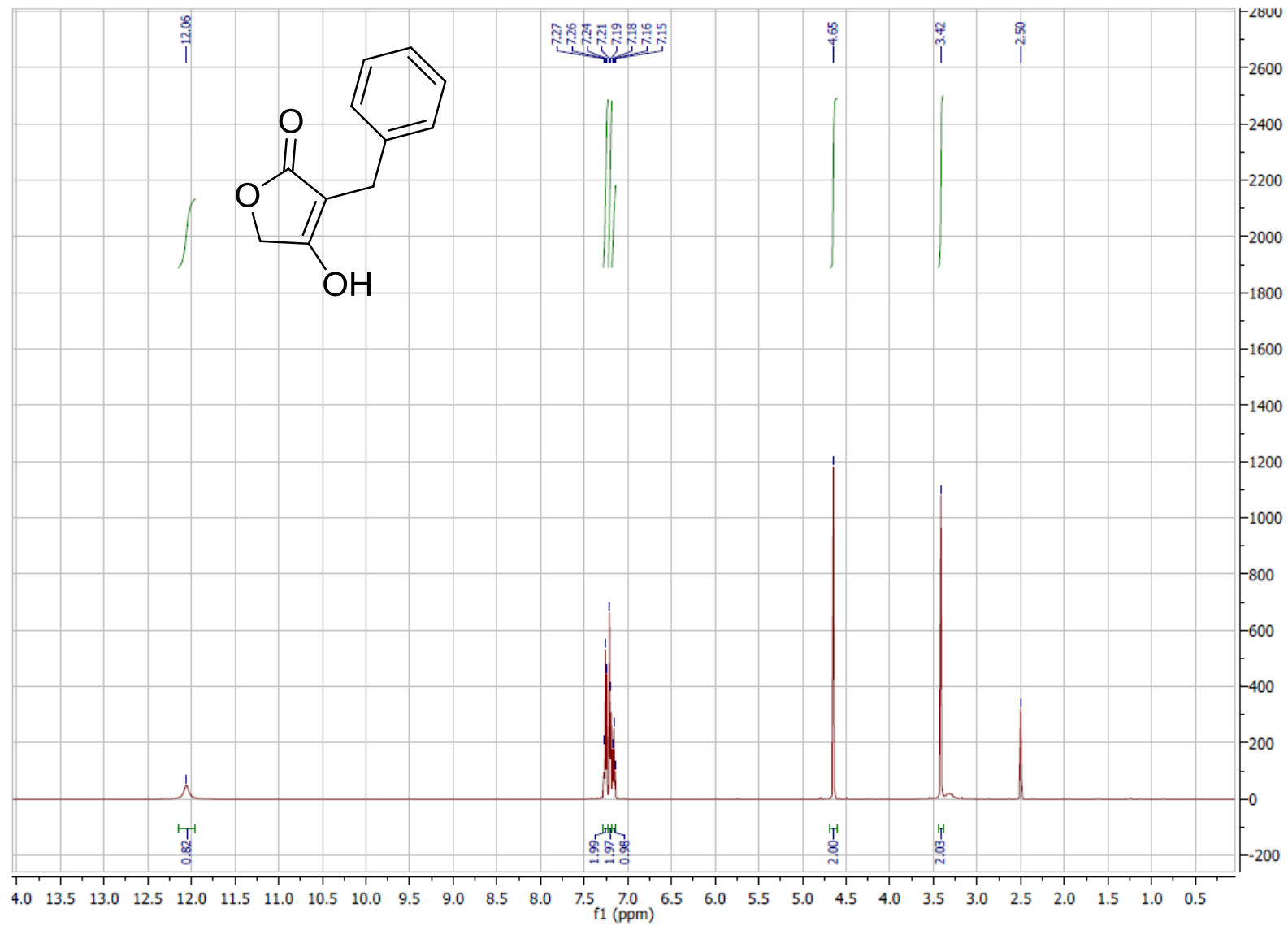

${ }^{13} \mathrm{C}$ NMR of 17a in DMSO-D 6 (126 MHz)

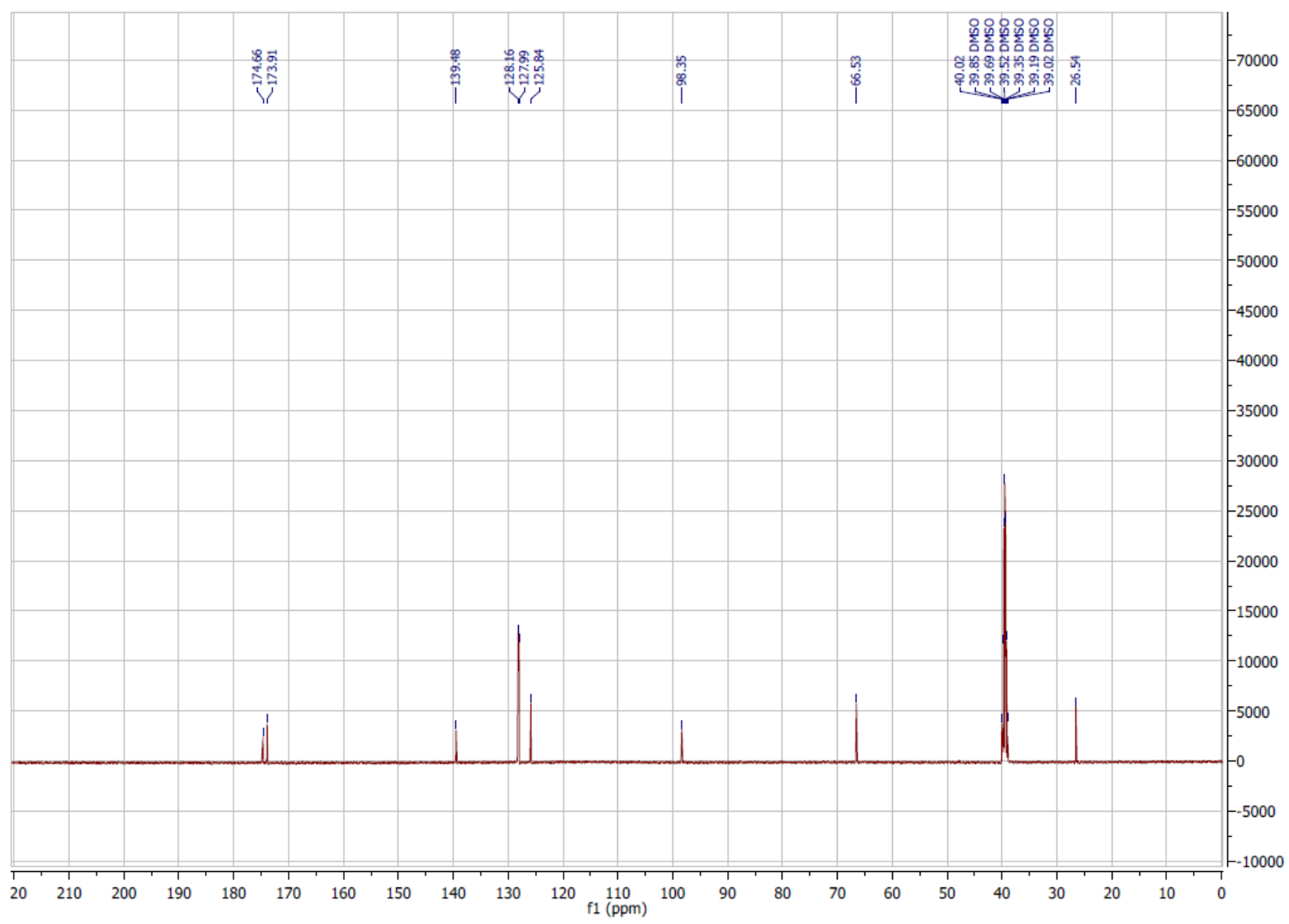


${ }^{1} \mathrm{H}$ NMR of $\mathbf{1 7 b}$ in DMSO-D 6 (400 MHz)

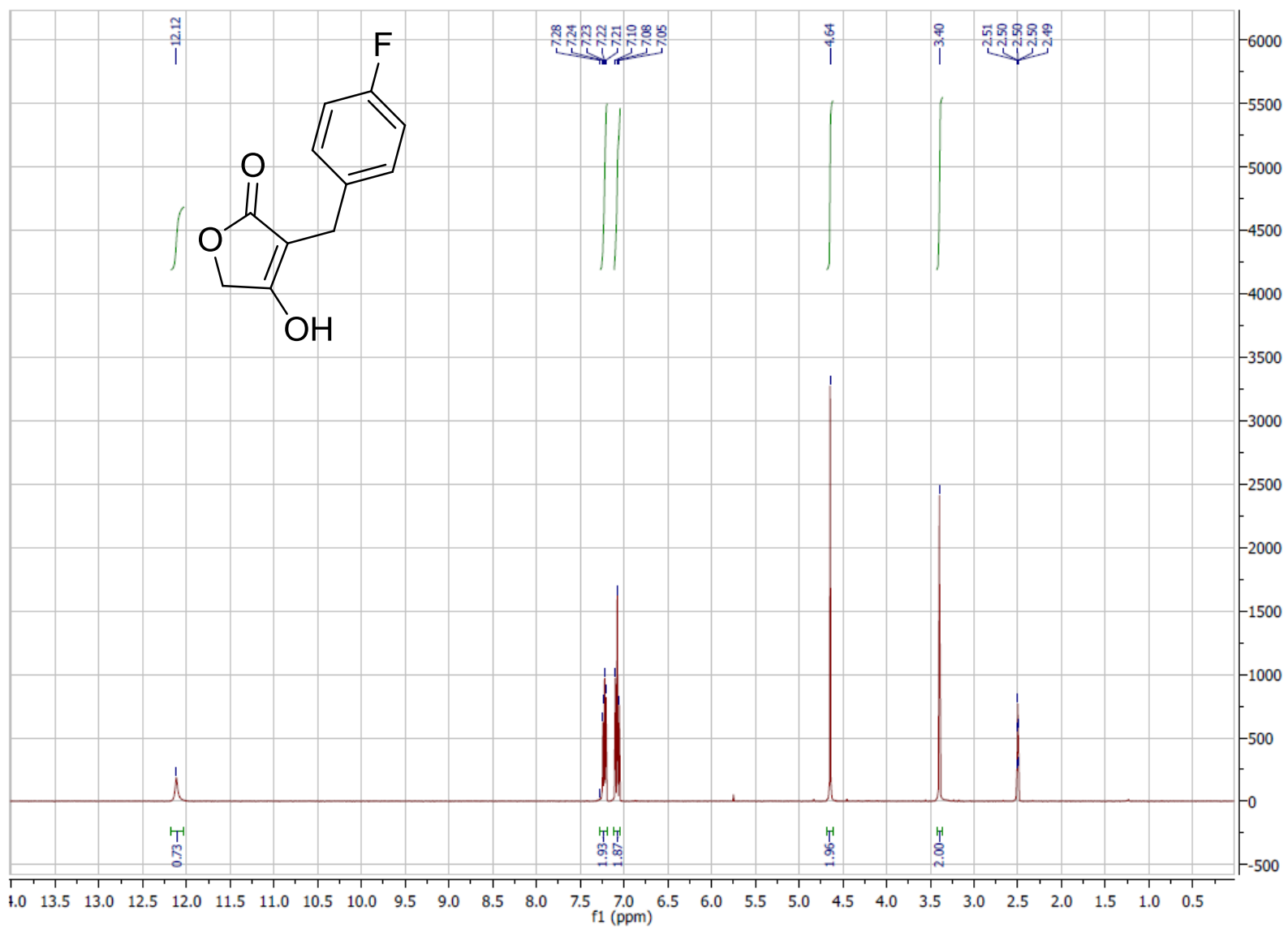

${ }^{13} \mathrm{C}$ NMR of 17b in DMSO-D 6 (101 MHz)

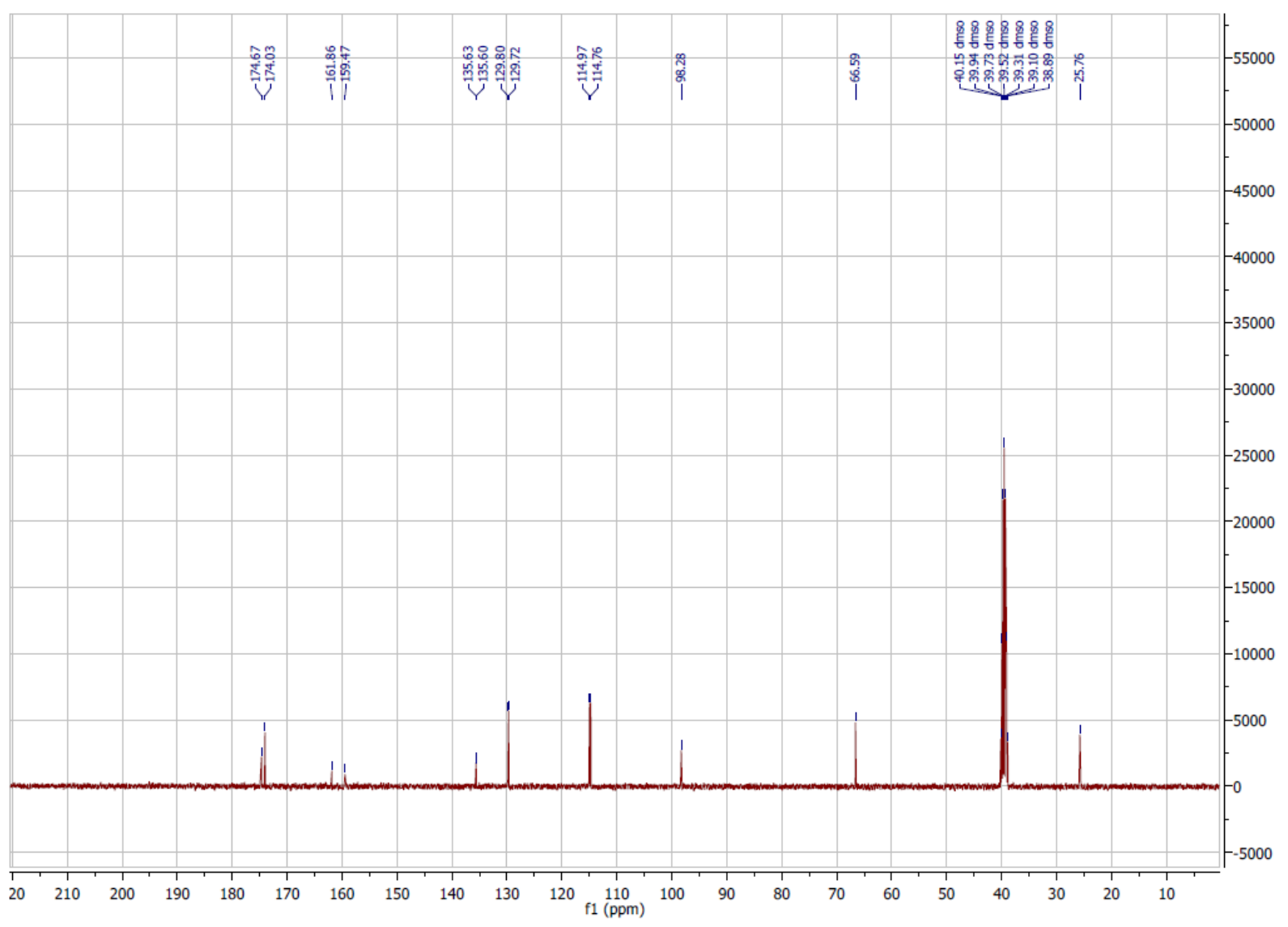


${ }^{1} \mathrm{H}$ NMR of $17 \mathrm{c}$ in DMSO-D 6 (400 MHz)

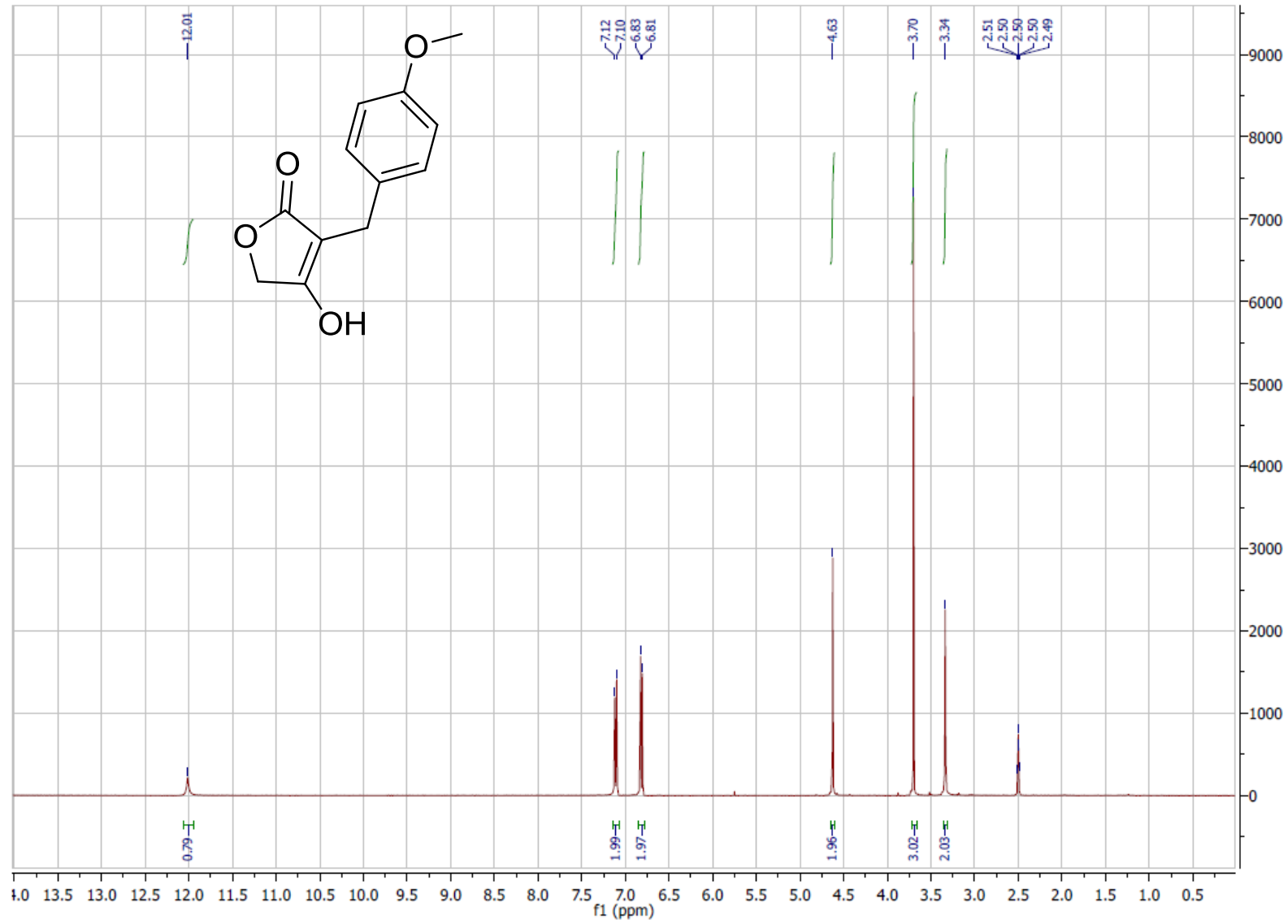

${ }^{13} \mathrm{C}$ NMR of 17c in DMSO-D $(101 \mathrm{MHz})$

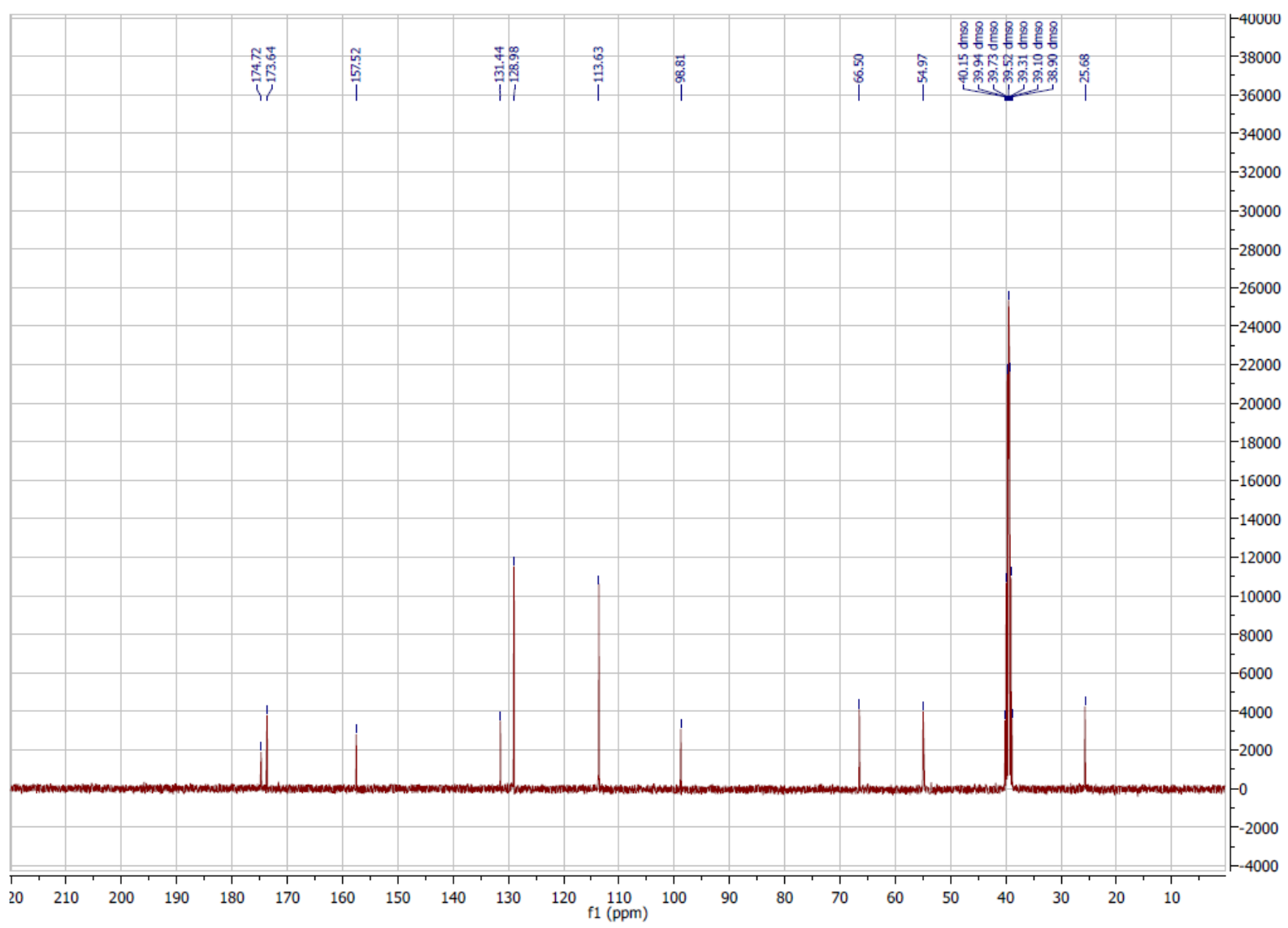


${ }^{1} \mathrm{H}$ NMR of 13a in $\mathrm{CDCl}_{3}(400 \mathrm{MHz})$

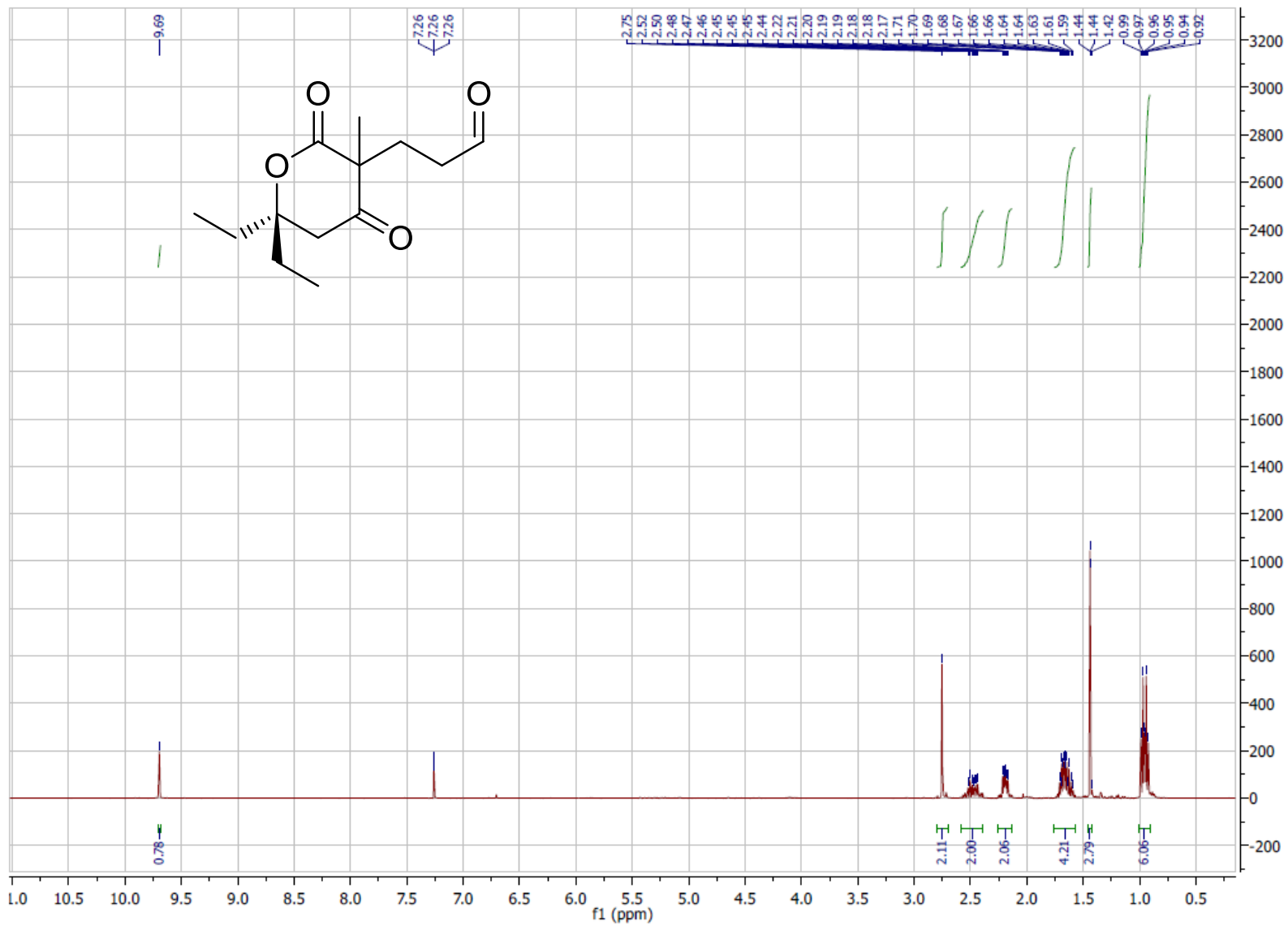

${ }^{13} \mathrm{C}$ NMR of 13a in $\mathrm{CDCl}_{3}(101 \mathrm{MHz})$

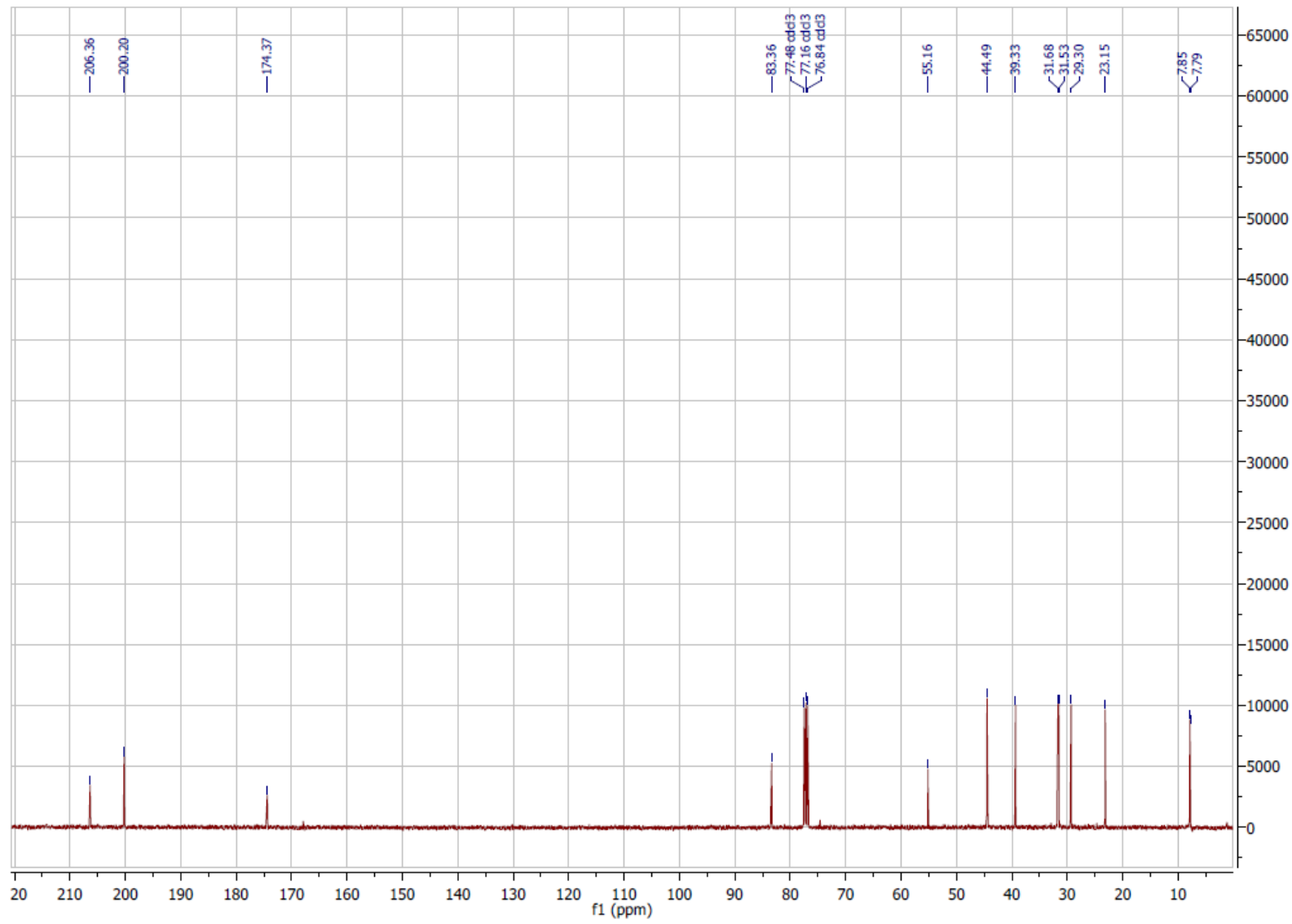


${ }^{1} \mathrm{H} \mathrm{NMR}$ of $\mathbf{1 3 b}$ in $\mathrm{CDCl}_{3}(500 \mathrm{MHz})$

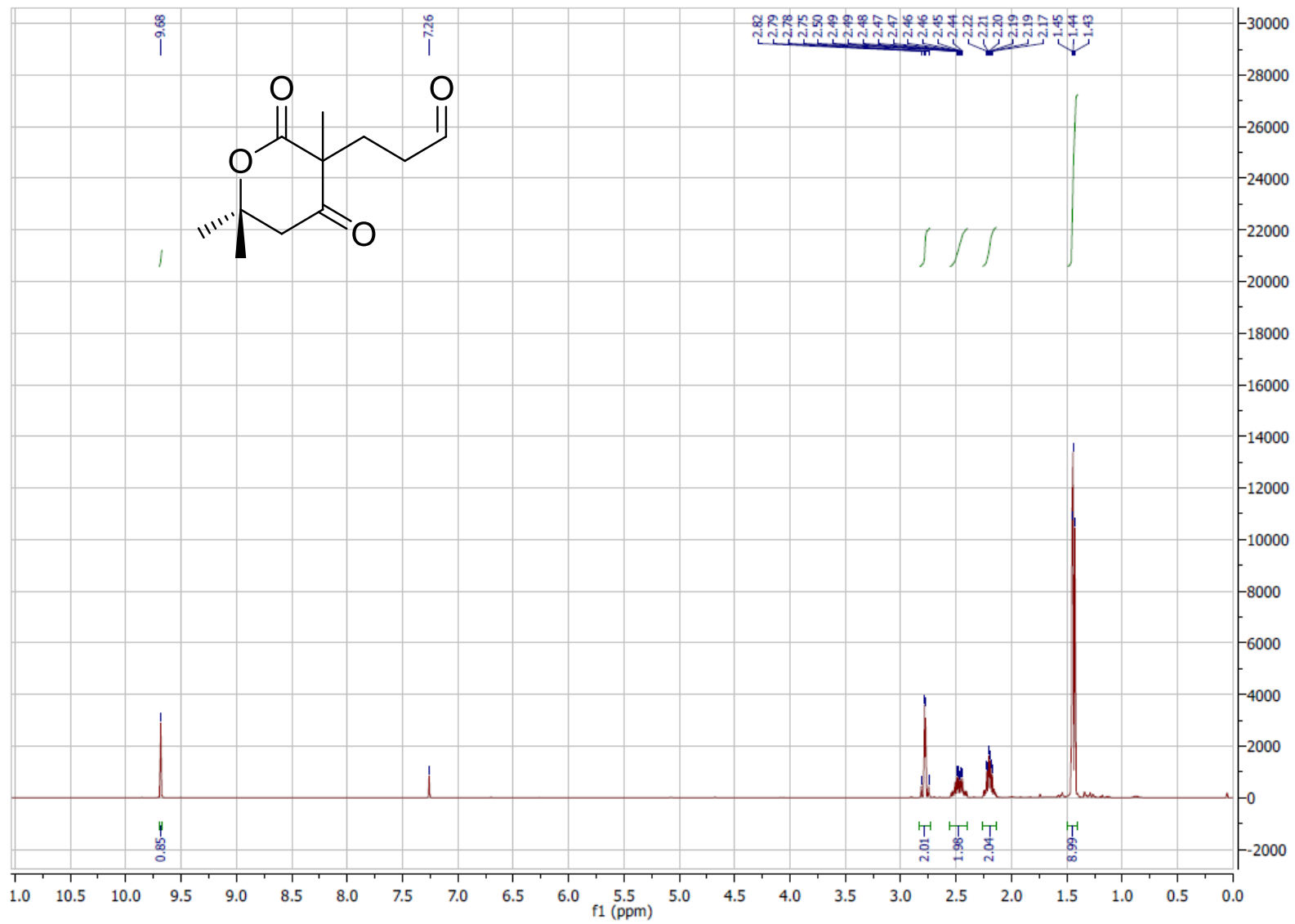

${ }^{13} \mathrm{C}$ NMR of $\mathbf{1 3 b}$ in $\mathrm{CDCl}_{3}(126 \mathrm{MHz})$

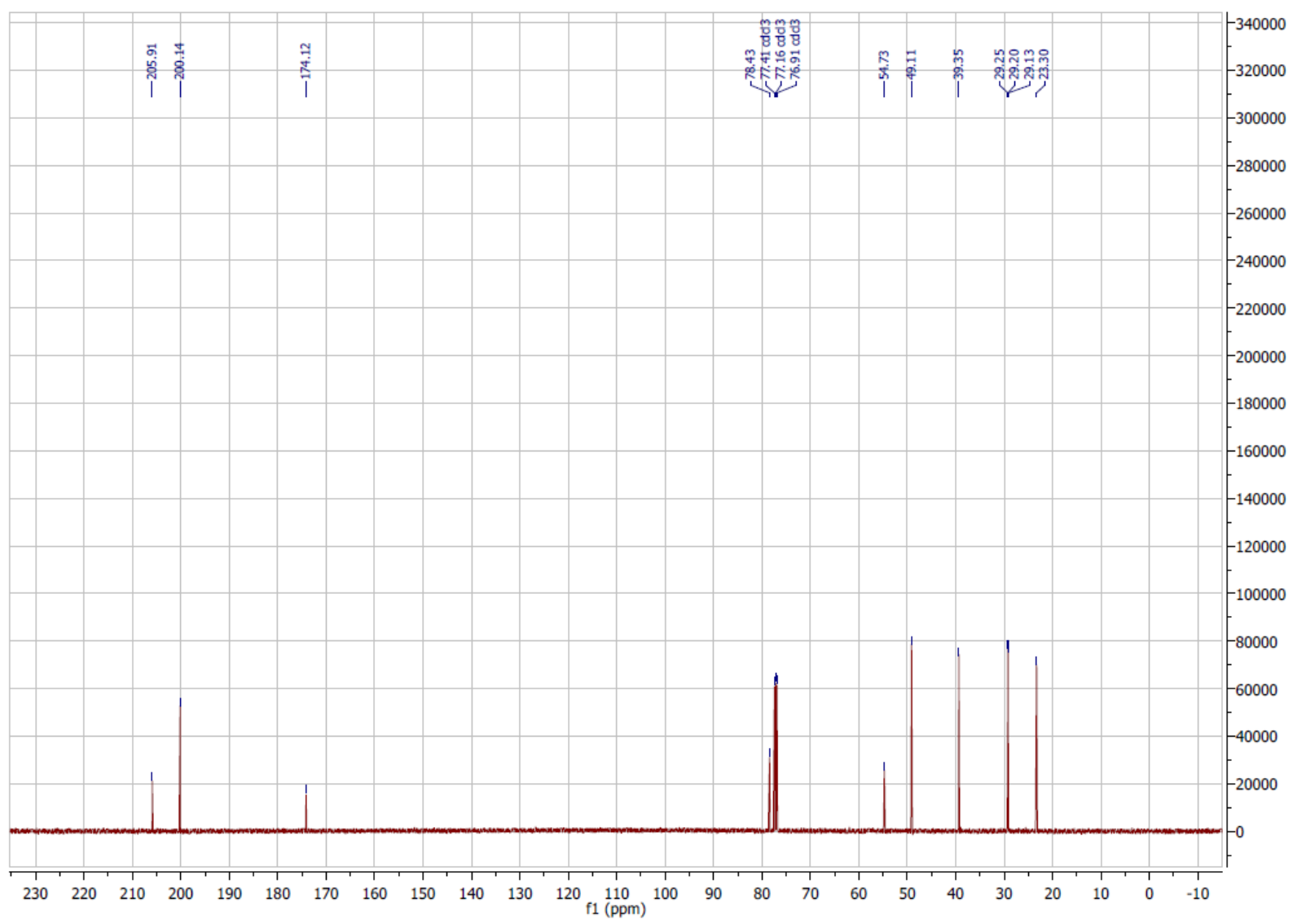


${ }^{1} \mathrm{H}$ NMR of $13 \mathrm{c}$ in $\mathrm{CDCl}_{3}(500 \mathrm{MHz})$

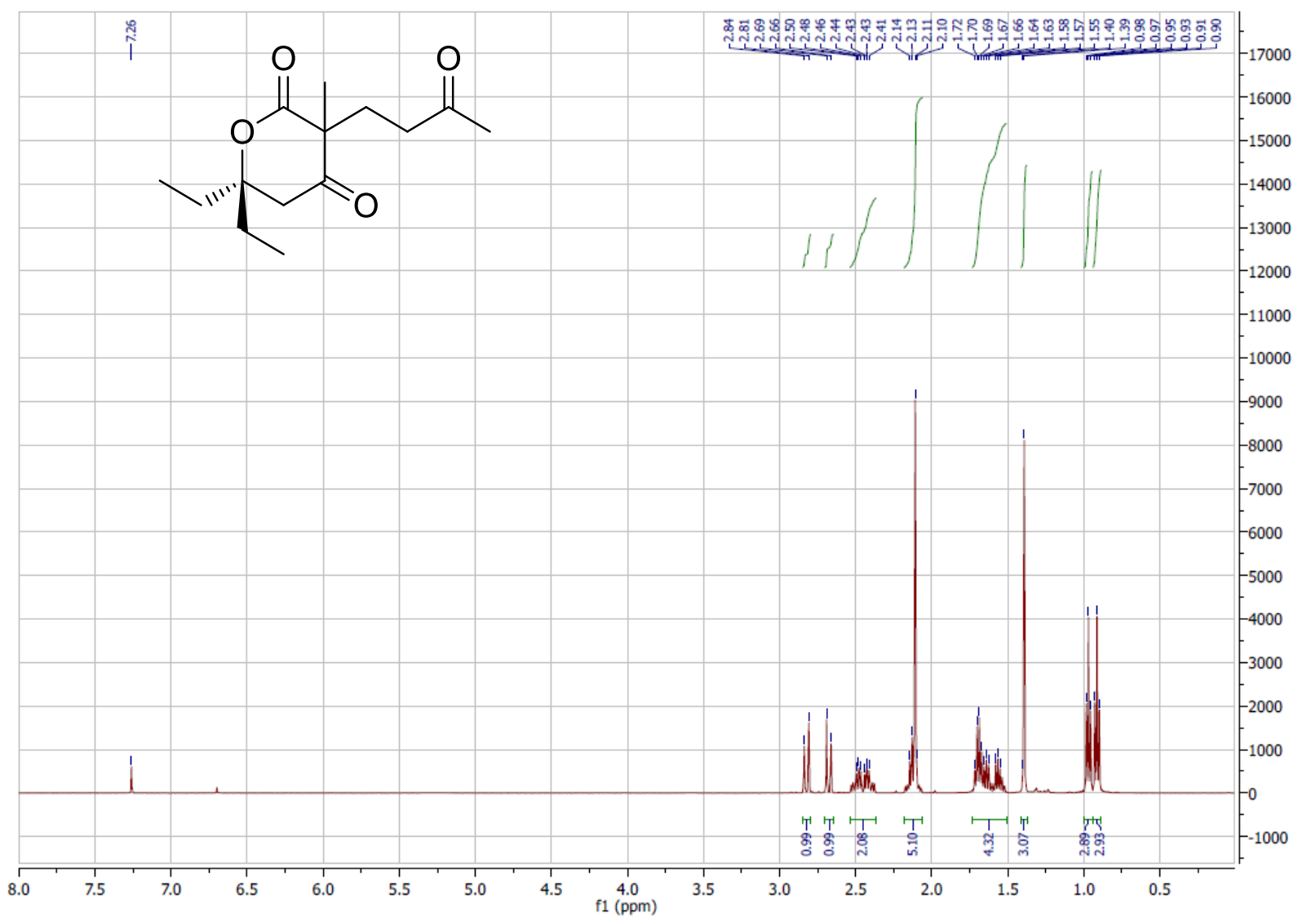

${ }^{13} \mathrm{C}$ NMR of $13 \mathrm{c}$ in $\mathrm{CDCl}_{3}(126 \mathrm{MHz})$

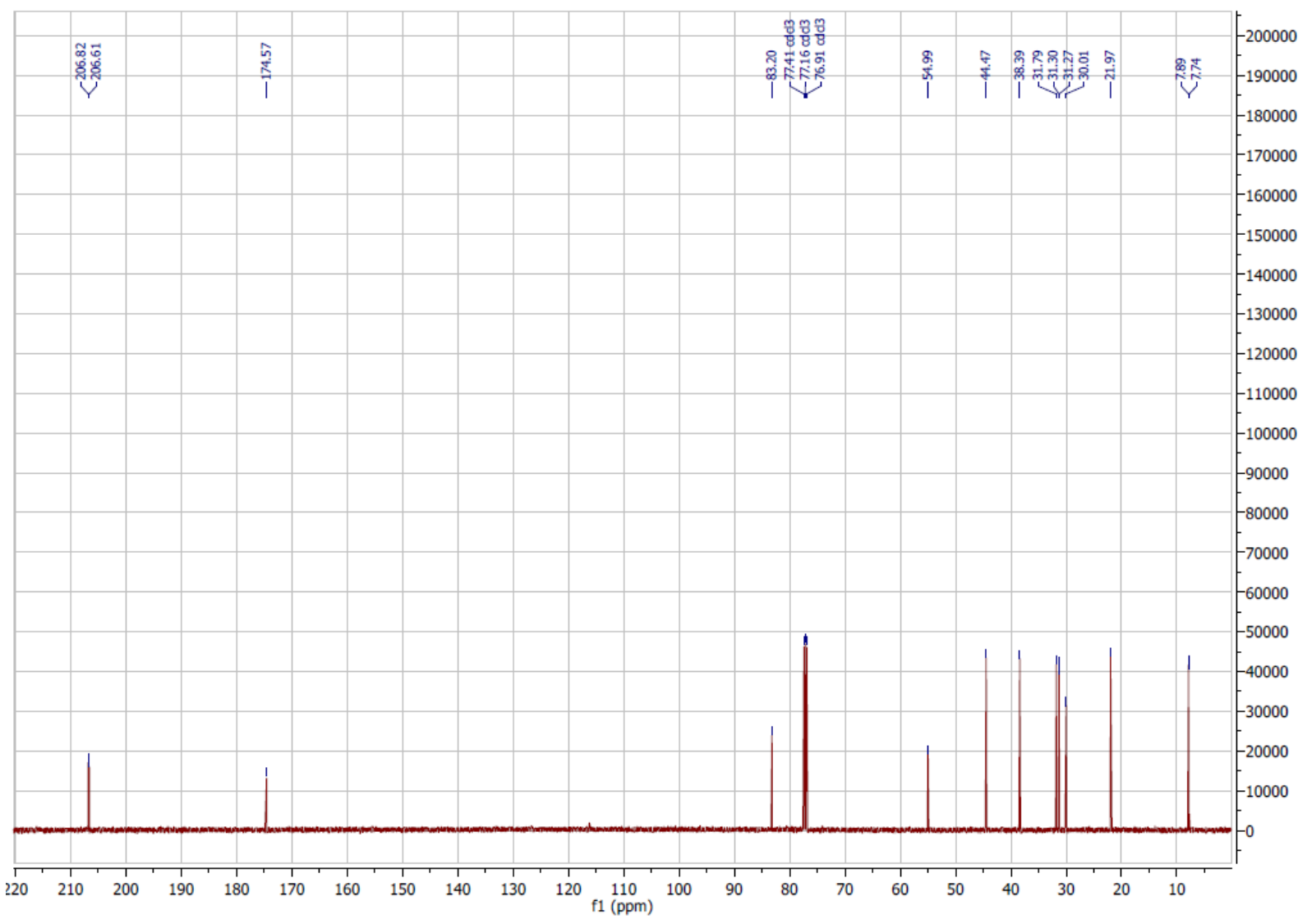


${ }^{1} \mathrm{H}$ NMR of $\mathbf{1 3 d}$ in $\mathrm{CDCl}_{3}(500 \mathrm{MHz})$

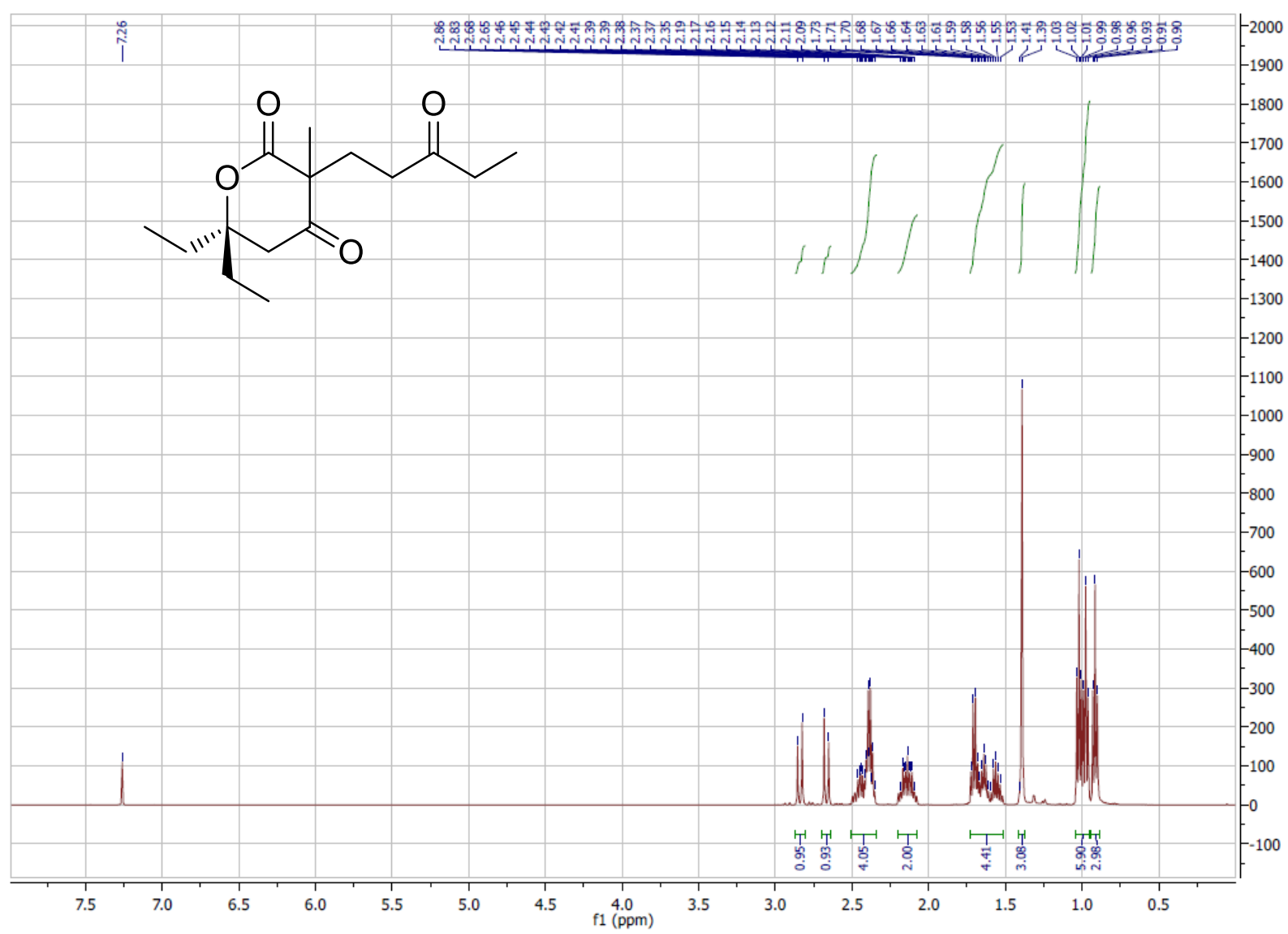

${ }^{13} \mathrm{C}$ NMR of $\mathbf{1 3 d}$ in $\mathrm{CDCl}_{3}(126 \mathrm{MHz})$

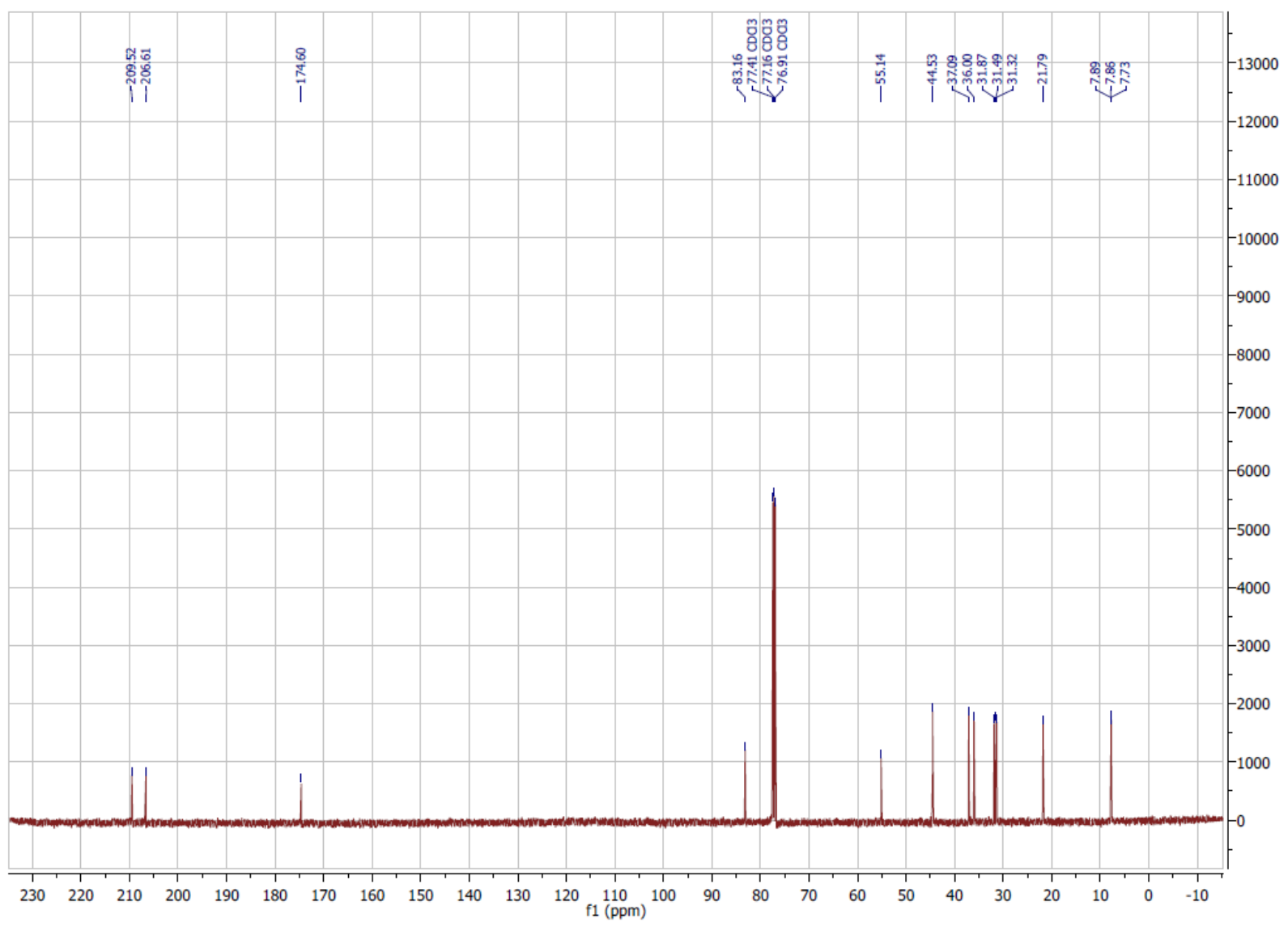


${ }^{1} \mathrm{H}$ NMR of 19a in $\mathrm{CDCl}_{3}(400 \mathrm{MHz})$

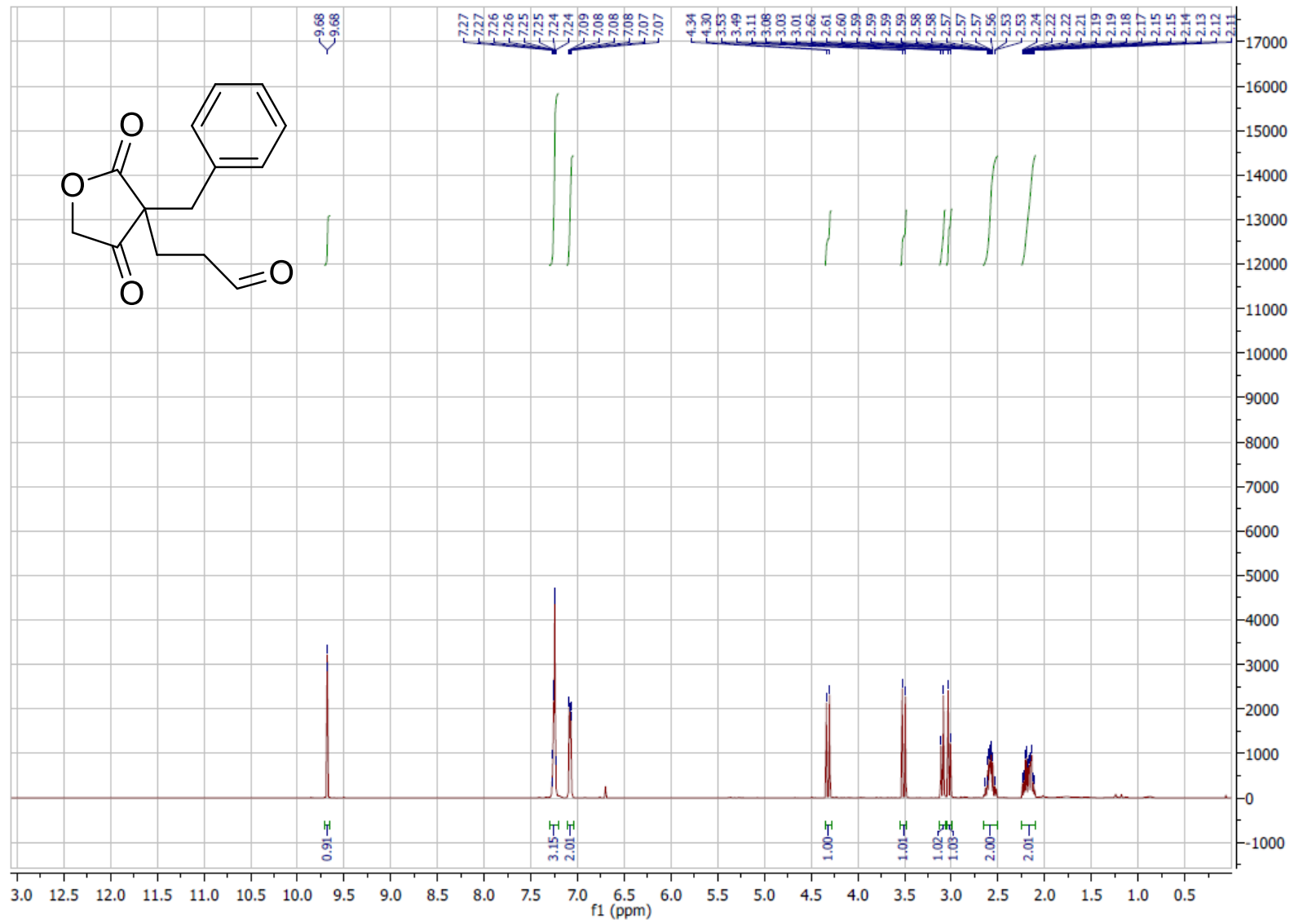

${ }^{13} \mathrm{C}$ NMR of 19a in $\mathrm{CDCl}_{3}(126 \mathrm{MHz})$

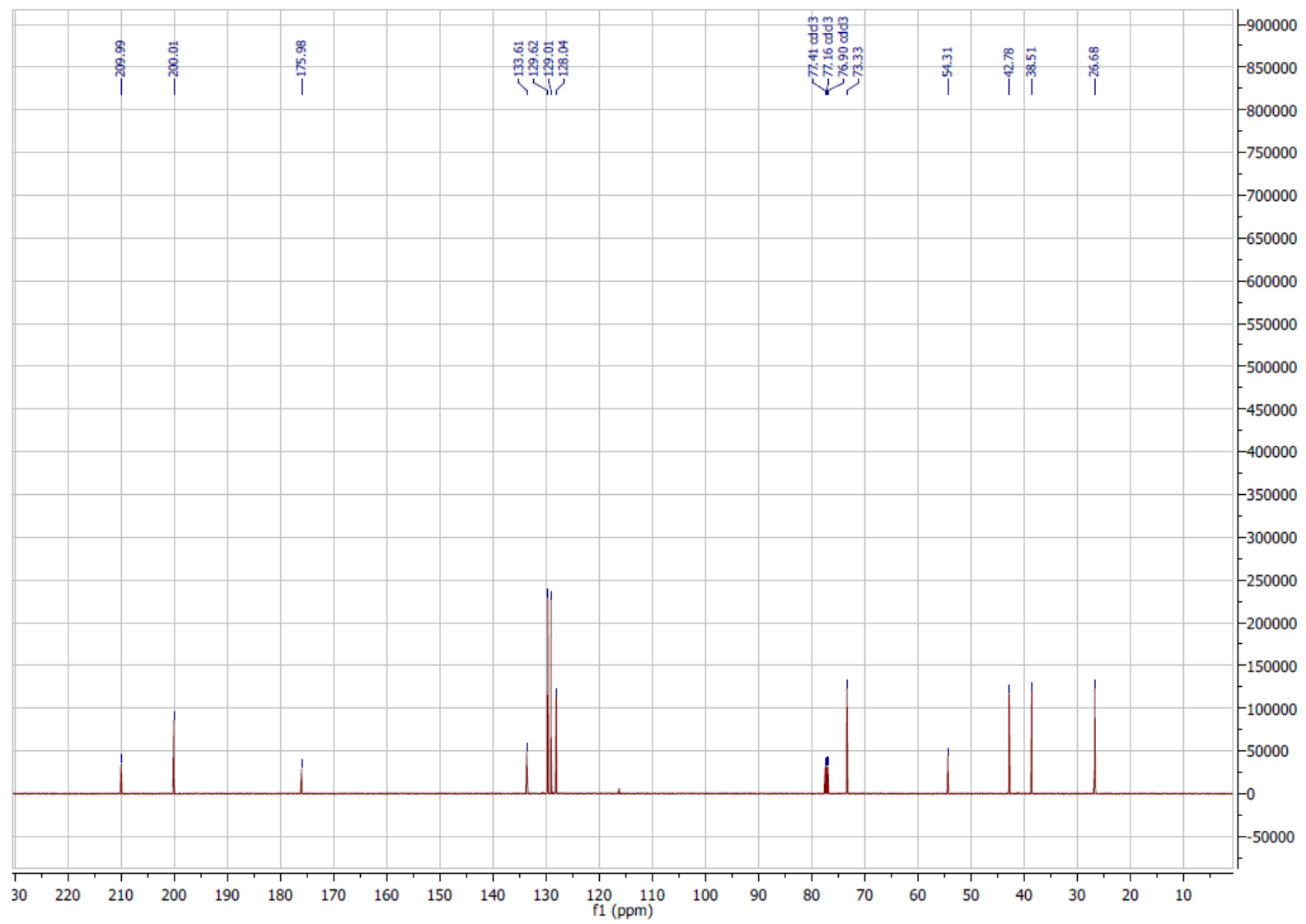


${ }^{1} \mathrm{H} \mathrm{NMR}$ of $\mathbf{1 9 b}$ in $\mathrm{CDCl}_{3}(400 \mathrm{MHz})$

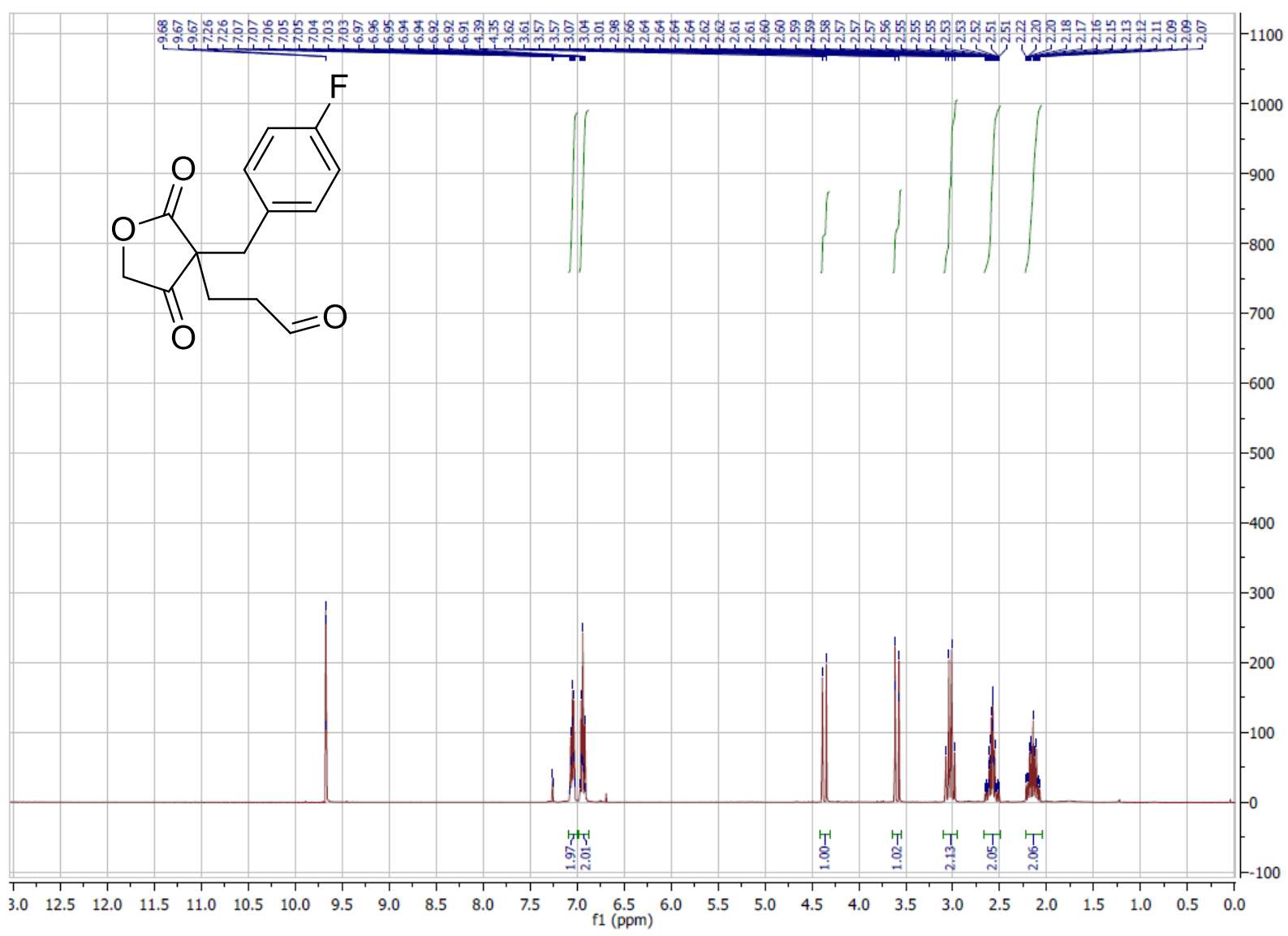

${ }^{13} \mathrm{C}$ NMR of $\mathbf{1 9 b}$ in $\mathrm{CDCl}_{3}(101 \mathrm{MHz})$

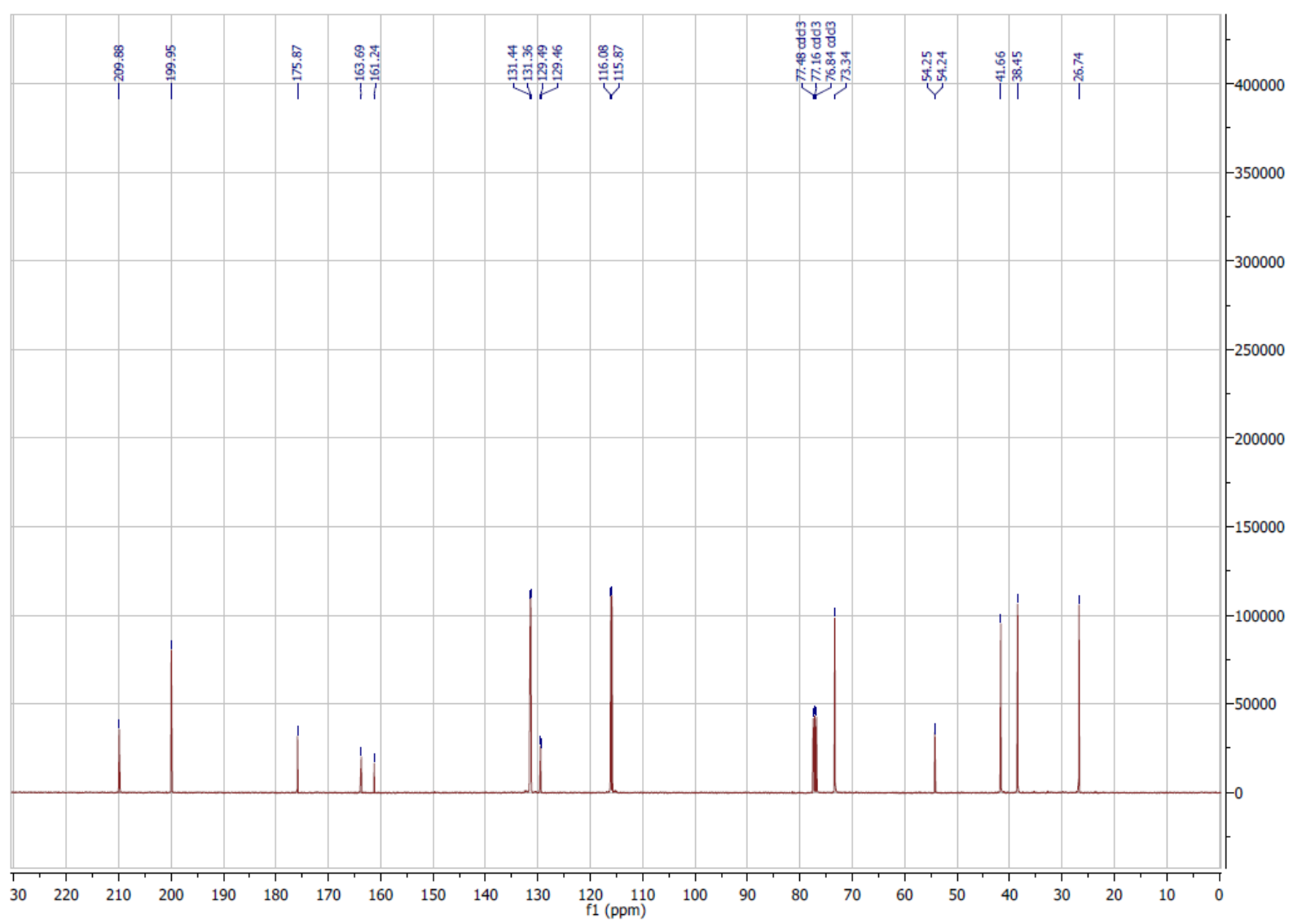


${ }^{1} \mathrm{H} \mathrm{NMR}$ of $19 \mathrm{c}$ in $\mathrm{CDCl}_{3}(400 \mathrm{MHz})$

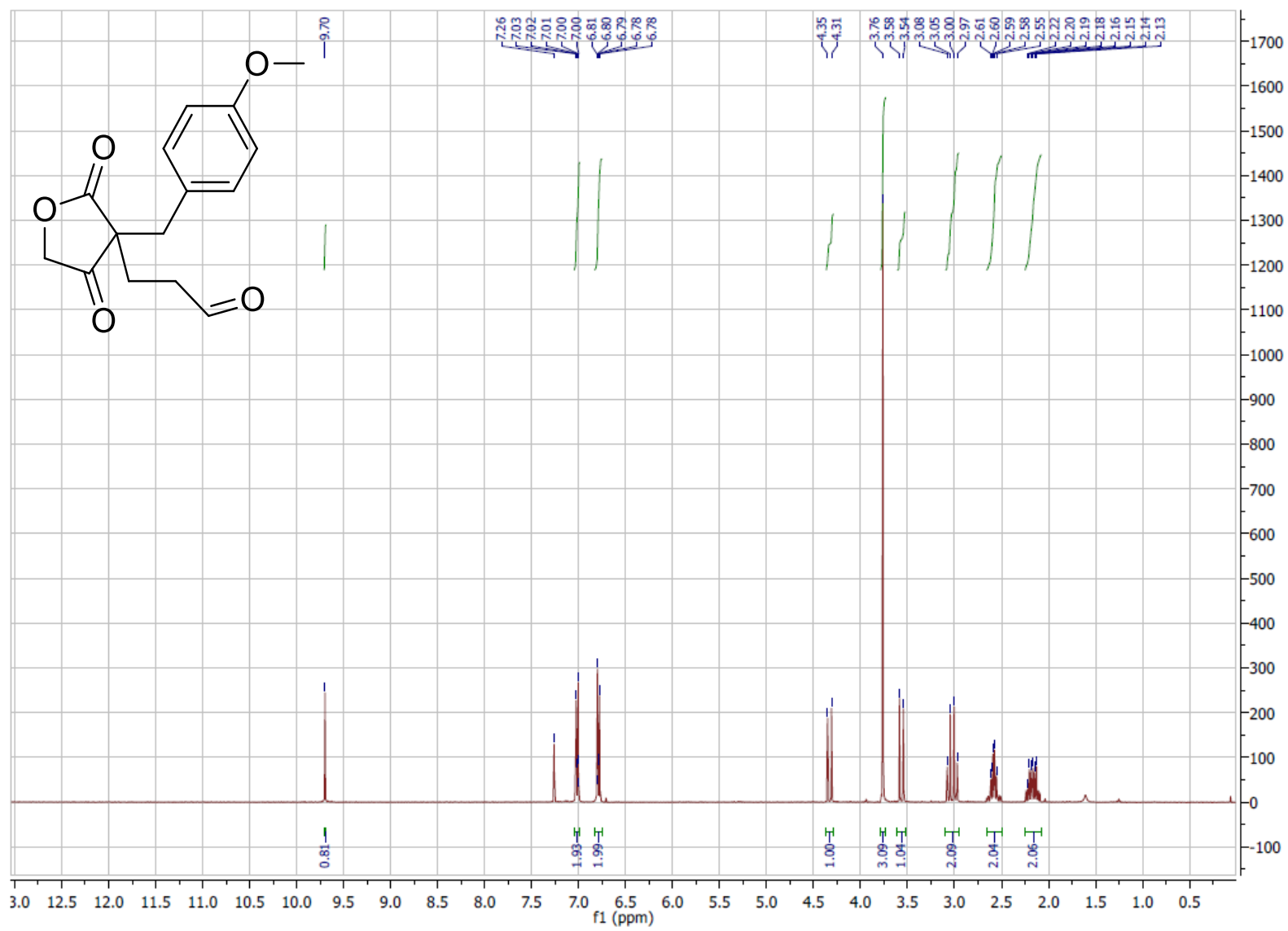

${ }^{13} \mathrm{C}$ NMR of $19 \mathrm{c}$ in $\mathrm{CDCl}_{3}(101 \mathrm{MHz})$

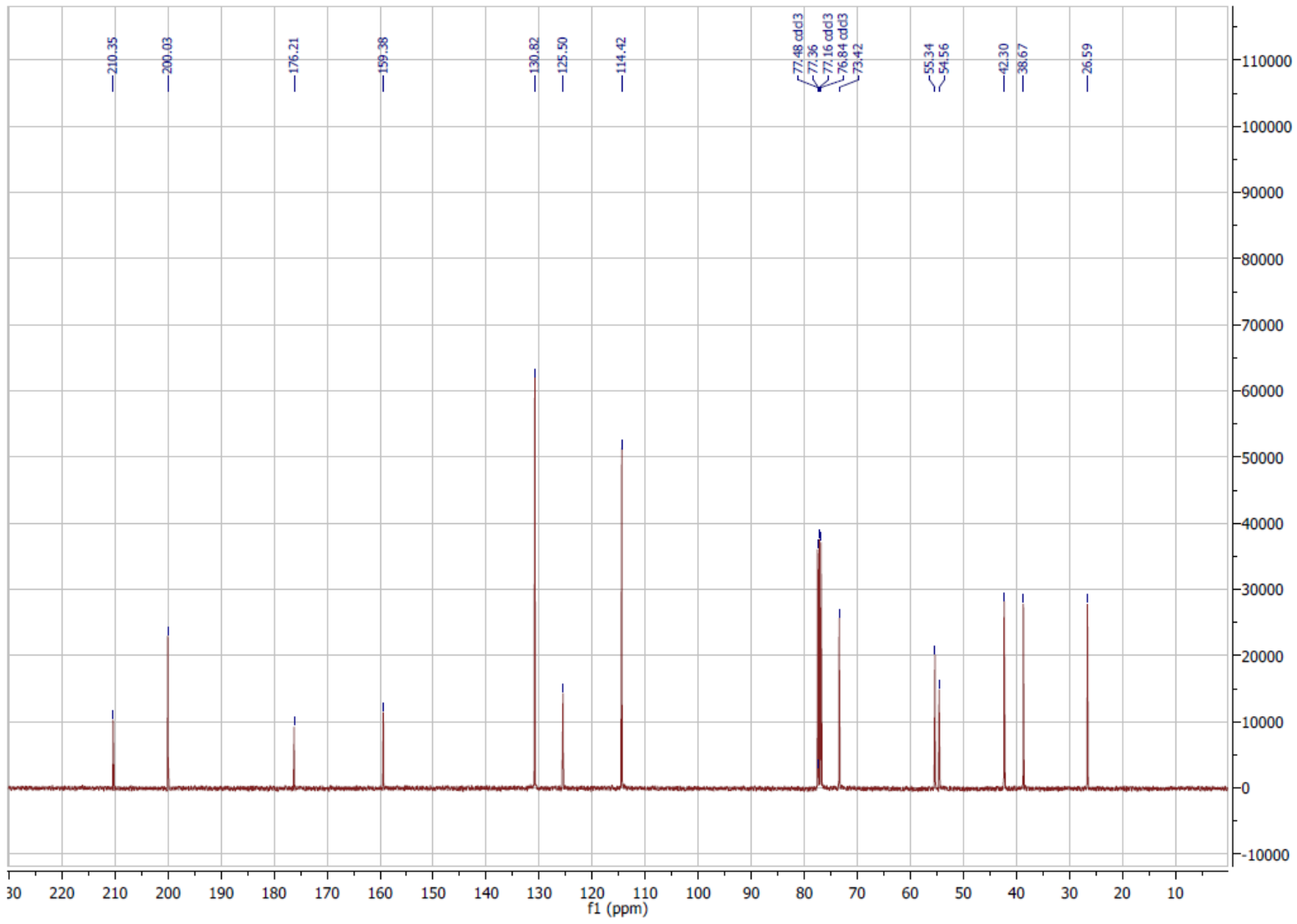


${ }^{1} \mathrm{H} \mathrm{NMR}$ of 7a in $\mathrm{CDCl}_{3}(500 \mathrm{MHz})$

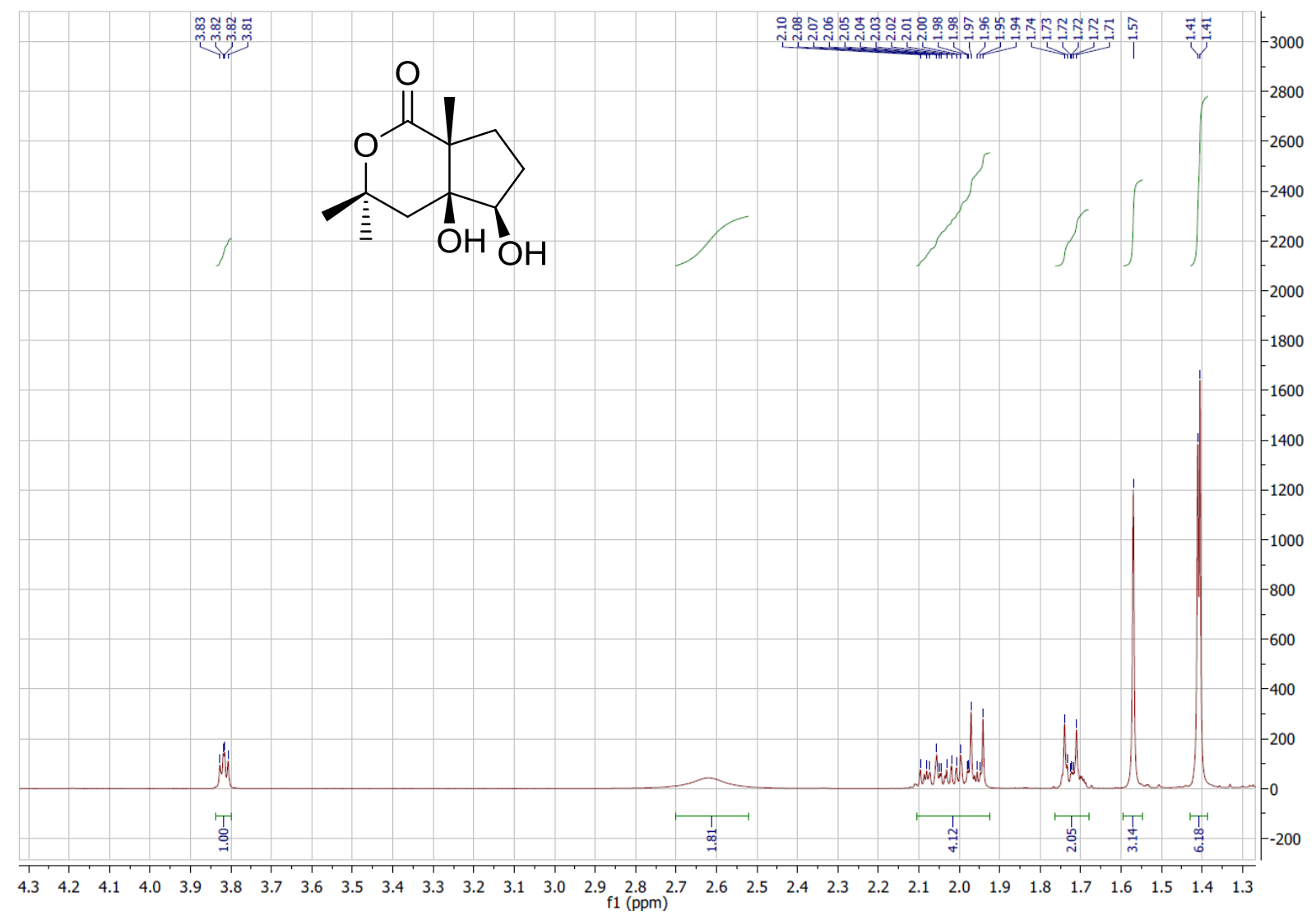

${ }^{13} \mathrm{C}$ NMR of $7 \mathbf{a}$ in $\mathrm{CDCl}_{3}(126 \mathrm{MHz})$

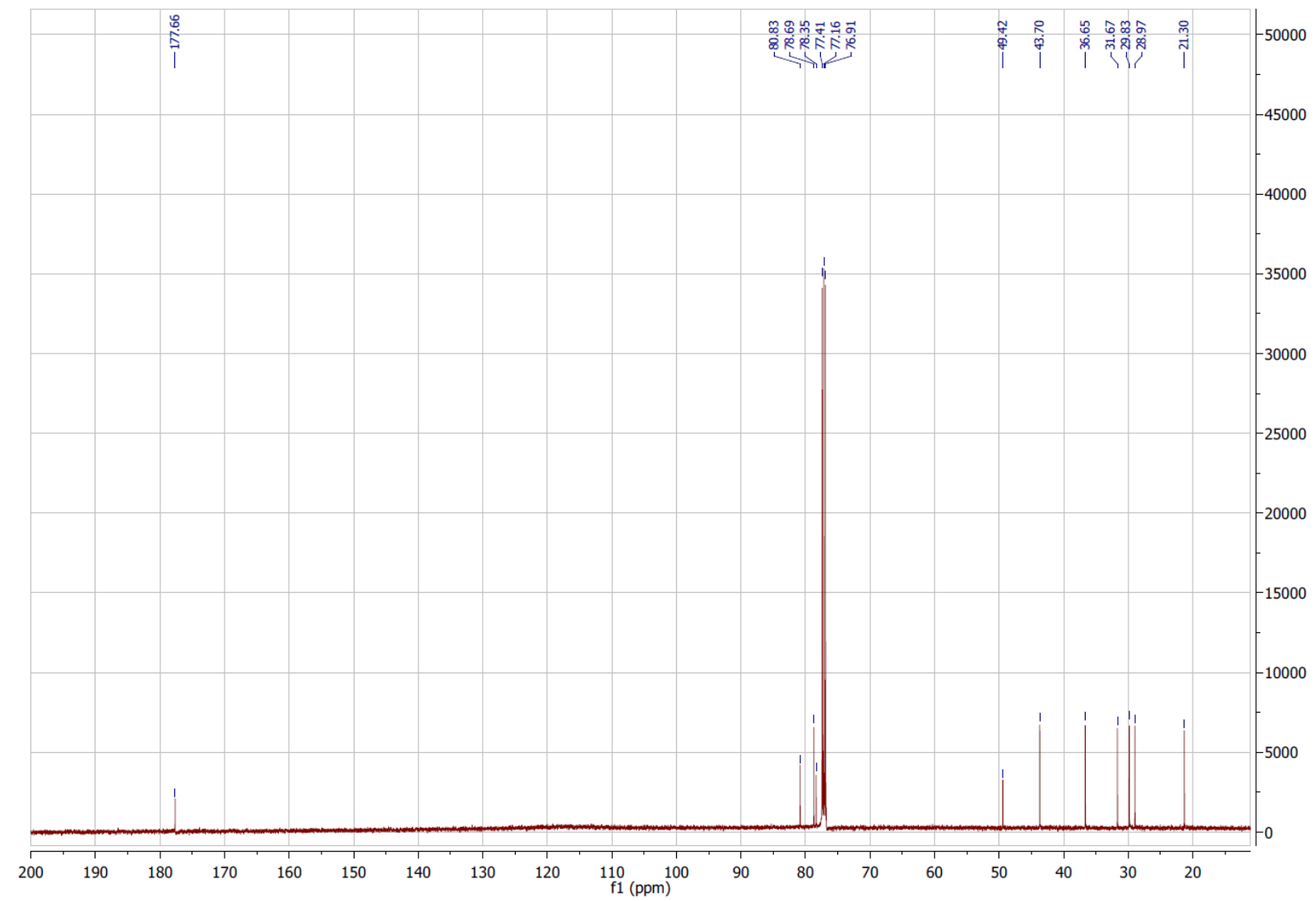


${ }^{1} \mathrm{H} \mathrm{NMR}$ of $\mathbf{7 b}$ in $\mathrm{CDCl}_{3}(400 \mathrm{MHz})$

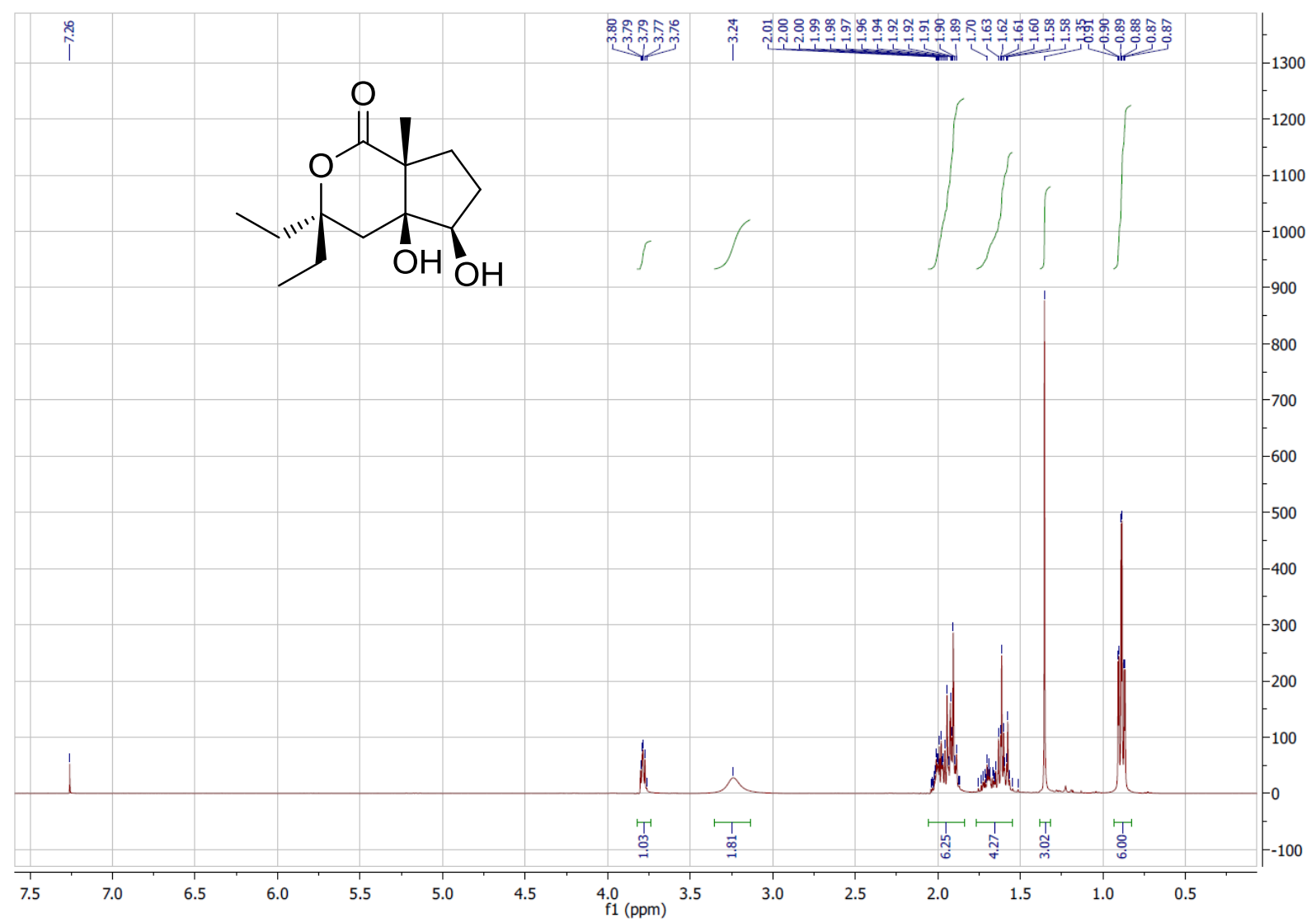

${ }^{13} \mathrm{C}$ NMR of $7 \mathbf{b}$ in $\mathrm{CDCl}_{3}(101 \mathrm{MHz})$

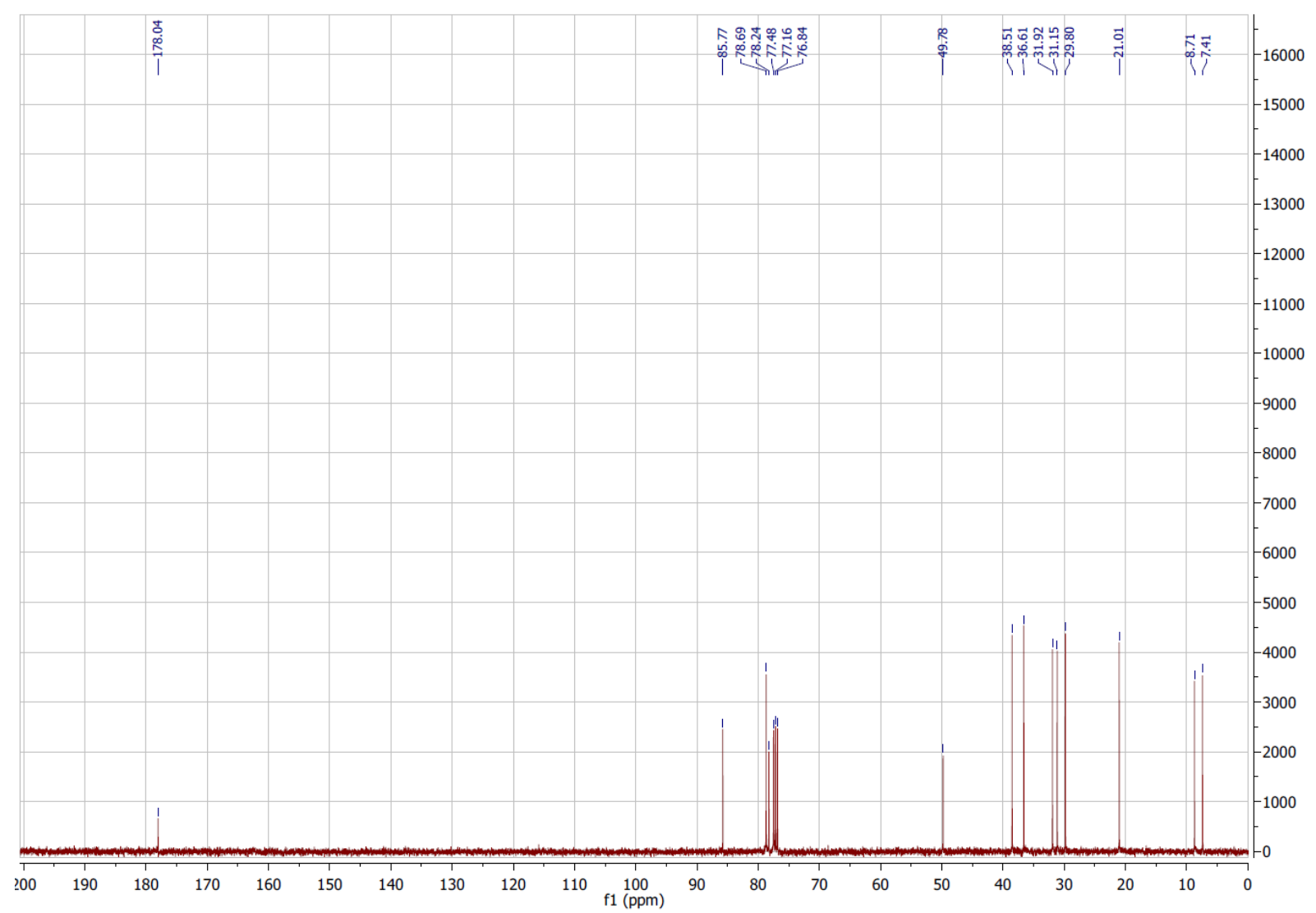


${ }^{1} \mathrm{H}$ NMR of $7 \mathbf{c}$ in $\mathrm{CDCl}_{3}(600 \mathrm{MHz})$

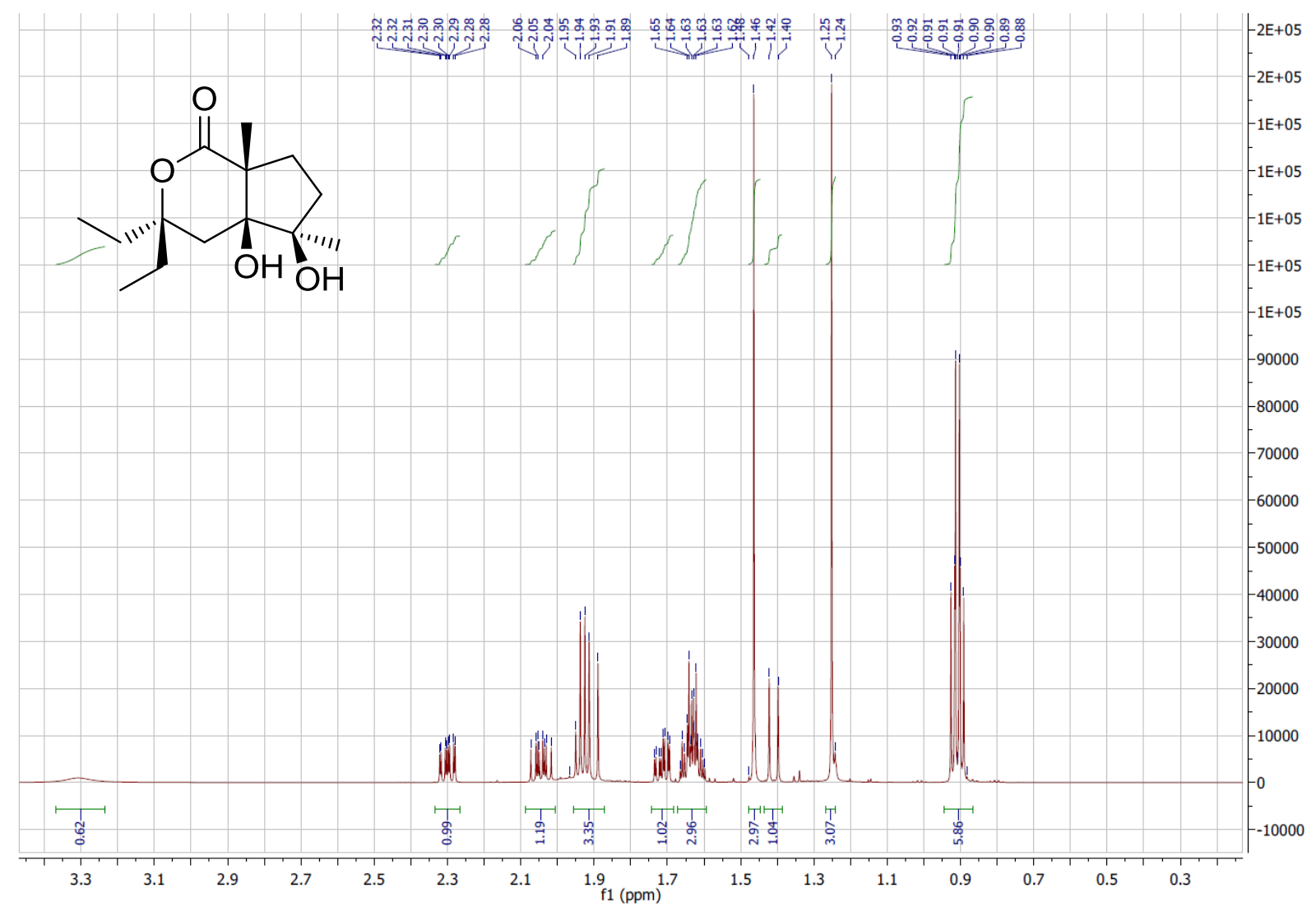

${ }^{13} \mathrm{C}$ NMR of $7 \mathbf{c}$ in $\mathrm{CDCl}_{3}(151 \mathrm{MHz})$

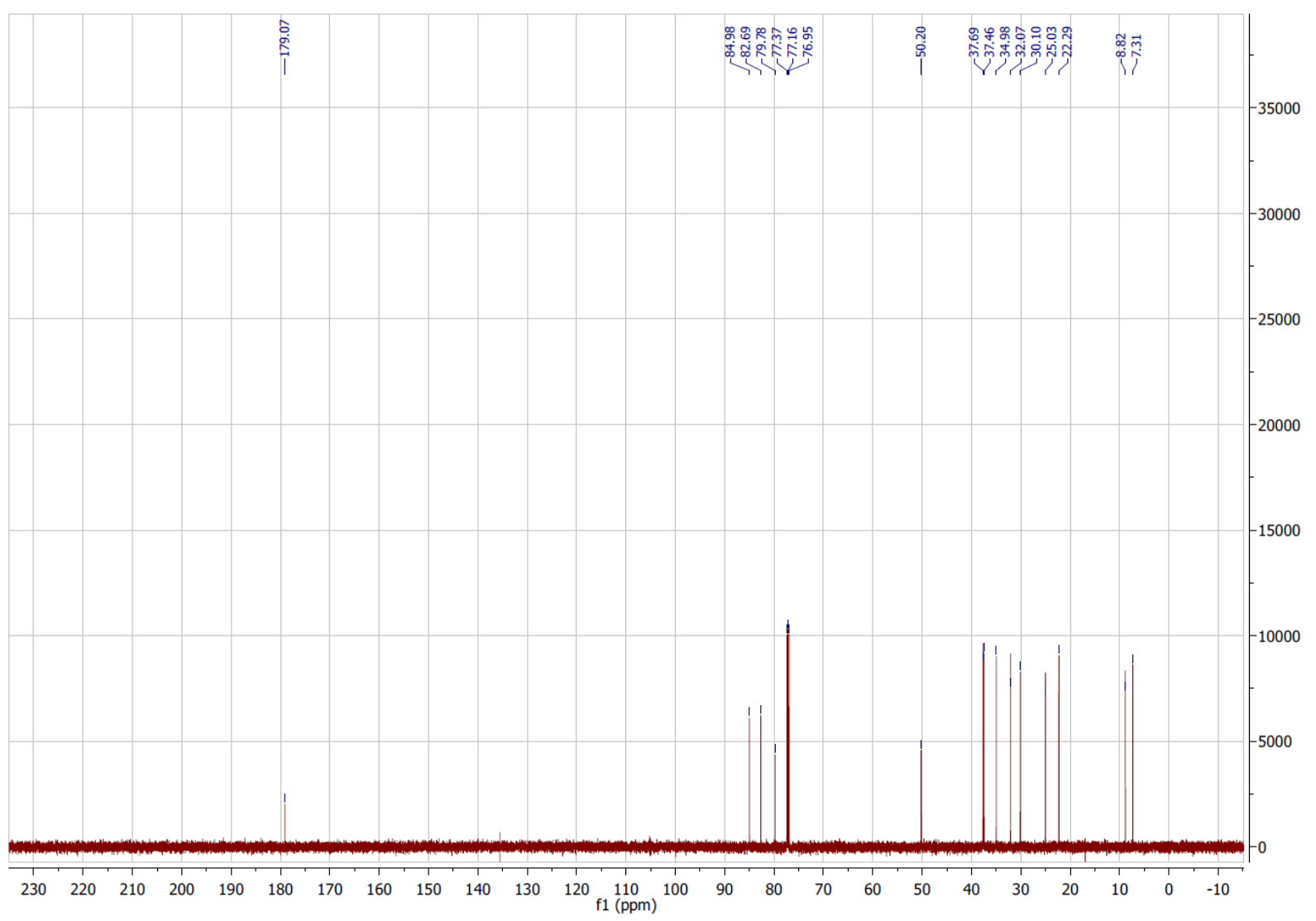


${ }^{1} \mathrm{H} \mathrm{NMR}$ of $7 \mathbf{d}$ in $\mathrm{CDCl}_{3}(400 \mathrm{MHz})$

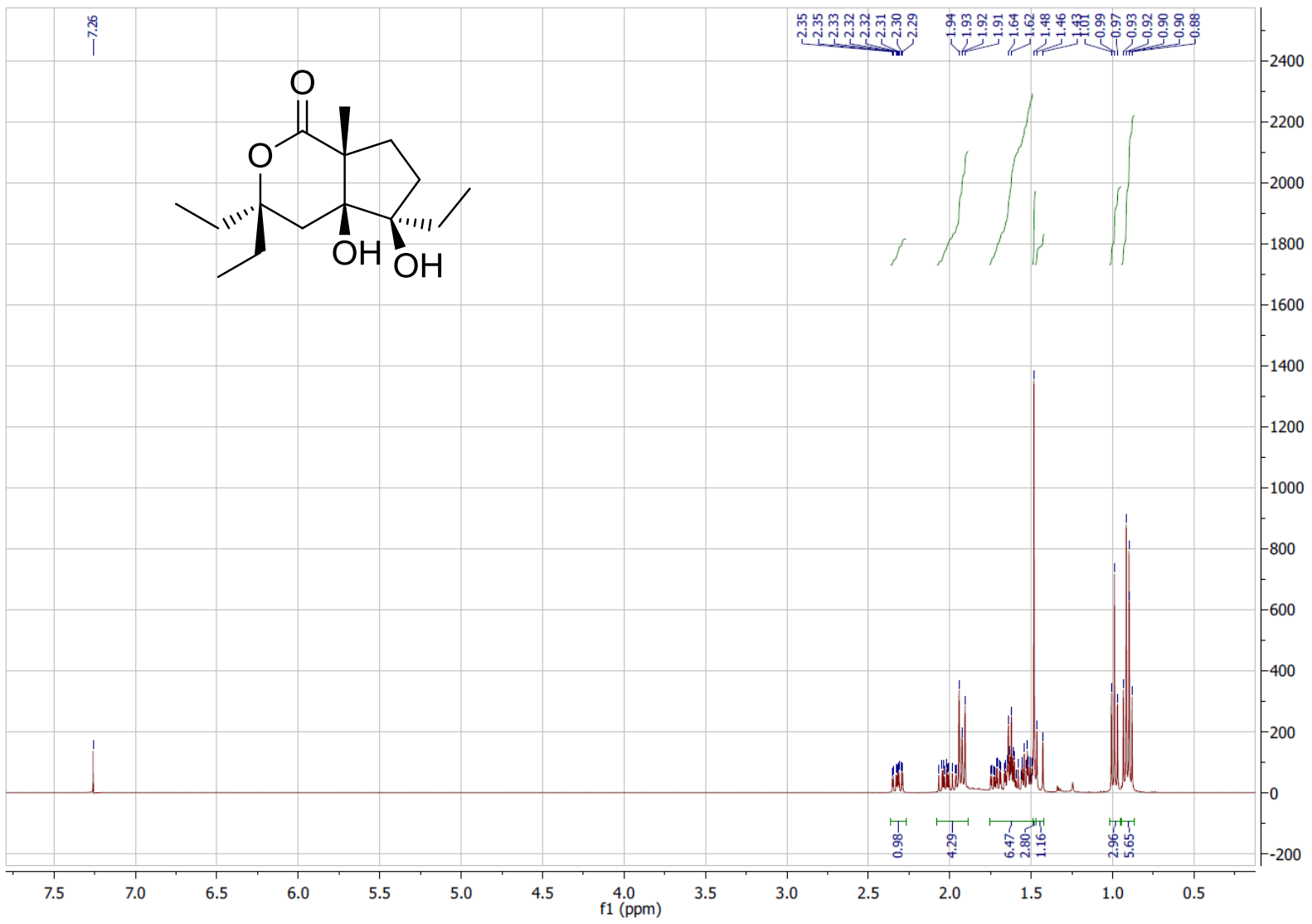

${ }^{13} \mathrm{C}$ NMR of $7 \mathbf{d}$ in $\mathrm{CDCl}_{3}(101 \mathrm{MHz})$

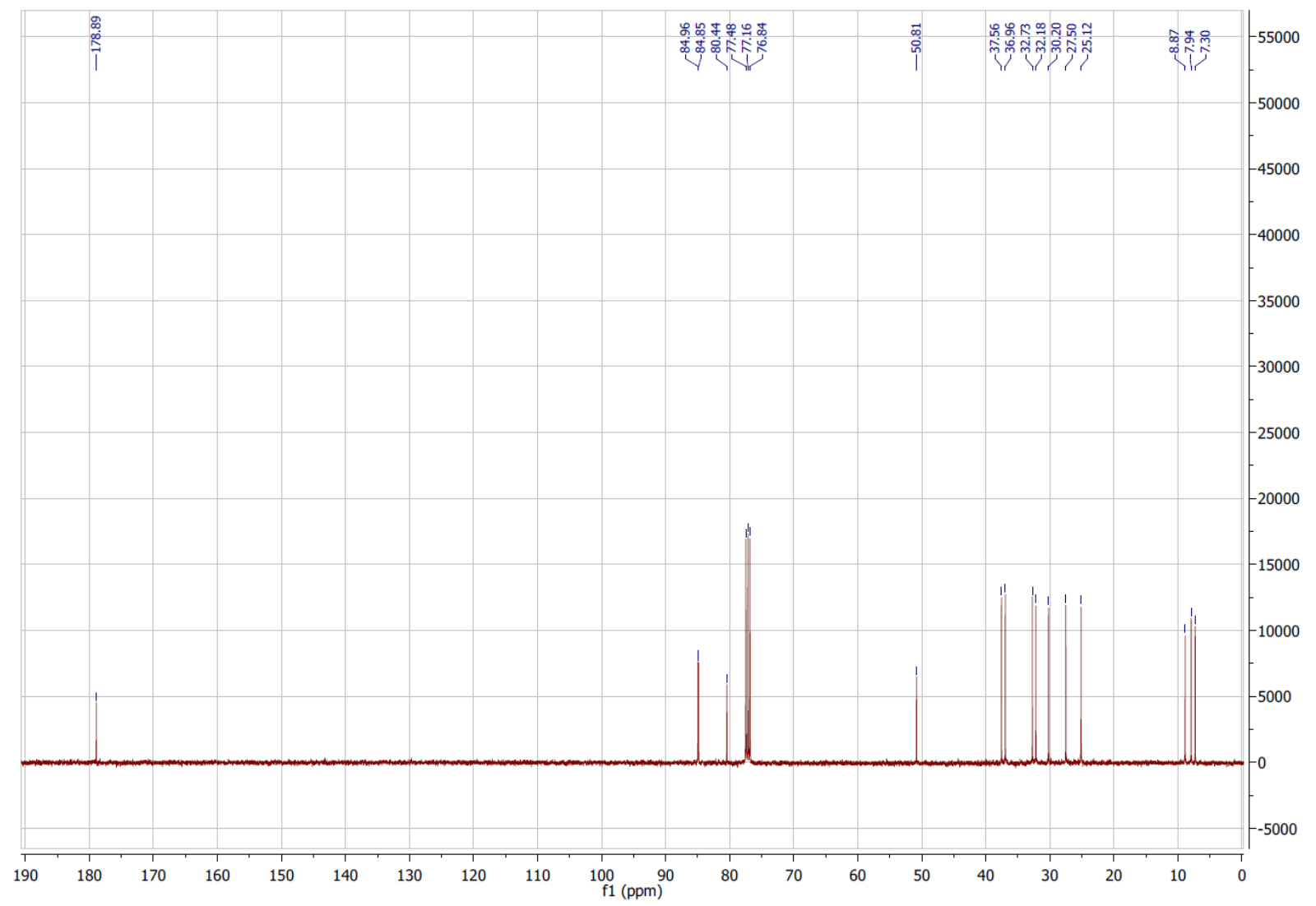


${ }^{1} \mathrm{H}$ NMR of $\mathbf{8 a}$ in $\mathrm{CDCl}_{3}(500 \mathrm{MHz})$

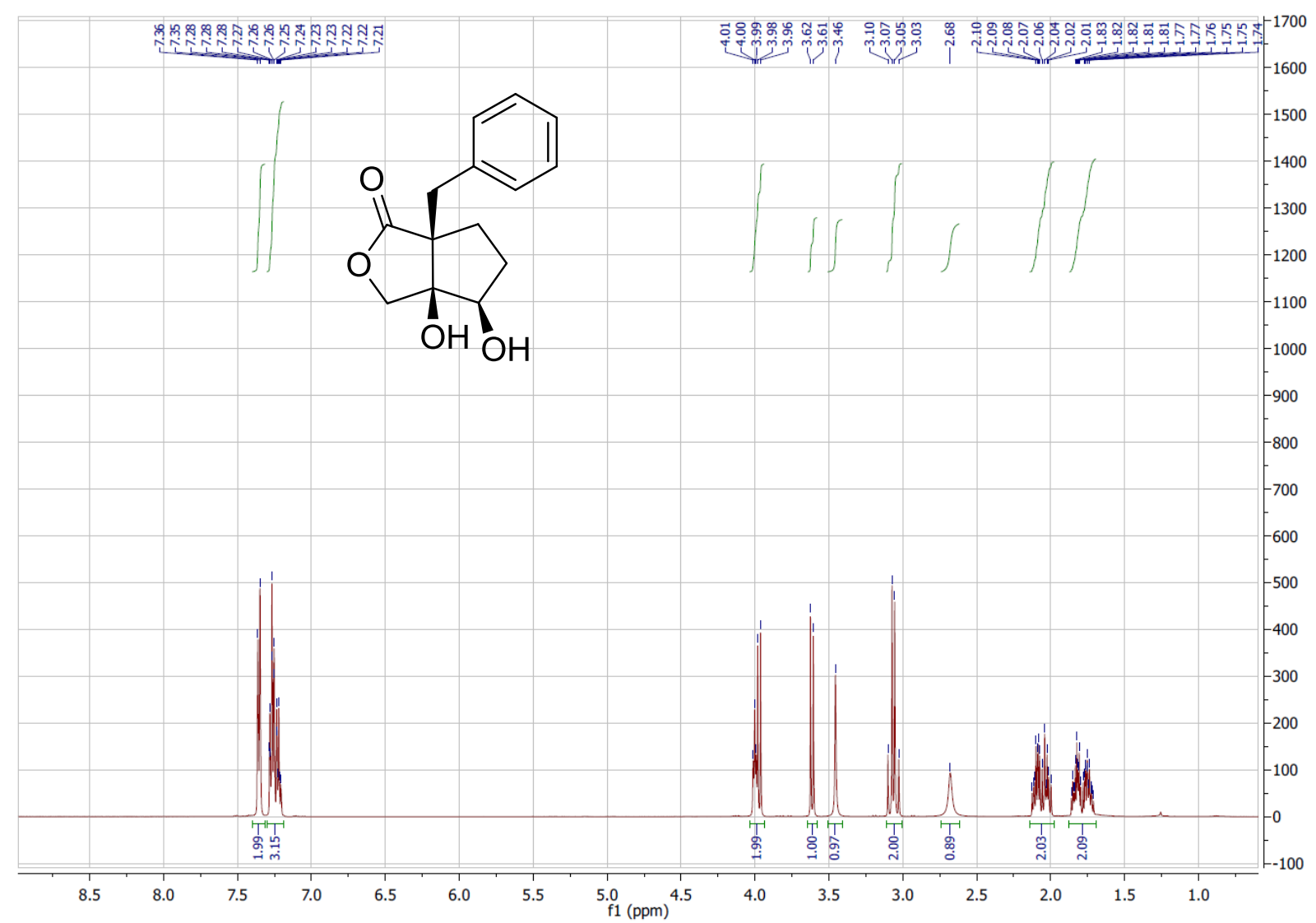

${ }^{13} \mathrm{C}$ NMR of $\mathbf{8 a}$ in $\mathrm{CDCl}_{3}(126 \mathrm{MHz})$

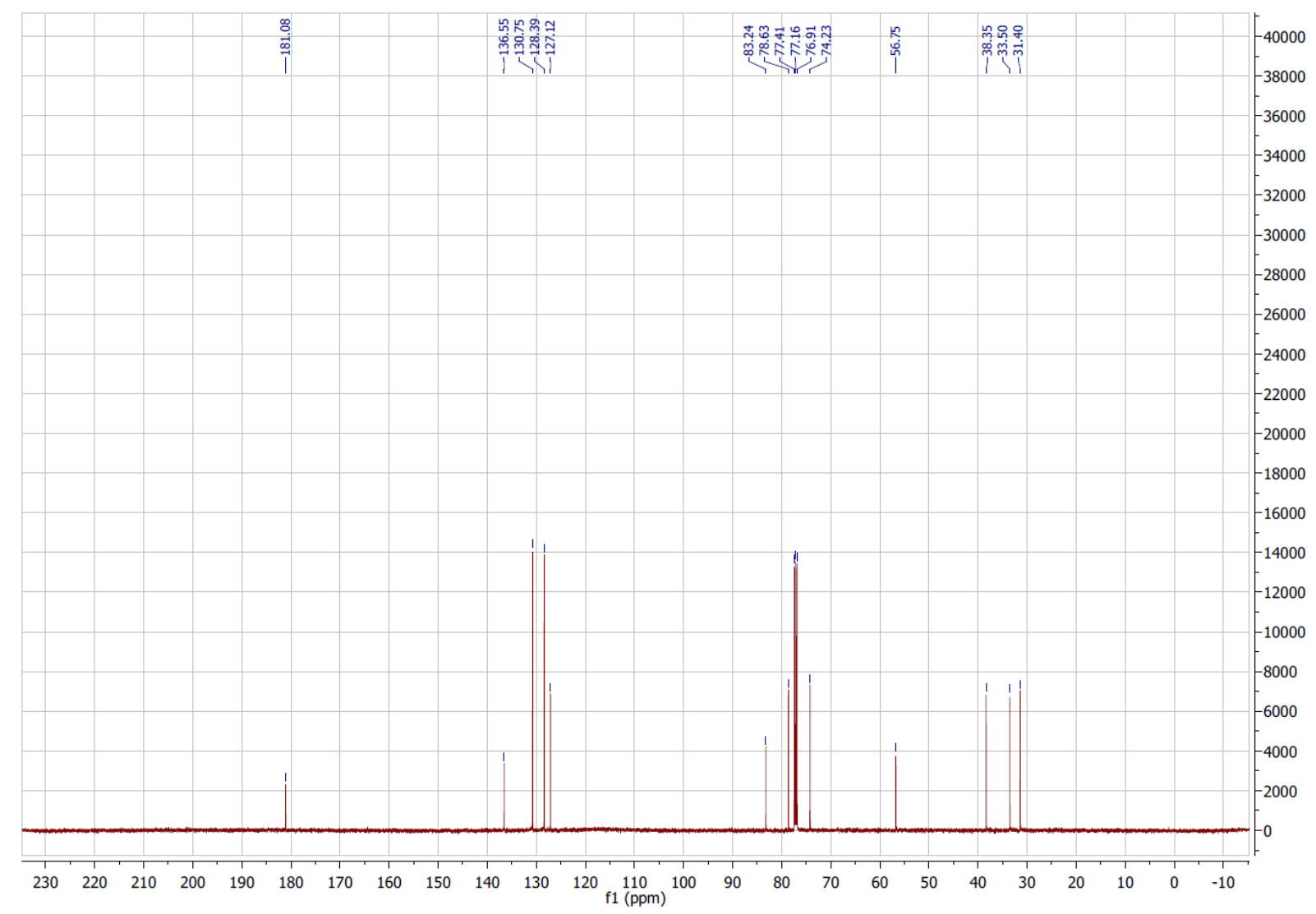


${ }^{1} \mathrm{H}$ NMR of $\mathbf{8 b}$ in $\mathrm{CDCl}_{3}(400 \mathrm{MHz})$

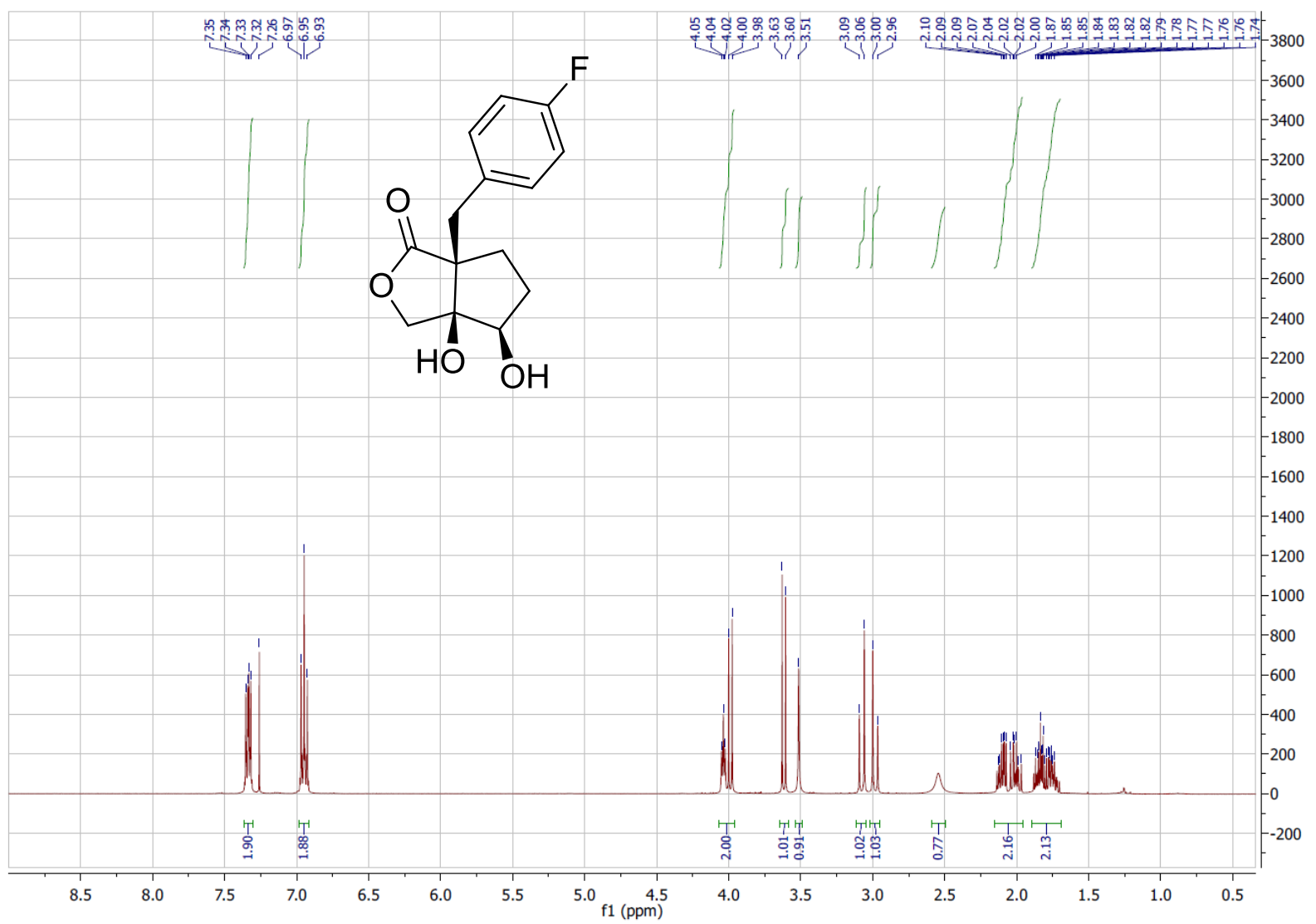

${ }^{13} \mathrm{C}$ NMR of $\mathbf{8 b}$ in $\mathrm{CDCl}_{3}(101 \mathrm{MHz})$

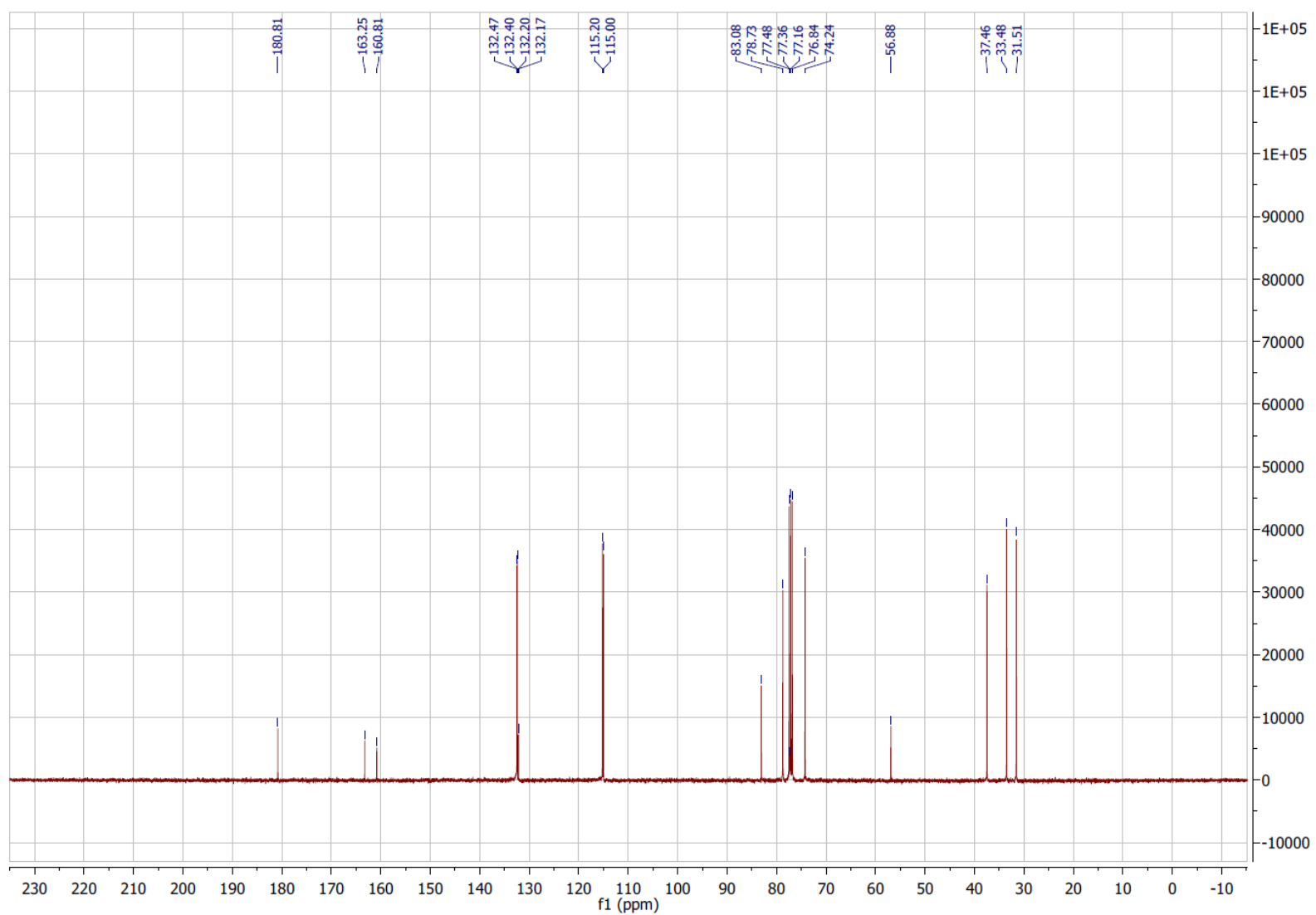


${ }^{1} \mathrm{H}$ NMR of $8 \mathbf{c}$ in $\mathrm{CDCl}_{3}(400 \mathrm{MHz})$

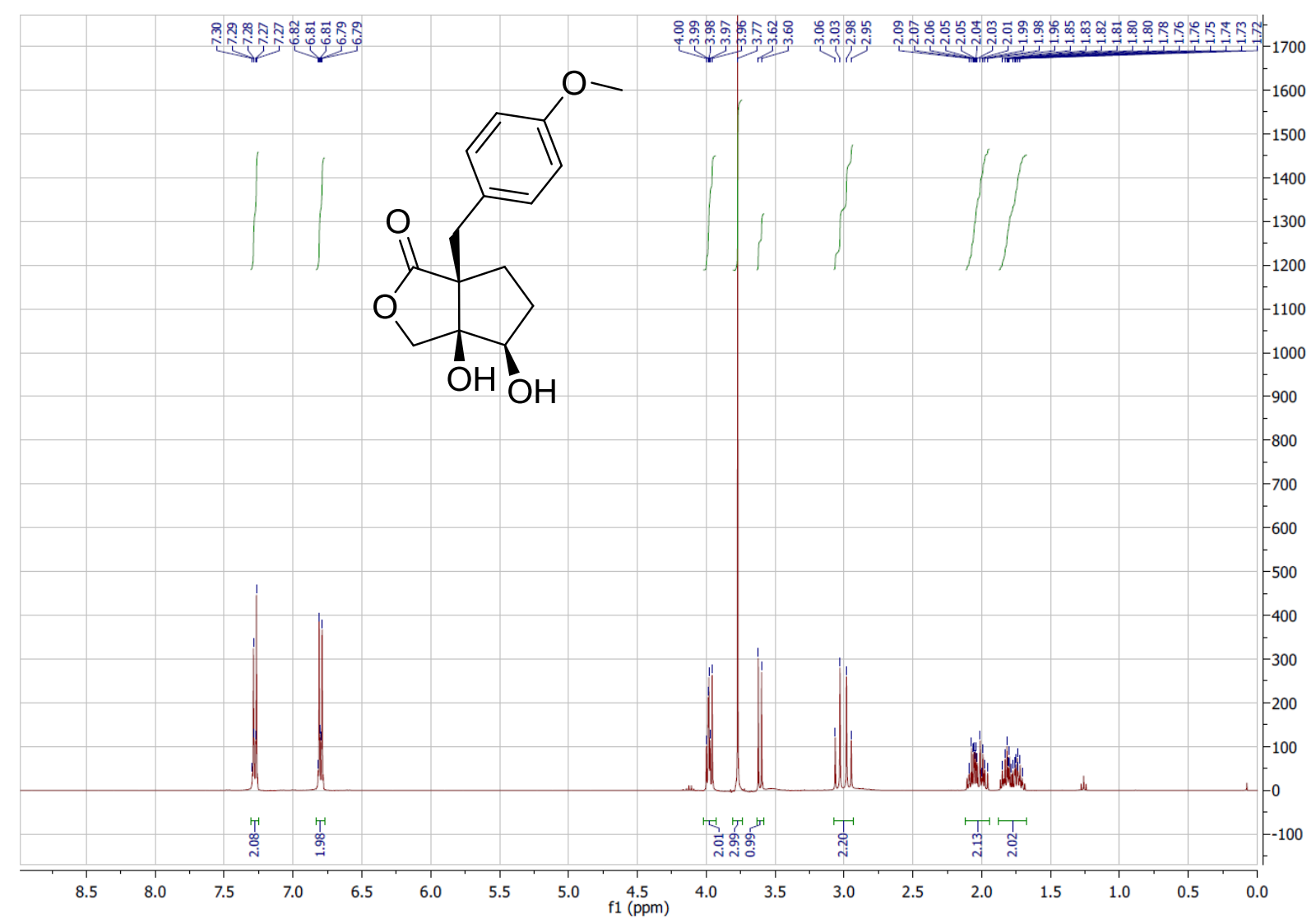

${ }^{13} \mathrm{C}$ NMR of $8 \mathbf{c}$ in $\mathrm{CDCl}_{3}(101 \mathrm{MHz})$

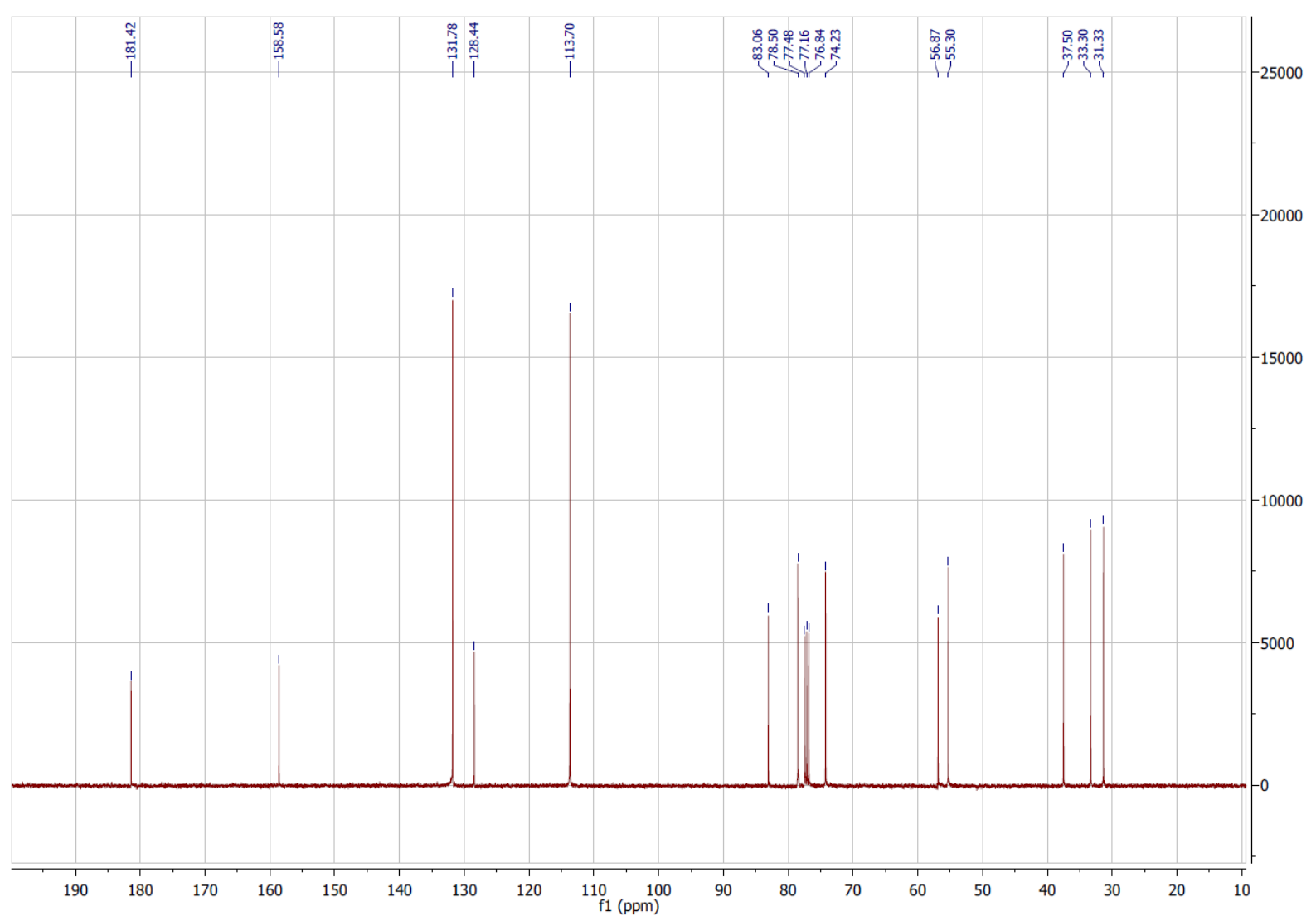


${ }^{1} \mathrm{H}$ NMR of 20a in $\mathrm{CDCl}_{3}(400 \mathrm{MHz})$

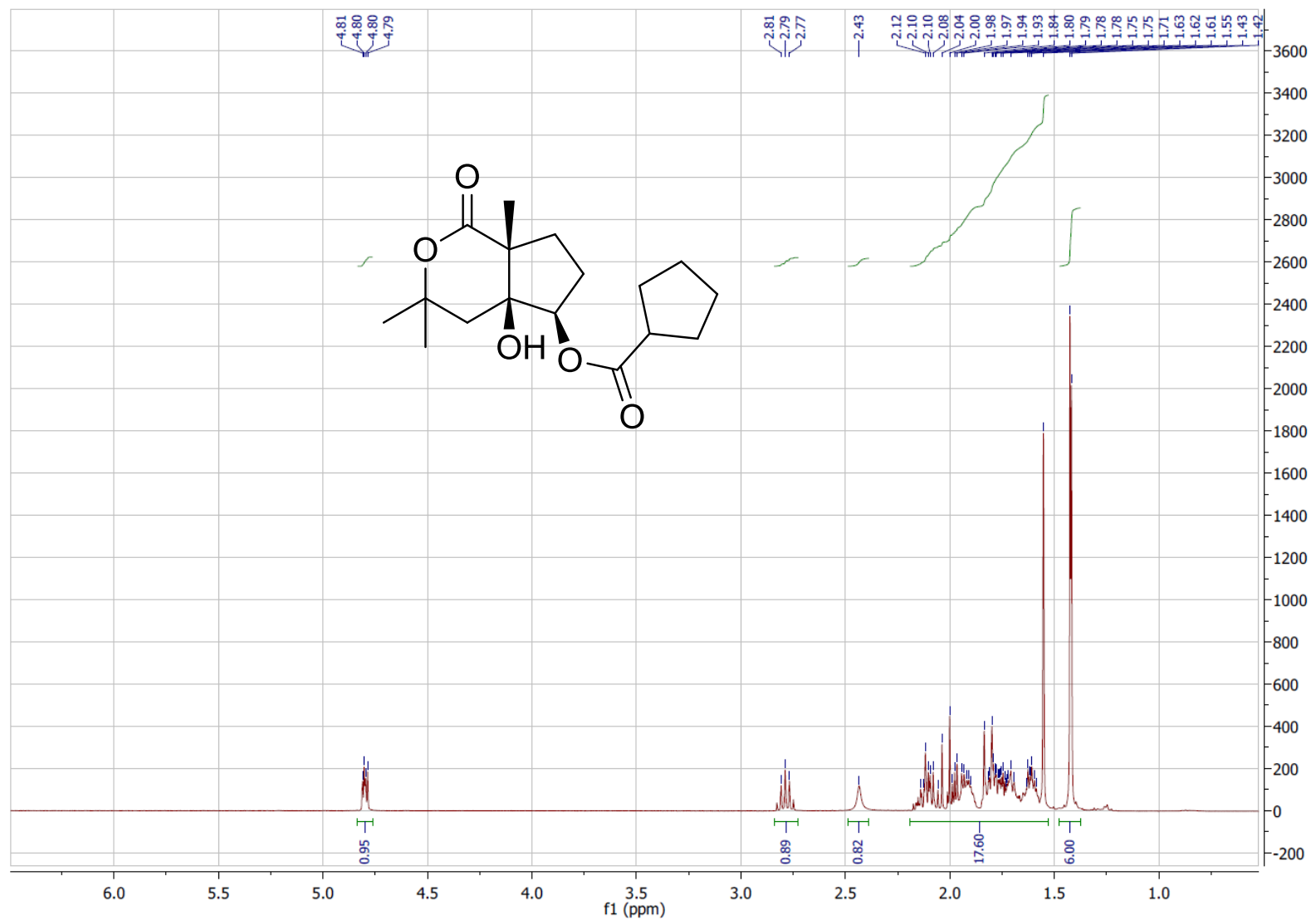

${ }^{13} \mathrm{C}$ NMR of 20a in $\mathrm{CDCl}_{3}(101 \mathrm{MHz})$

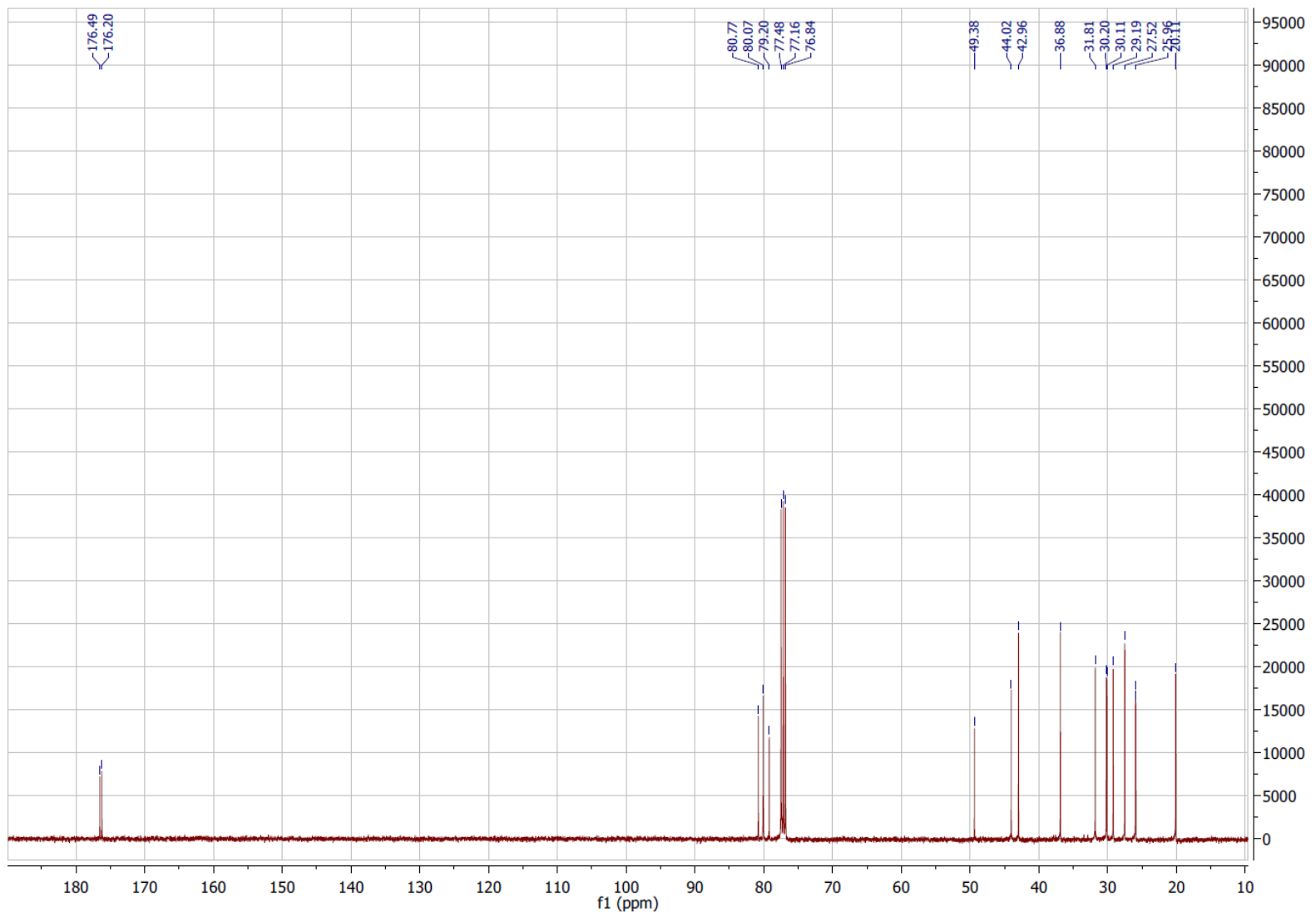


${ }^{1} \mathrm{H} \mathrm{NMR}$ of 20b in $\mathrm{CDCl}_{3}(500 \mathrm{MHz})$

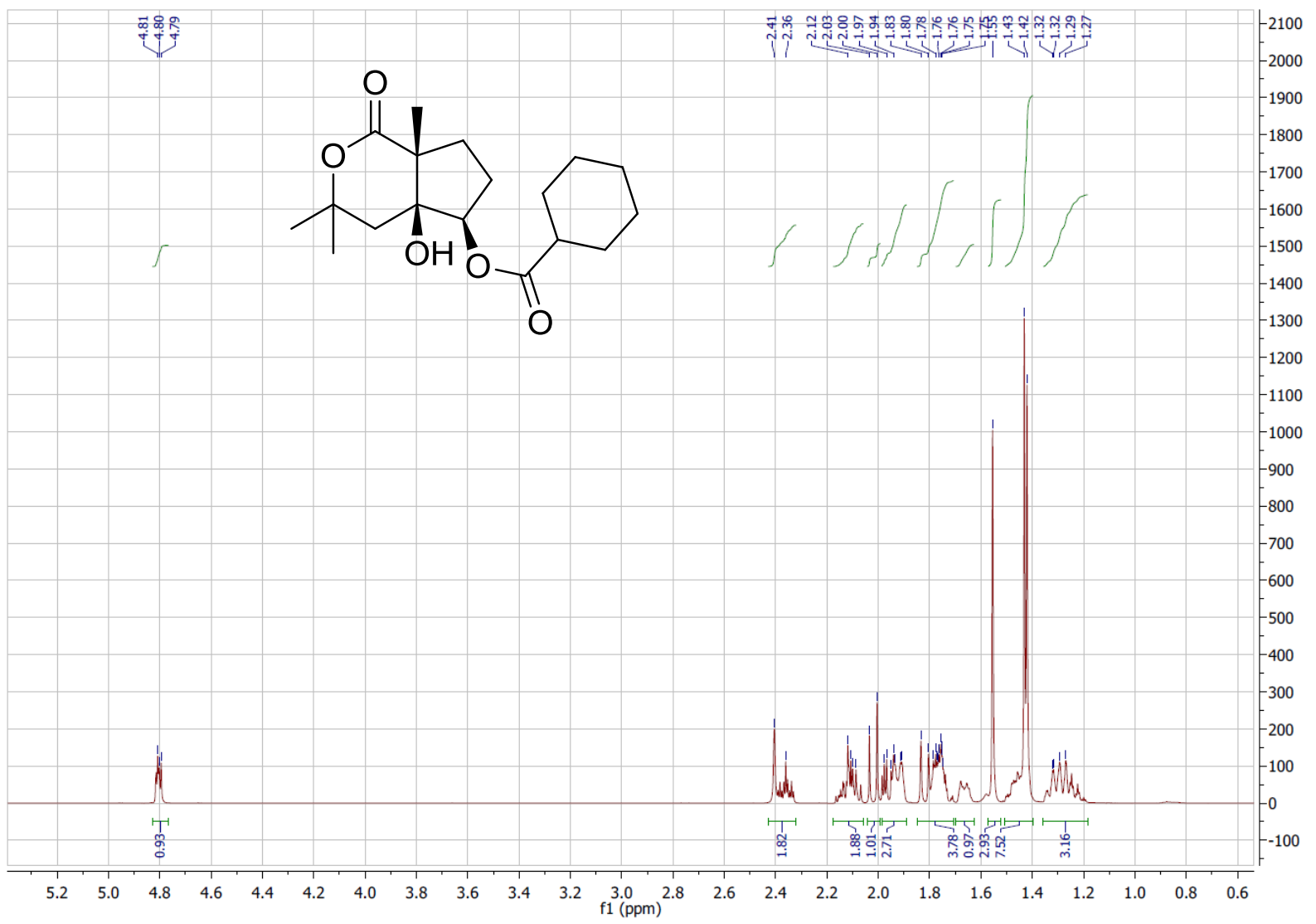

${ }^{13} \mathrm{C}$ NMR of $20 \mathrm{~b}$ in $\mathrm{CDCl}_{3}(126 \mathrm{MHz})$

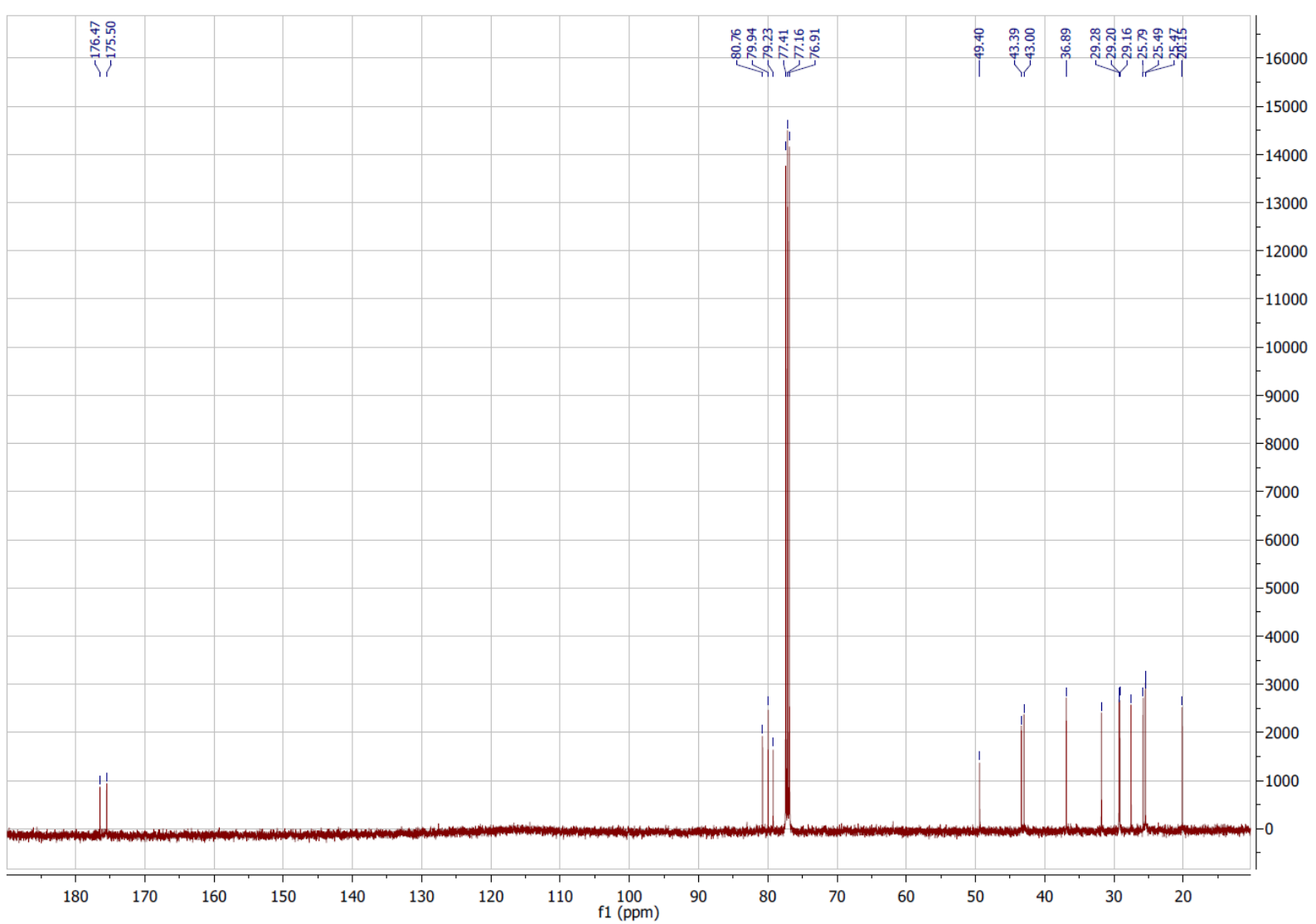


${ }^{1} \mathrm{H} \mathrm{NMR}$ of $20 \mathrm{c}$ in $\mathrm{CDCl}_{3}(500 \mathrm{MHz})$

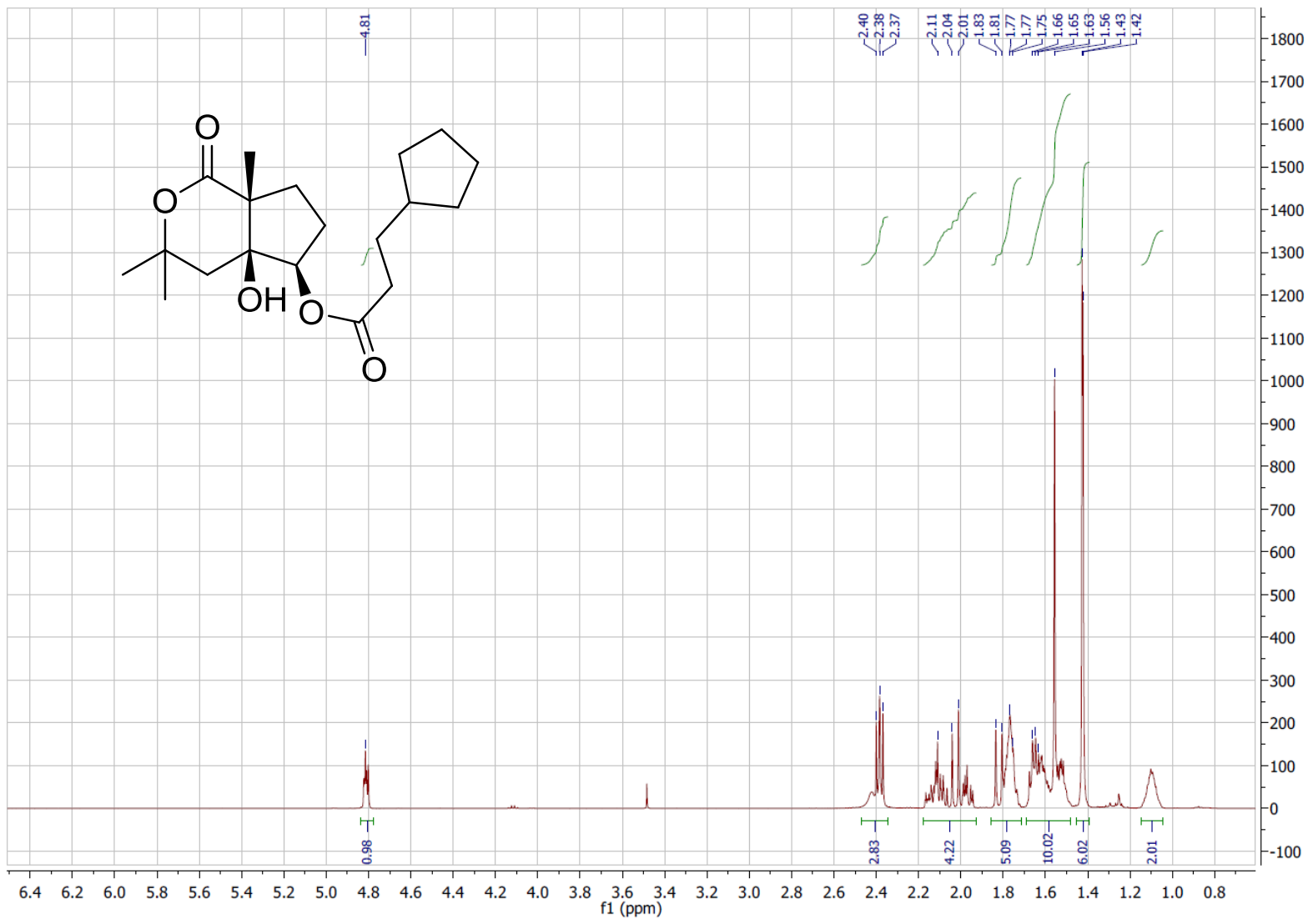

${ }^{13} \mathrm{C}$ NMR of 20c in $\mathrm{CDCl}_{3}(126 \mathrm{MHz})$

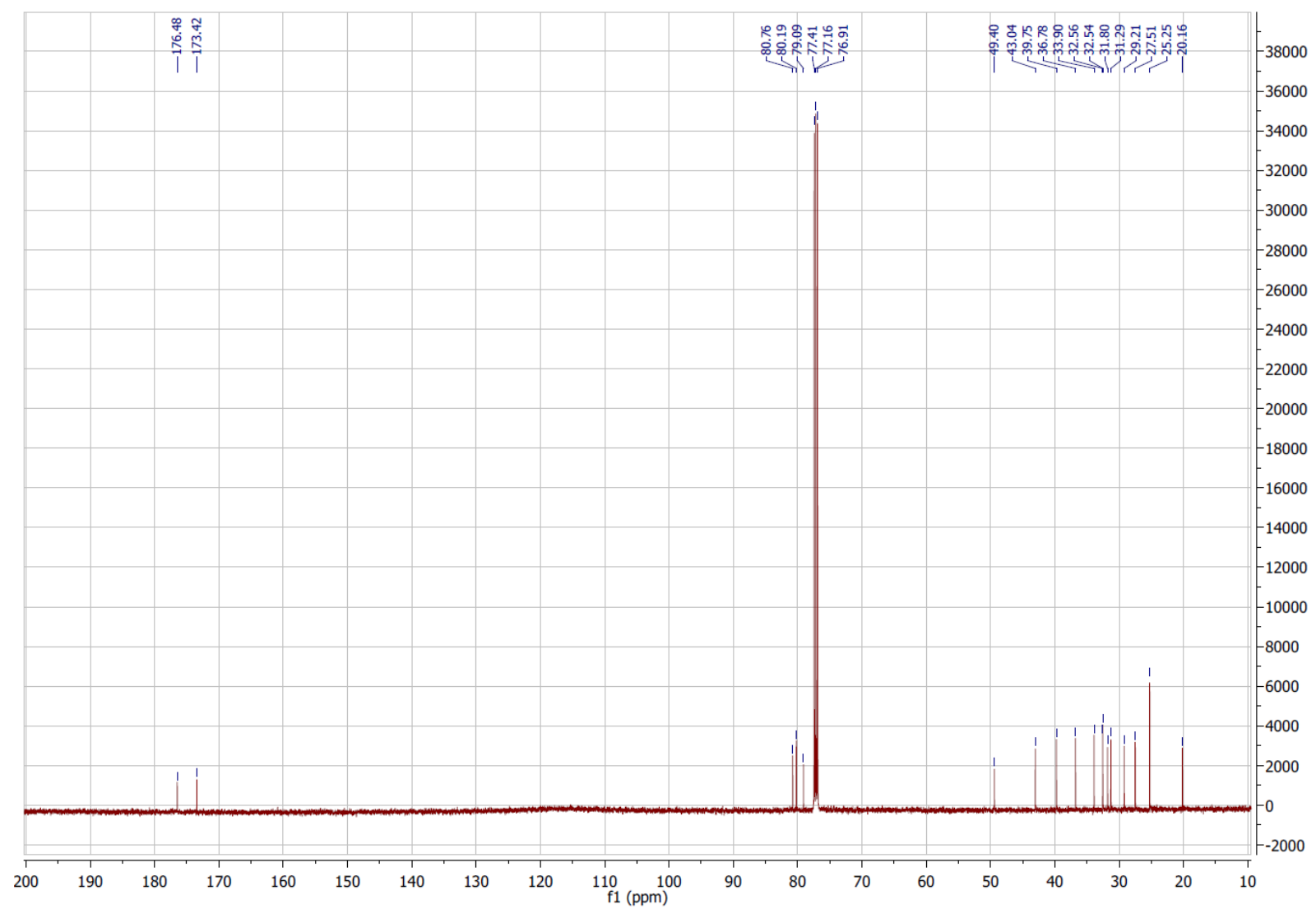


${ }^{1} \mathrm{H} \mathrm{NMR}$ of 20d in $\mathrm{CDCl}_{3}(500 \mathrm{MHz})$

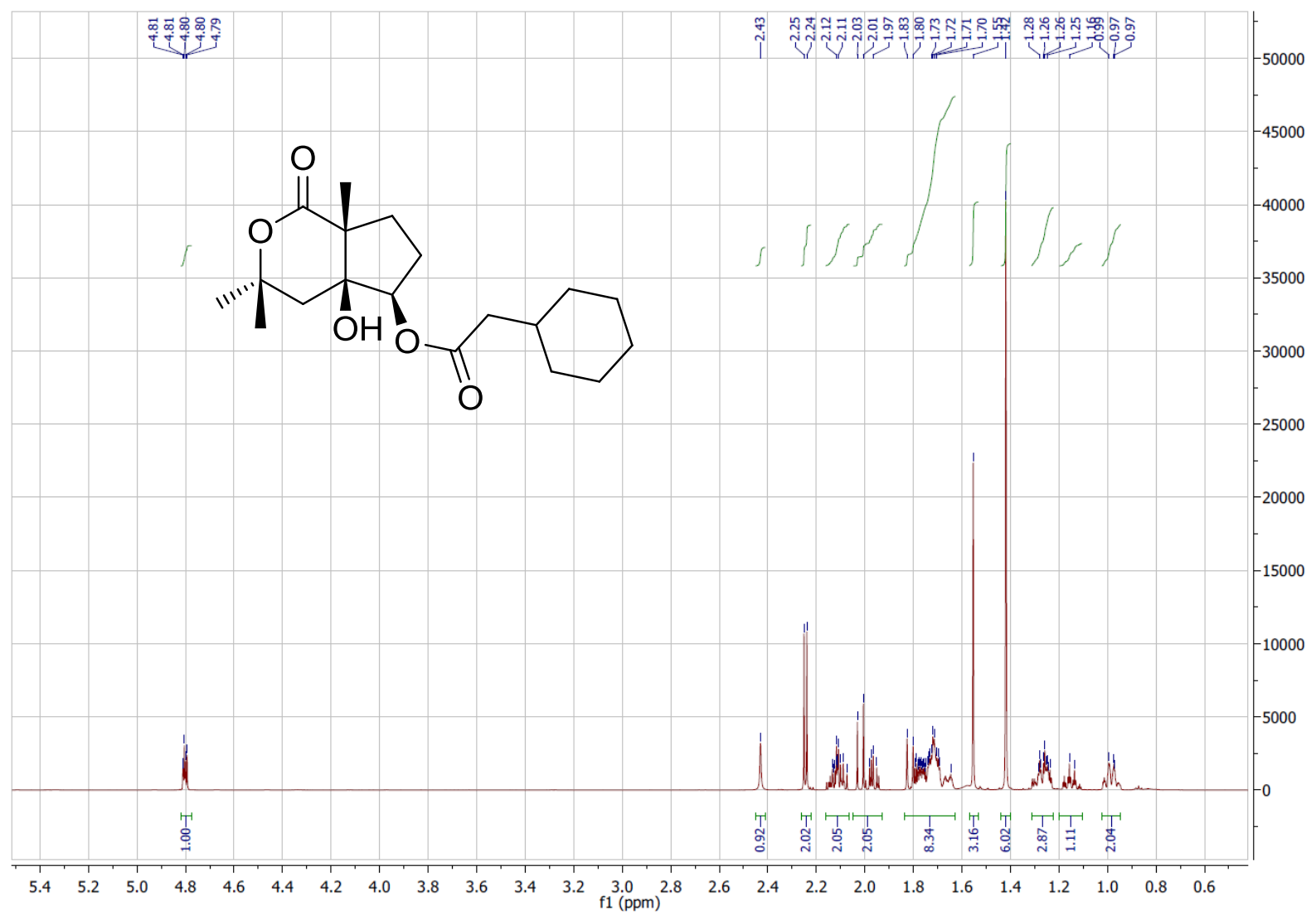

${ }^{13} \mathrm{C}$ NMR of $20 d$ in $\mathrm{CDCl}_{3}(126 \mathrm{MHz})$

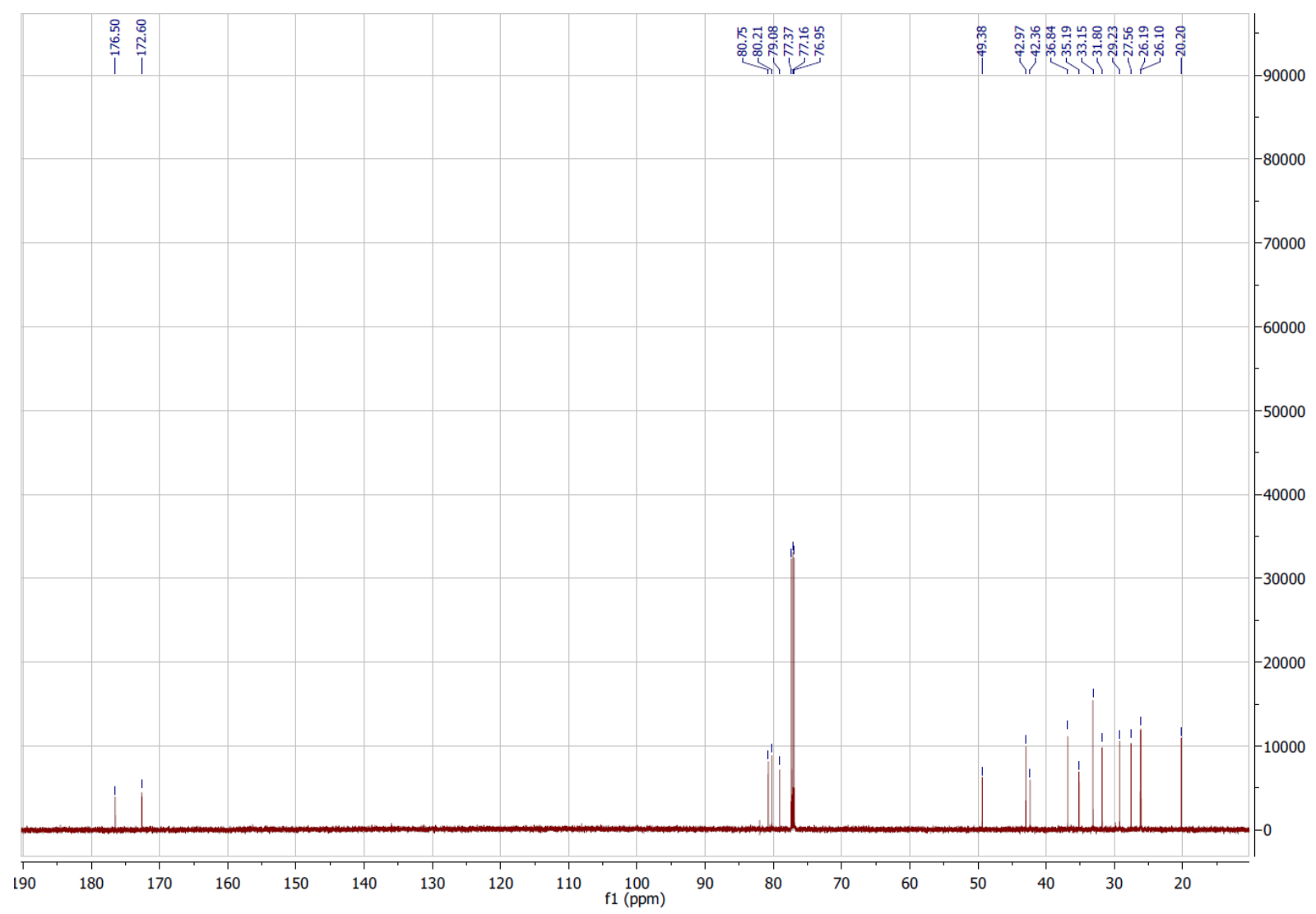


${ }^{1} \mathrm{H}$ NMR of $20 \mathrm{e}$ in $\mathrm{CDCl}_{3}(600 \mathrm{MHz})$

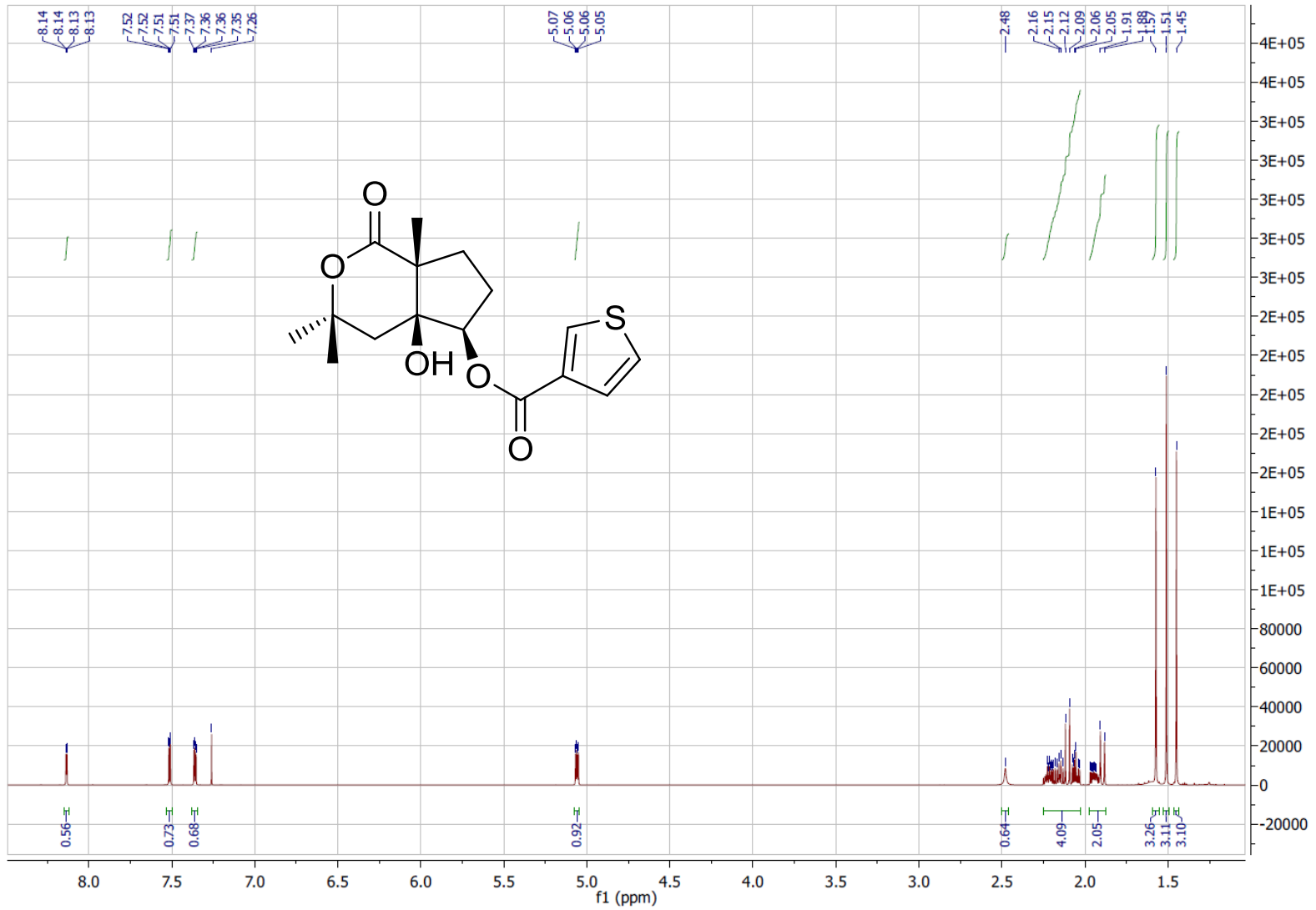

${ }^{13} \mathrm{C}$ NMR of $20 \mathrm{e}$ in $\mathrm{CDCl}_{3}(151 \mathrm{MHz})$

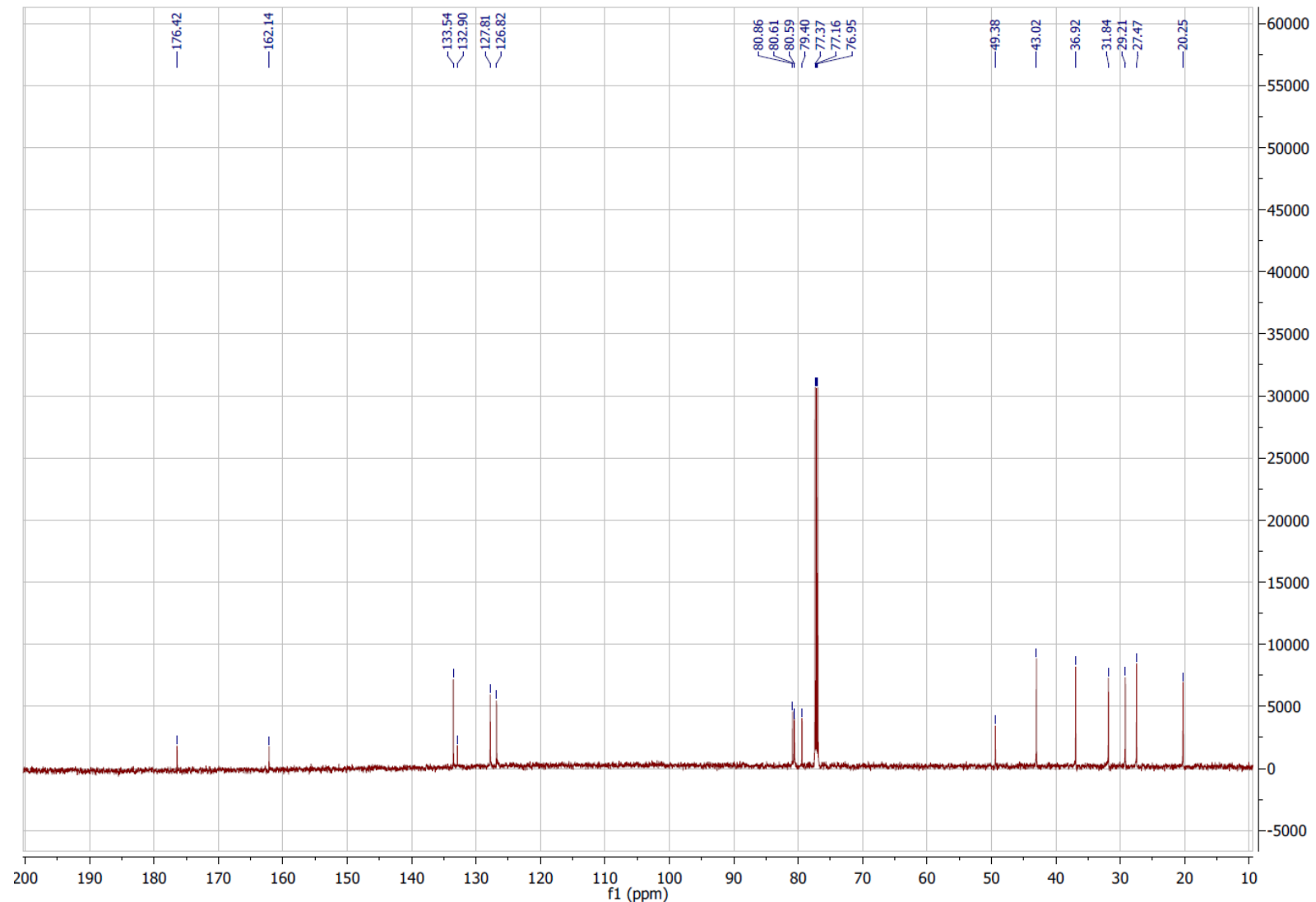


${ }^{1} \mathrm{H}$ NMR of $20 f$ in $\mathrm{CDCl}_{3}(400 \mathrm{MHz})$

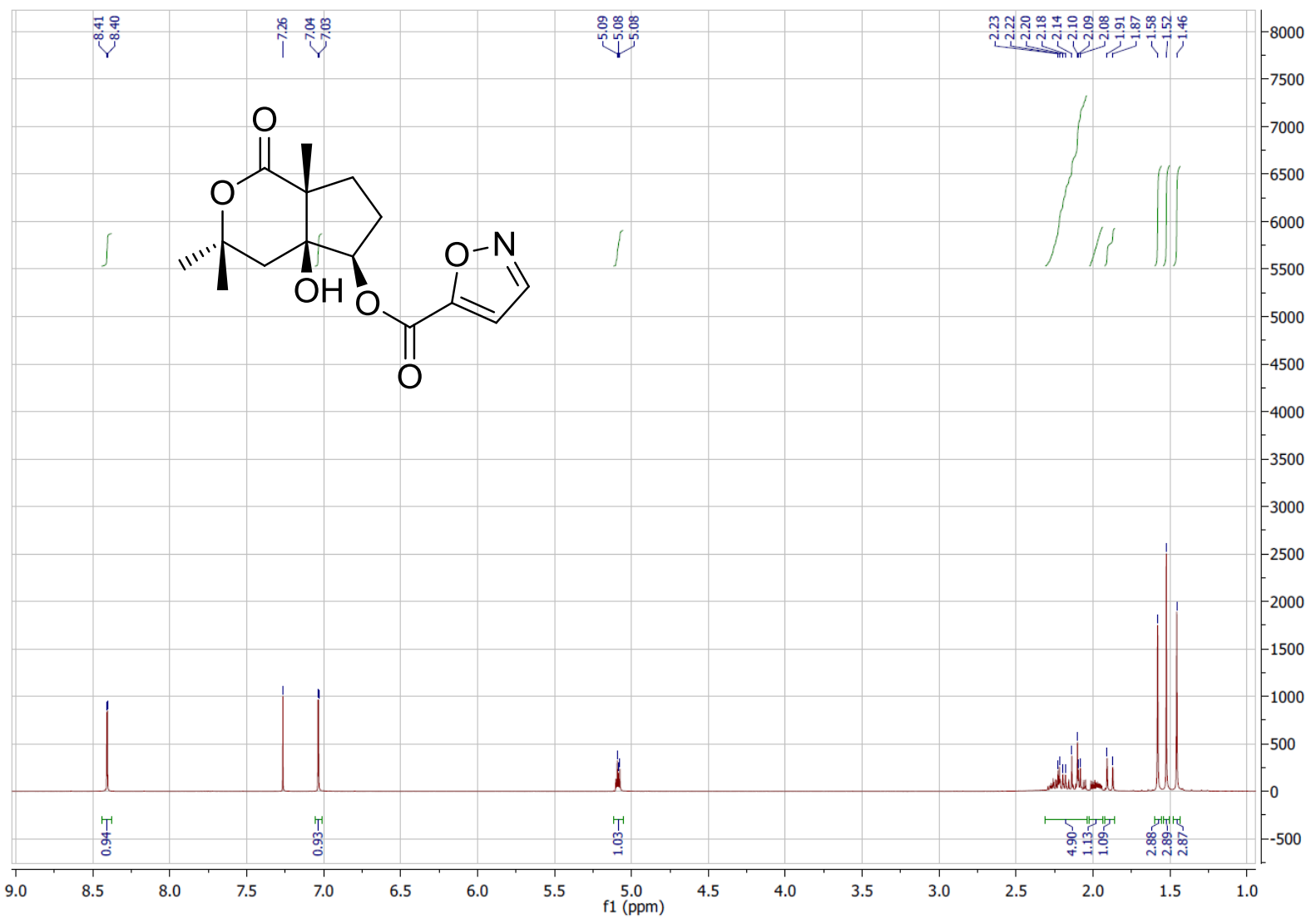

${ }^{13} \mathrm{C}$ NMR of $20 f$ in $\mathrm{CDCl}_{3}(101 \mathrm{MHz})$

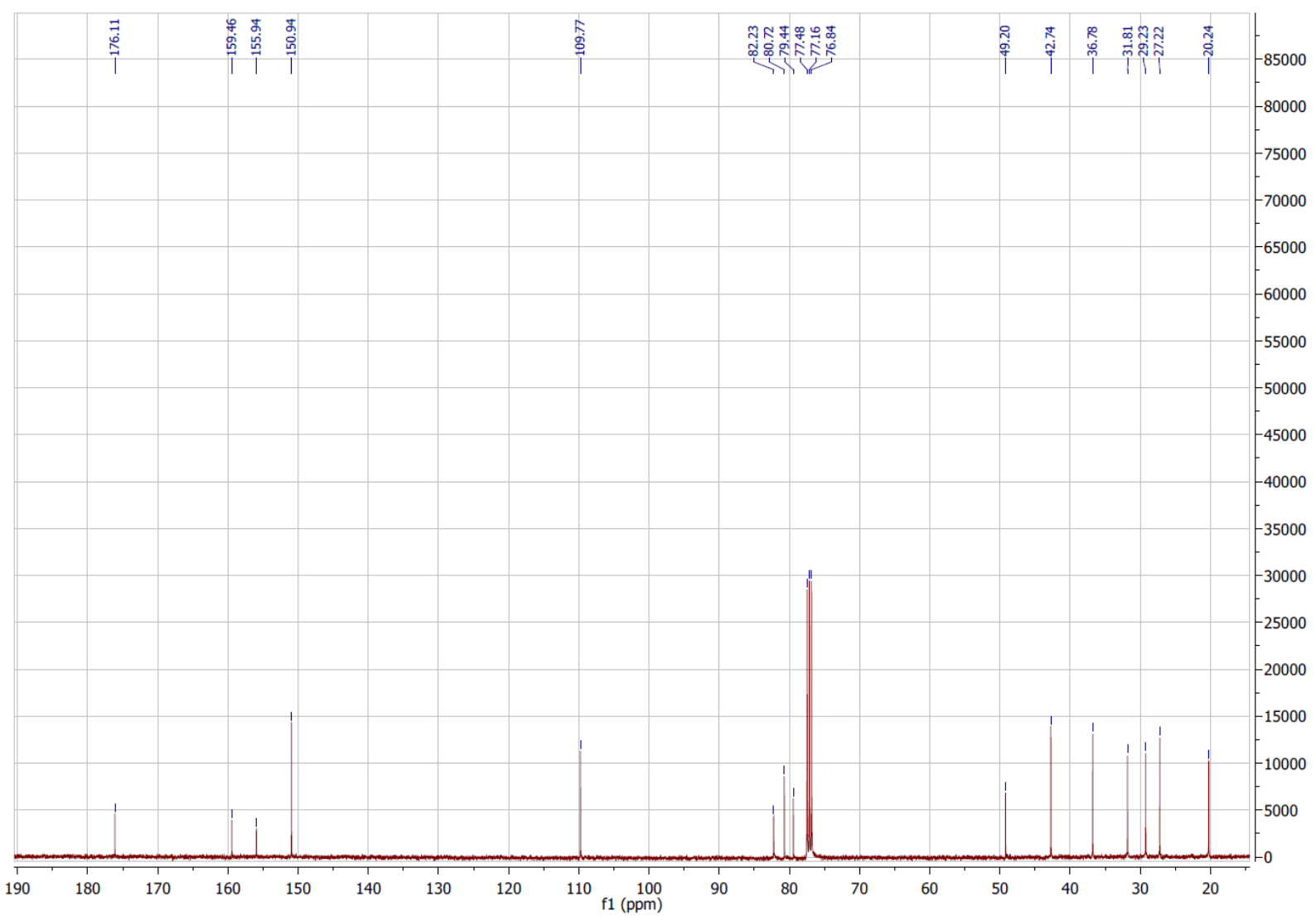


${ }^{1} \mathrm{H}$ NMR of $20 \mathrm{~g}$ in $\mathrm{CDCl}_{3}(600 \mathrm{MHz})$

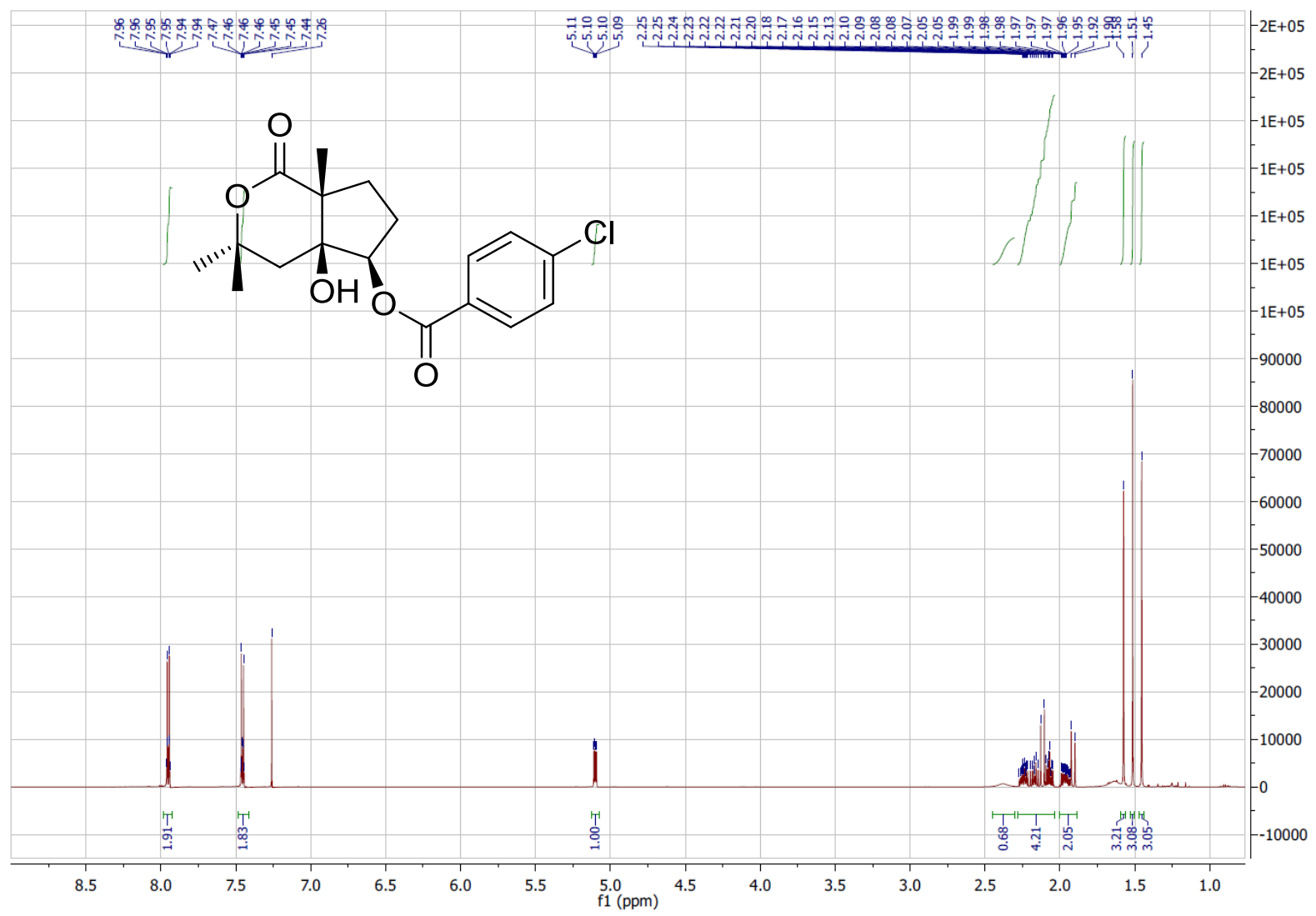

${ }^{13} \mathrm{C}$ NMR of $20 \mathrm{~g}$ in $\mathrm{CDCl}_{3}(151 \mathrm{MHz})$

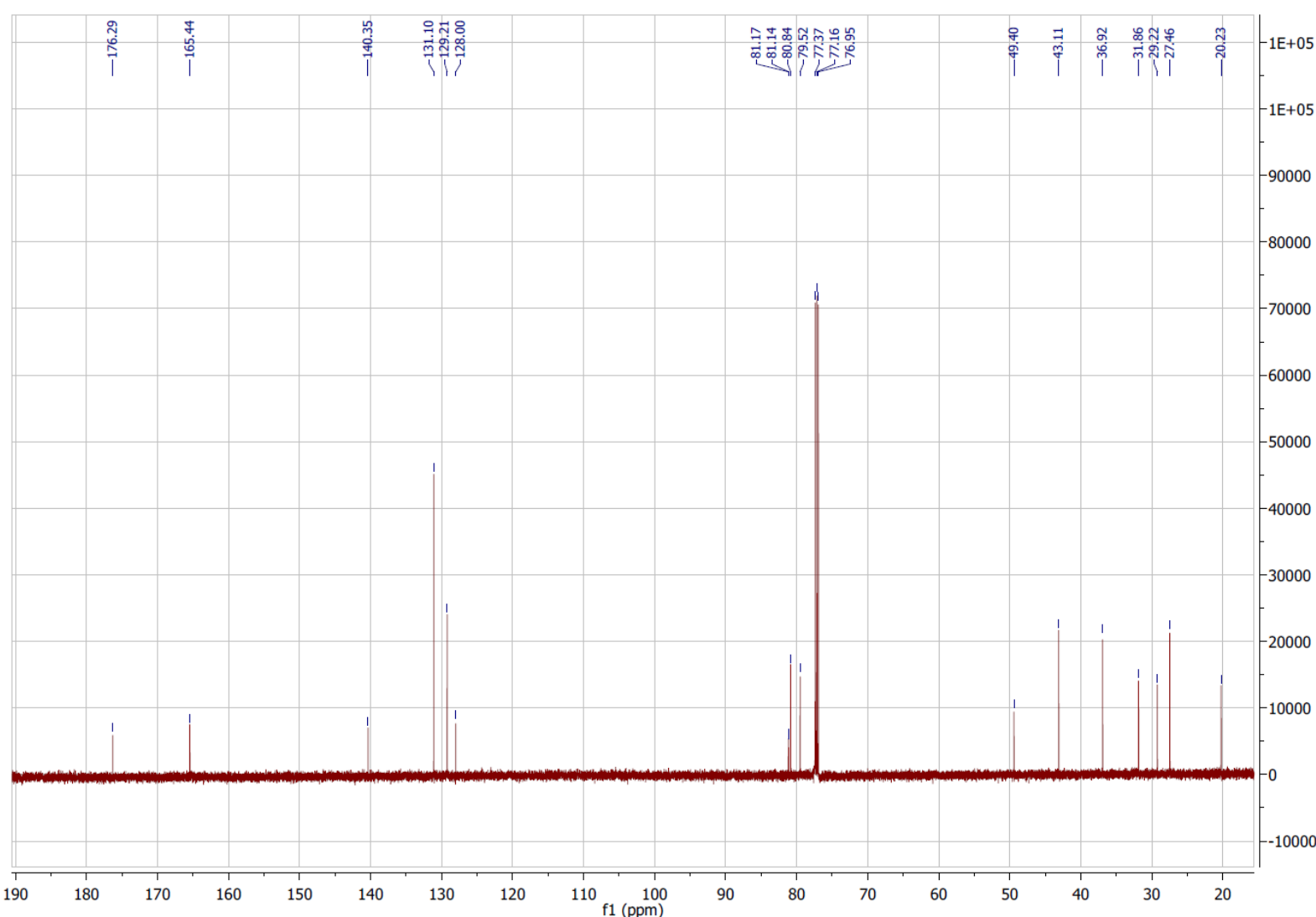


${ }^{1} \mathrm{H}$ NMR of 20h in $\mathrm{CDCl}_{3}(600 \mathrm{MHz})$

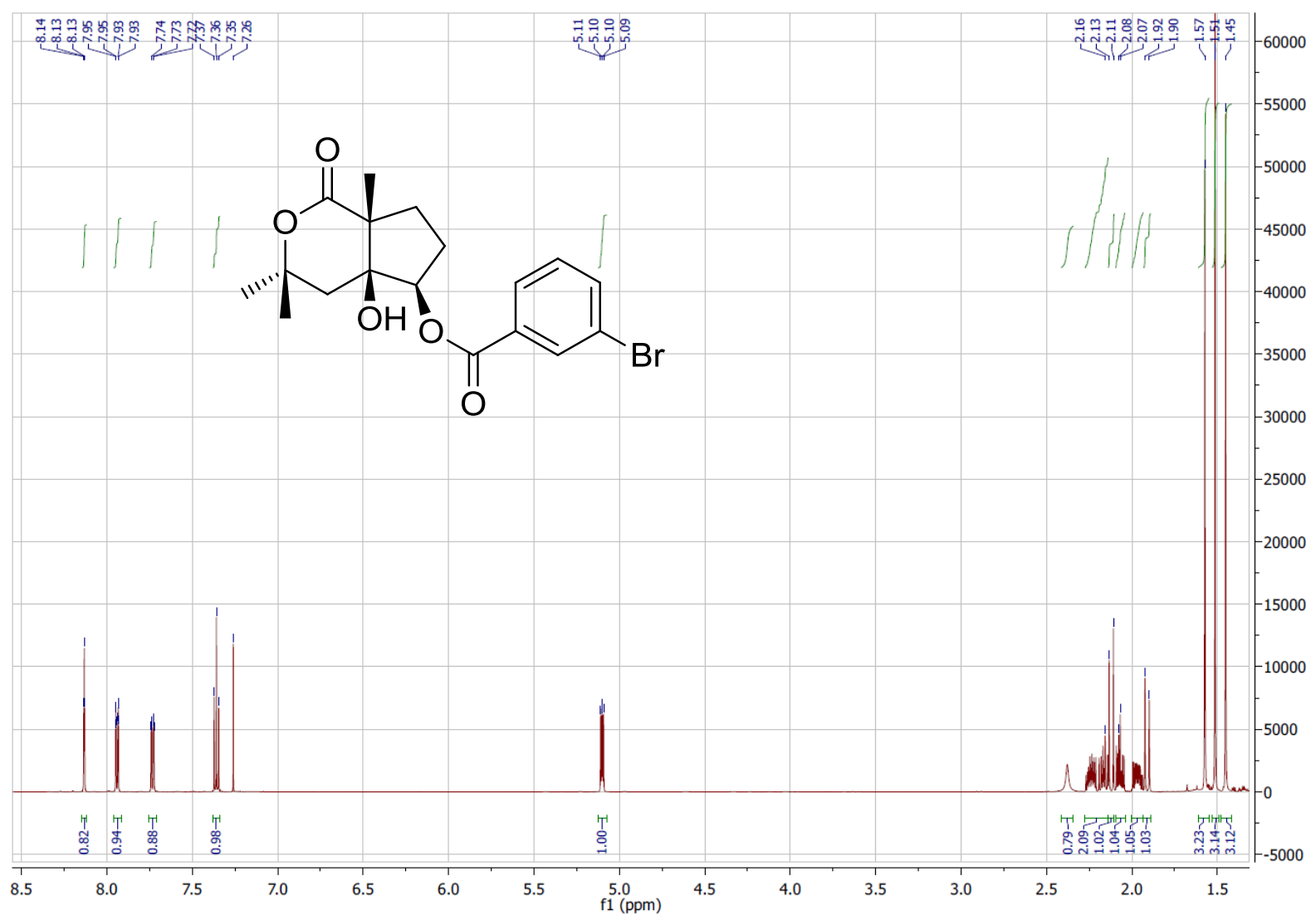

${ }^{13} \mathrm{C}$ NMR of $20 \mathrm{~h}$ in $\mathrm{CDCl}_{3}(151 \mathrm{MHz})$

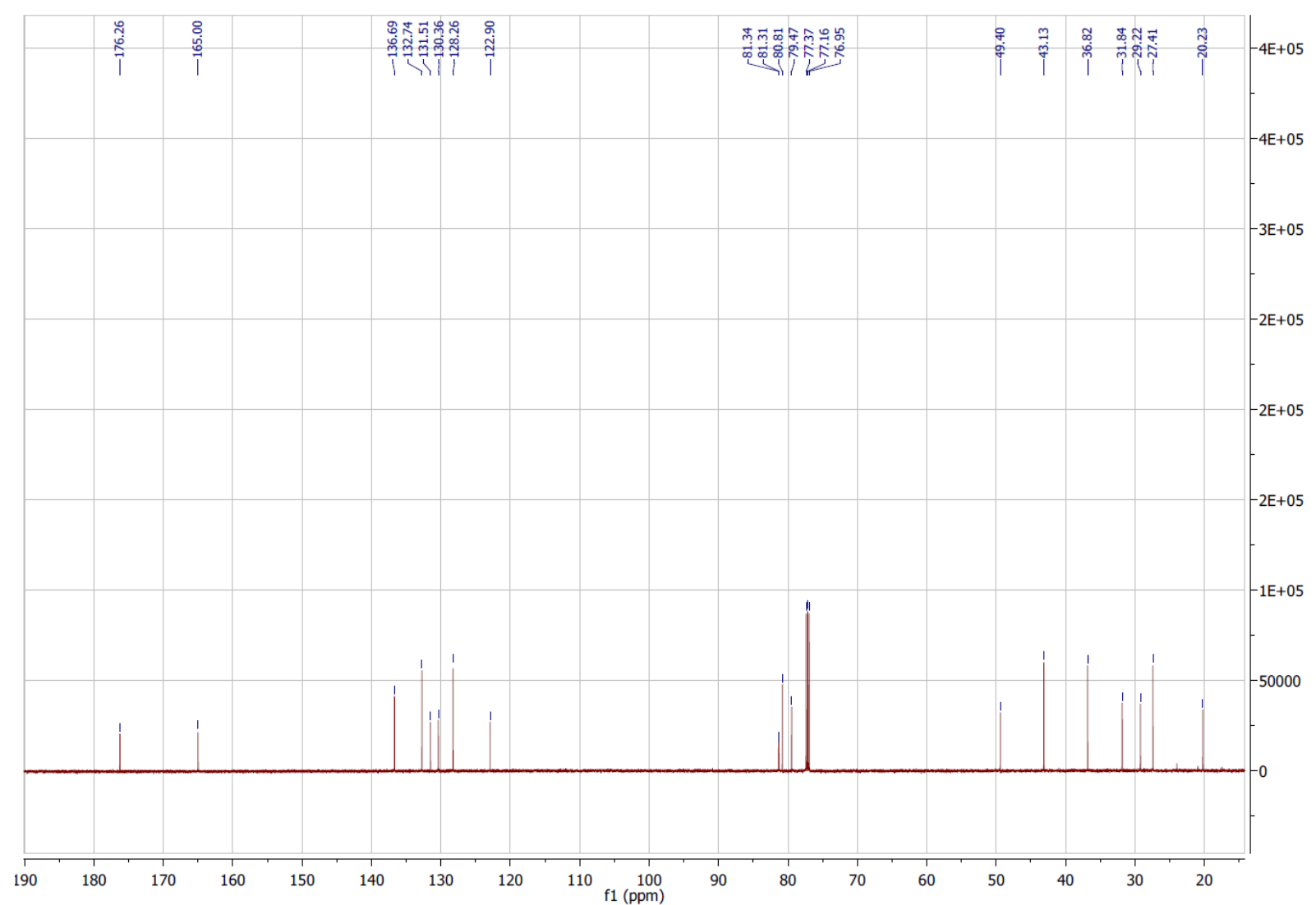


${ }^{1} \mathrm{H}$ NMR of 20i in $\mathrm{CDCl}_{3}(500 \mathrm{MHz})$

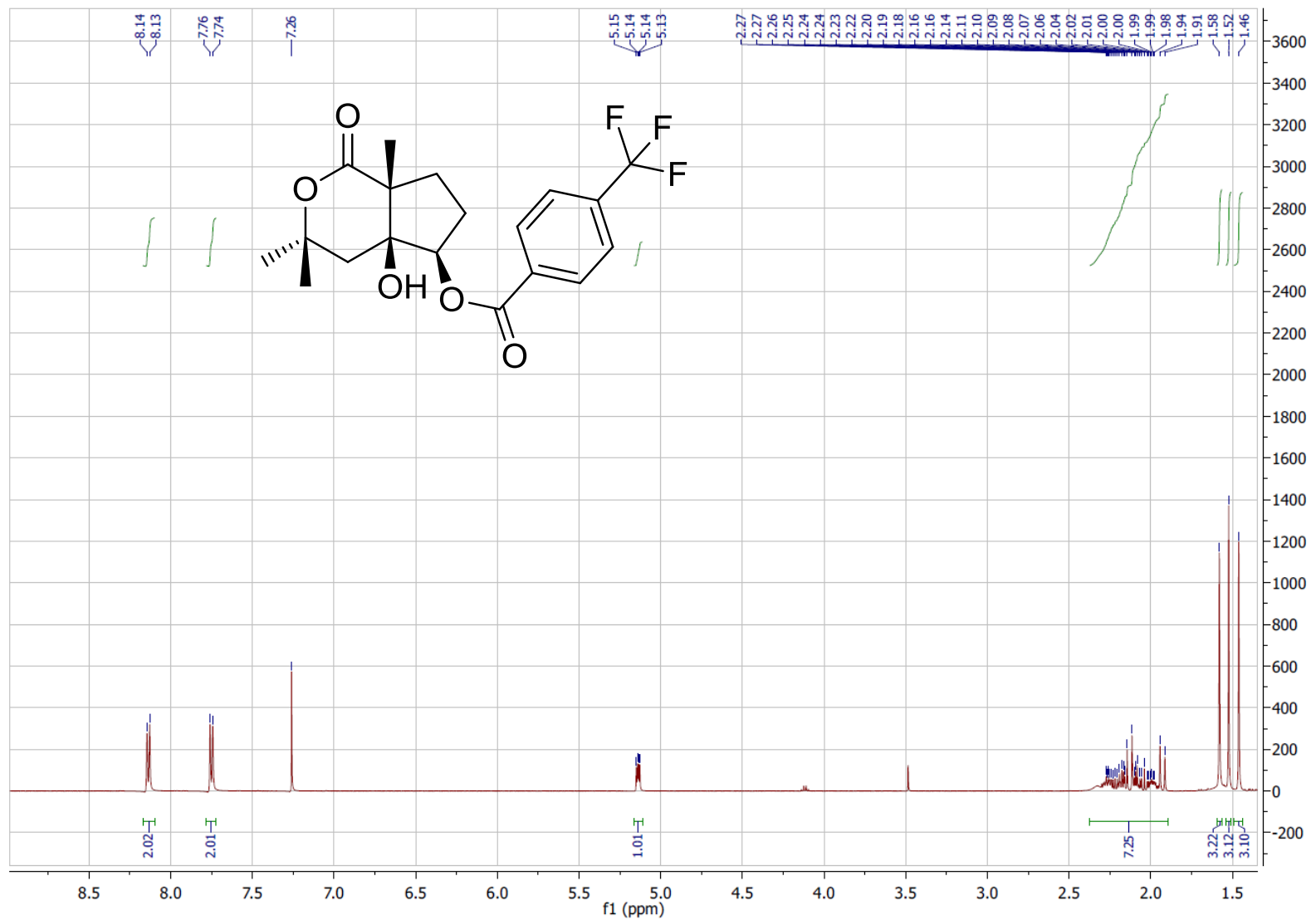

${ }^{13} \mathrm{C}$ NMR of $20 \mathrm{i}$ in $\mathrm{CDCl}_{3}(126 \mathrm{MHz})$

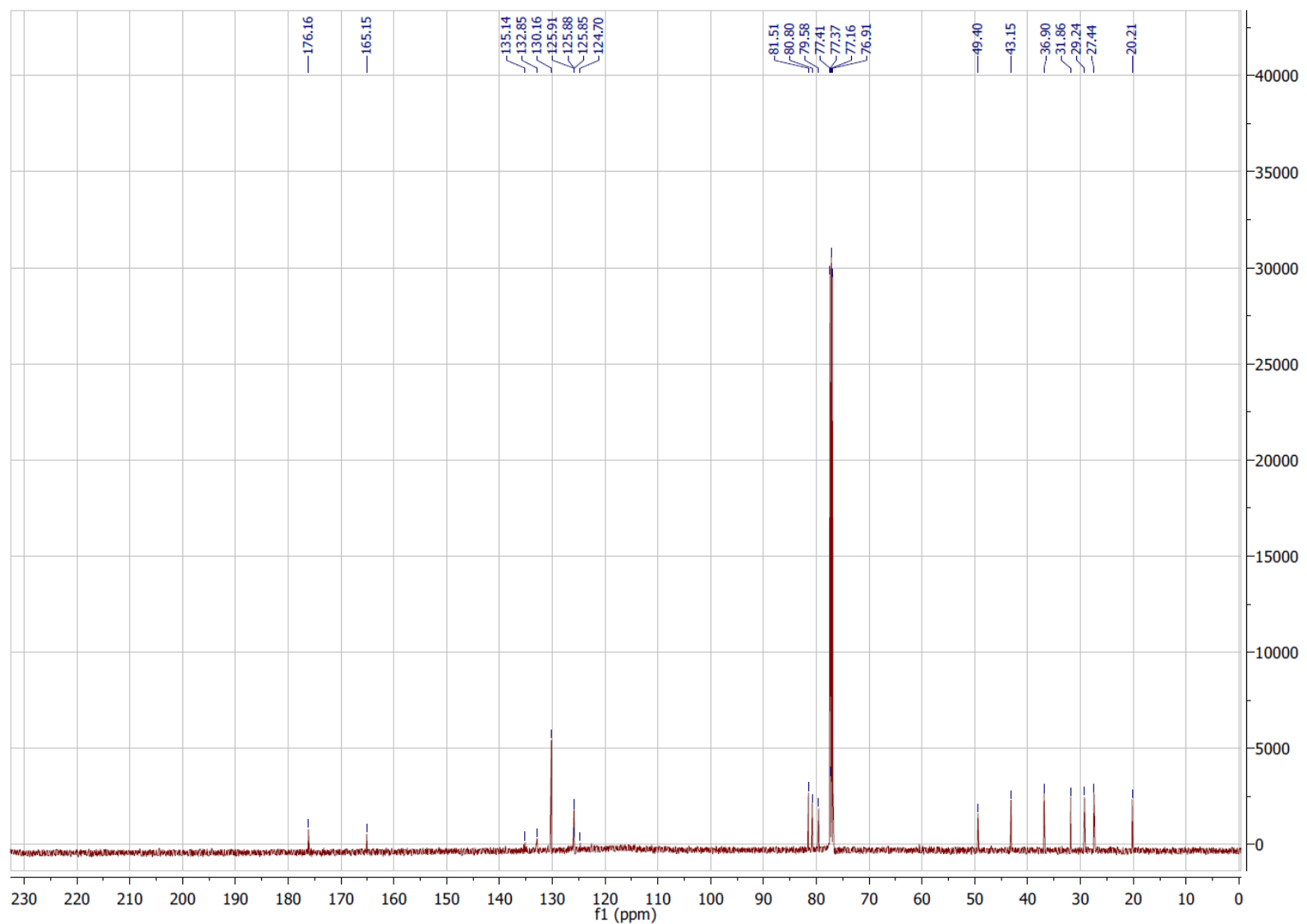


${ }^{1} \mathrm{H}$ NMR of 20 j in $\mathrm{CDCl}_{3}(400 \mathrm{MHz})$

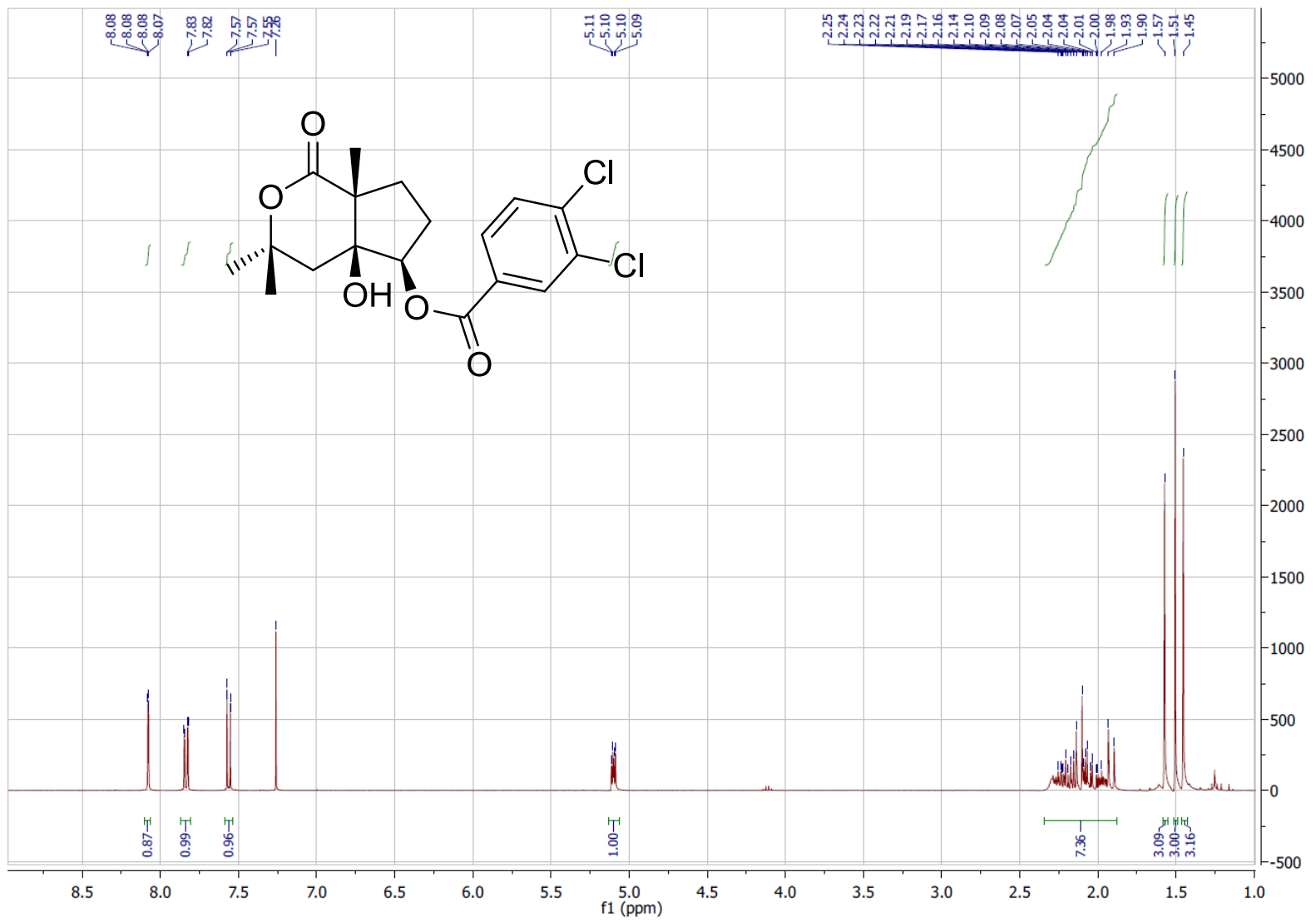

${ }^{13} \mathrm{C}$ NMR of $20 \mathbf{j}$ in $\mathrm{CDCl}_{3}(101 \mathrm{MHz})$

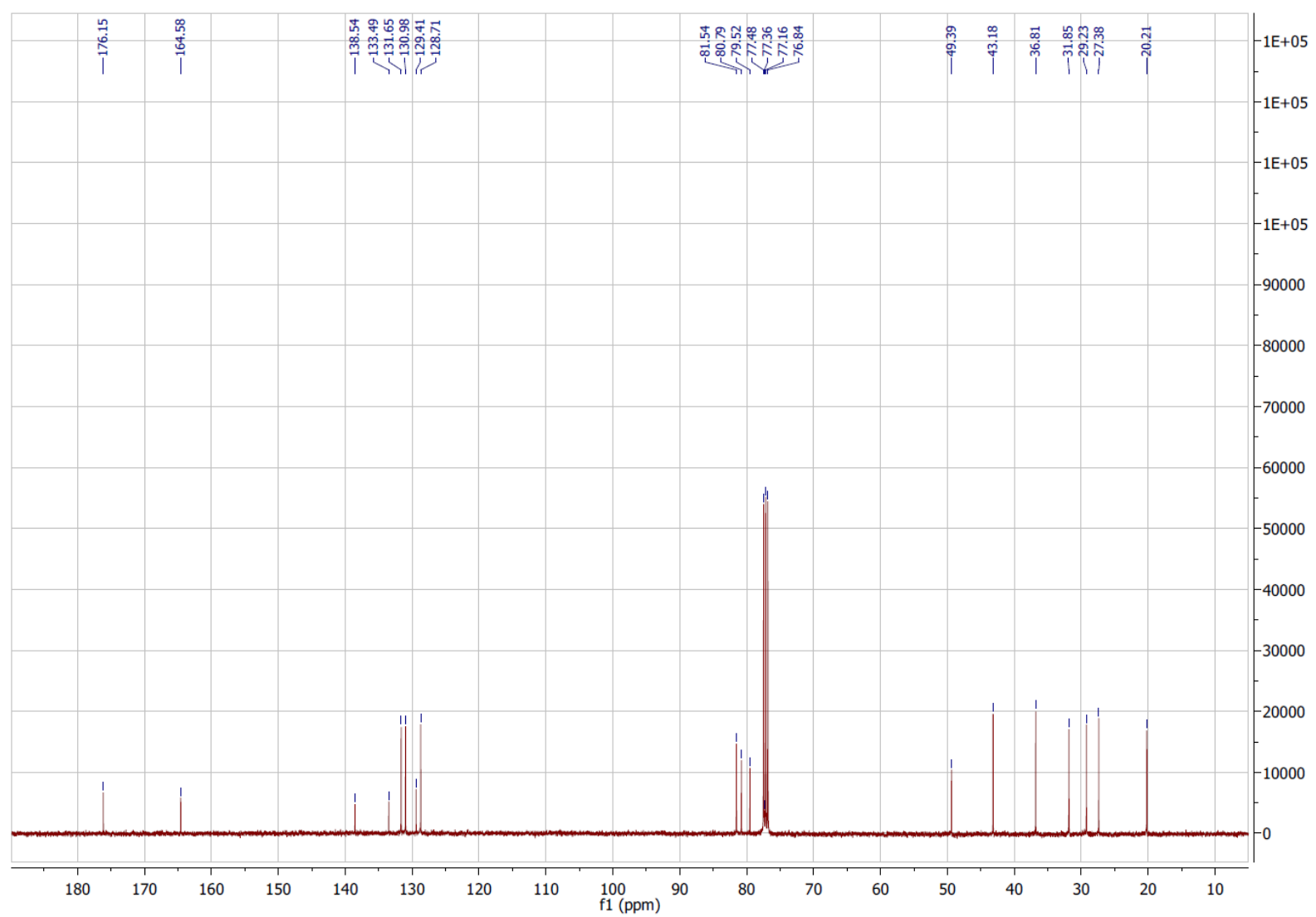


${ }^{1} \mathrm{H} \mathrm{NMR}$ of 20k in $\mathrm{CDCl}_{3}(600 \mathrm{MHz})$

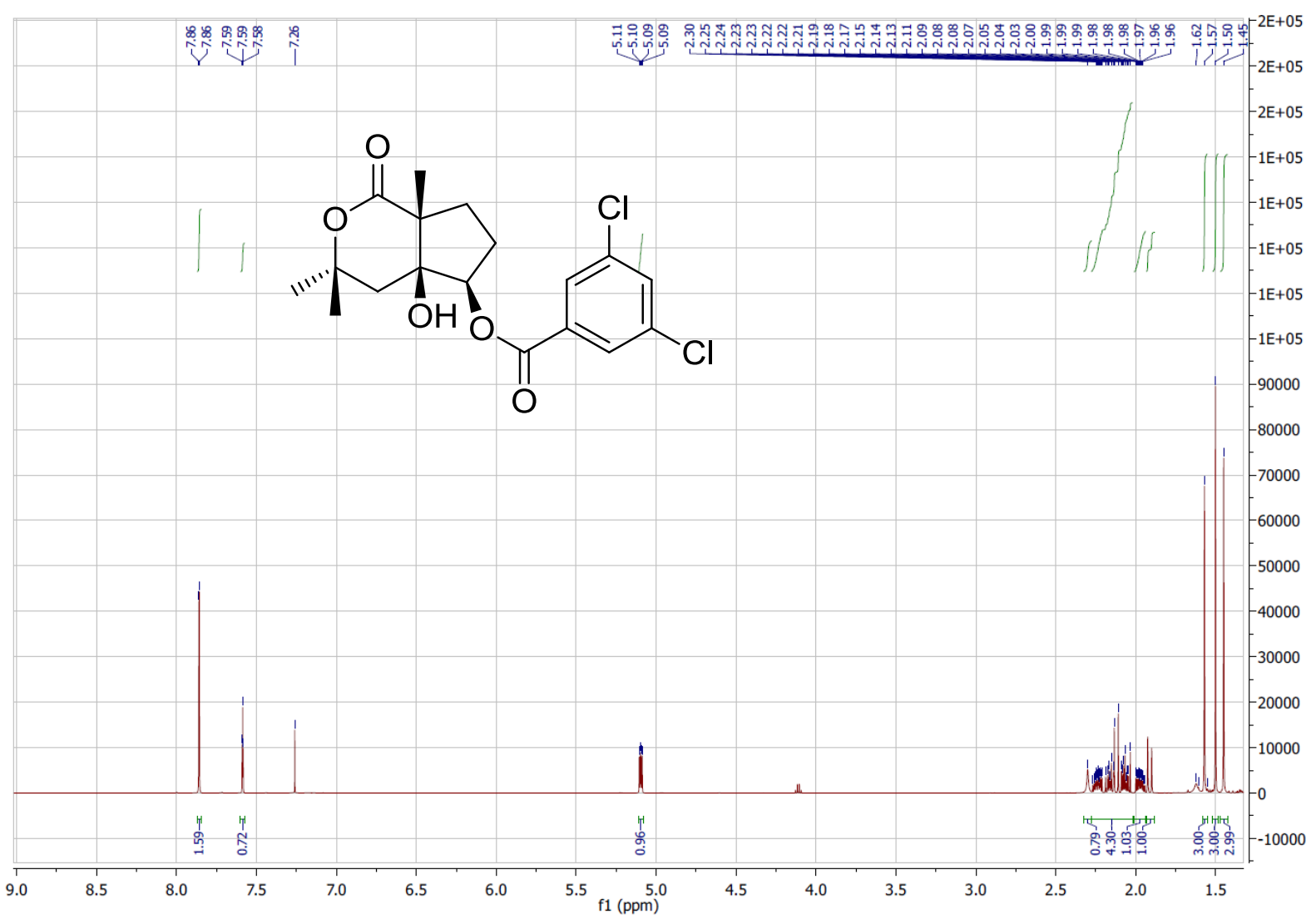

${ }^{13} \mathrm{C}$ NMR of 20k in $\mathrm{CDCl}_{3}(151 \mathrm{MHz})$

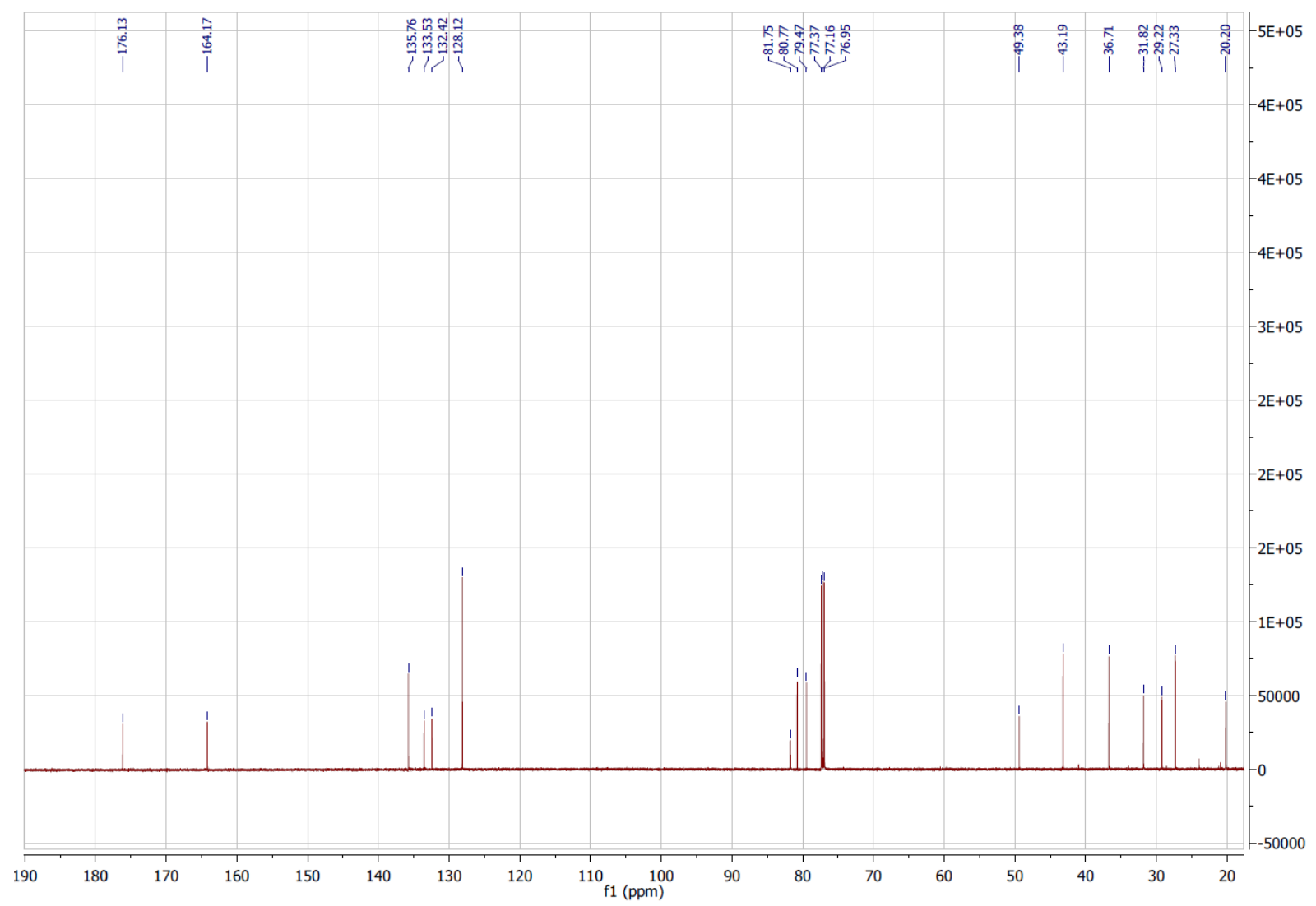


${ }^{1} \mathrm{H}$ NMR of 201 in $\mathrm{CDCl}_{3}(600 \mathrm{MHz})$

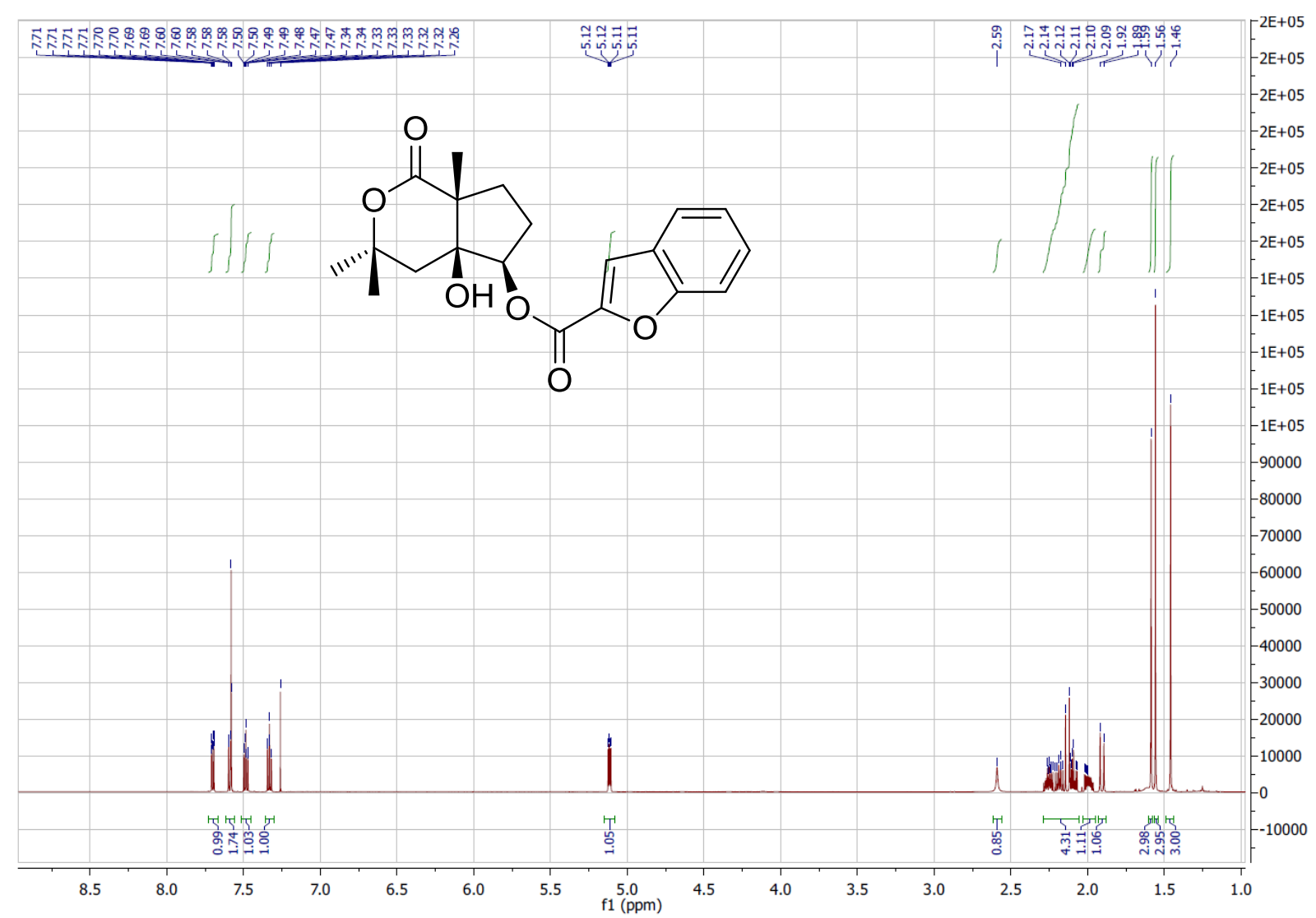

${ }^{13} \mathrm{C}$ NMR of 201 in $\mathrm{CDCl}_{3}(151 \mathrm{MHz})$

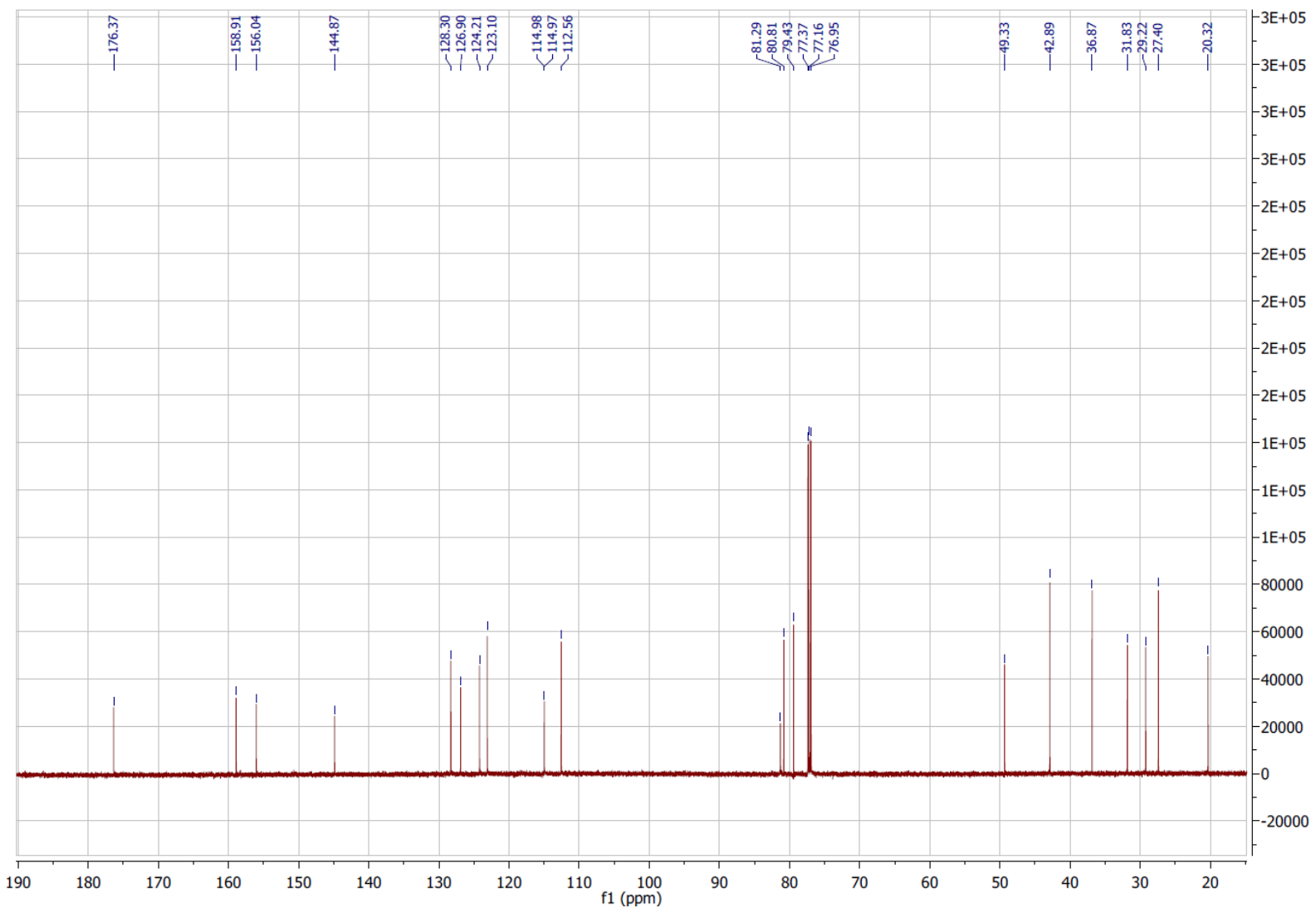


${ }^{1} \mathrm{H}$ NMR of $20 \mathrm{~m}$ in $\mathrm{CDCl}_{3}(600 \mathrm{MHz})$

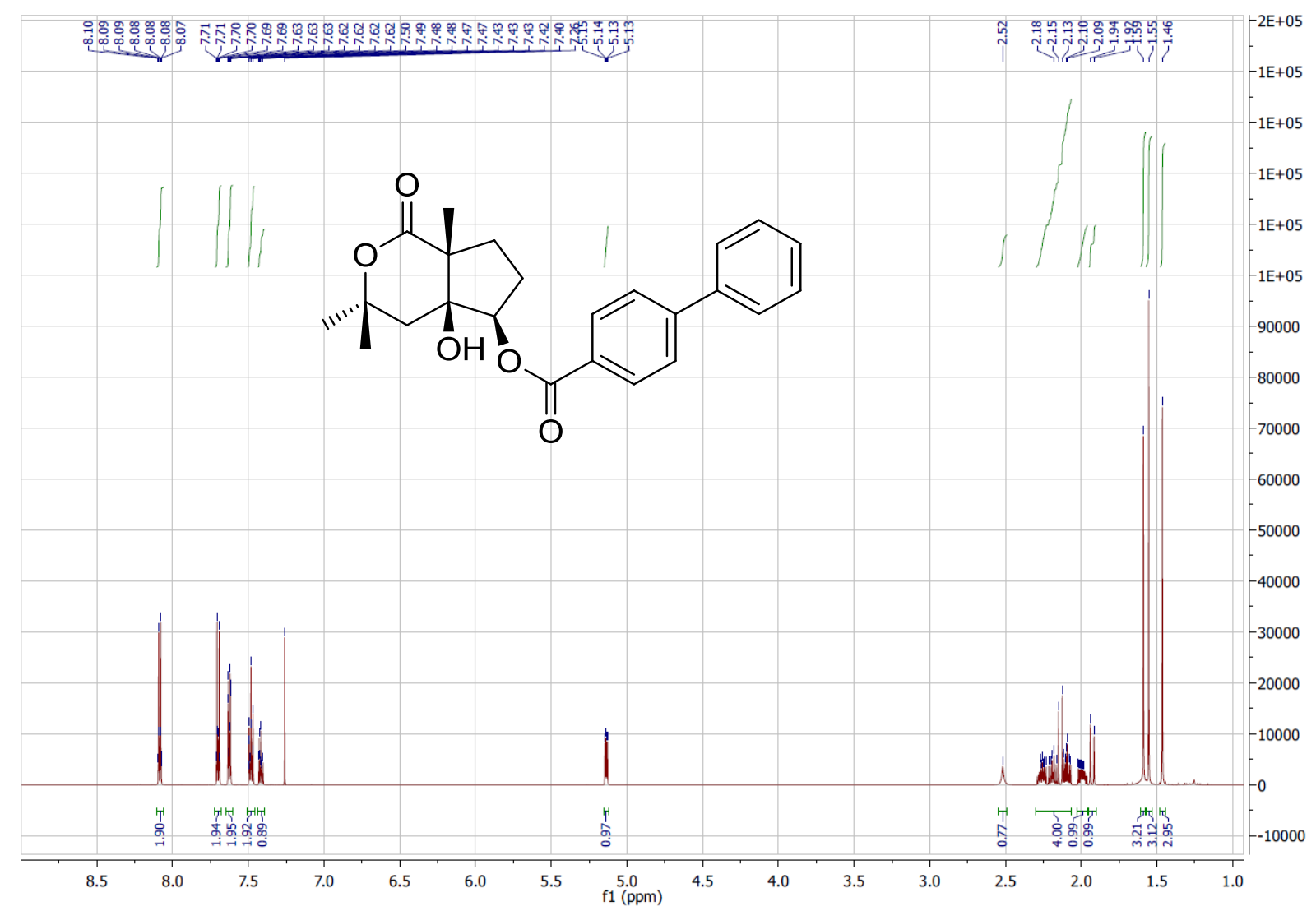

${ }^{13} \mathrm{C}$ NMR of $20 \mathrm{~m}$ in $\mathrm{CDCl}_{3}(151 \mathrm{MHz})$

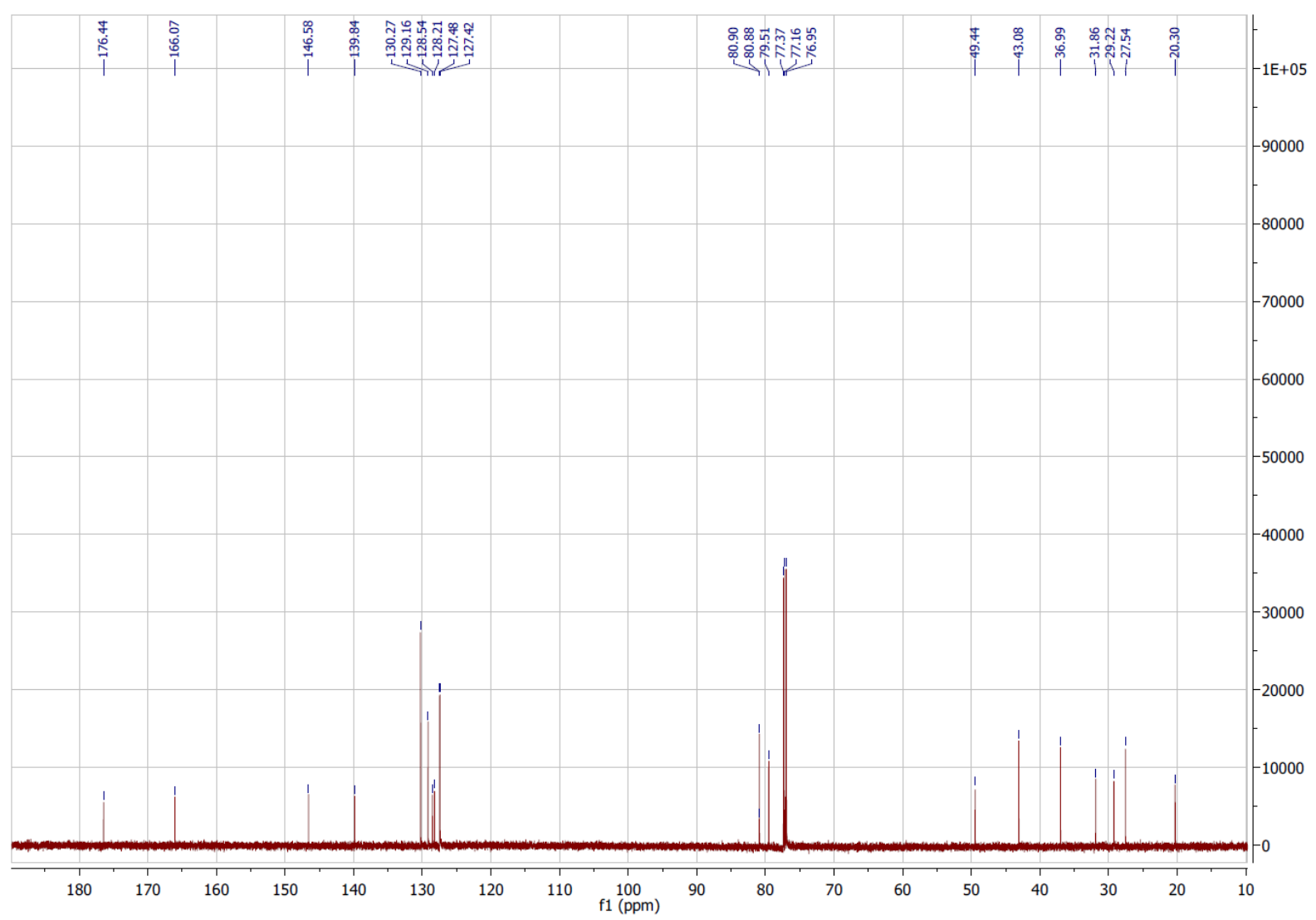


${ }^{1} \mathrm{H} \mathrm{NMR}$ of 20n in $\mathrm{CDCl}_{3}(600 \mathrm{MHz})$

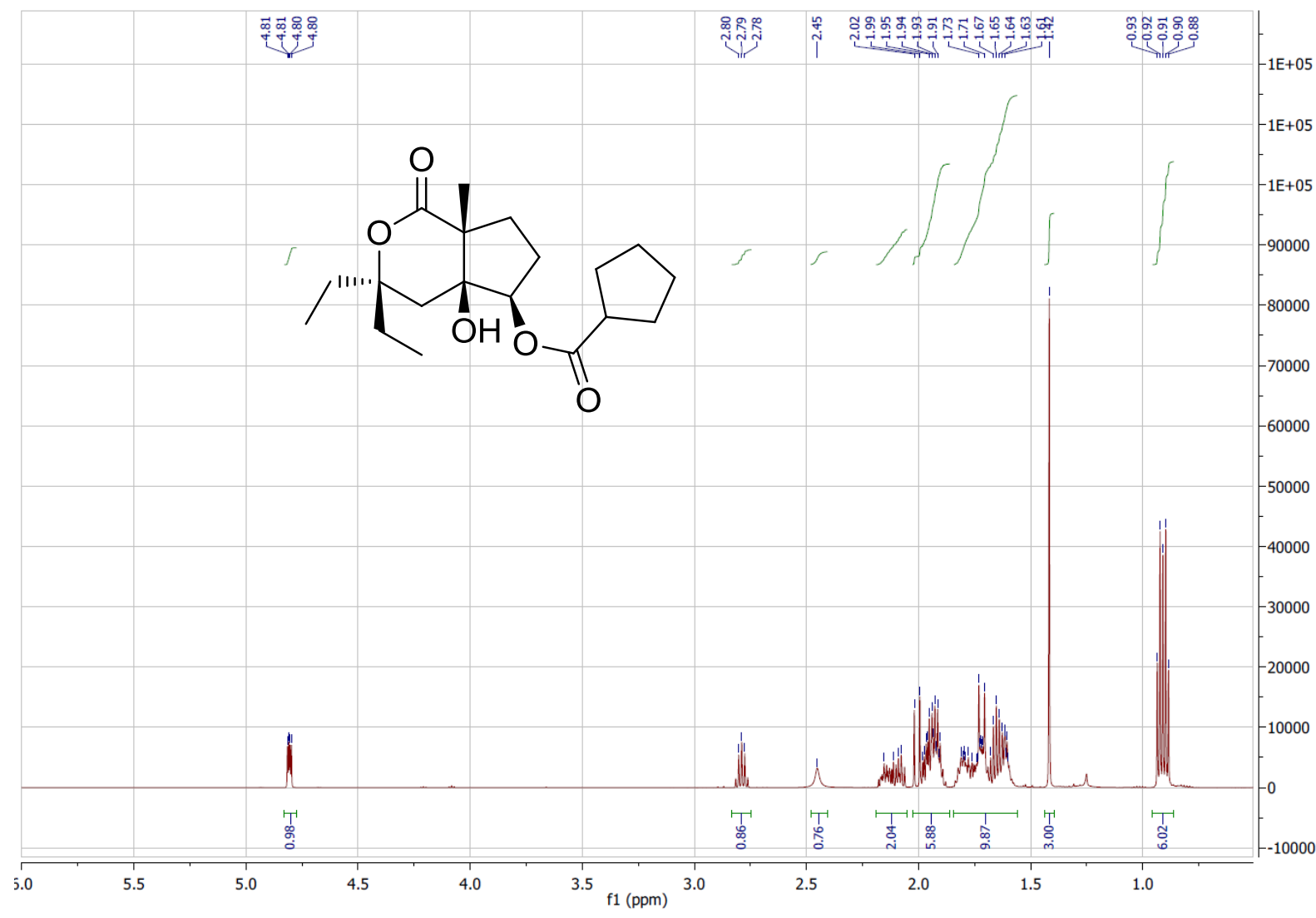

${ }^{13} \mathrm{C}$ NMR of 20n in $\mathrm{CDCl}_{3}(151 \mathrm{MHz})$

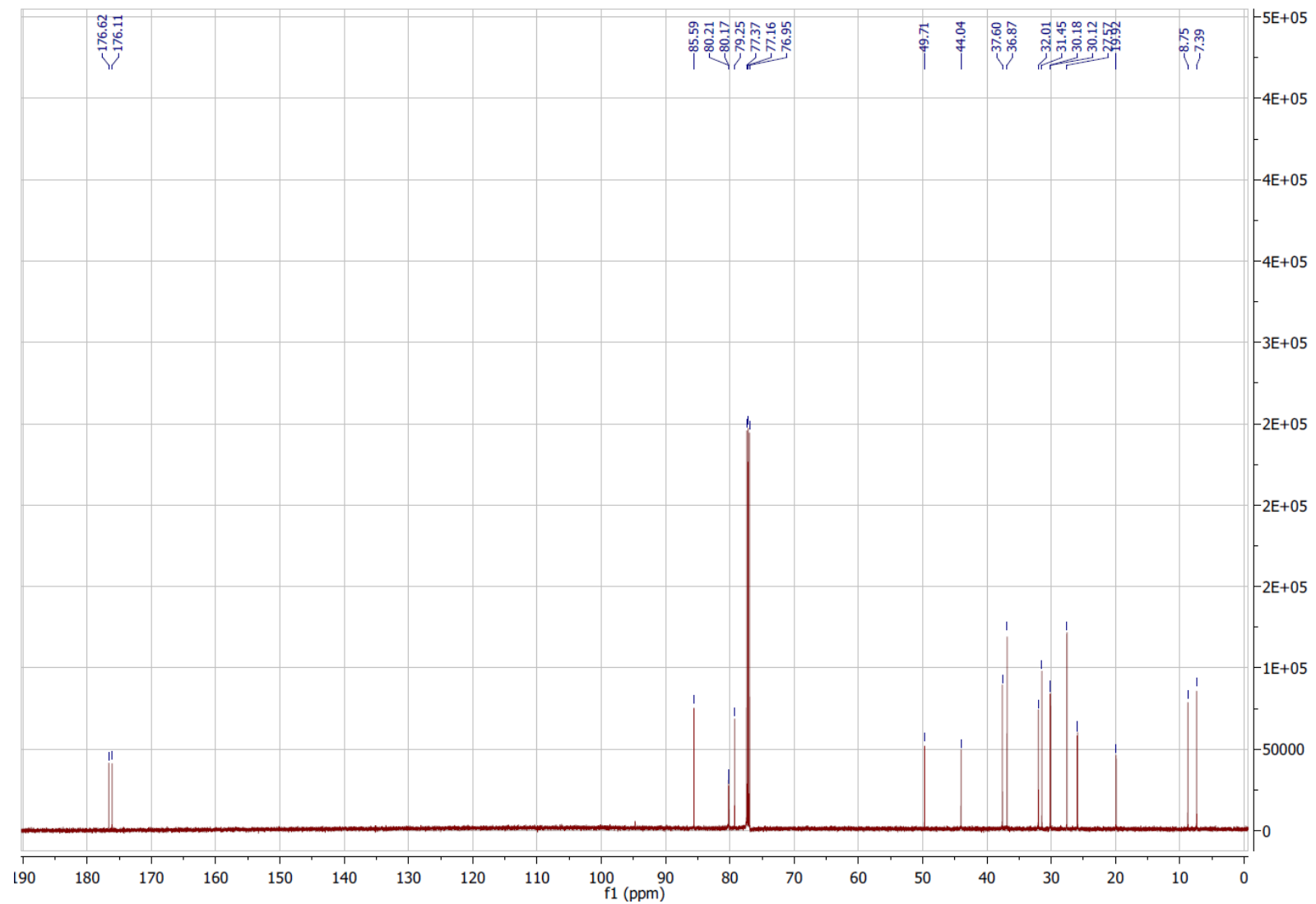


${ }^{1} \mathrm{H}$ NMR of 200 in $\mathrm{CDCl}_{3}(600 \mathrm{MHz})$

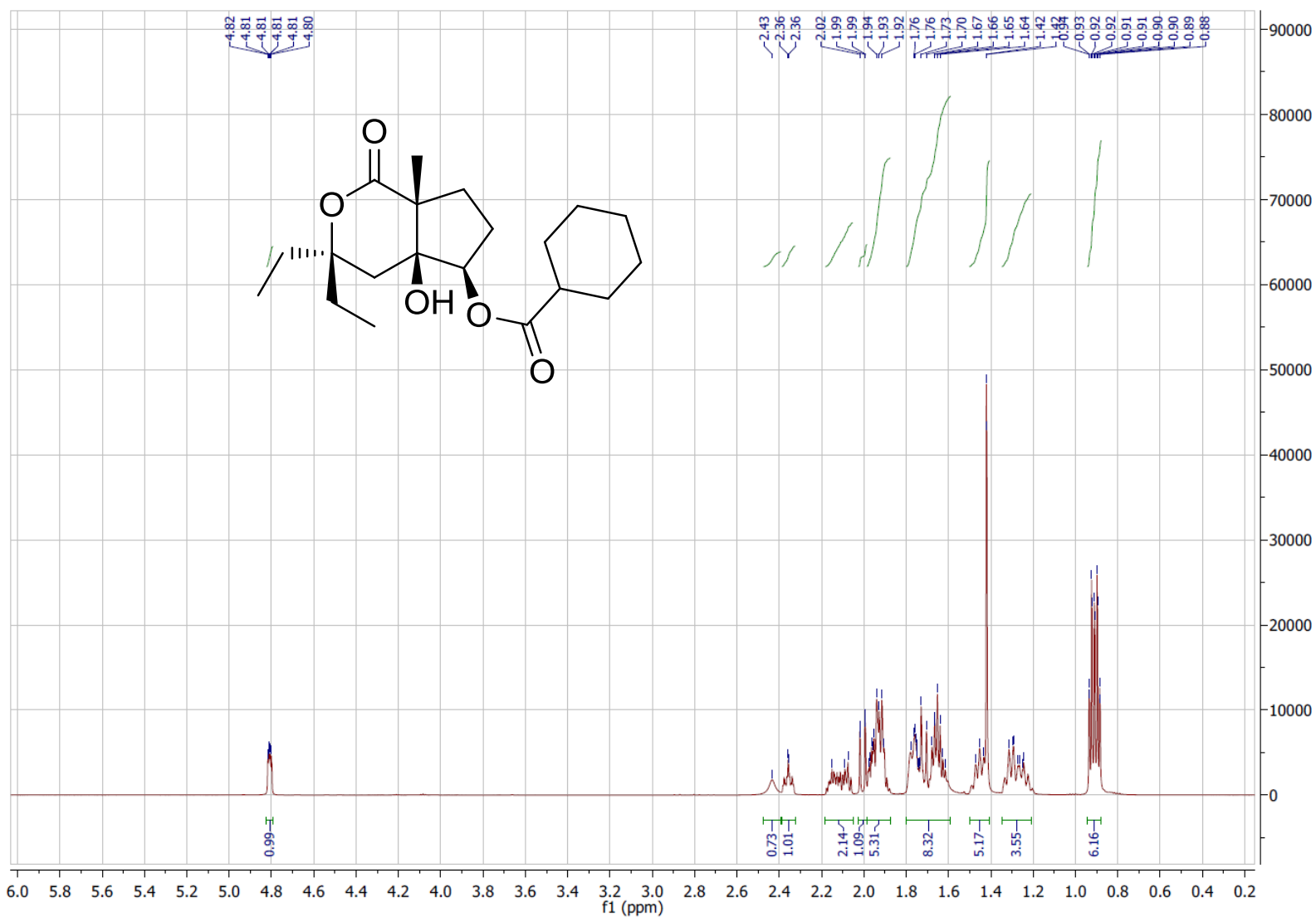

${ }^{13} \mathrm{C}$ NMR of 200 in $\mathrm{CDCl}_{3}(151 \mathrm{MHz})$

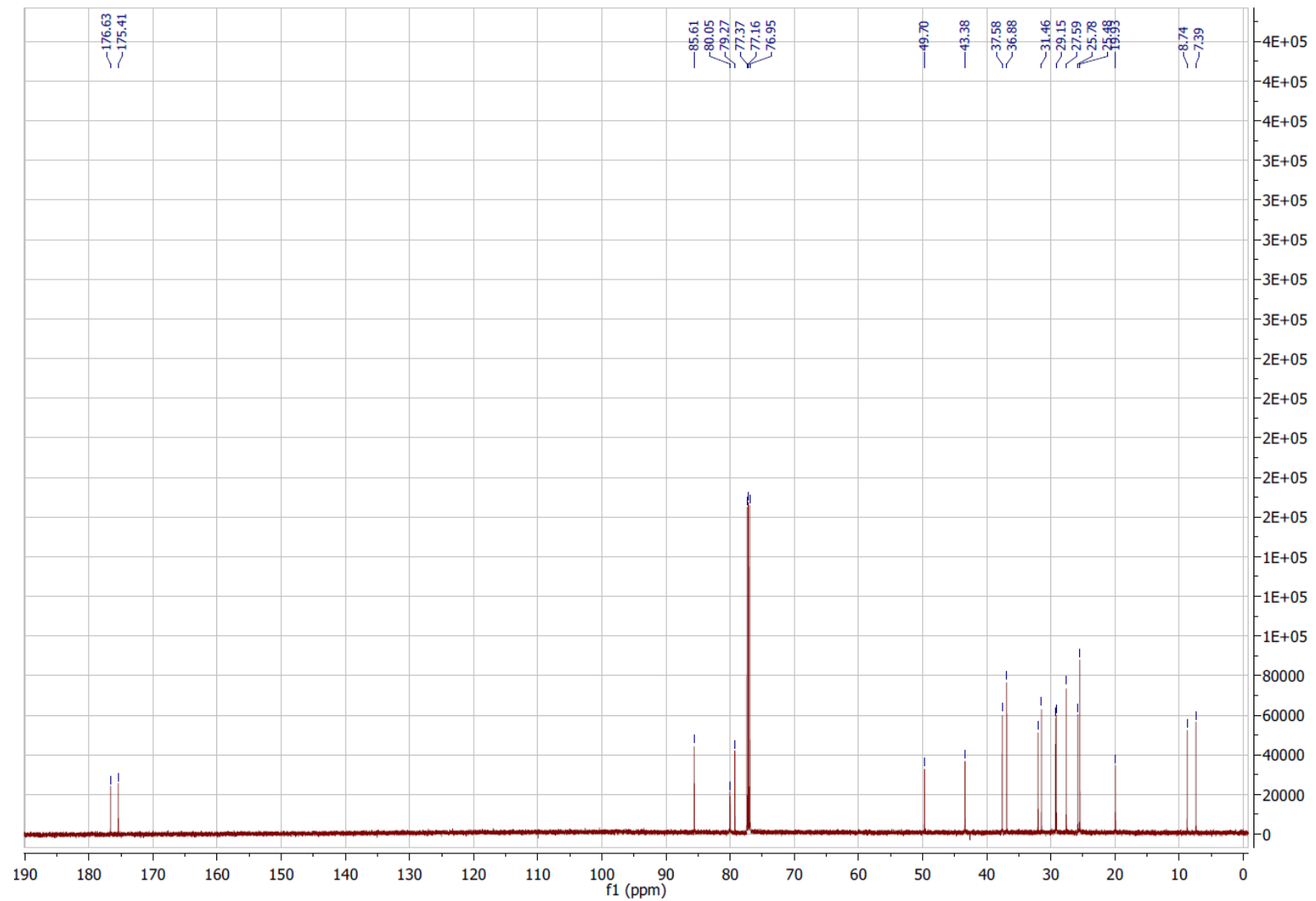


${ }^{1} \mathrm{H}$ NMR of 20p in $\mathrm{CDCl}_{3}(600 \mathrm{MHz})$

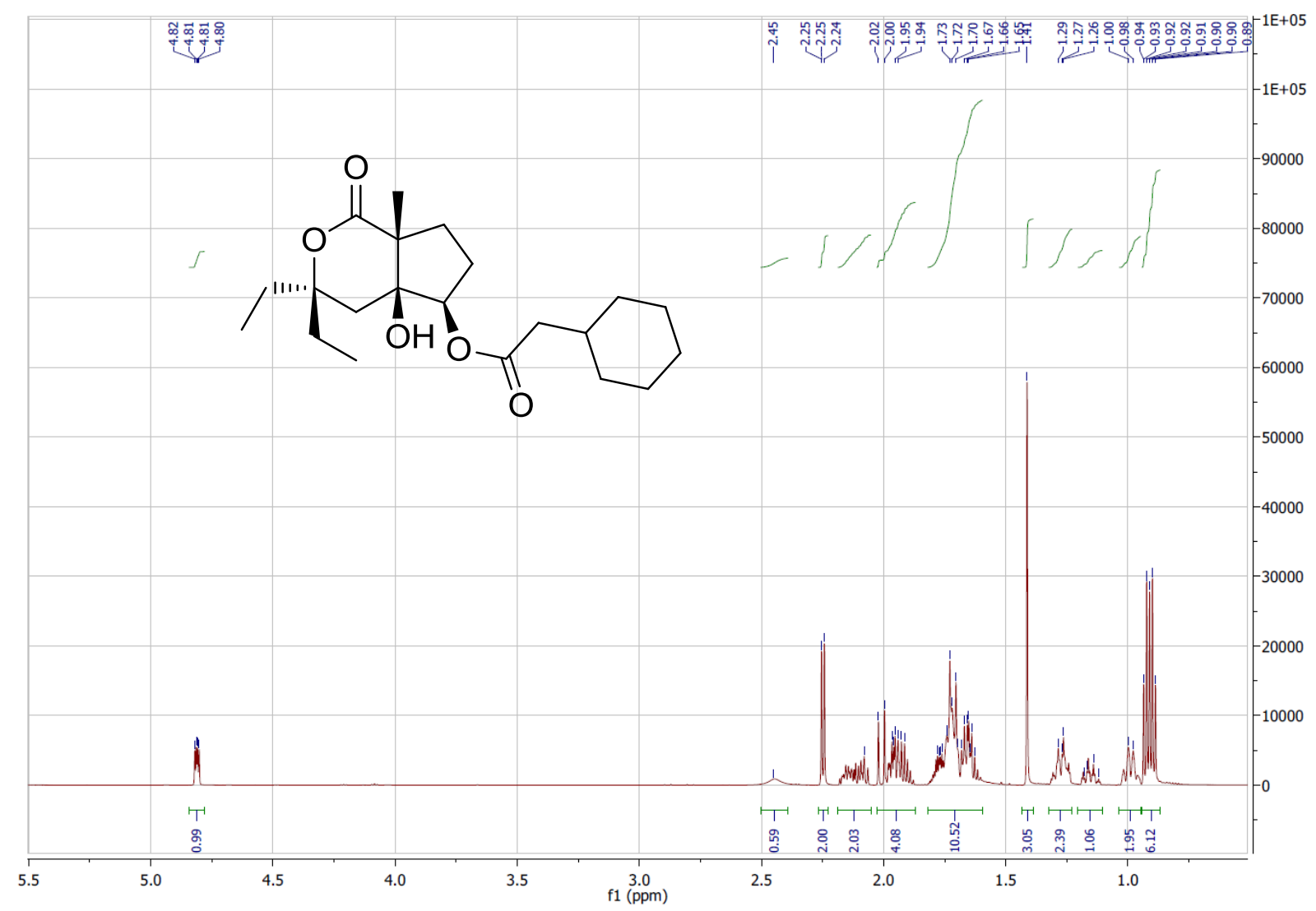

${ }^{13} \mathrm{C}$ NMR of 20p in $\mathrm{CDCl}_{3}(151 \mathrm{MHz})$

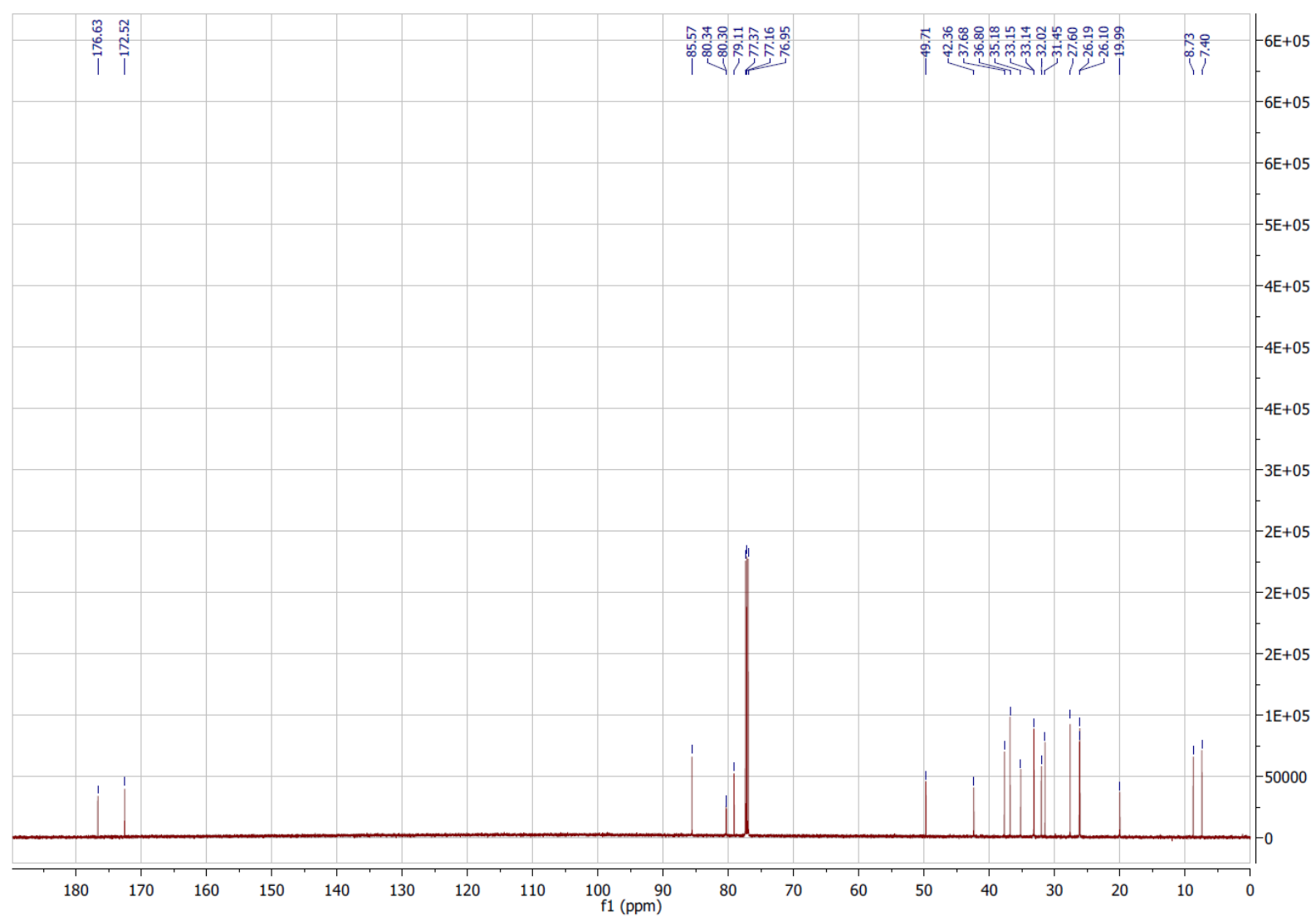


${ }^{1} \mathrm{H}$ NMR of 20q in $\mathrm{CDCl}_{3}(400 \mathrm{MHz})$

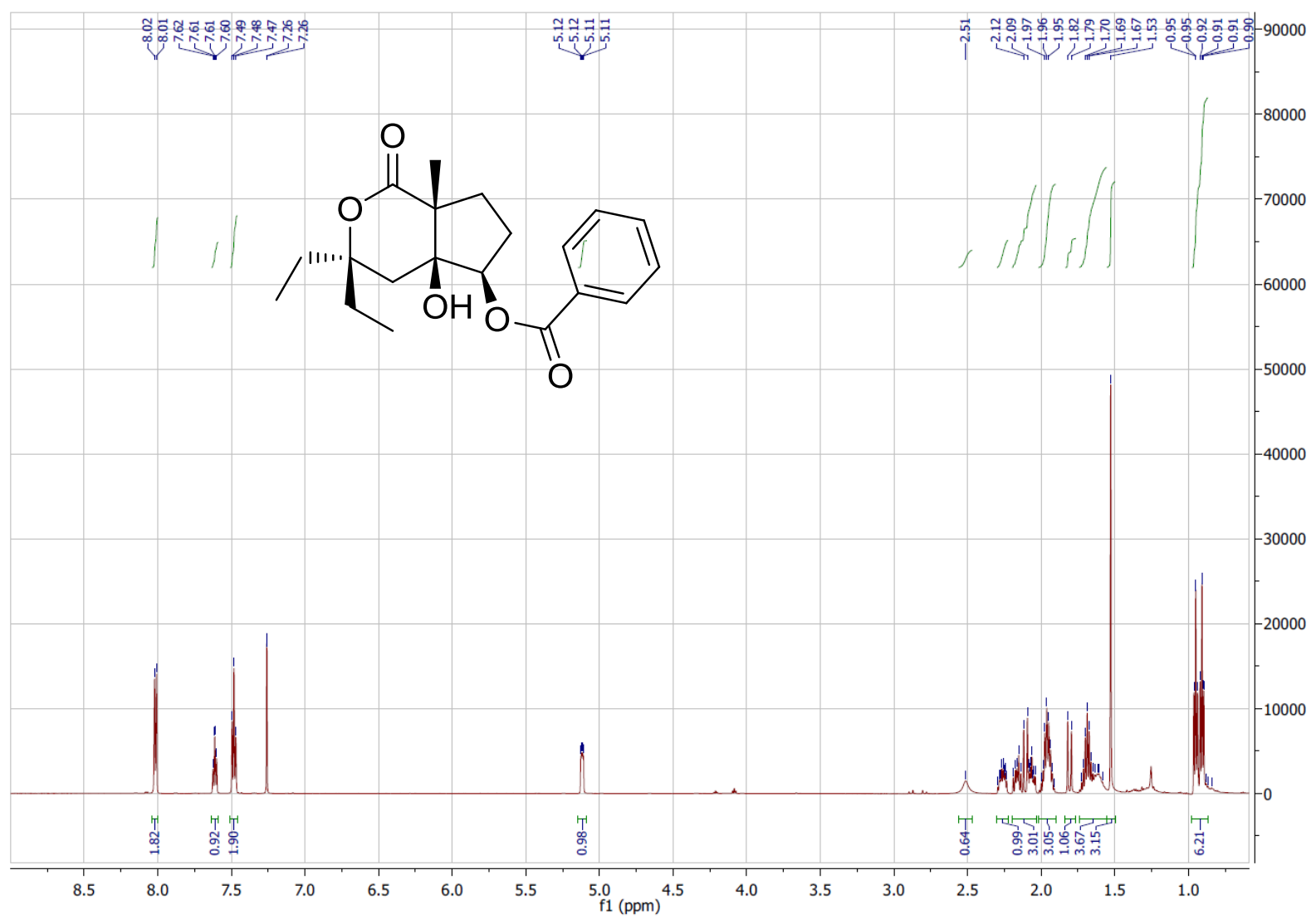

${ }^{13} \mathrm{C}$ NMR of 20q in $\mathrm{CDCl}_{3}(101 \mathrm{MHz})$

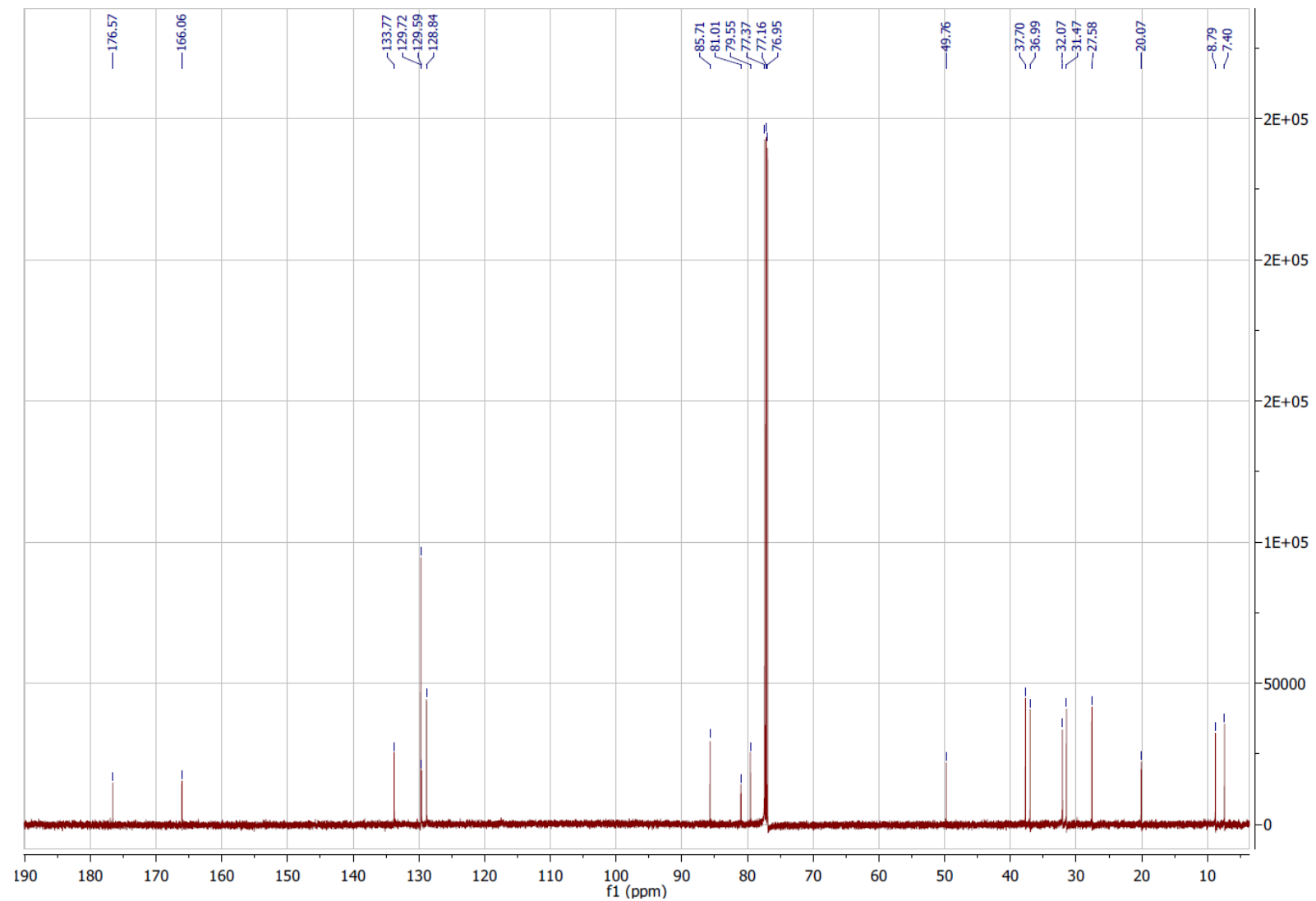


${ }^{1} \mathrm{H}$ NMR of 20r in $\mathrm{CDCl}_{3}(500 \mathrm{MHz})$

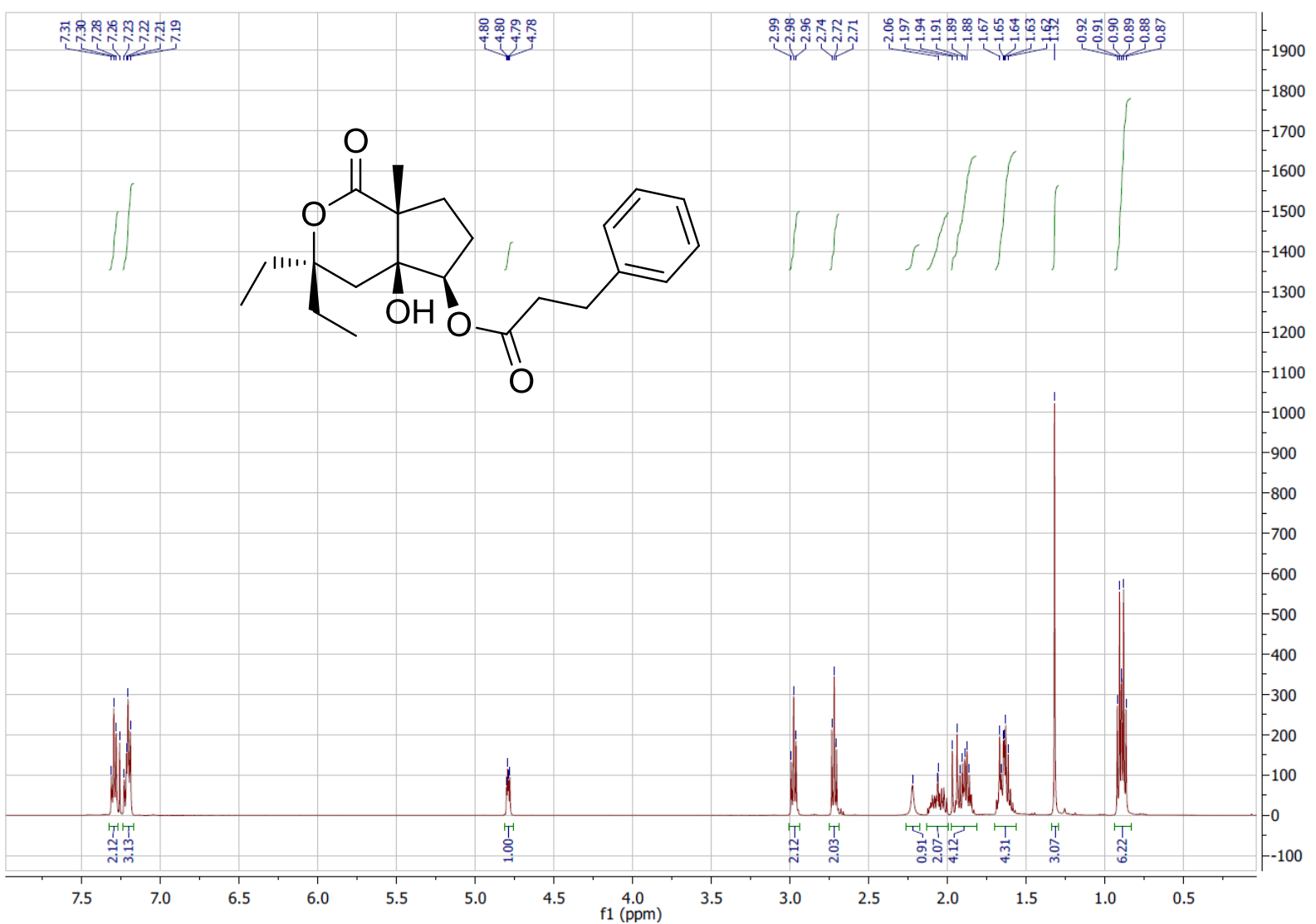

${ }^{13} \mathrm{C}$ NMR of 20r in $\mathrm{CDCl}_{3}(126 \mathrm{MHz})$

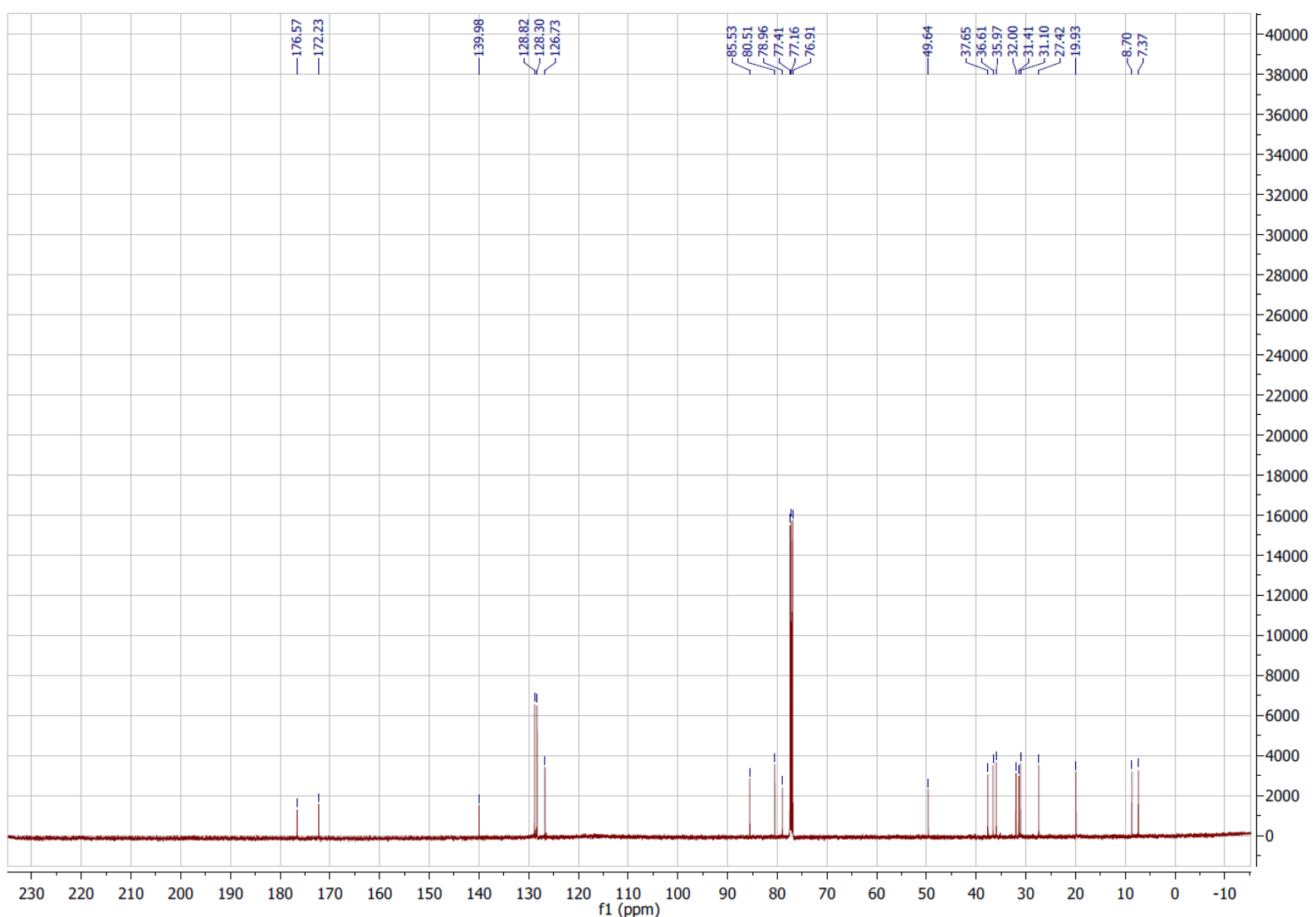


${ }^{1} \mathrm{H}$ NMR of 20s in $\mathrm{CDCl}_{3}(600 \mathrm{MHz})$

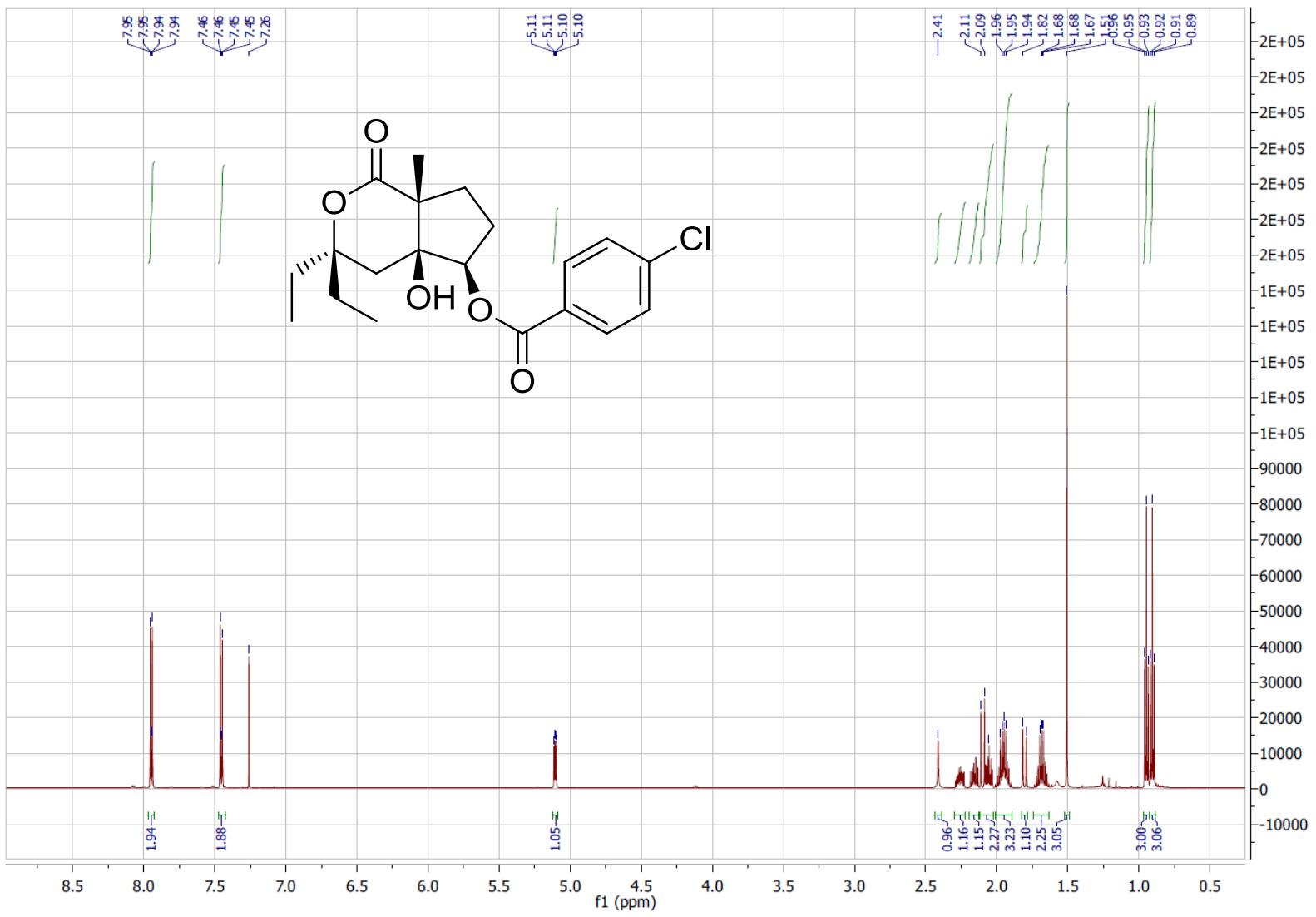

${ }^{13} \mathrm{C}$ NMR of 20s in $\mathrm{CDCl}_{3}(151 \mathrm{MHz})$

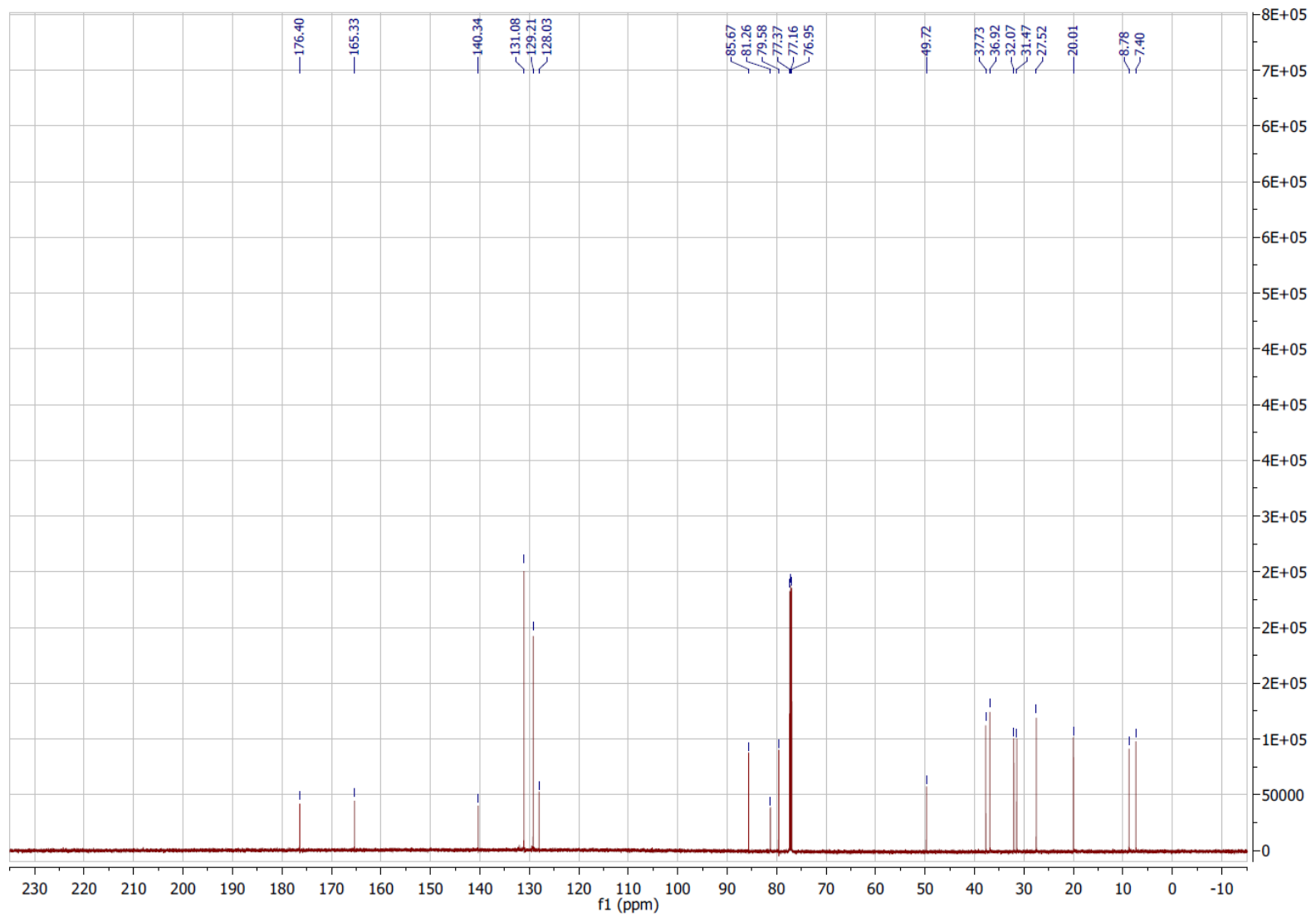


${ }^{1} \mathrm{H}$ NMR of 20t in $\mathrm{CDCl}_{3}(600 \mathrm{MHz})$

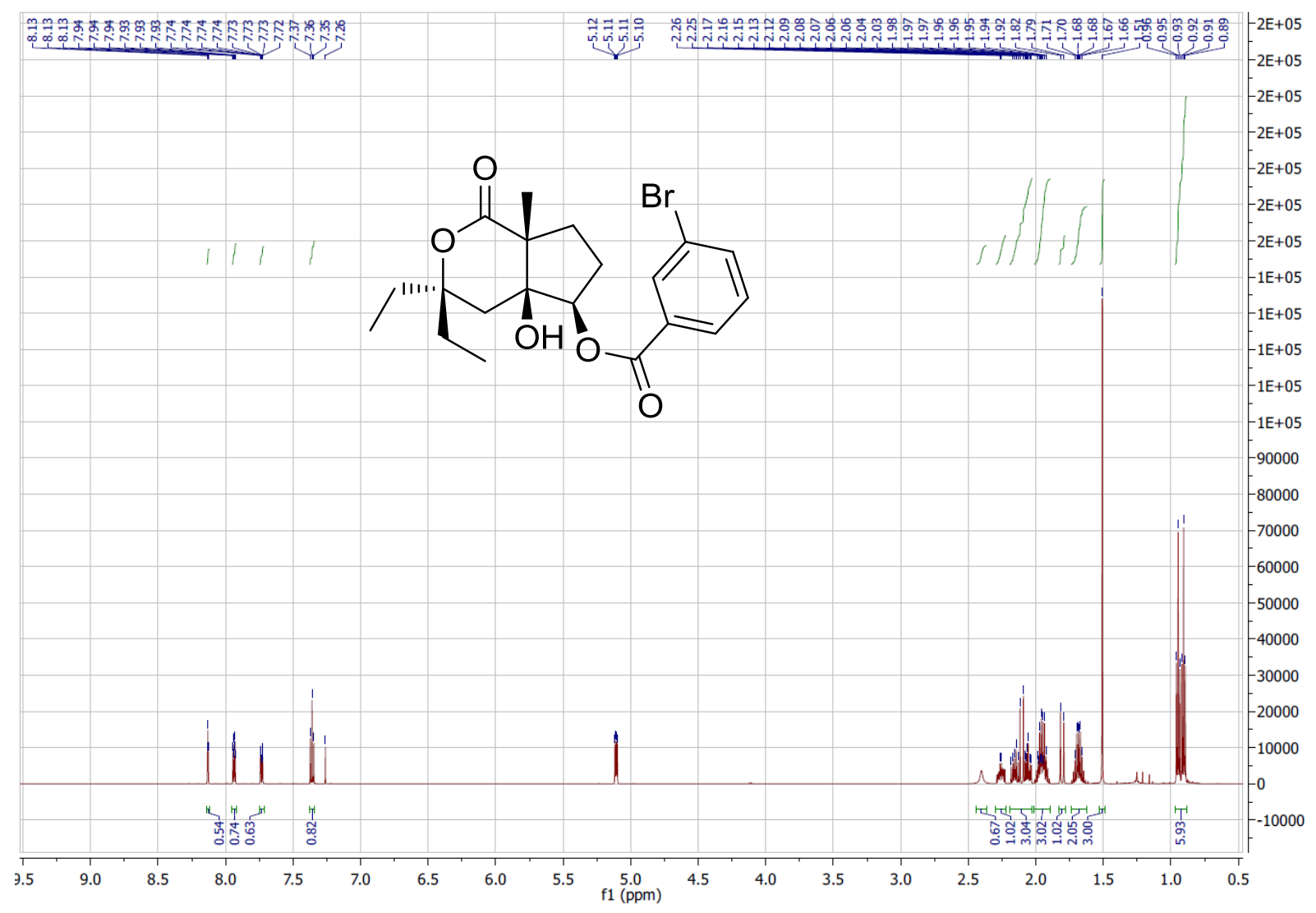

${ }^{13} \mathrm{C}$ NMR of 20t in $\mathrm{CDCl}_{3}(151 \mathrm{MHz})$

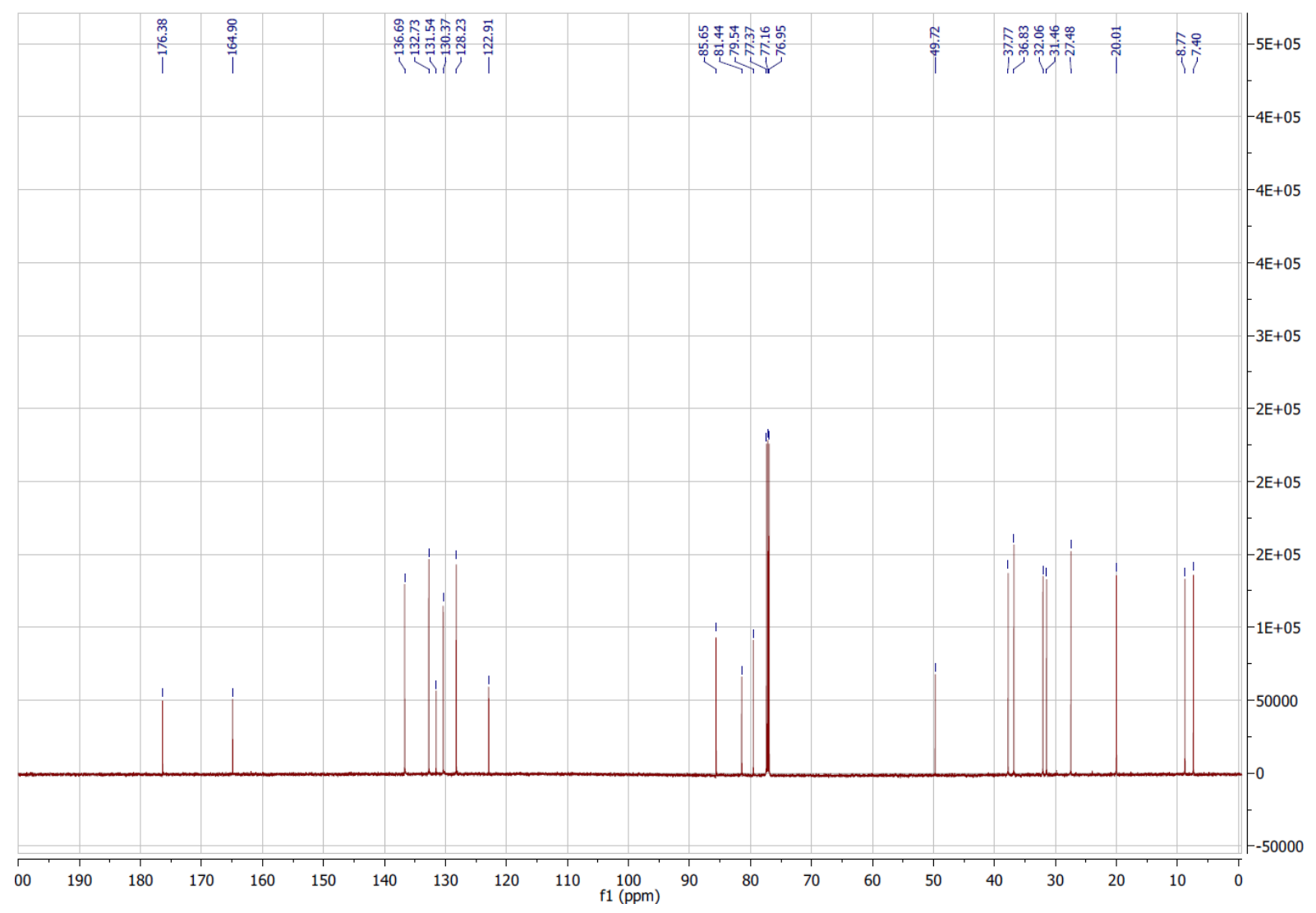


${ }^{1} \mathrm{H}$ NMR of 20u in $\mathrm{CDCl}_{3}(600 \mathrm{MHz})$

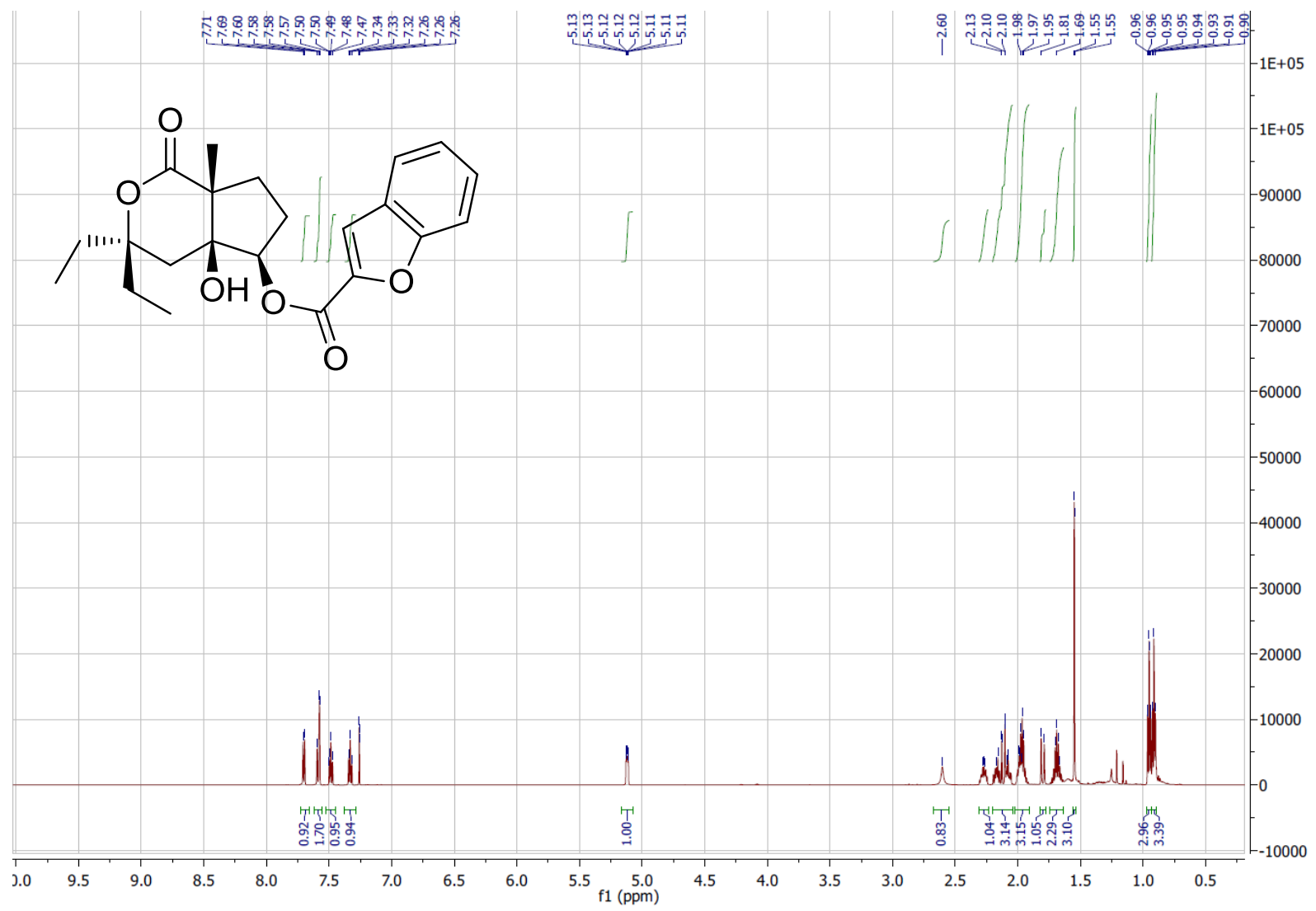

${ }^{13} \mathrm{C}$ NMR of $20 u$ in $\mathrm{CDCl}_{3}(151 \mathrm{MHz})$

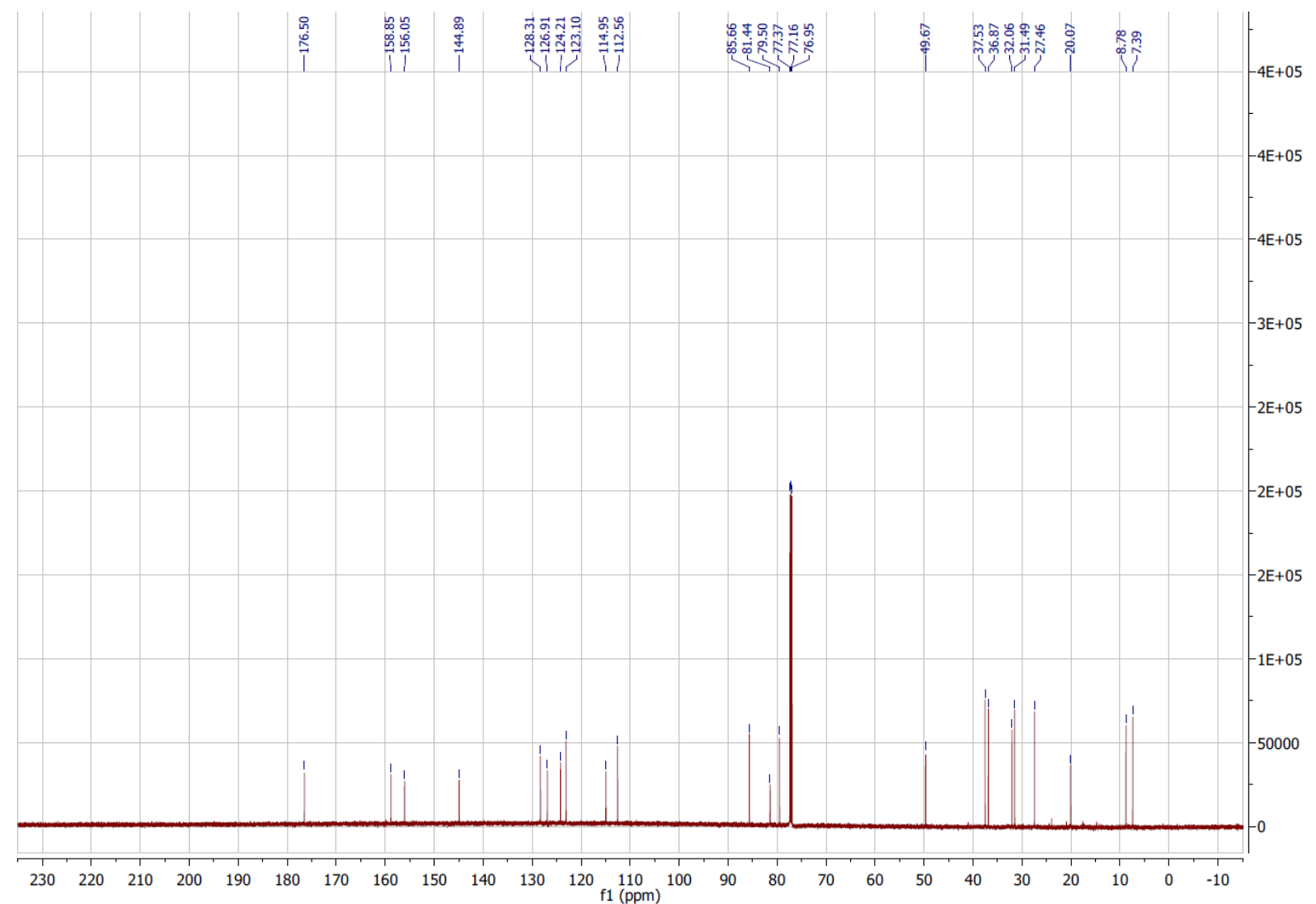


${ }^{1} \mathrm{H}$ NMR of $21 a$ in $\mathrm{CDCl}_{3}(600 \mathrm{MHz})$

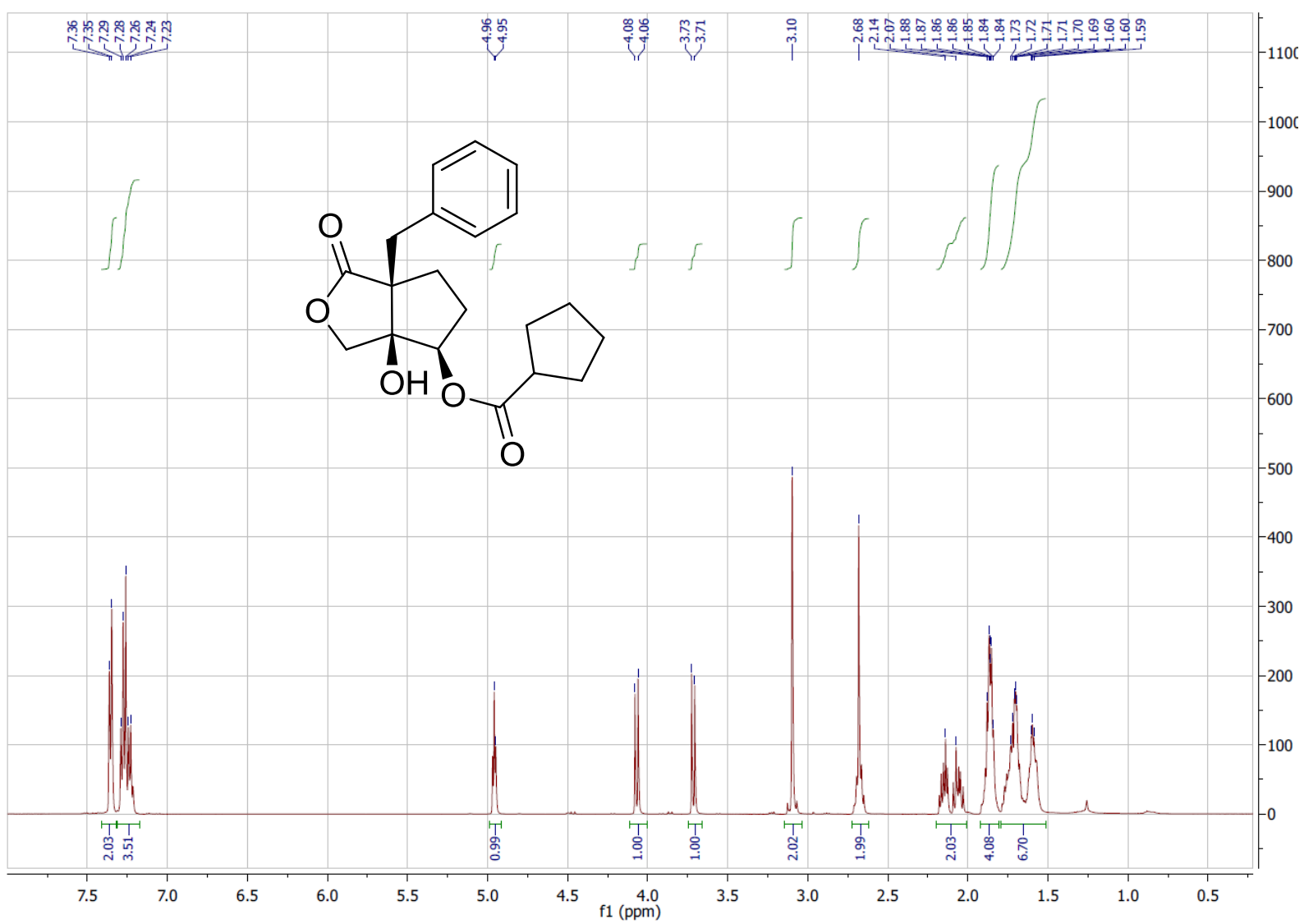

${ }^{13} \mathrm{C}$ NMR of 21a in $\mathrm{CDCl}_{3}(151 \mathrm{MHz})$

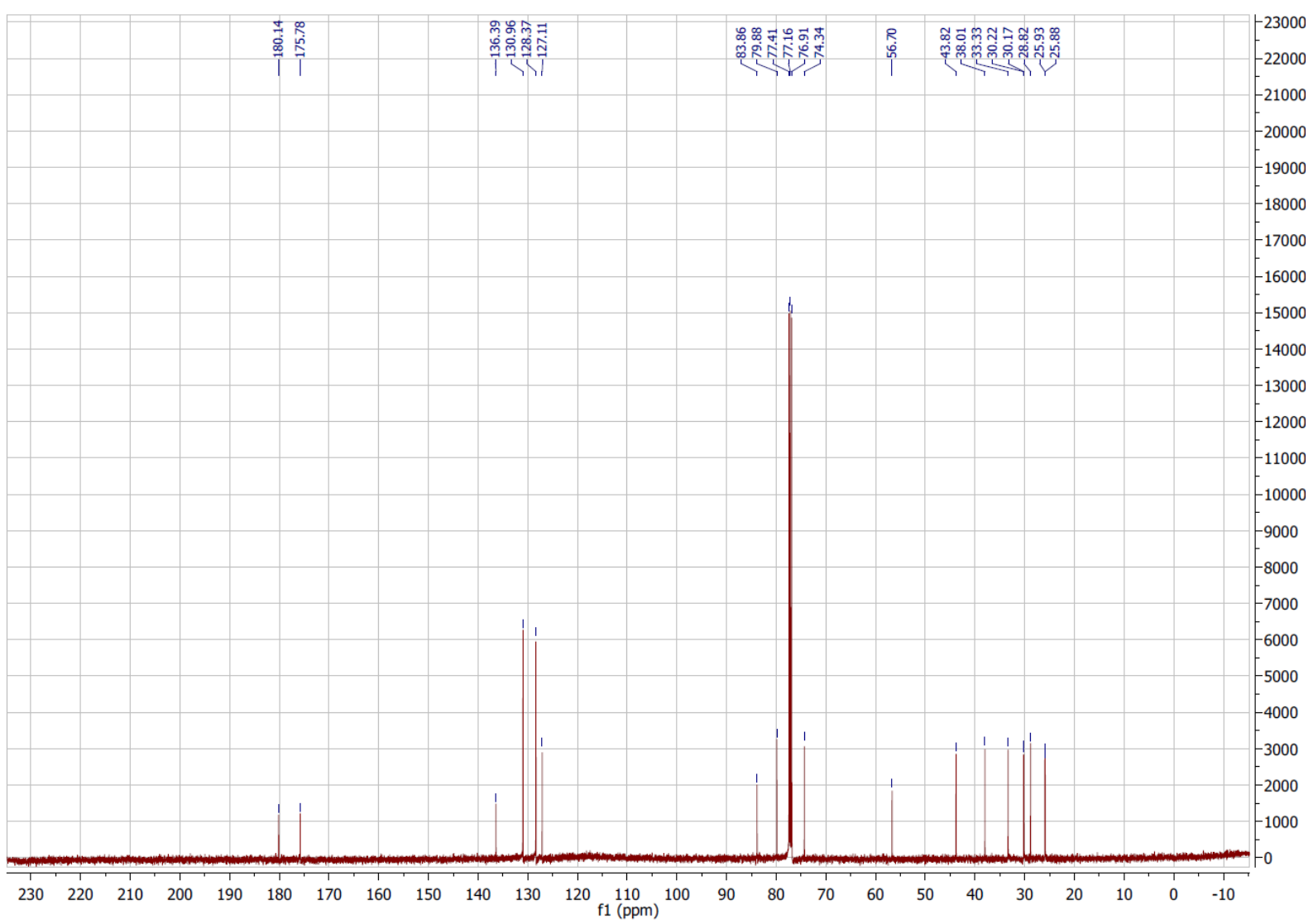


${ }^{1} \mathrm{H} \mathrm{NMR}$ of 21b in $\mathrm{CDCl}_{3}(400 \mathrm{MHz})$

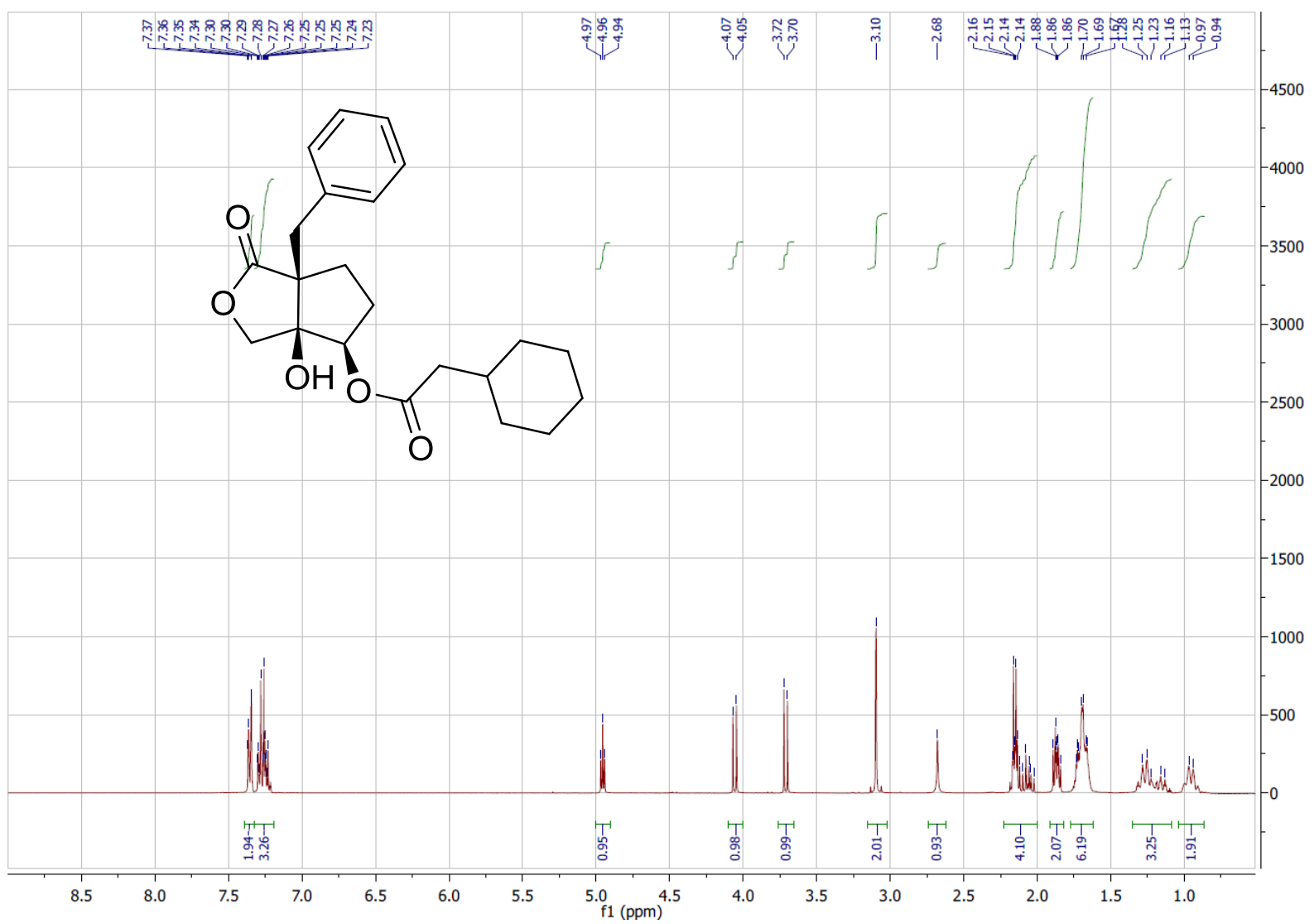

${ }^{13} \mathrm{C}$ NMR of $21 \mathbf{b}$ in $\mathrm{CDCl}_{3}(101 \mathrm{MHz})$

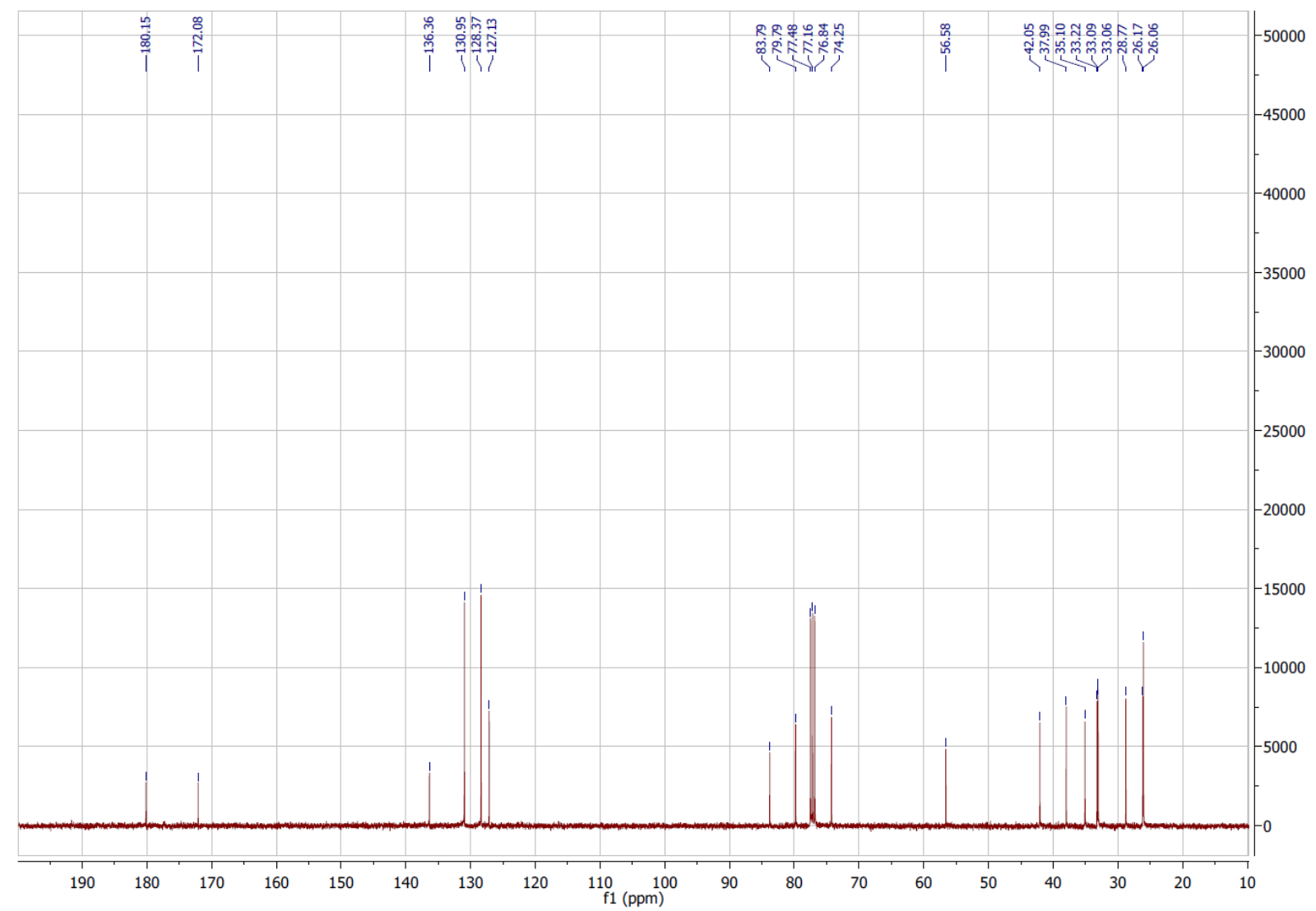


${ }^{1} \mathrm{H}$ NMR of 21c in $\mathrm{CDCl}_{3}(400 \mathrm{MHz})$

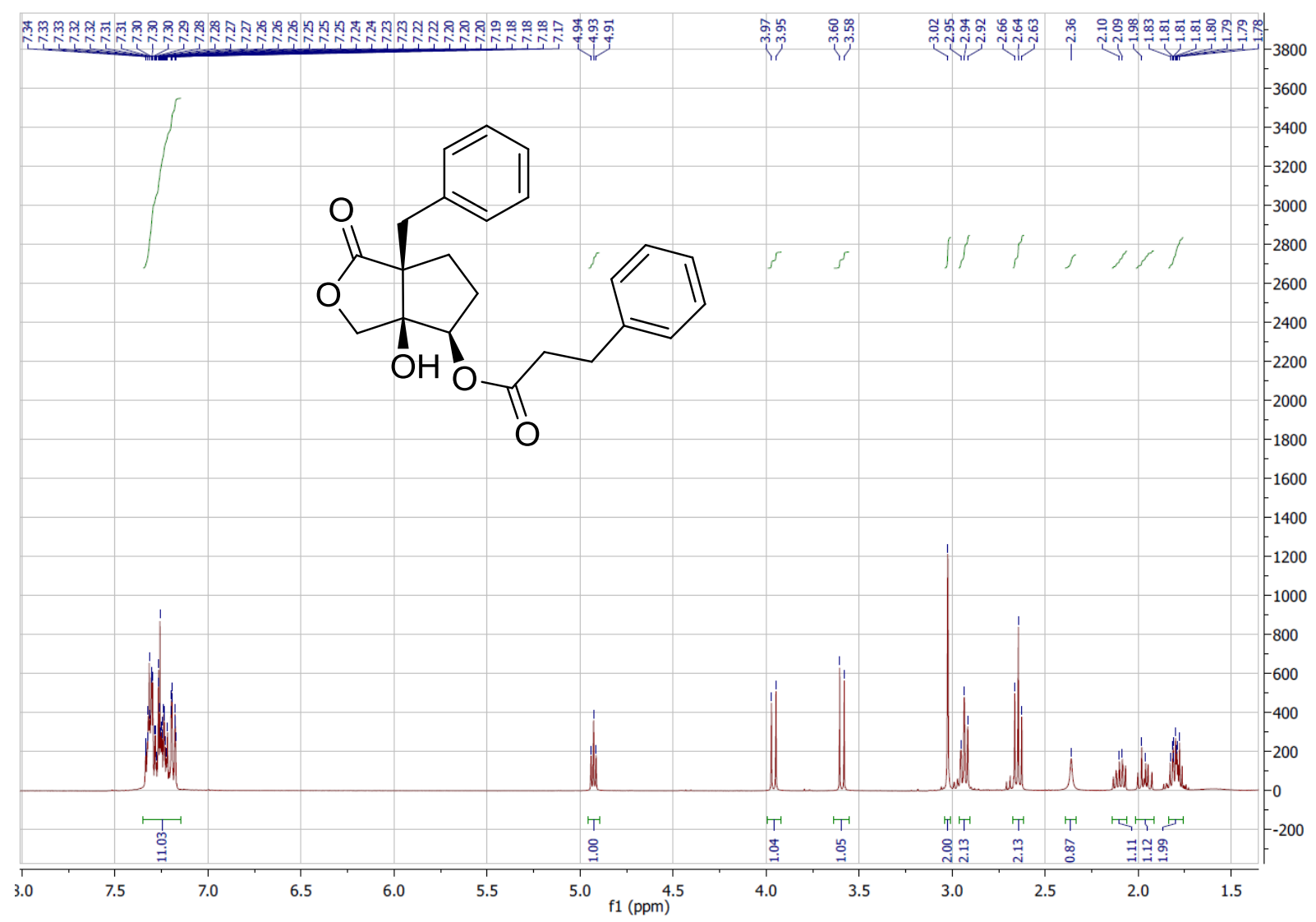

${ }^{13} \mathrm{C}$ NMR of 21c in $\mathrm{CDCl}_{3}(101 \mathrm{MHz})$

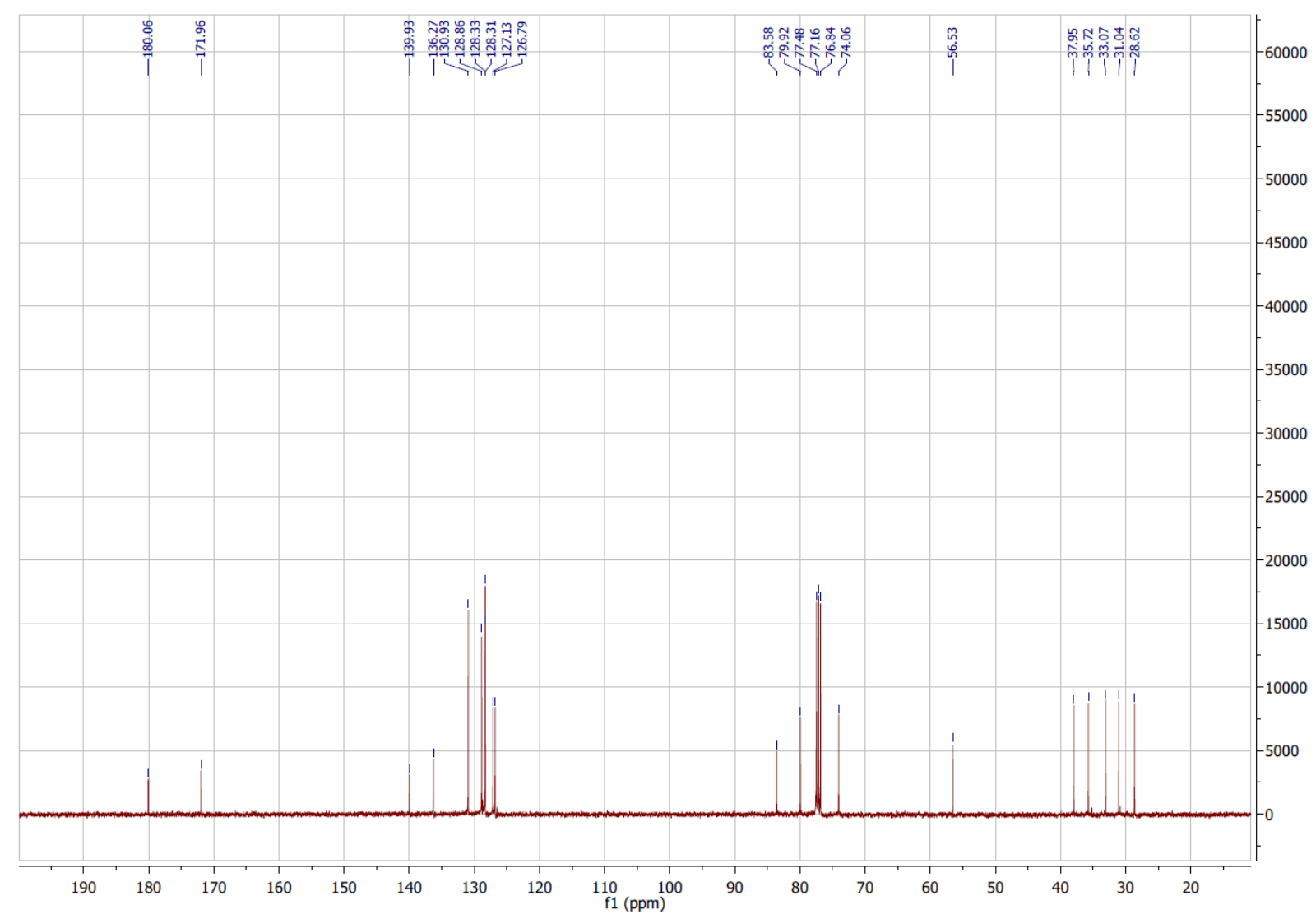


${ }^{1} \mathrm{H} \mathrm{NMR}$ of 21d in $\mathrm{CDCl}_{3}(400 \mathrm{MHz})$

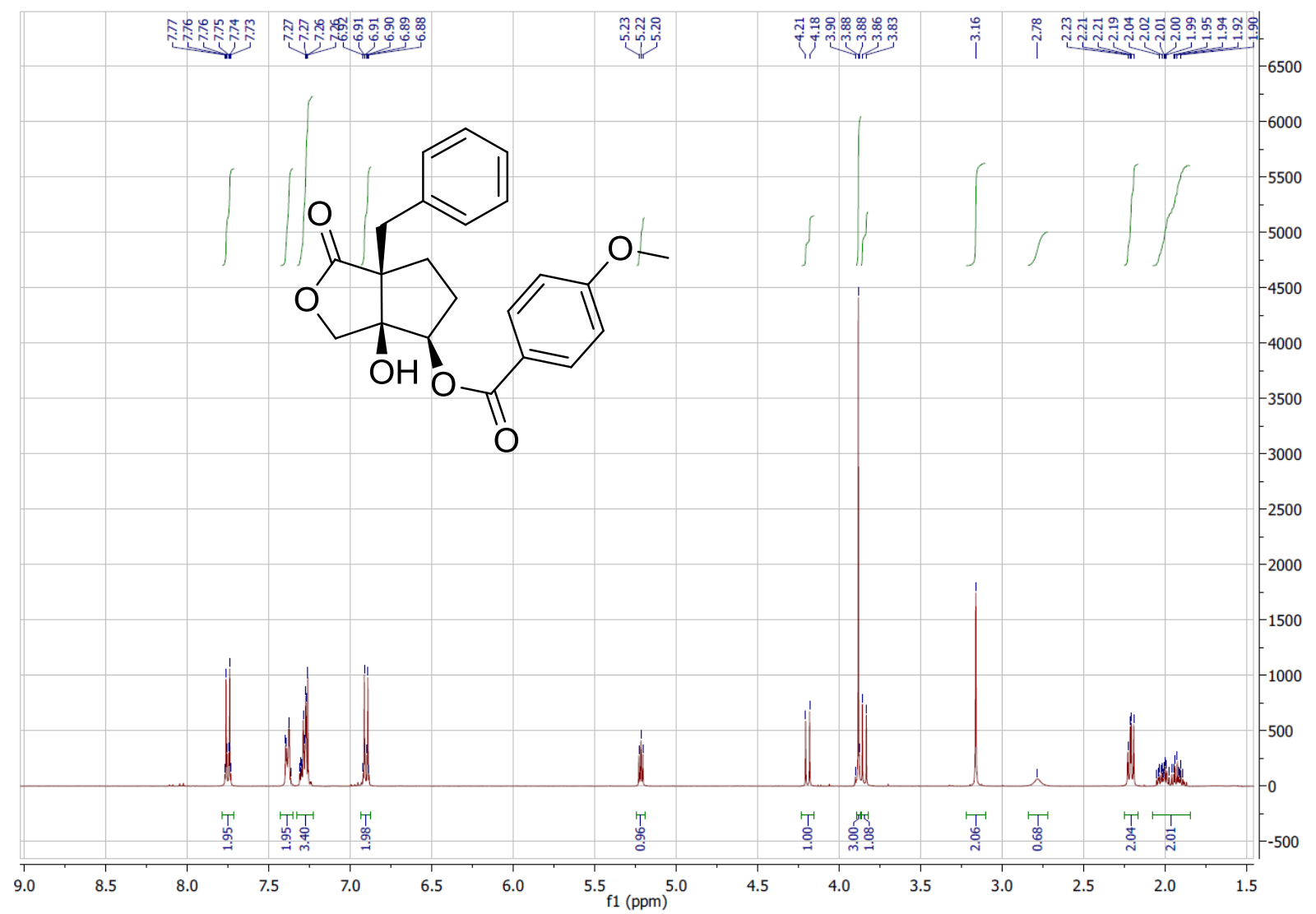

${ }^{13} \mathrm{C}$ NMR of 21d in $\mathrm{CDCl}_{3}(101 \mathrm{MHz})$

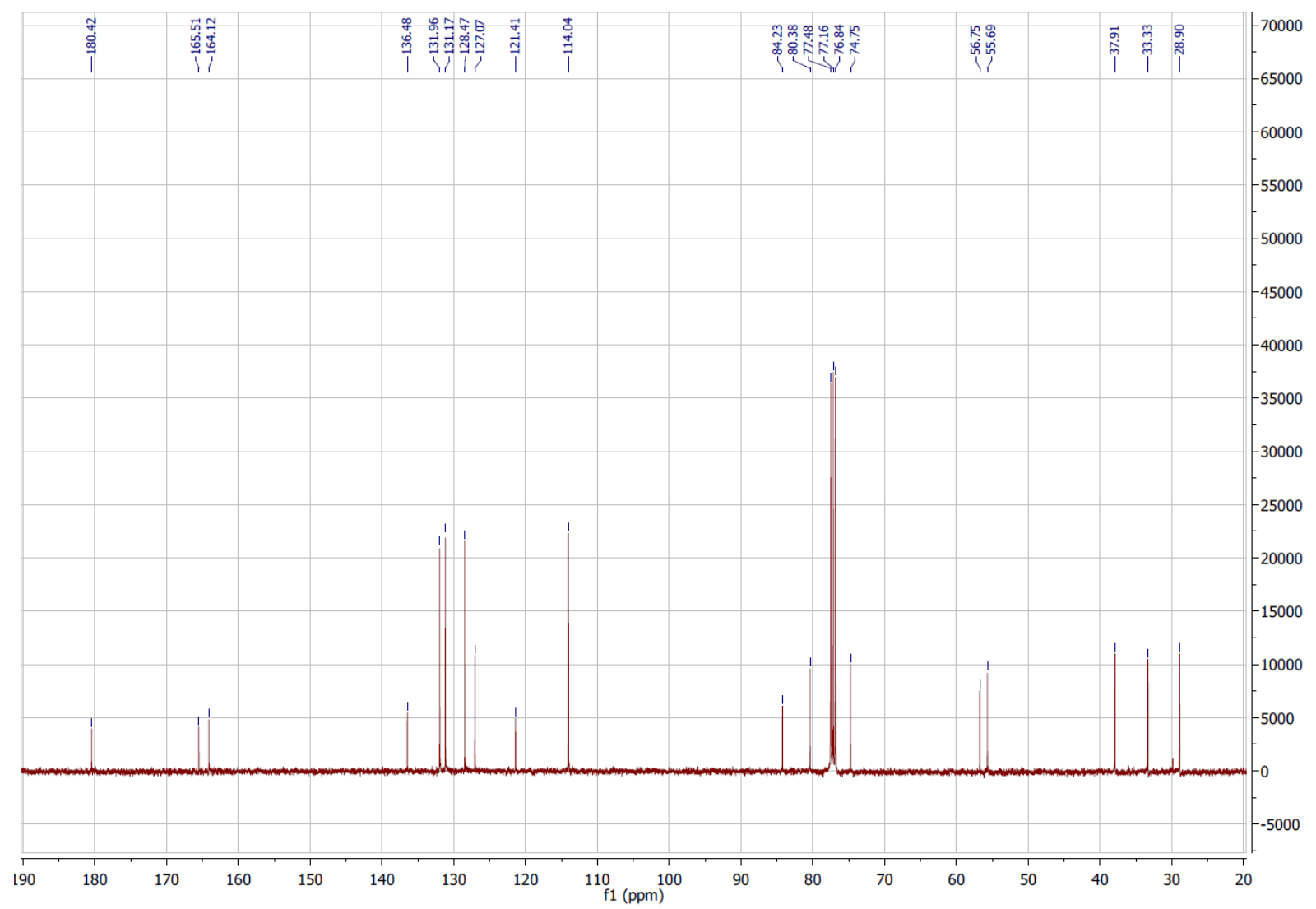


${ }^{1} \mathrm{H}$ NMR of 21e in $\mathrm{CDCl}_{3}(400 \mathrm{MHz})$

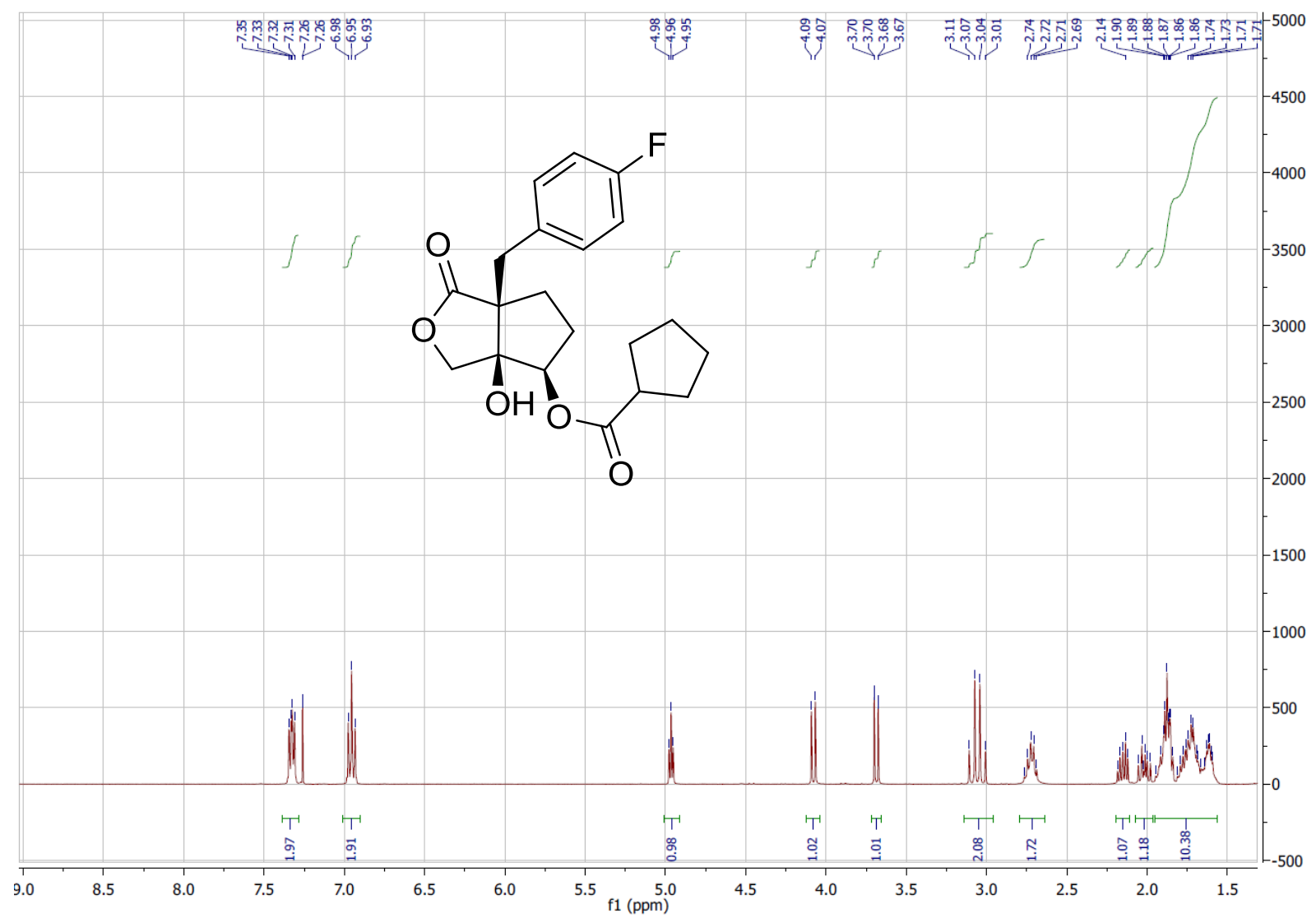

${ }^{13} \mathrm{C}$ NMR of 21e in $\mathrm{CDCl}_{3}(101 \mathrm{MHz})$

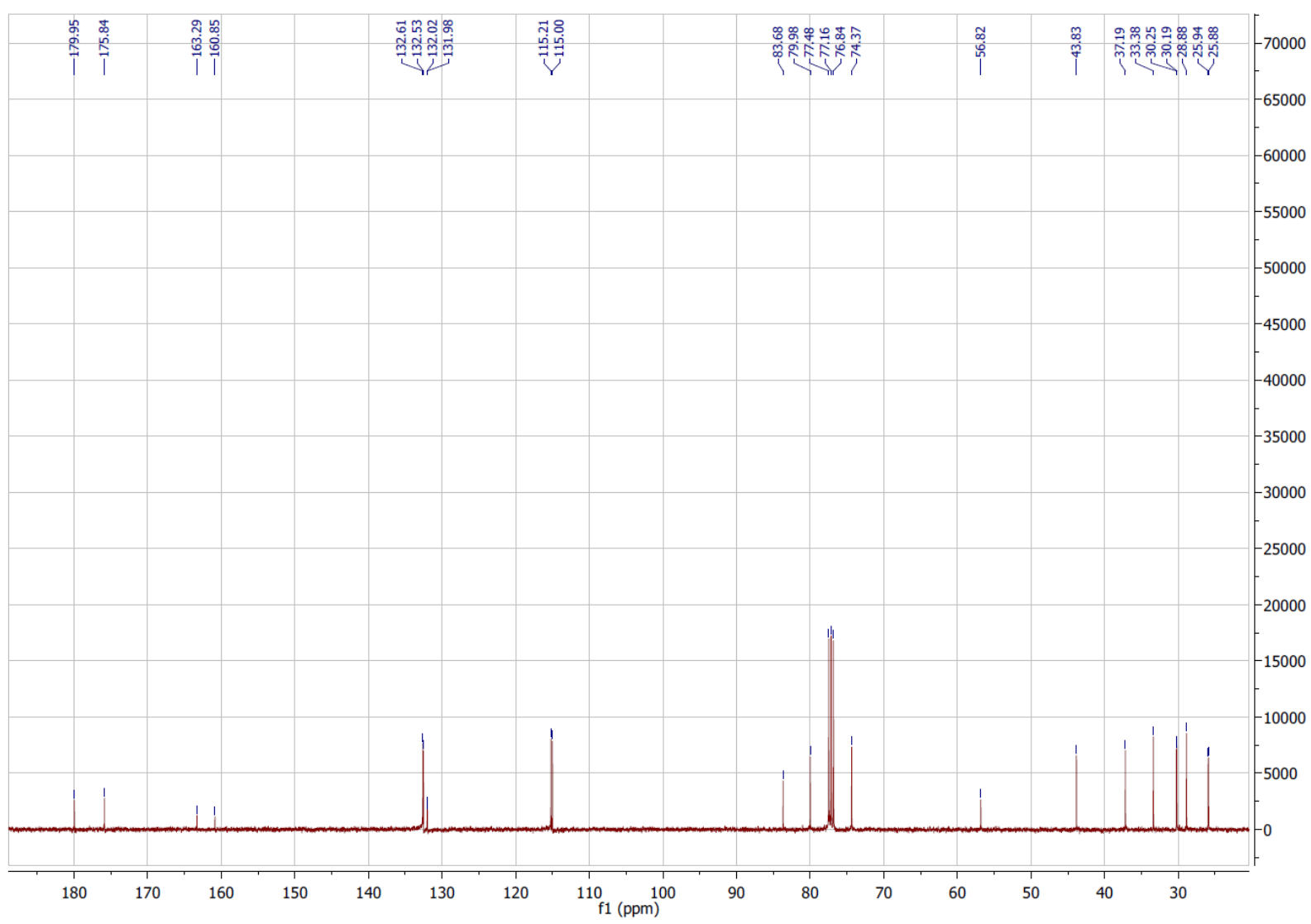


${ }^{1} \mathrm{H}$ NMR of $21 f$ in $\mathrm{CDCl}_{3}(600 \mathrm{MHz})$

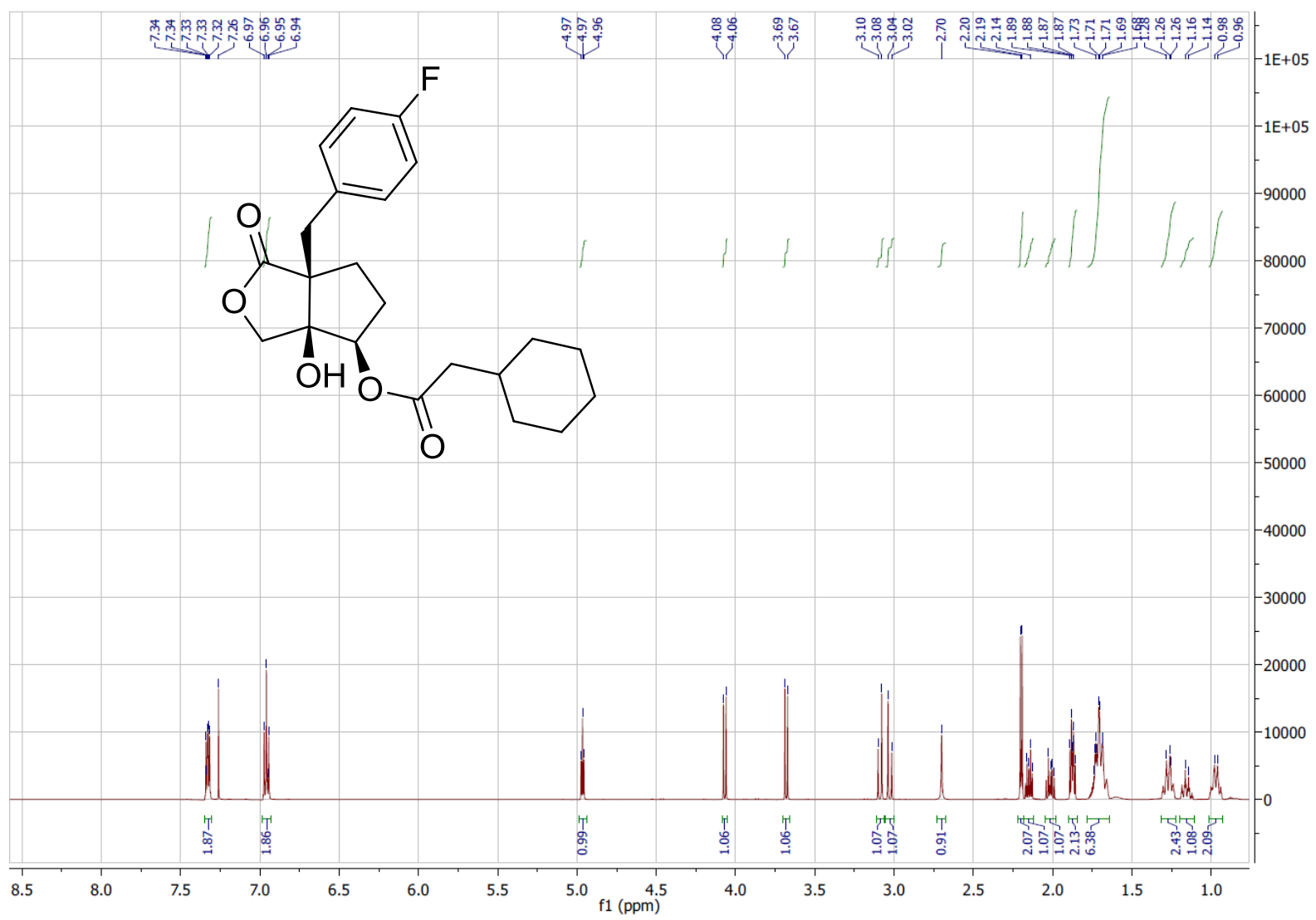

${ }^{13} \mathrm{C}$ NMR of $21 \mathrm{f}$ in $\mathrm{CDCl}_{3}(151 \mathrm{MHz})$

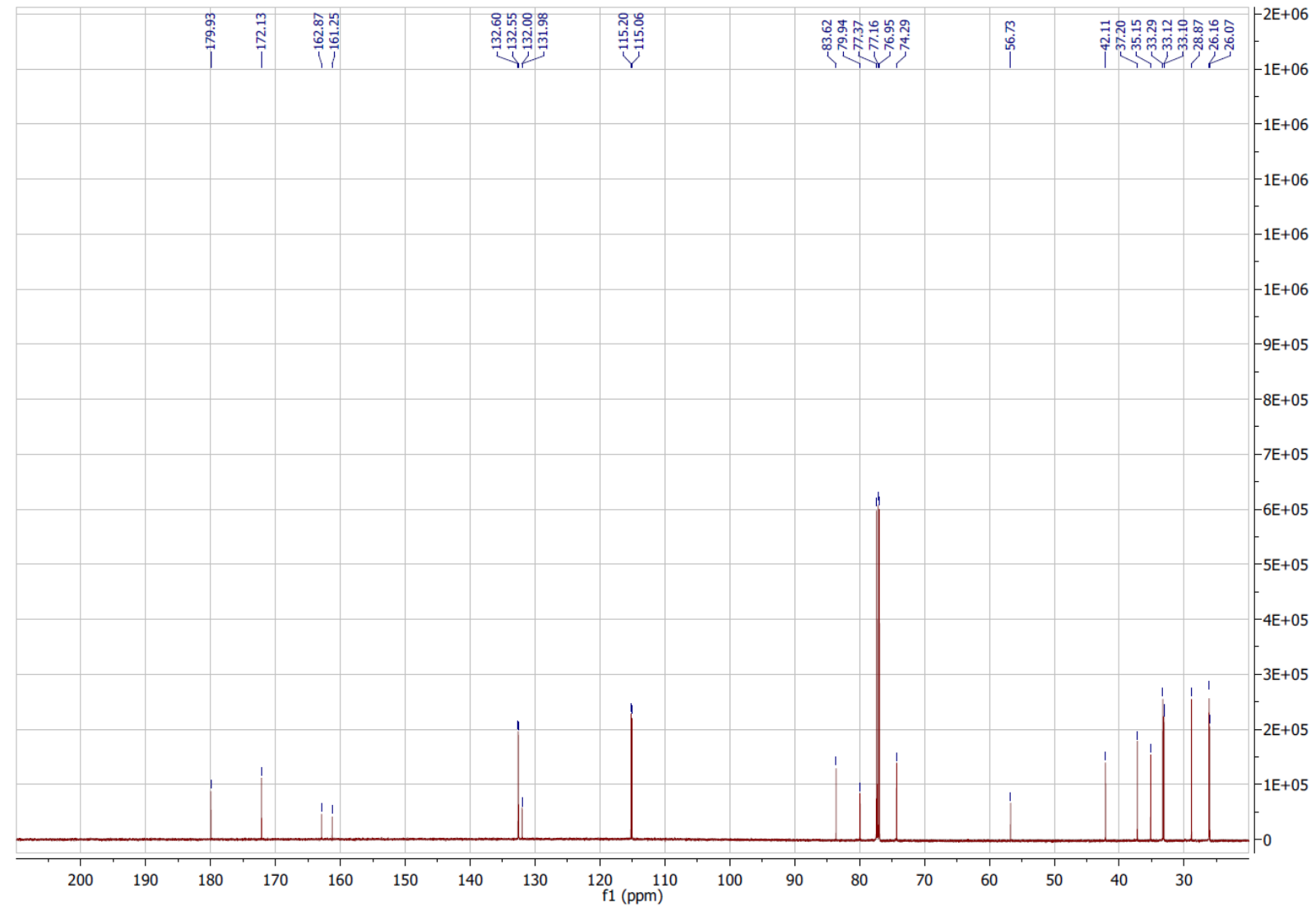


${ }^{1} \mathrm{H}$ NMR of $21 \mathrm{~g}$ in $\mathrm{CDCl}_{3}(600 \mathrm{MHz})$

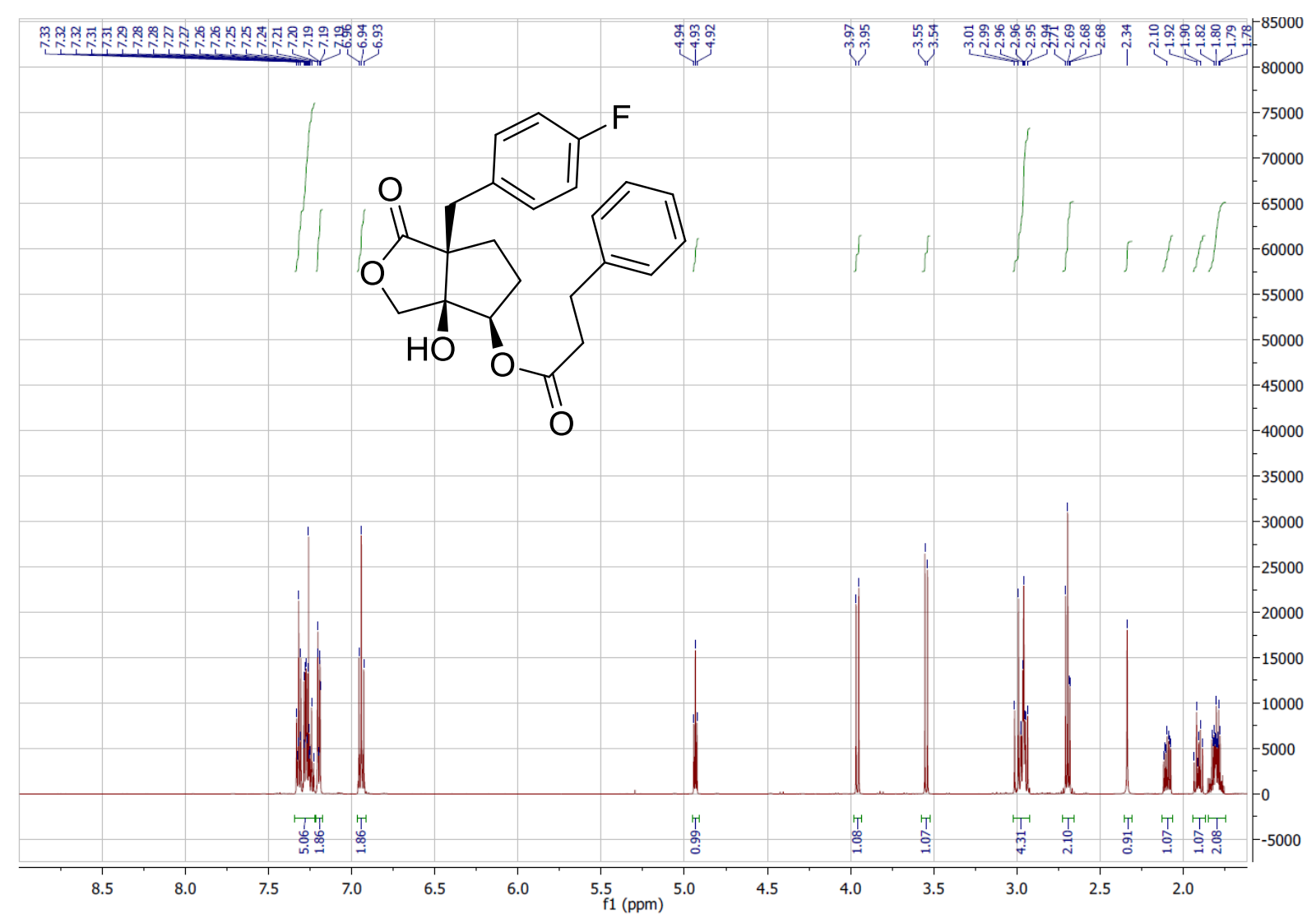

${ }^{13} \mathrm{C}$ NMR of $21 \mathrm{~g}$ in $\mathrm{CDCl}_{3}(151 \mathrm{MHz})$

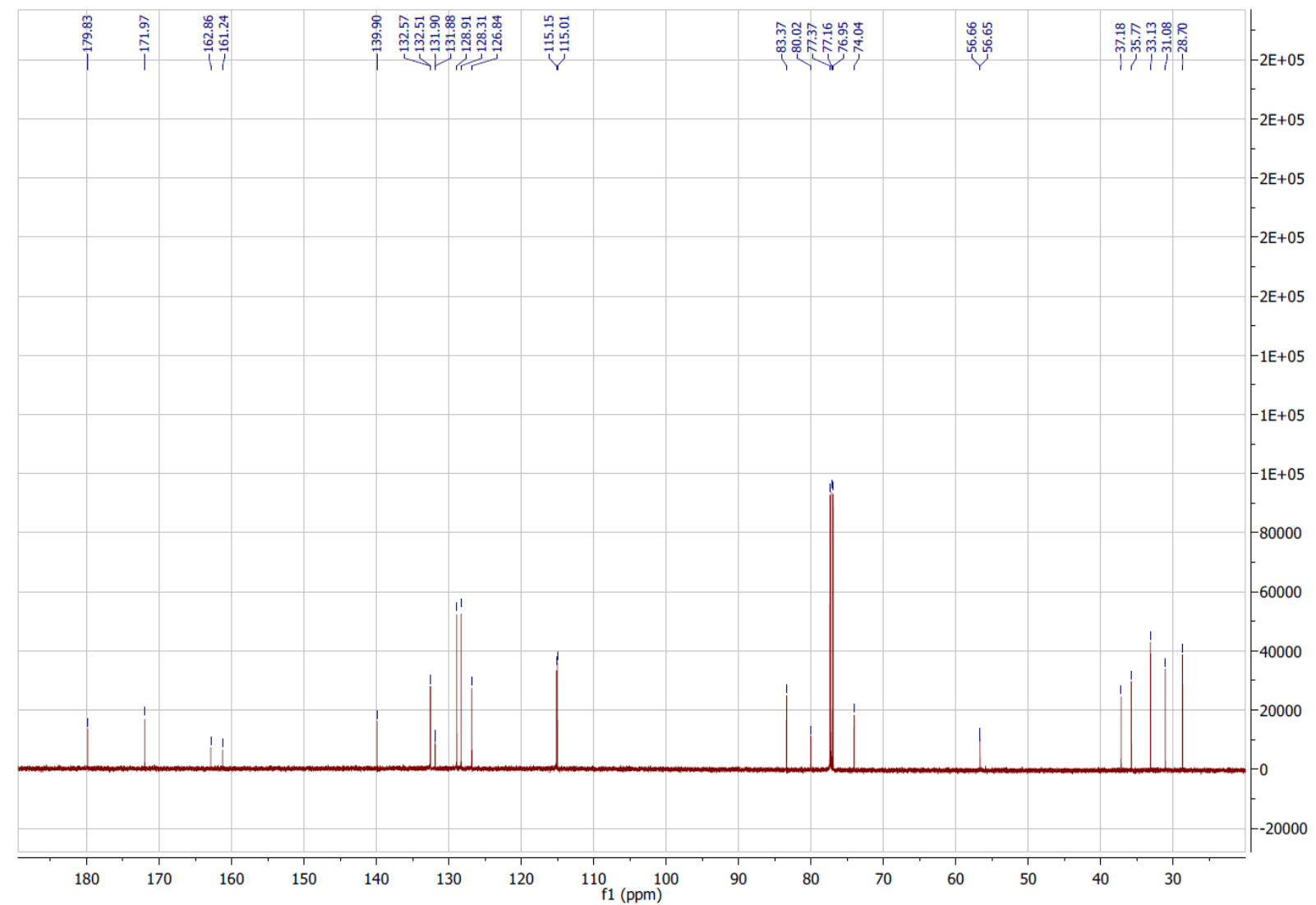


${ }^{1} \mathrm{H} \mathrm{NMR}$ of $\mathbf{2 1 h}$ in $\mathrm{CDCl}_{3}(600 \mathrm{MHz})$

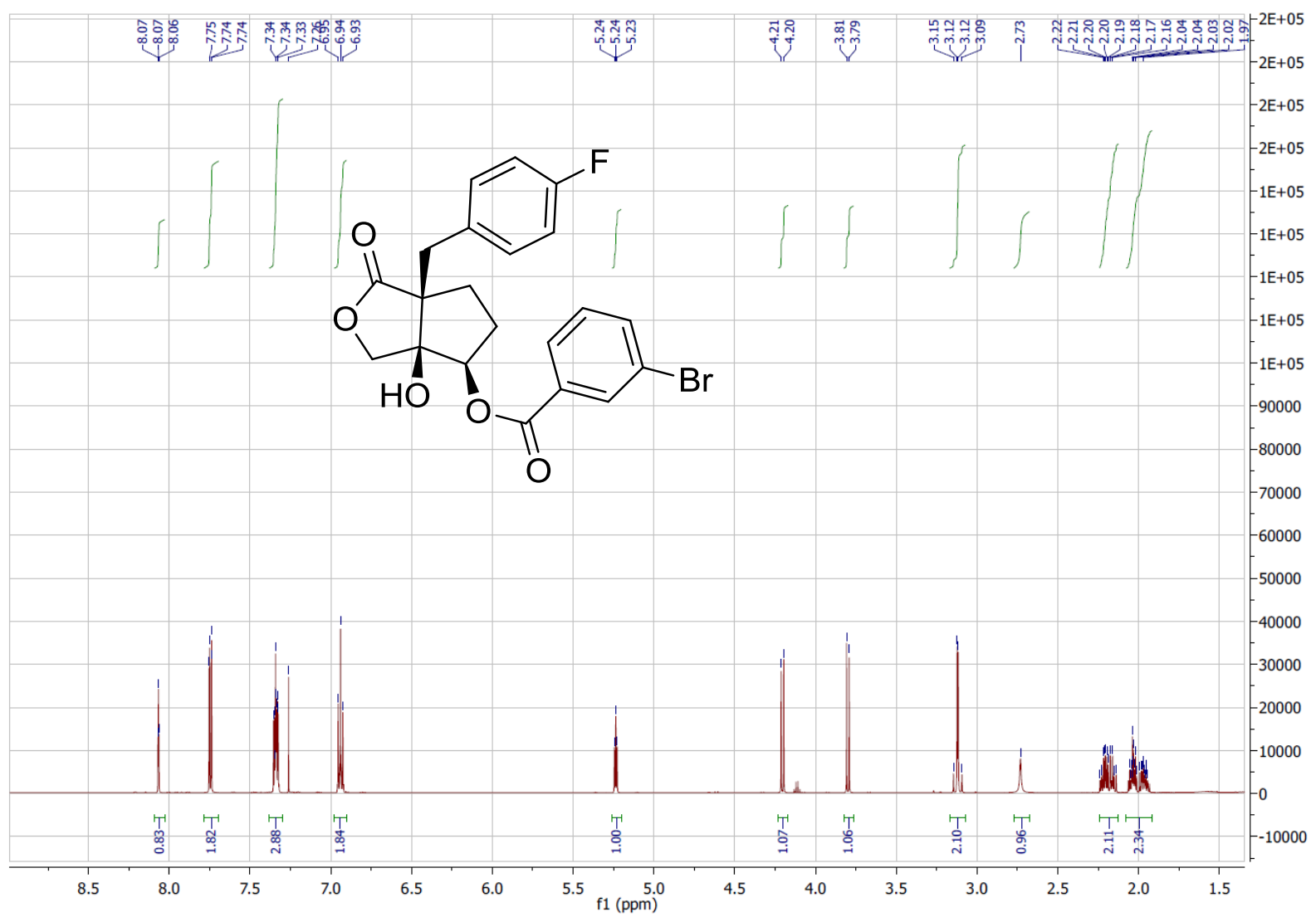

${ }^{13} \mathrm{C}$ NMR of $21 \mathbf{h}$ in $\mathrm{CDCl}_{3}(151 \mathrm{MHz})$

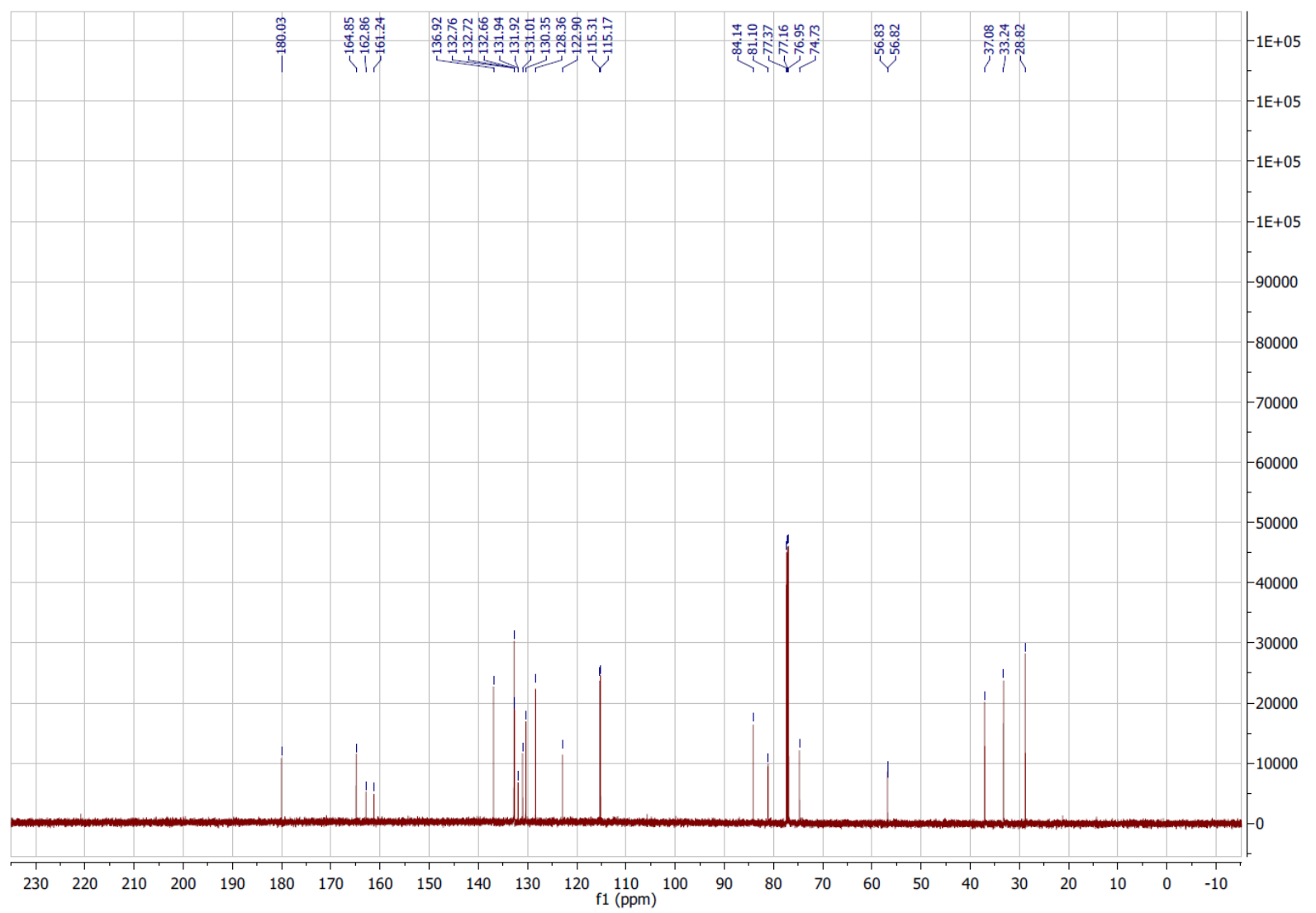


${ }^{1} \mathrm{H}$ NMR of $21 \mathbf{i}$ in $\mathrm{CDCl}_{3}(500 \mathrm{MHz})$

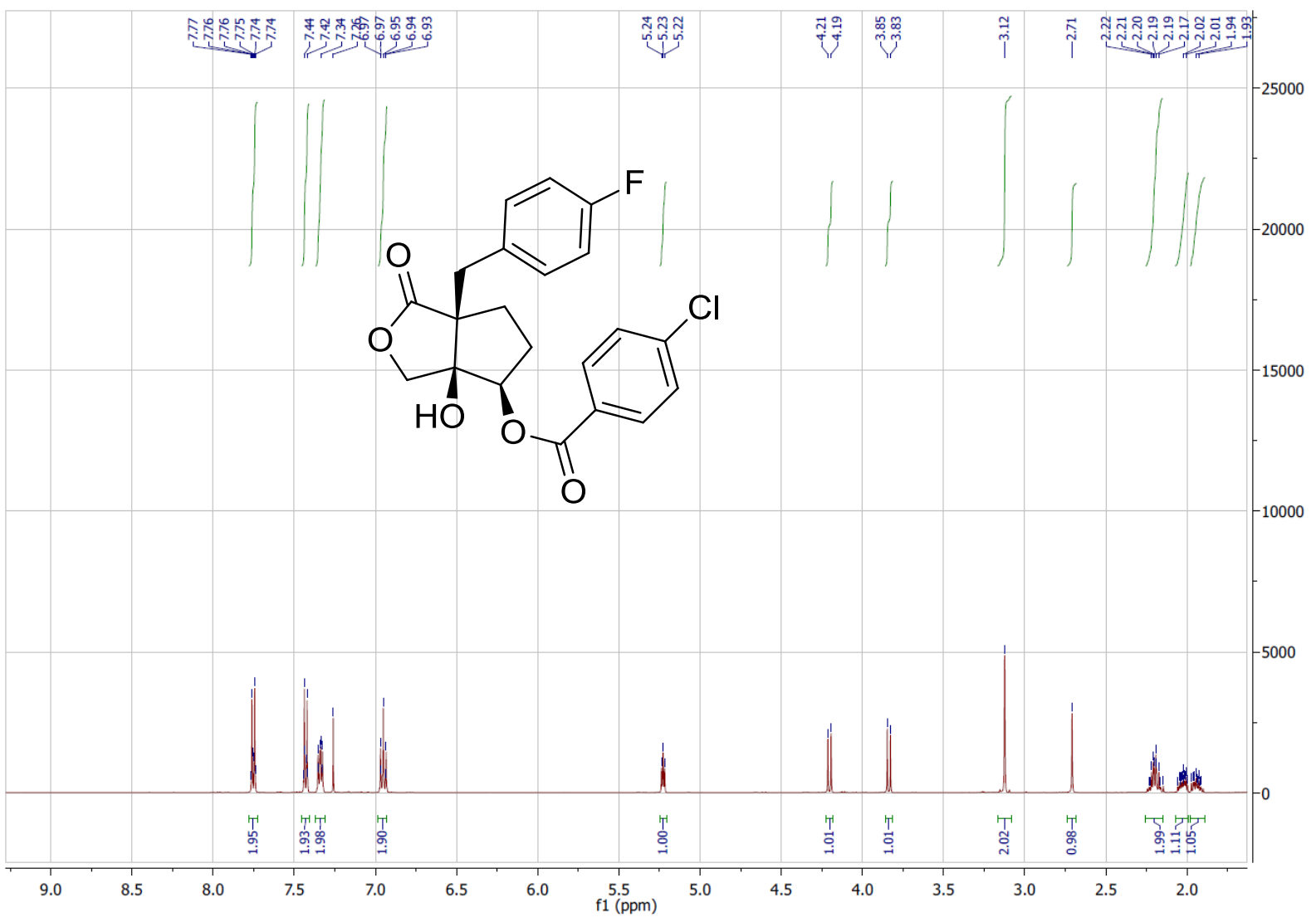

${ }^{13} \mathrm{C}$ NMR of $21 \mathrm{i}$ in $\mathrm{CDCl}_{3}(126 \mathrm{MHz})$

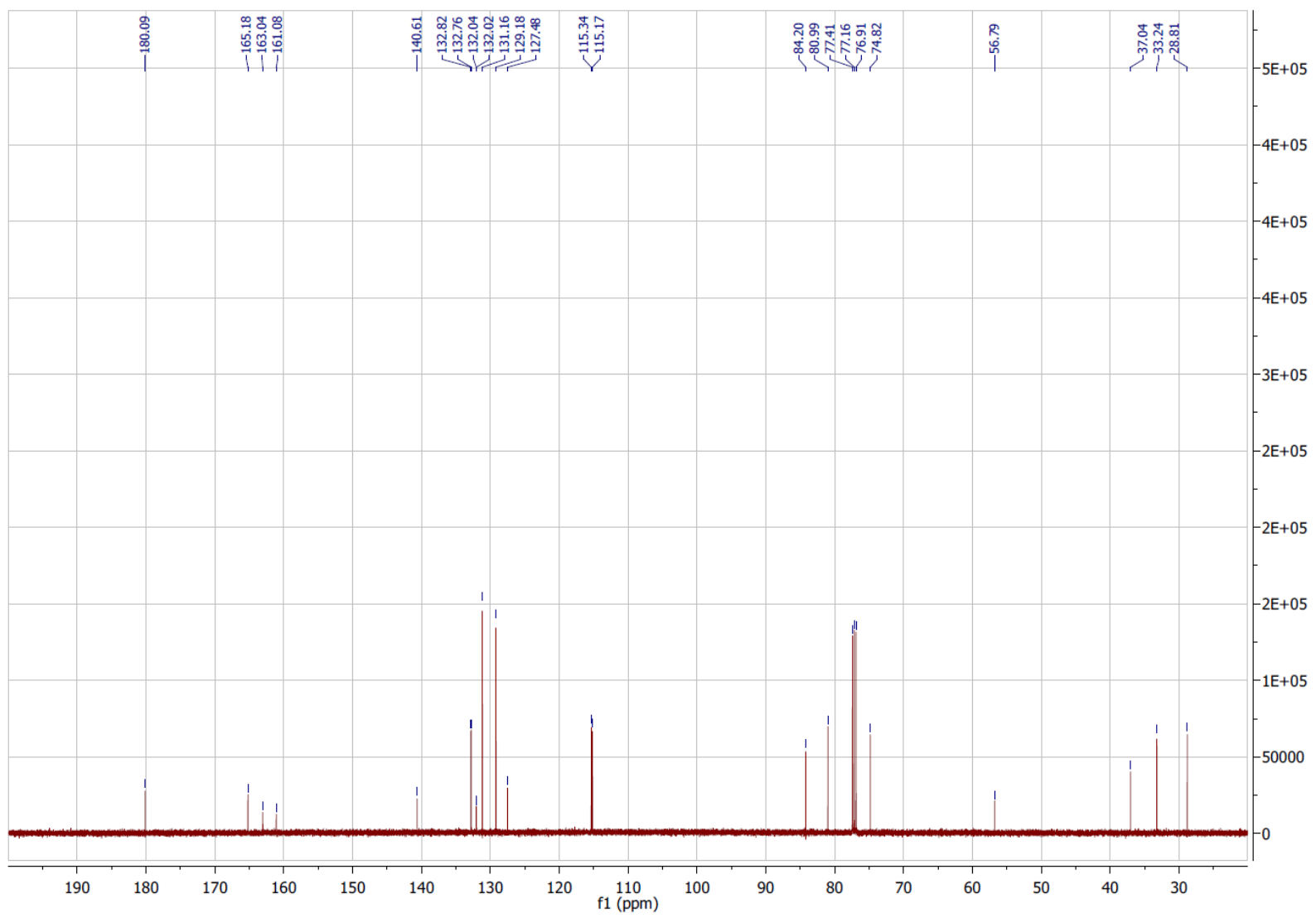


${ }^{1} \mathrm{H}$ NMR of $\mathbf{2 1} \mathbf{j}$ in $\mathrm{CDCl}_{3}(500 \mathrm{MHz})$

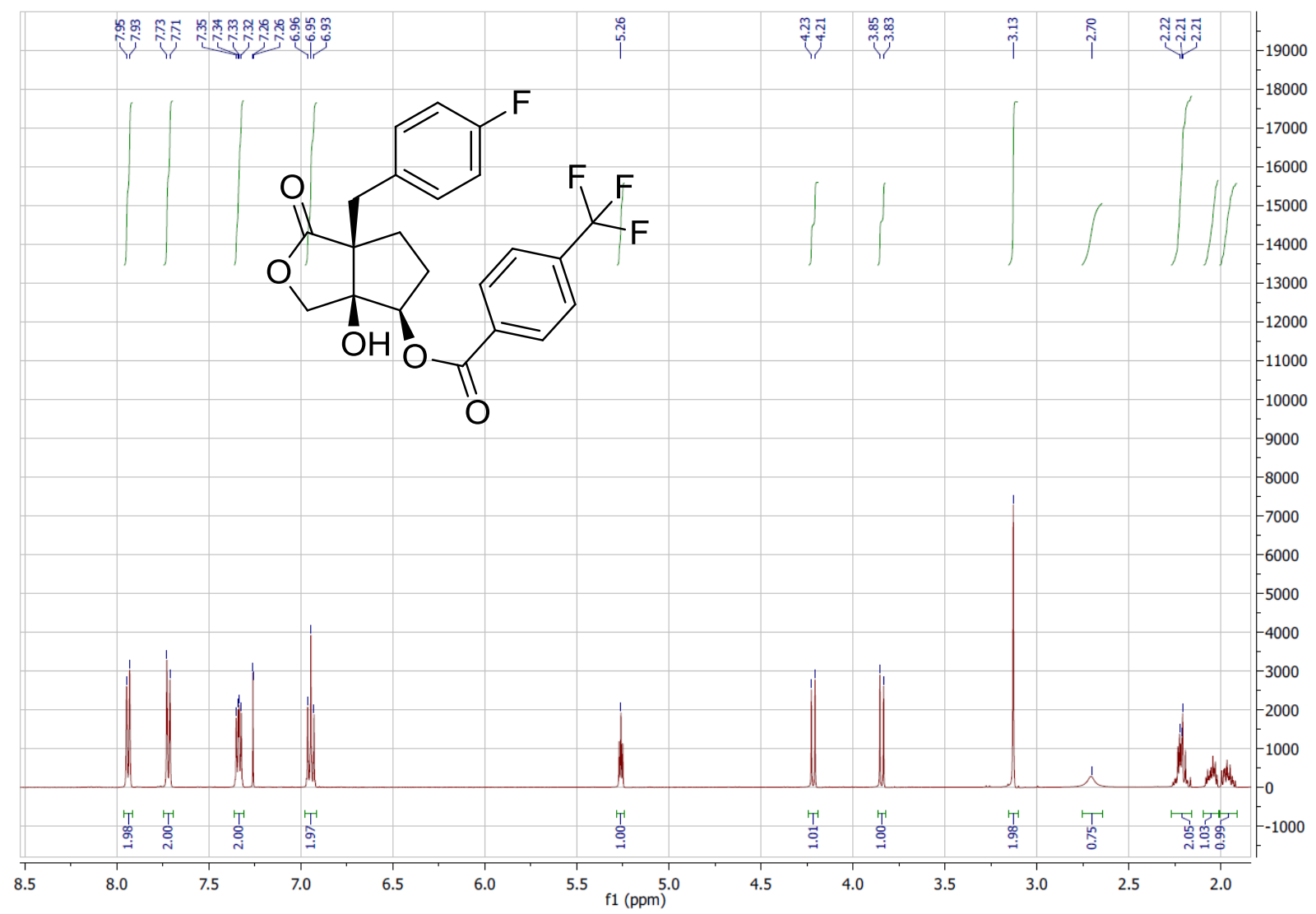

${ }^{13} \mathrm{C}$ NMR of $\mathbf{2 1} \mathbf{j}$ in $\mathrm{CDCl}_{3}(126 \mathrm{MHz})$

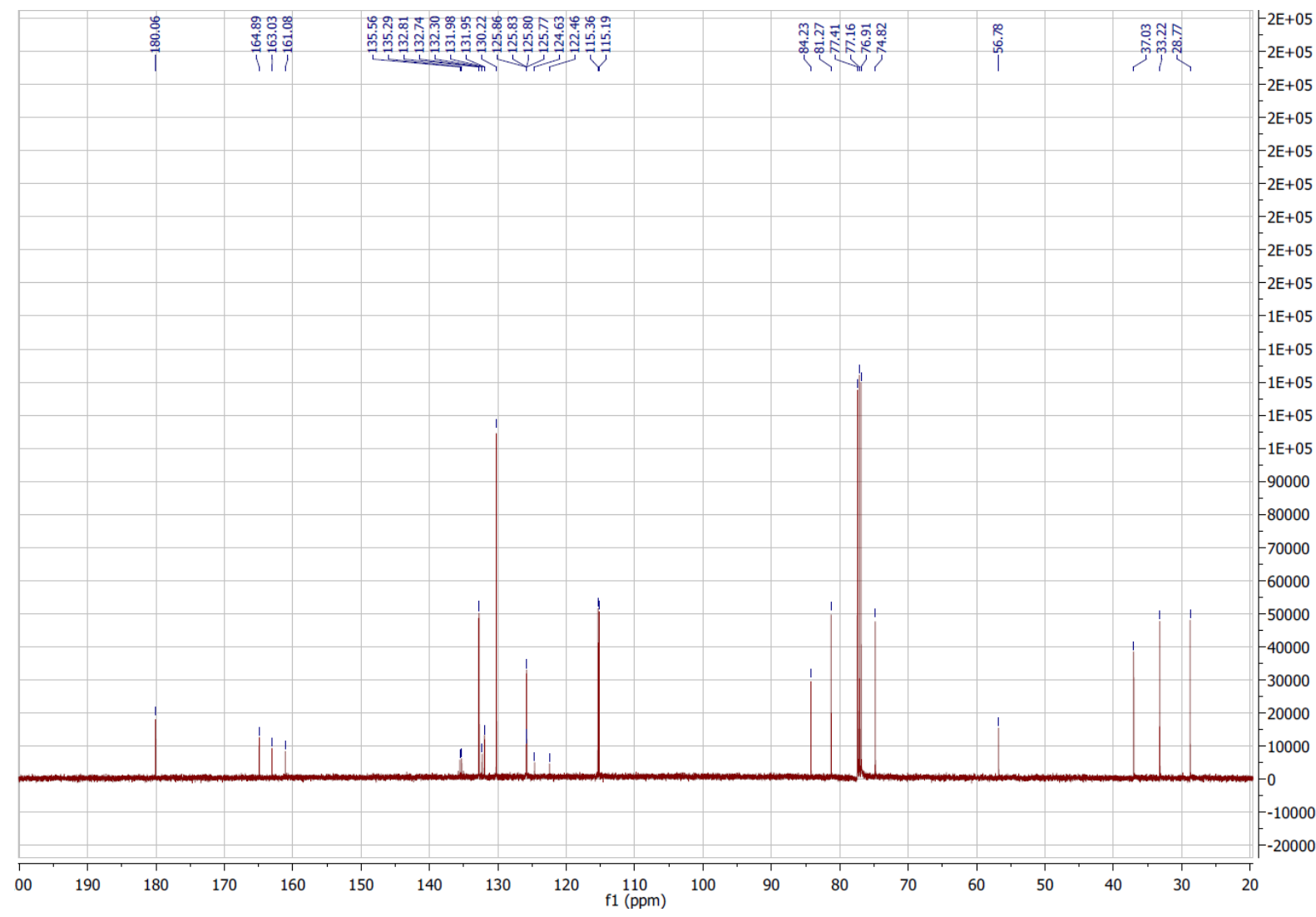


${ }^{1} \mathrm{H}$ NMR of 21k in $\mathrm{CDCl}_{3}(600 \mathrm{MHz})$

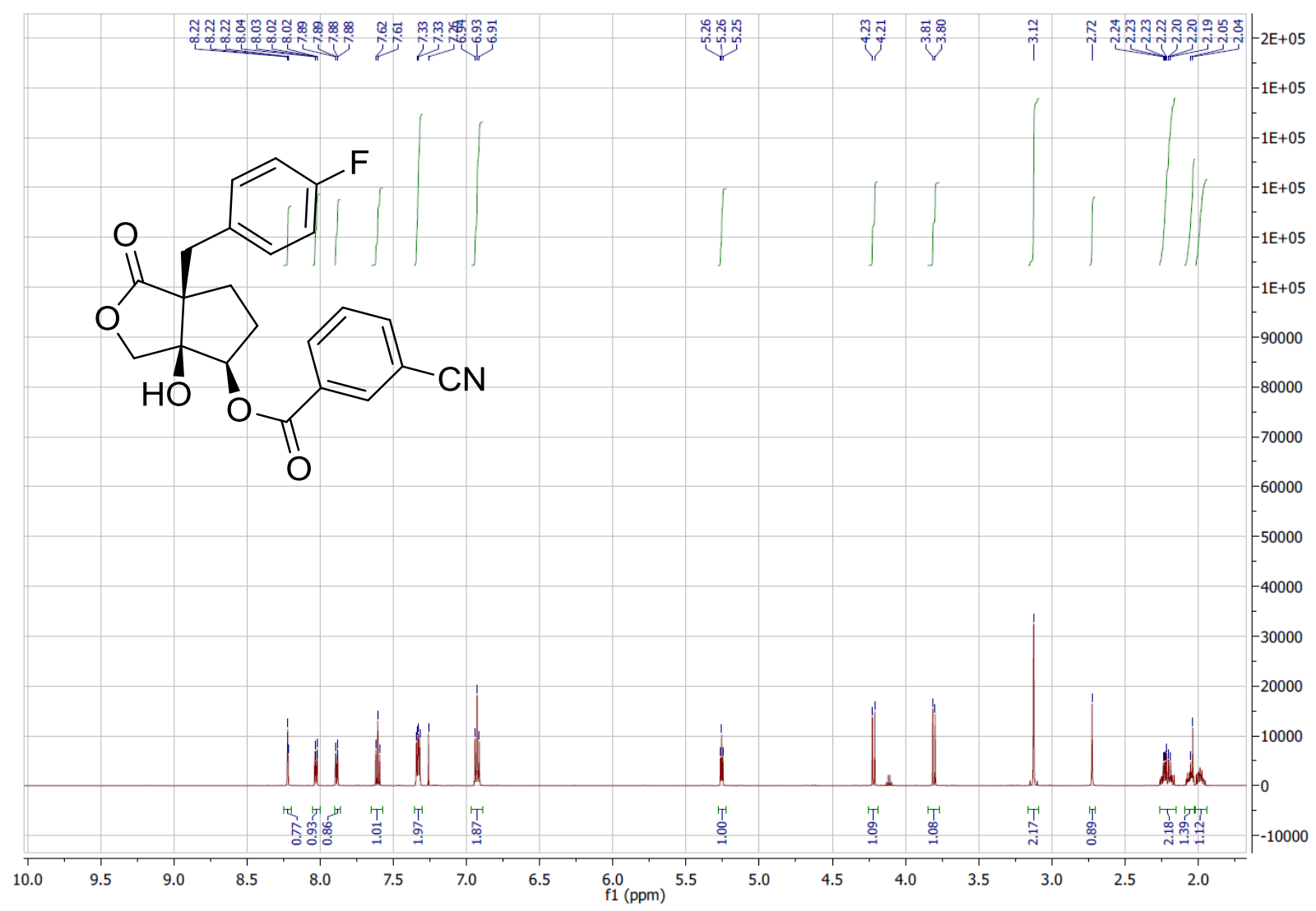

${ }^{13} \mathrm{C}$ NMR of $21 \mathbf{k}$ in $\mathrm{CDCl}_{3}(151 \mathrm{MHz})$

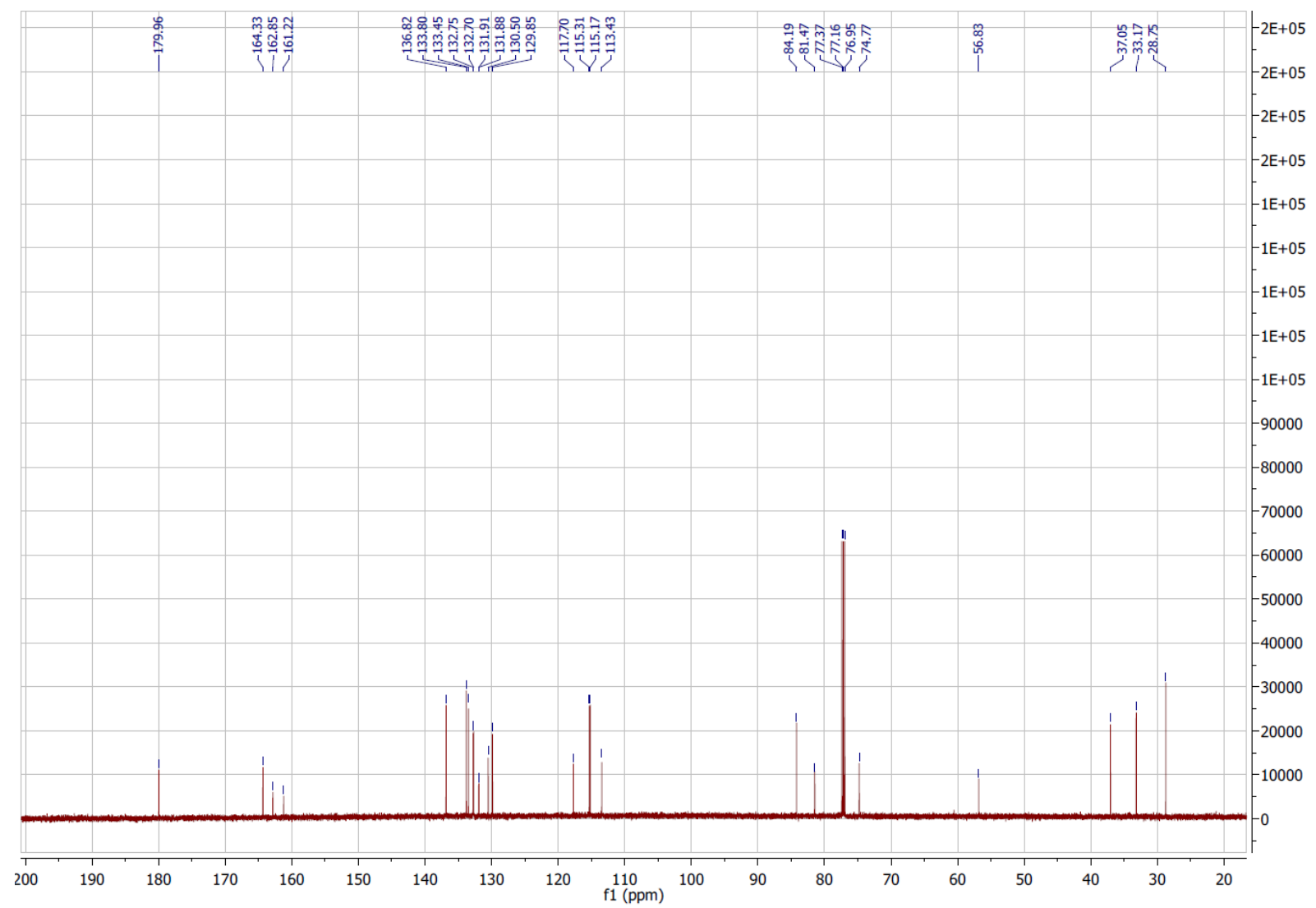


${ }^{1} \mathrm{H}$ NMR of 211 in $\mathrm{CDCl}_{3}(400 \mathrm{MHz})$

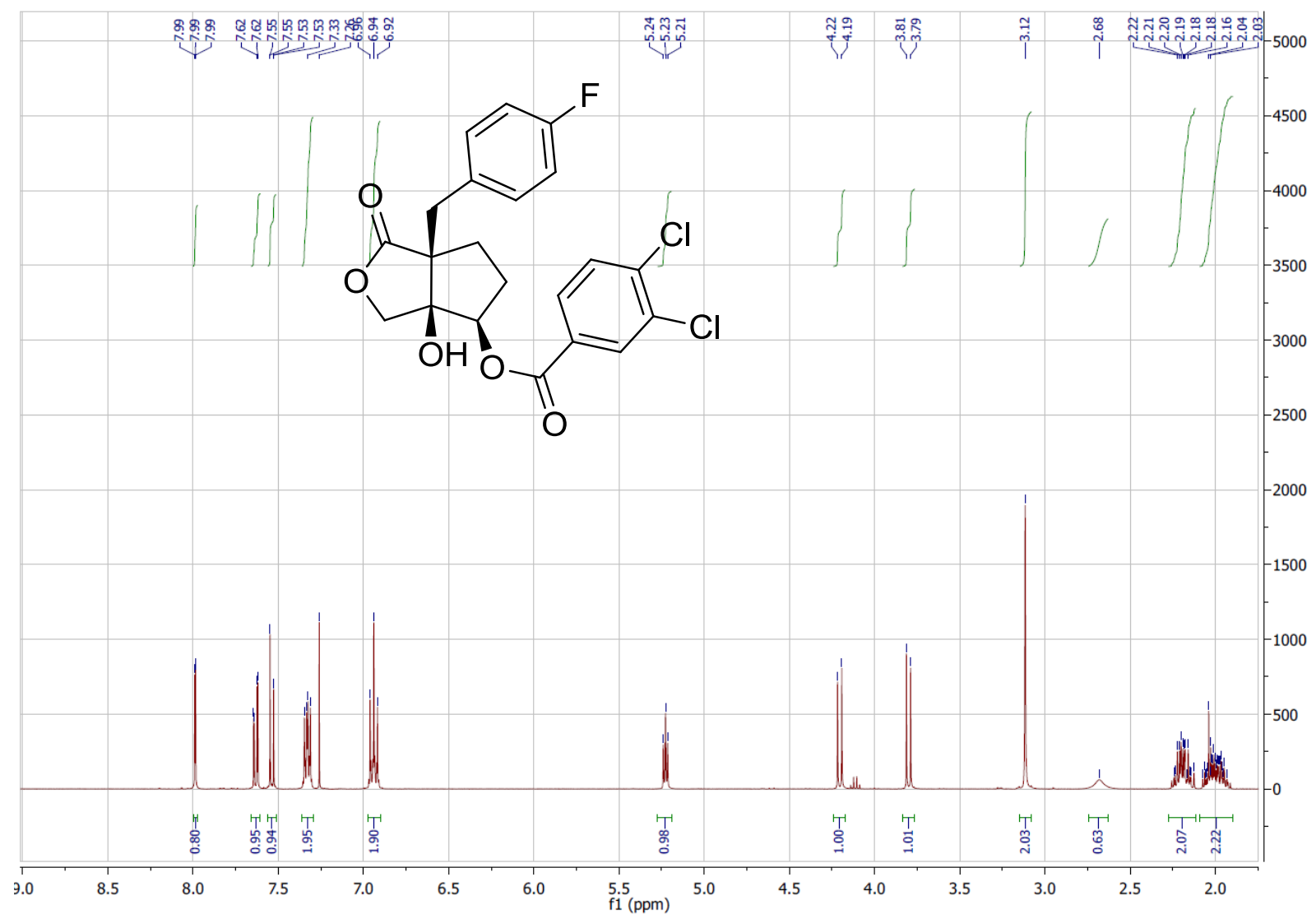

${ }^{13} \mathrm{C}$ NMR of 211 in $\mathrm{CDCl}_{3}(101 \mathrm{MHz})$

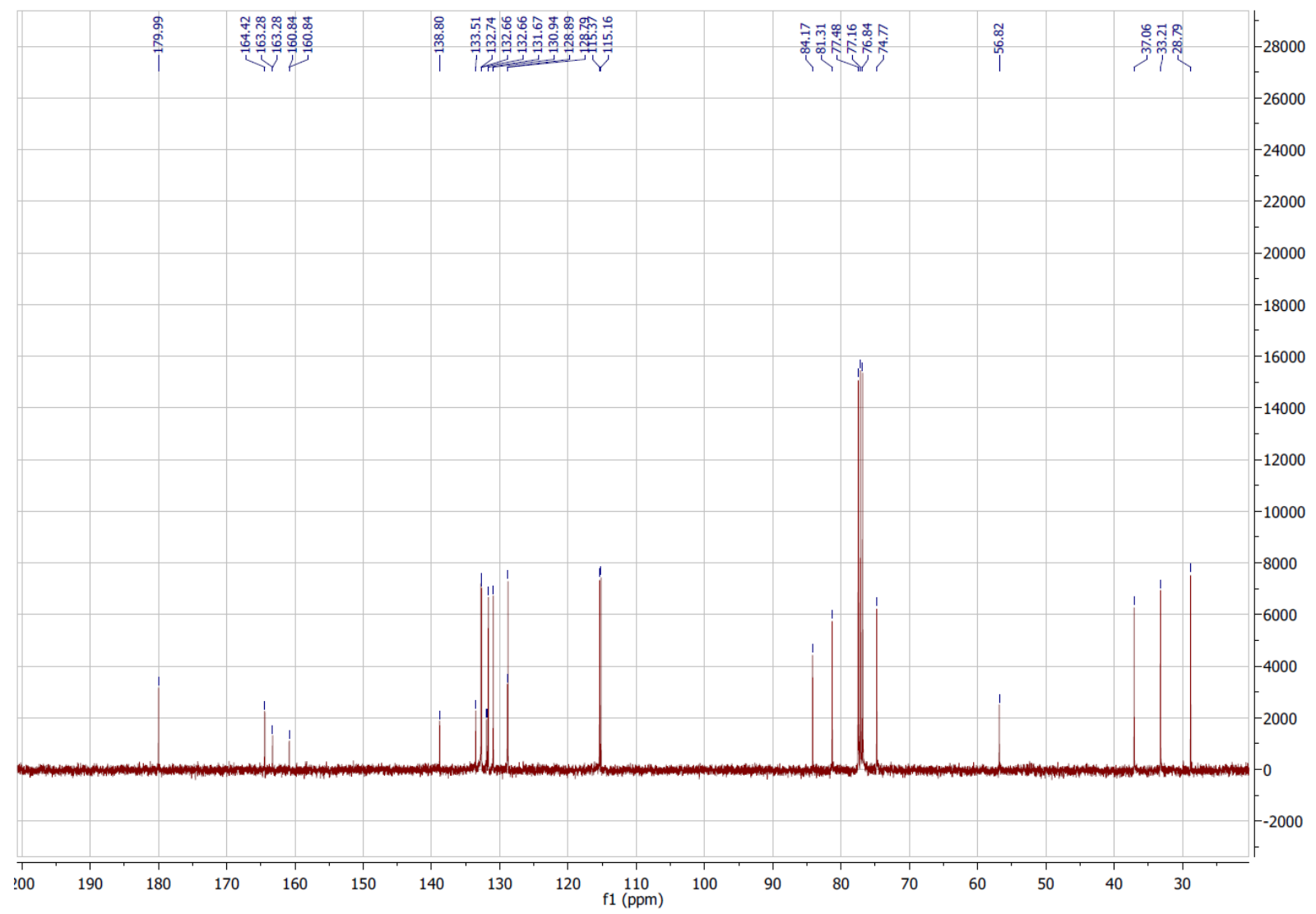


${ }^{1} \mathrm{H} \mathrm{NMR}$ of $\mathbf{2 1 m}$ in $\mathrm{CDCl}_{3}(600 \mathrm{MHz})$

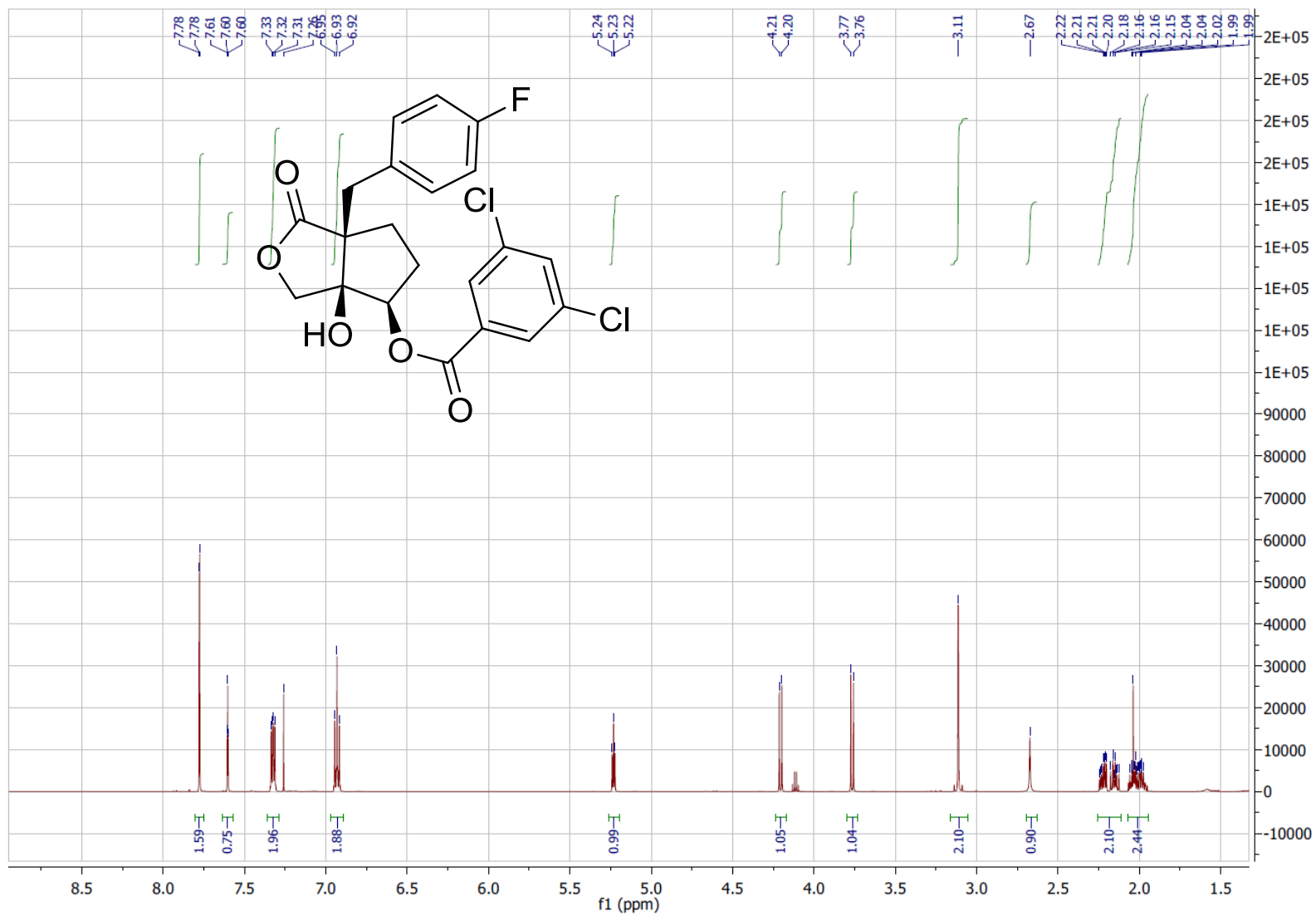

${ }^{13} \mathrm{C}$ NMR of $21 \mathrm{~m}$ in $\mathrm{CDCl}_{3}(151 \mathrm{MHz})$

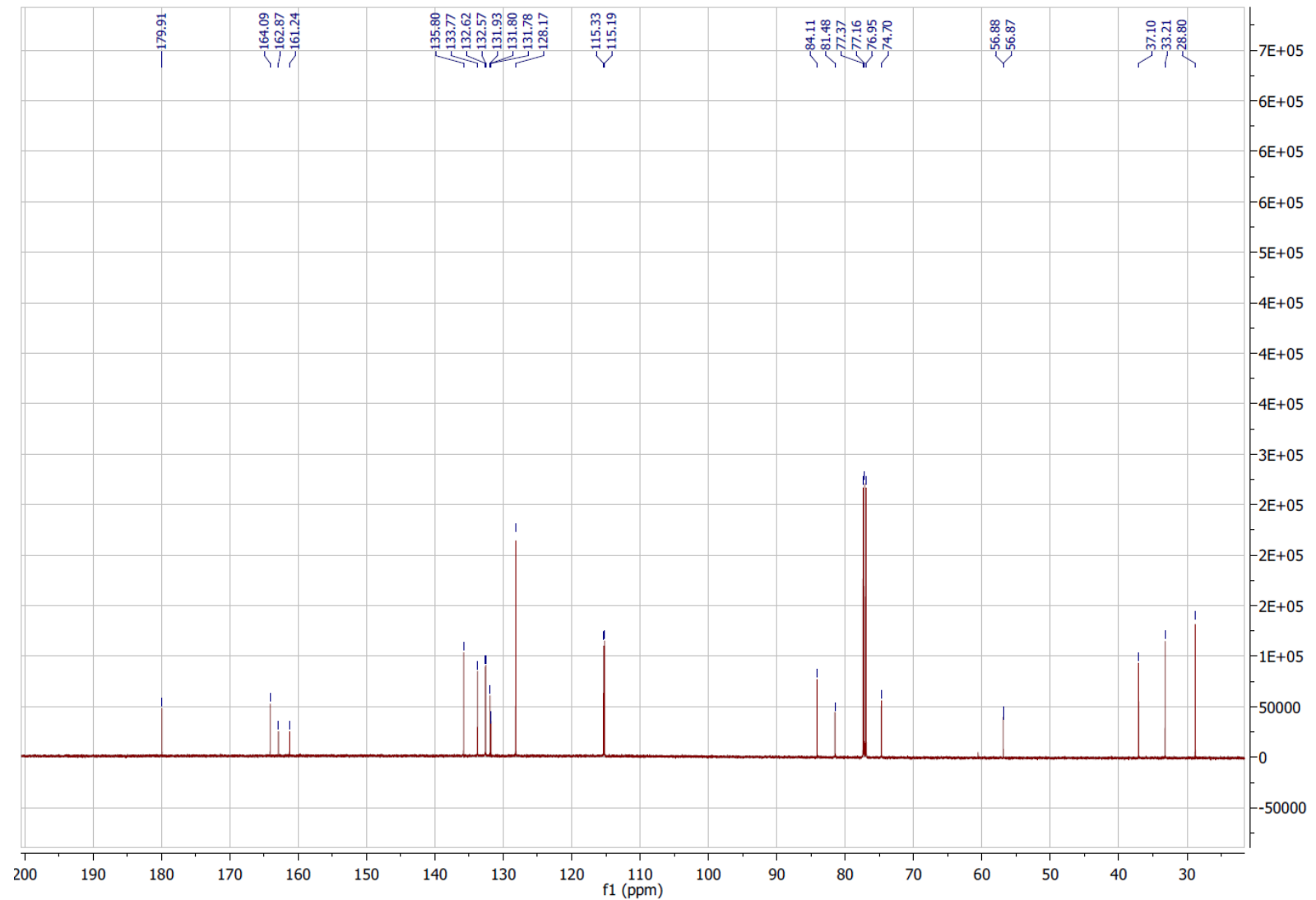


${ }^{1} \mathrm{H}$ NMR of 21n in $\mathrm{CDCl}_{3}(400 \mathrm{MHz})$

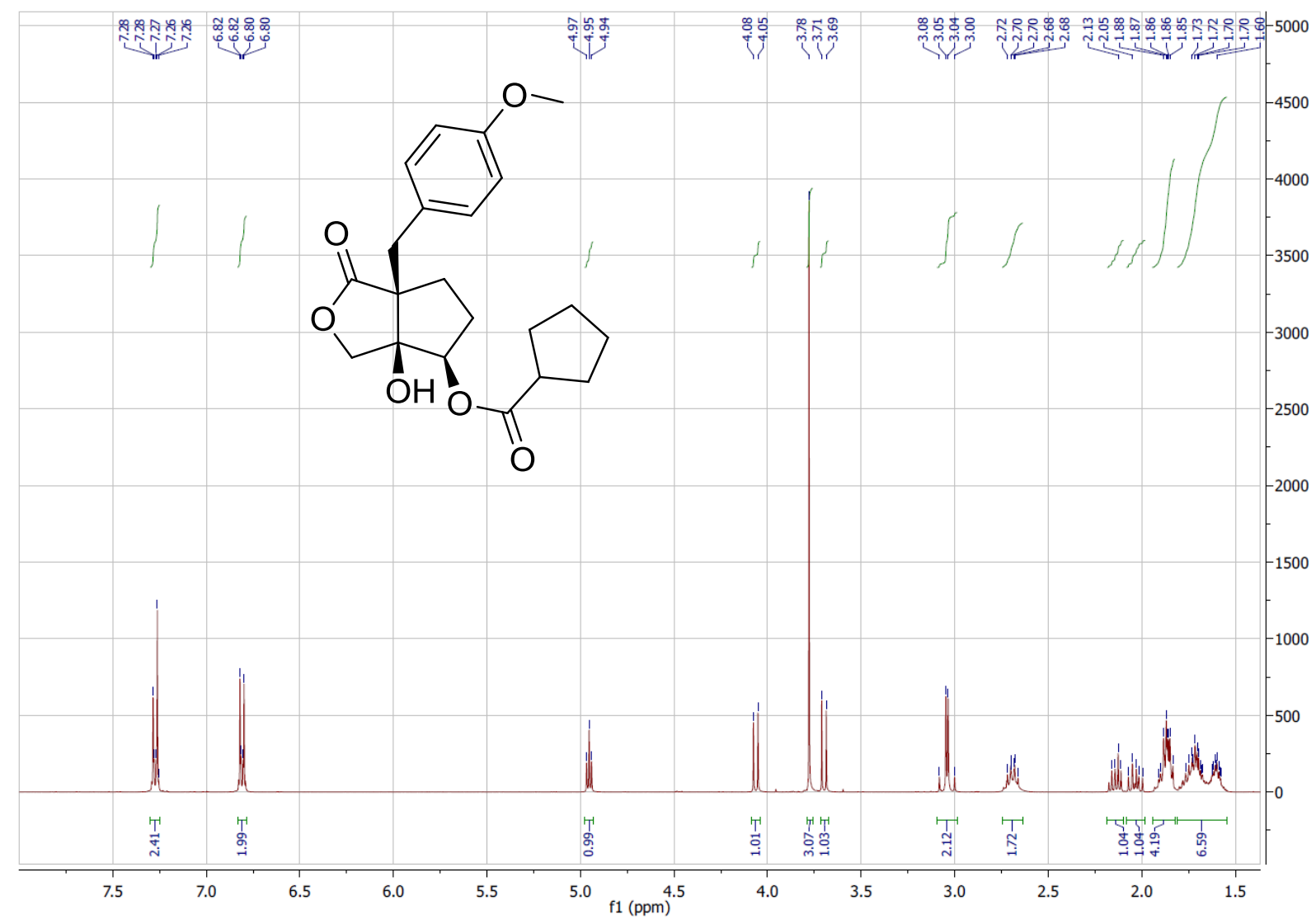

${ }^{13} \mathrm{C}$ NMR of $21 \mathrm{n}$ in $\mathrm{CDCl}_{3}(101 \mathrm{MHz})$

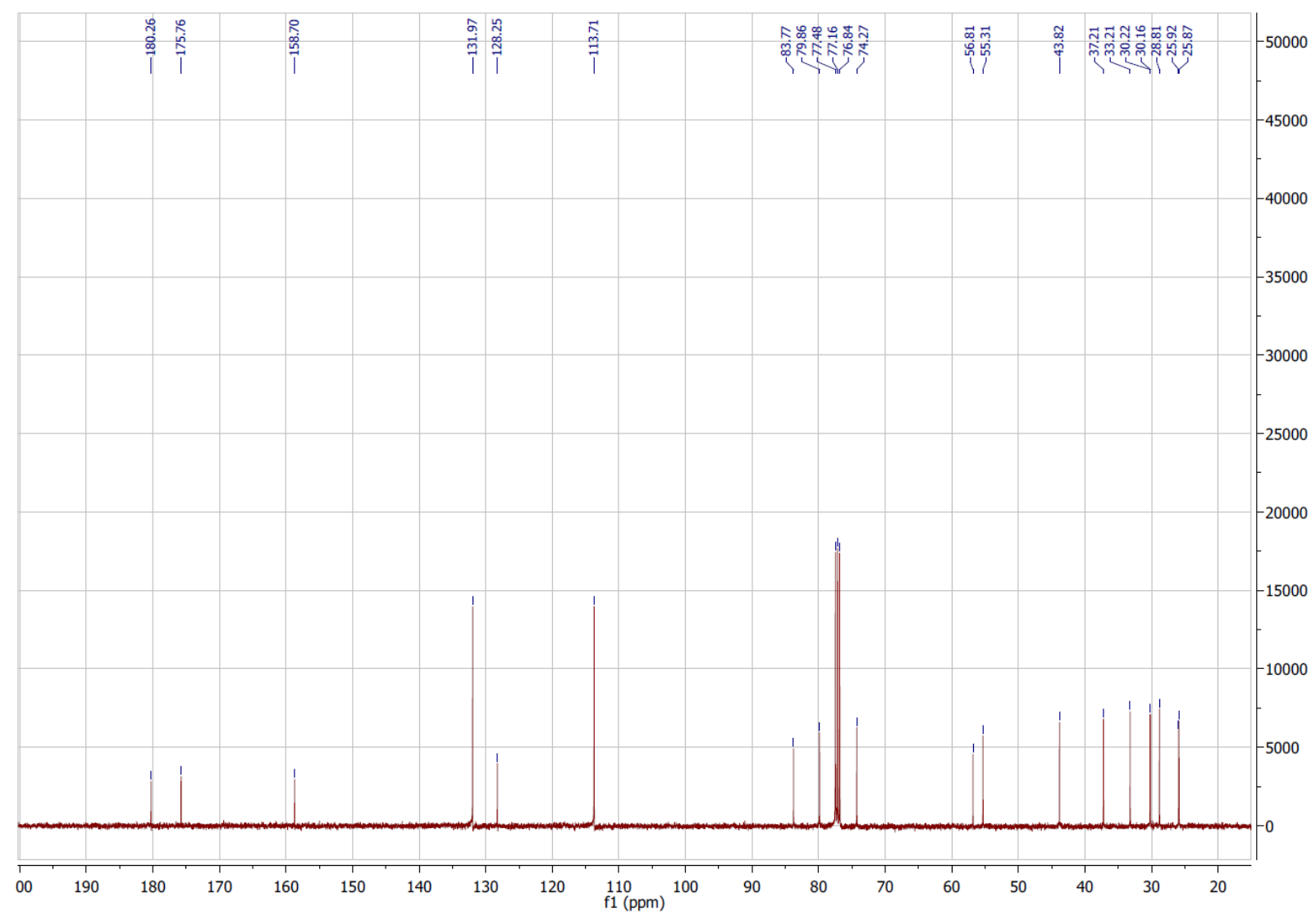


${ }^{1} \mathrm{H}$ NMR of 210 in $\mathrm{CDCl}_{3}(500 \mathrm{MHz})$

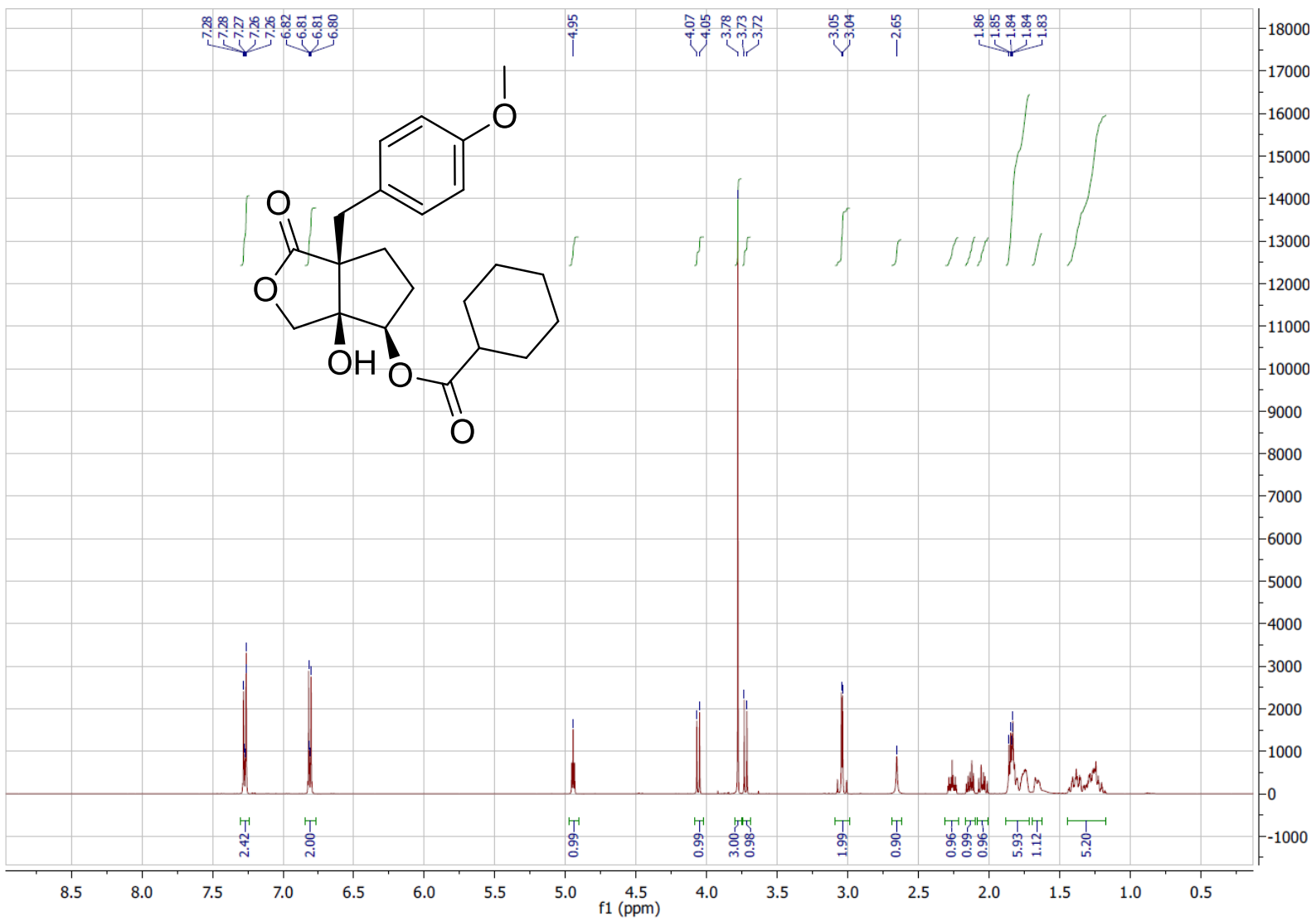

${ }^{13} \mathrm{C}$ NMR of 210 in $\mathrm{CDCl}_{3}(126 \mathrm{MHz})$

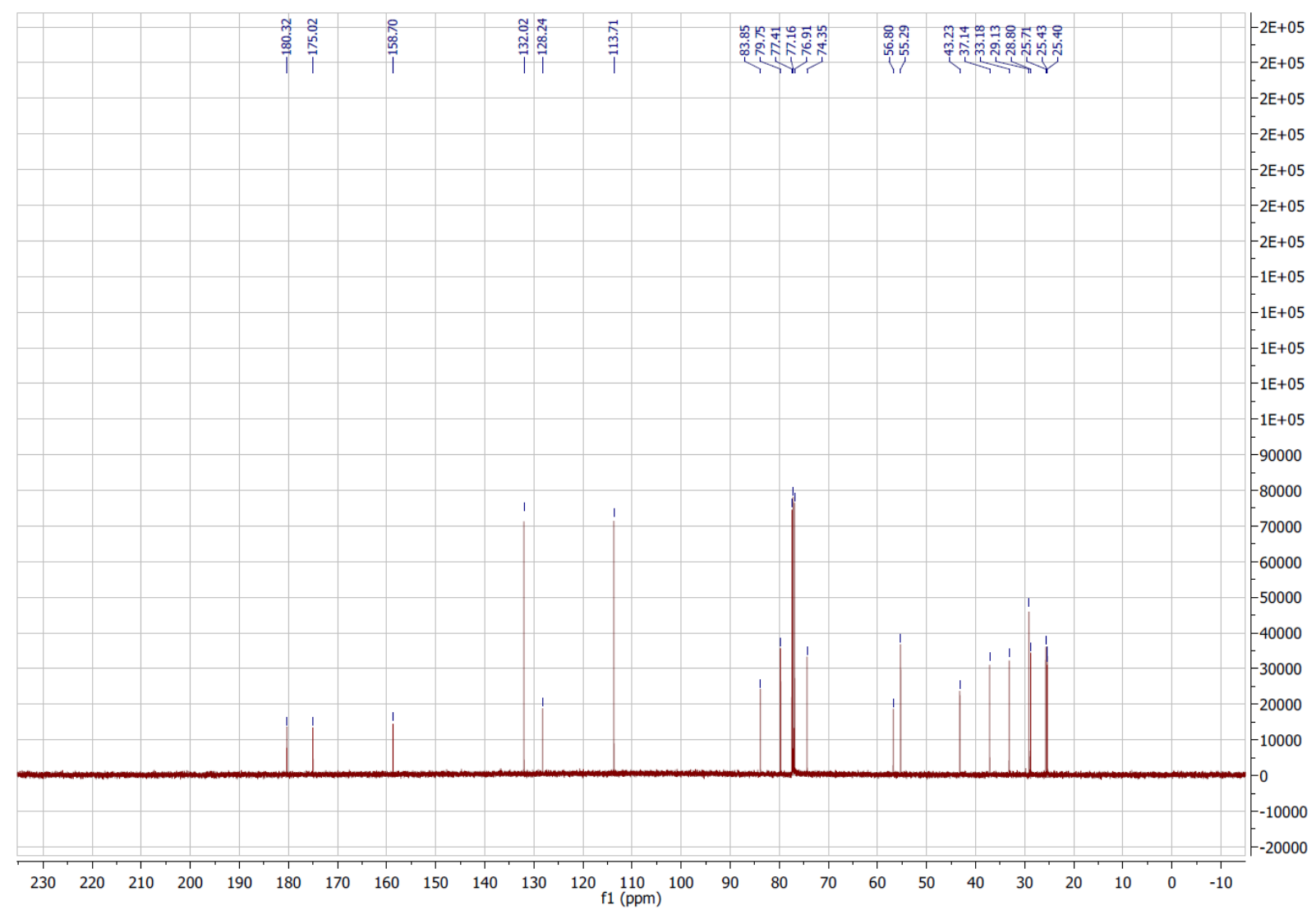


${ }^{1} \mathrm{H}$ NMR of 21p in $\mathrm{CDCl}_{3}(400 \mathrm{MHz})$

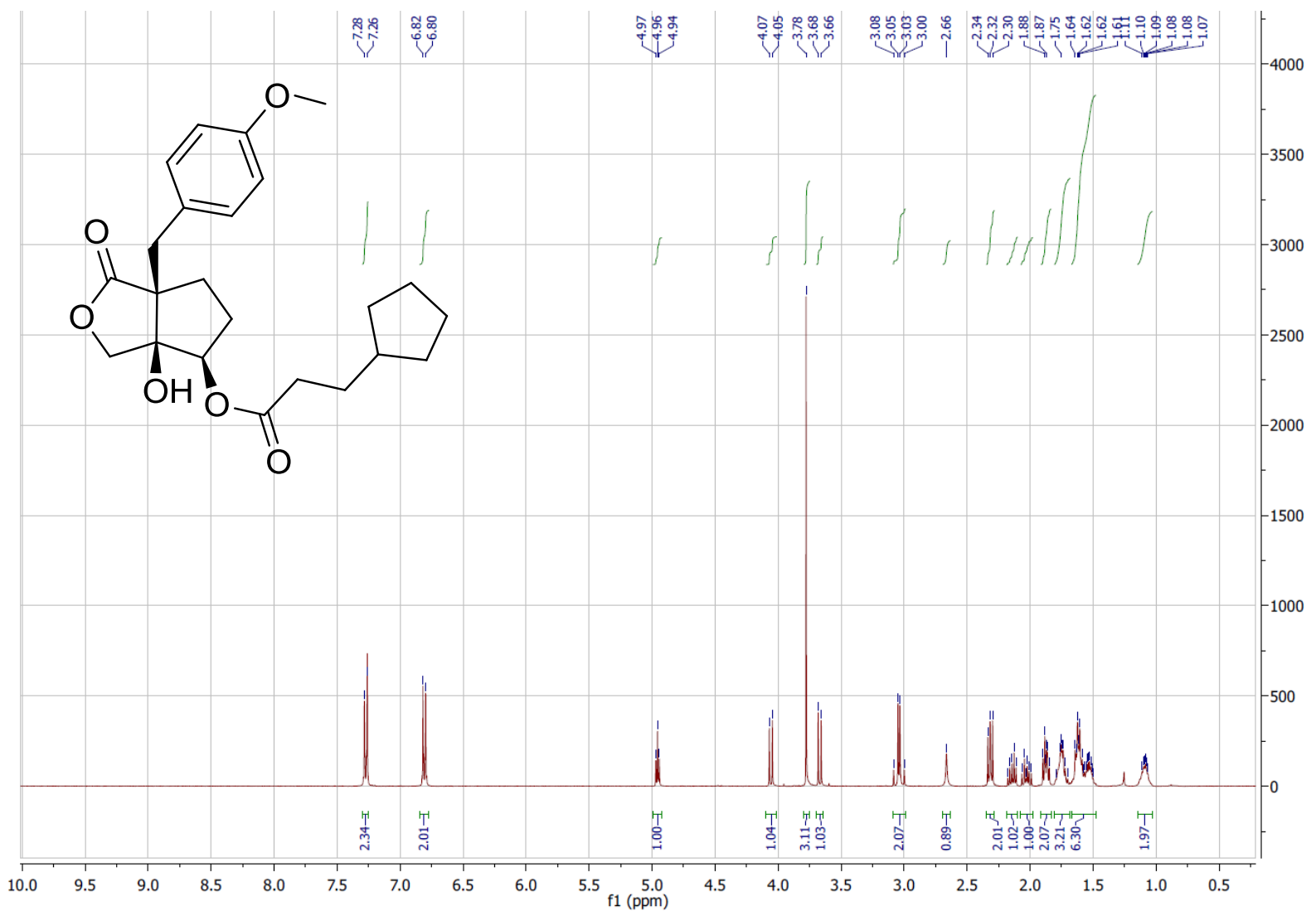

${ }^{13} \mathrm{C}$ NMR of 21p in $\mathrm{CDCl}_{3}(101 \mathrm{MHz})$

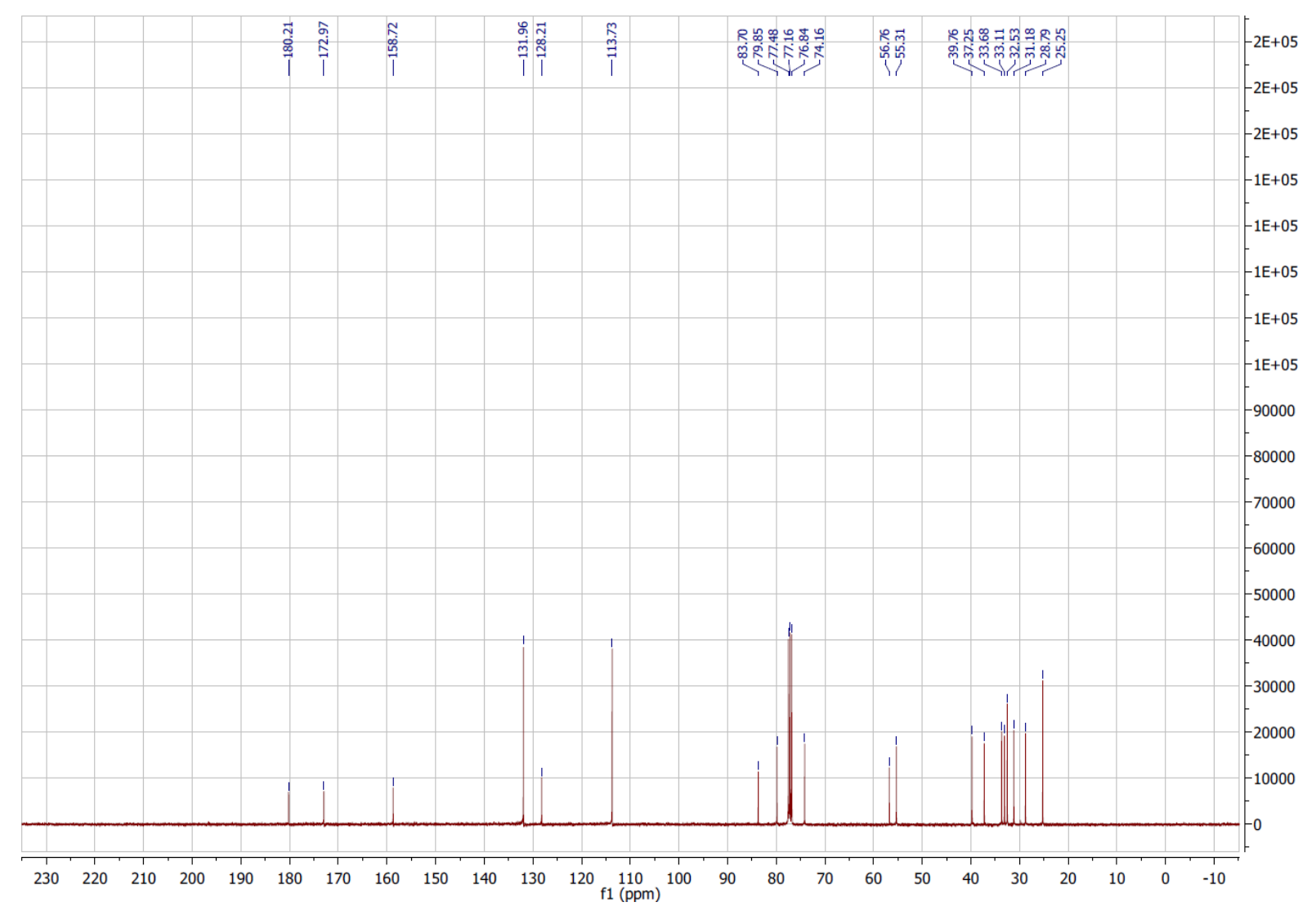


${ }^{1} \mathrm{H}$ NMR of 21q in $\mathrm{CDCl}_{3}(400 \mathrm{MHz})$

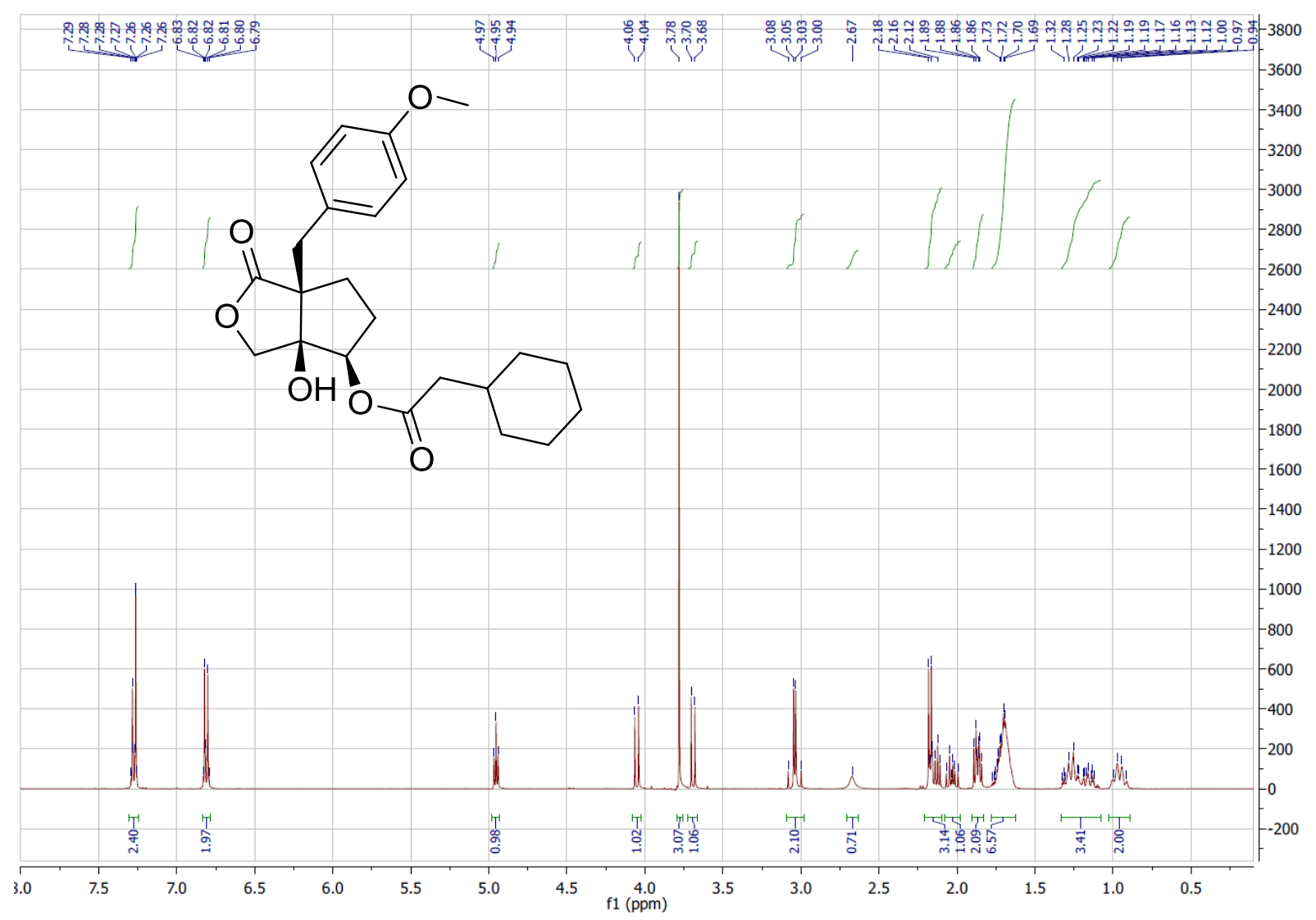

${ }^{13} \mathrm{C}$ NMR of $21 q$ in $\mathrm{CDCl}_{3}(101 \mathrm{MHz})$

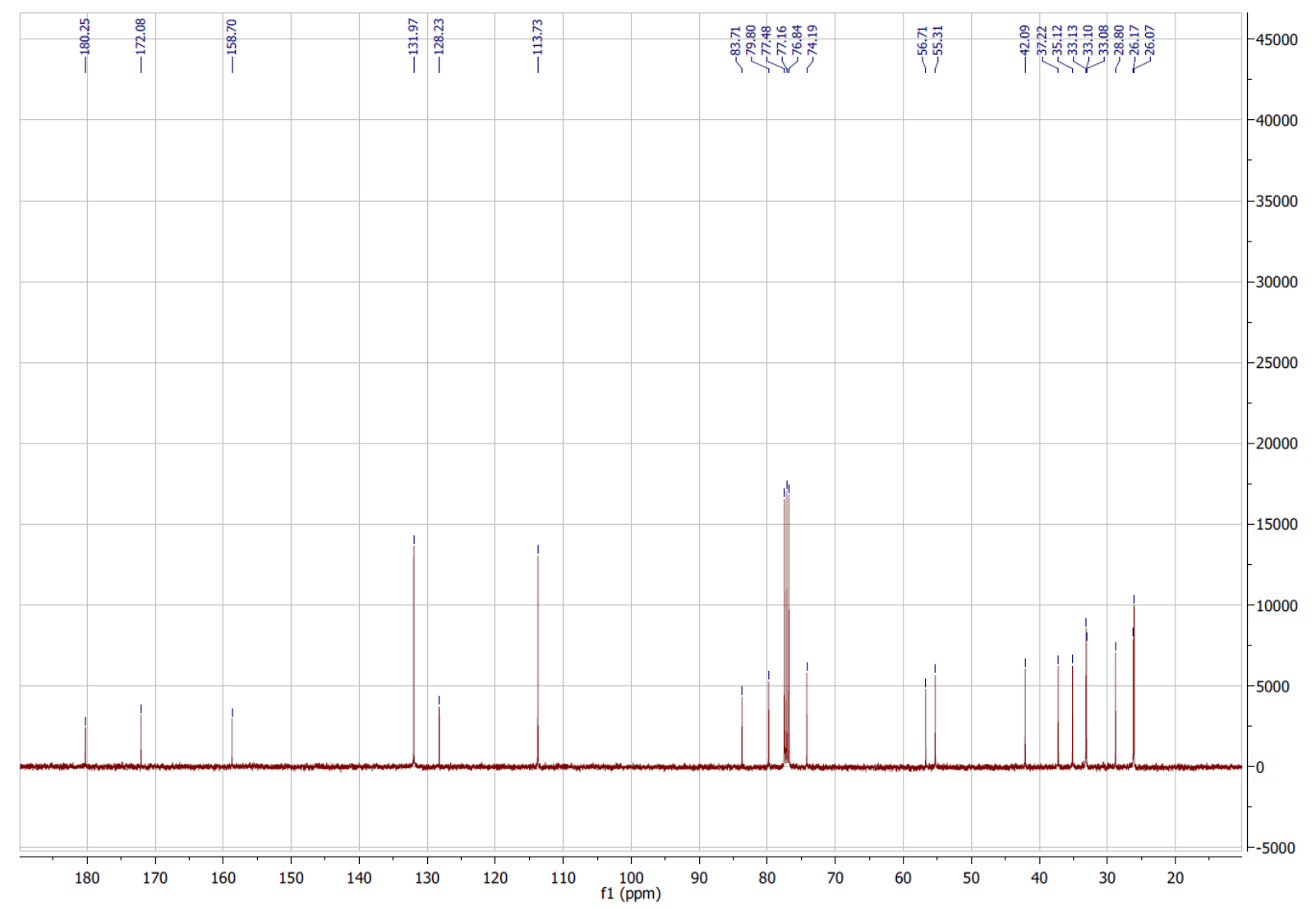


${ }^{1} \mathrm{H}$ NMR of $21 \mathbf{r}$ in $\mathrm{CDCl}_{3}(400 \mathrm{MHz})$

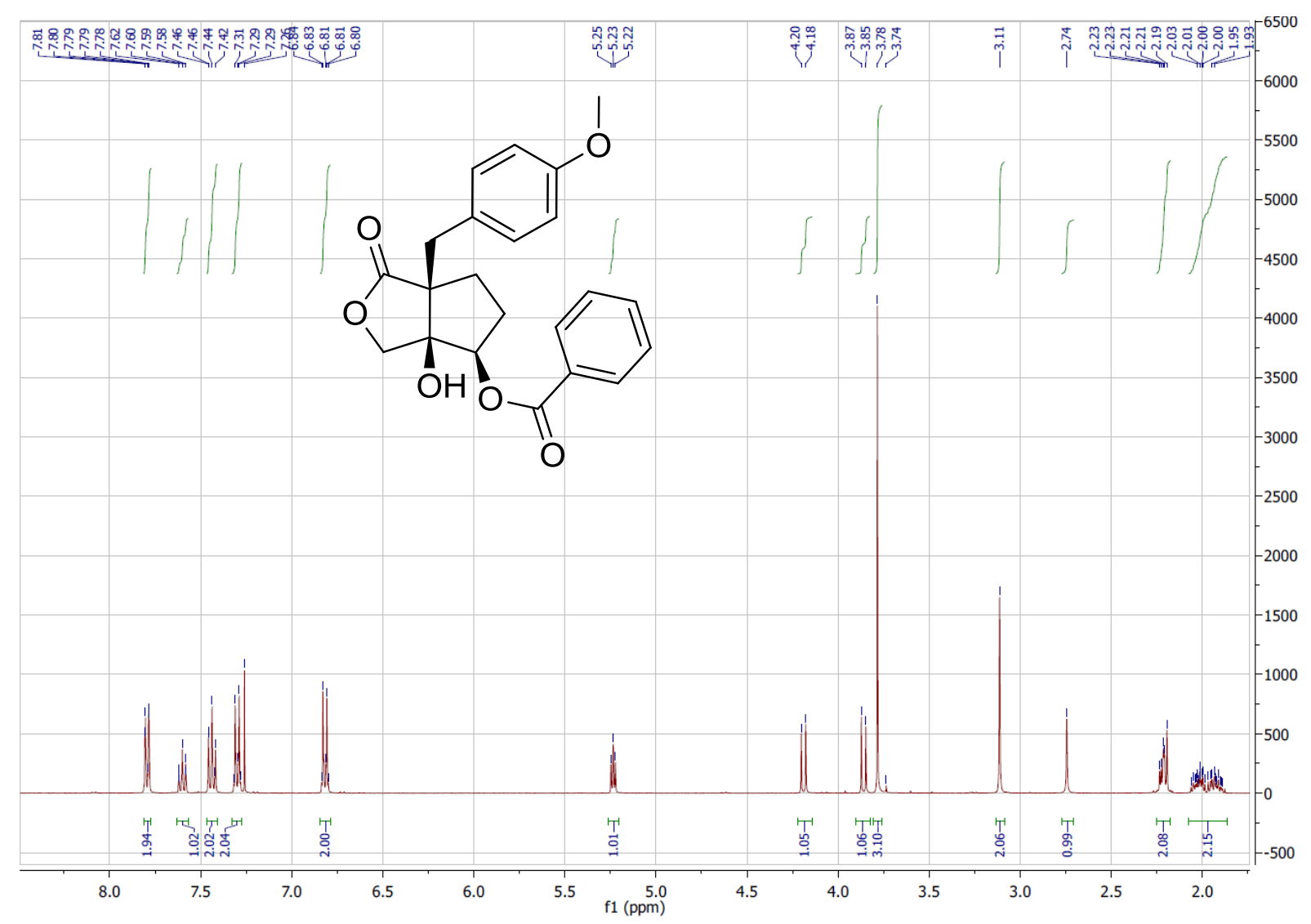

${ }^{13} \mathrm{C}$ NMR of $21 \mathbf{r}$ in $\mathrm{CDCl}_{3}(101 \mathrm{MHz})$

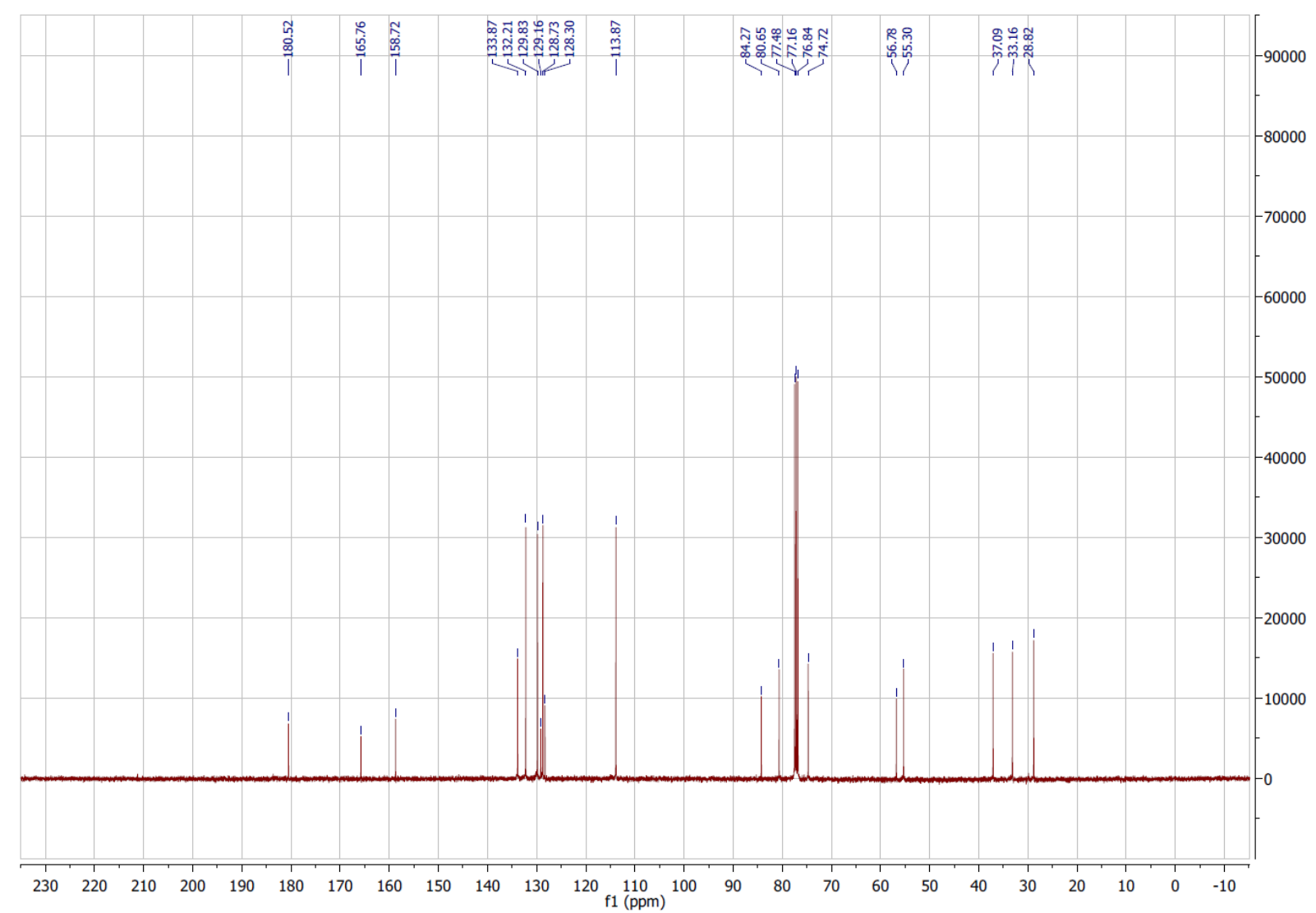


${ }^{1} \mathrm{H}$ NMR of 21s in $\mathrm{CDCl}_{3}(600 \mathrm{MHz})$

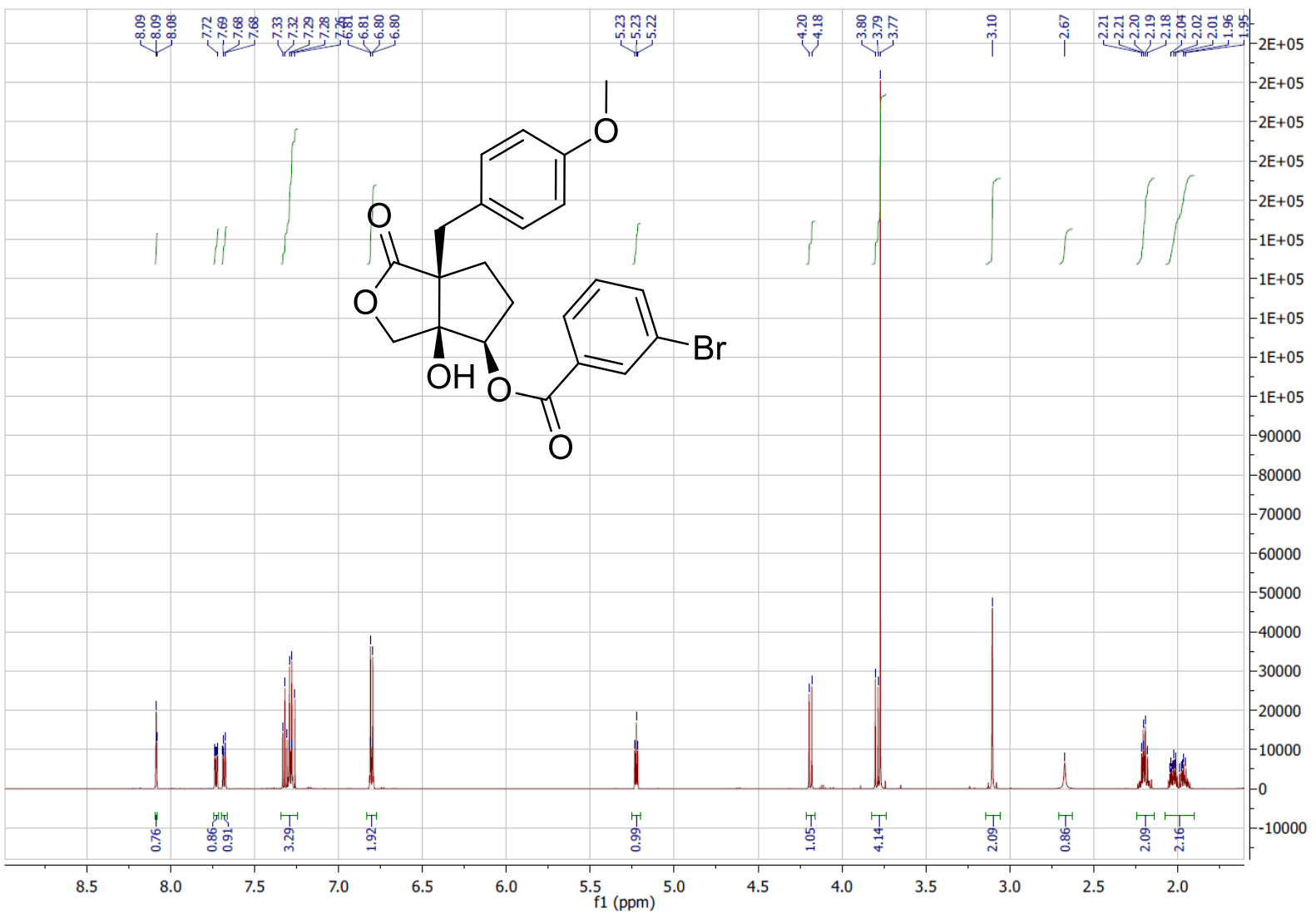

${ }^{13} \mathrm{C}$ NMR of 21s in $\mathrm{CDCl}_{3}(151 \mathrm{MHz})$

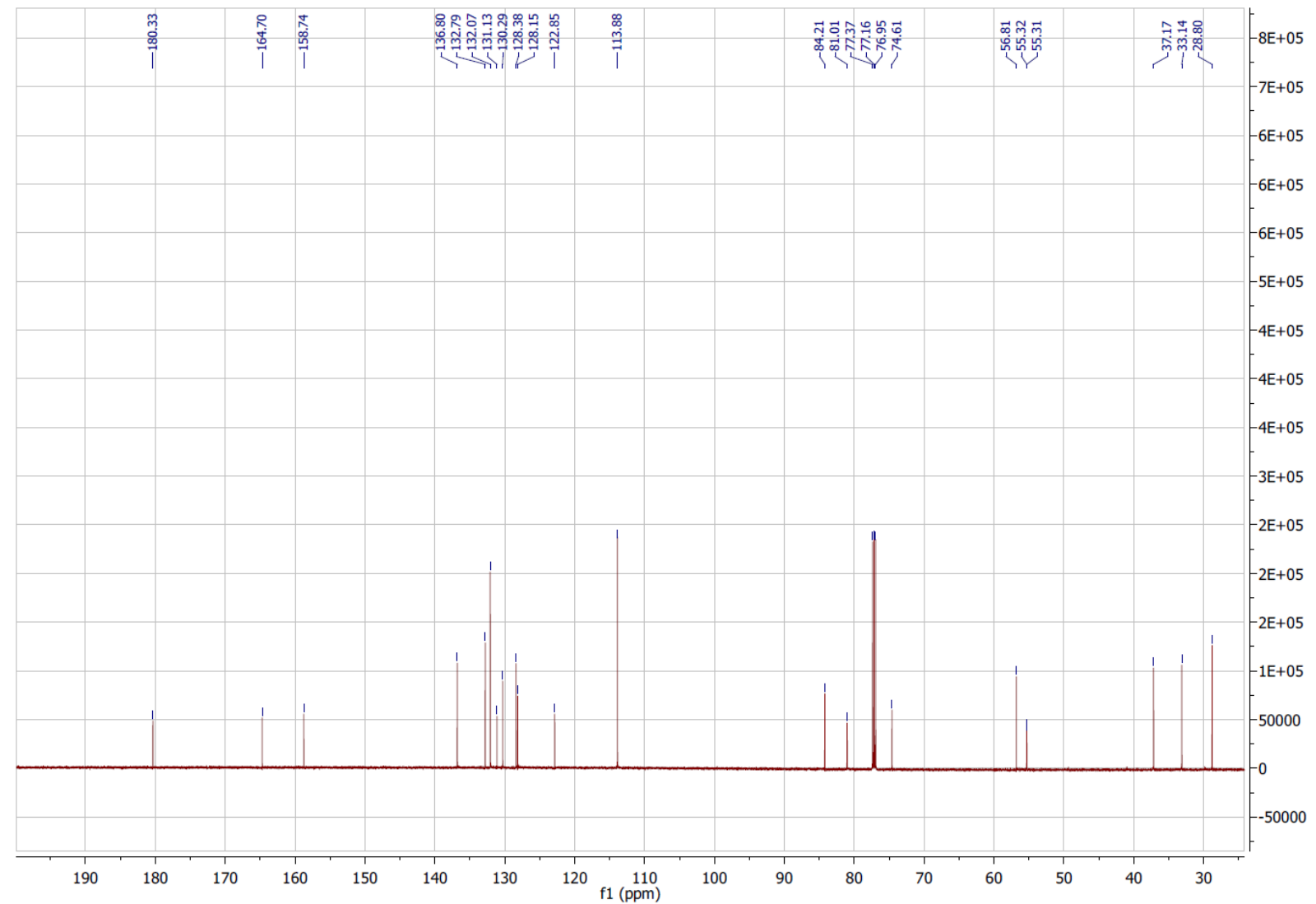


${ }^{1} \mathrm{H}$ NMR of 21t in $\mathrm{CDCl}_{3}(400 \mathrm{MHz})$

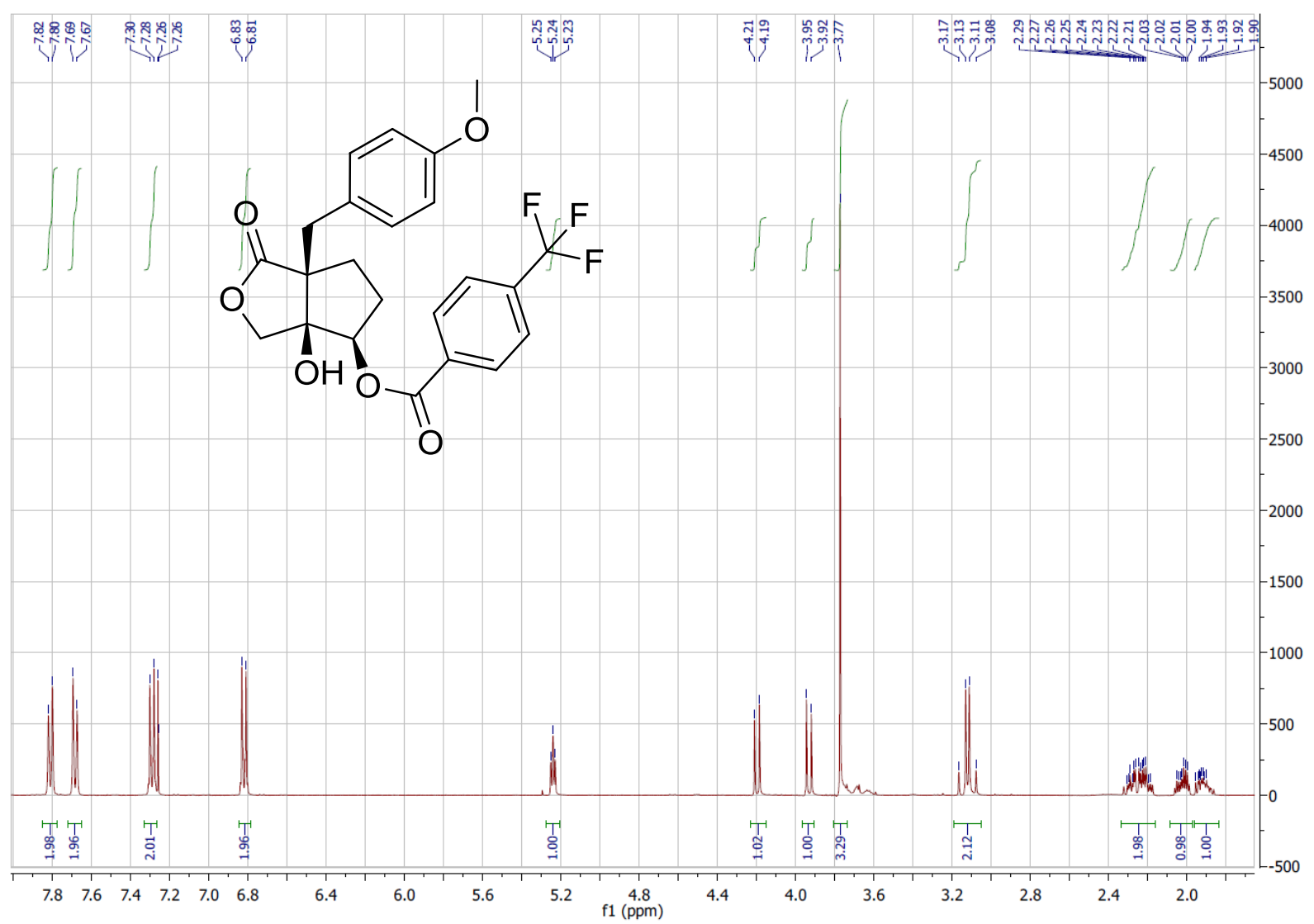

${ }^{13} \mathrm{C}$ NMR of 21t in $\mathrm{CDCl}_{3}(101 \mathrm{MHz})$

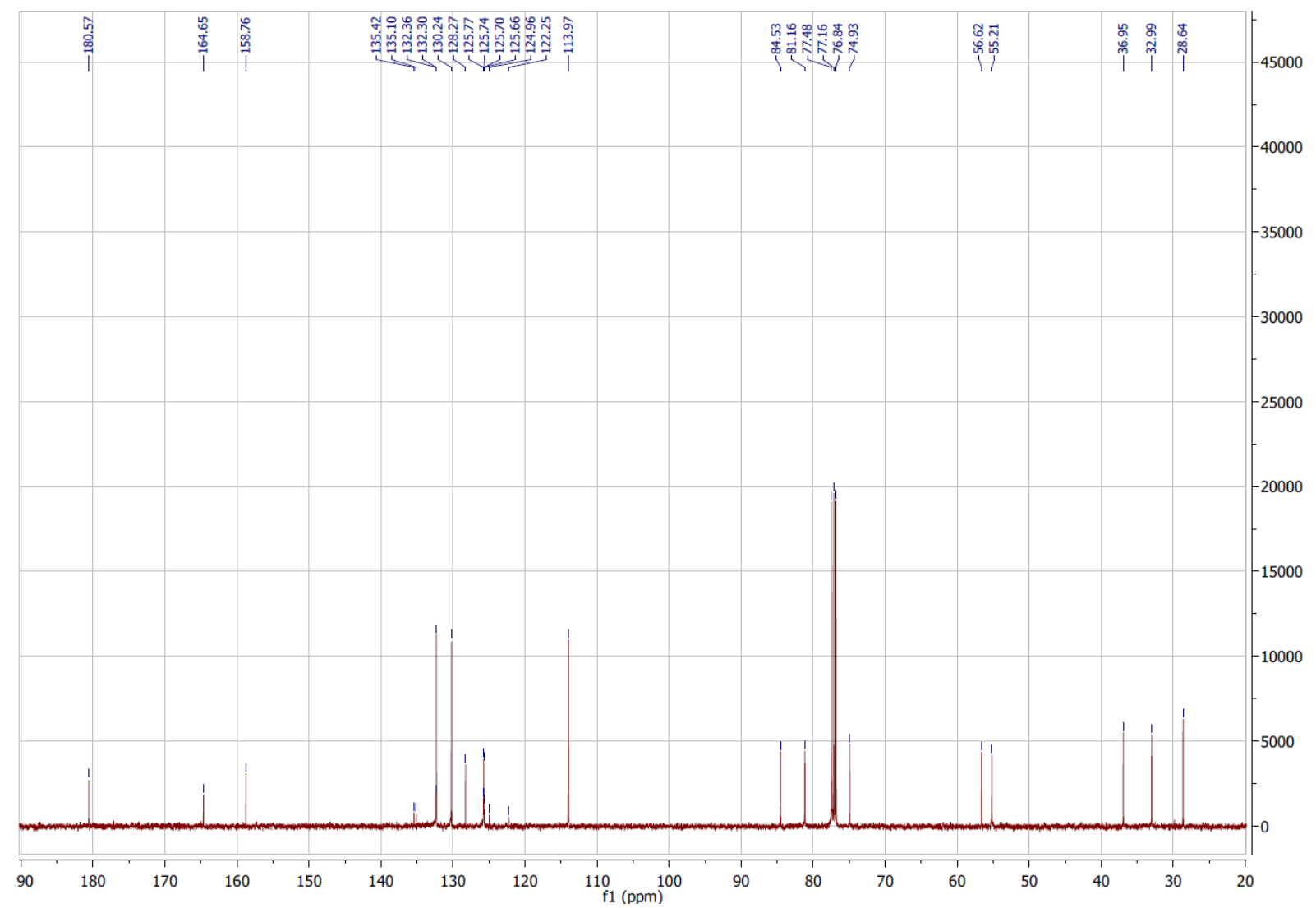


${ }^{1} \mathrm{H} \mathrm{NMR}$ of $21 \mathrm{u}$ in $\mathrm{CDCl}_{3}(500 \mathrm{MHz})$

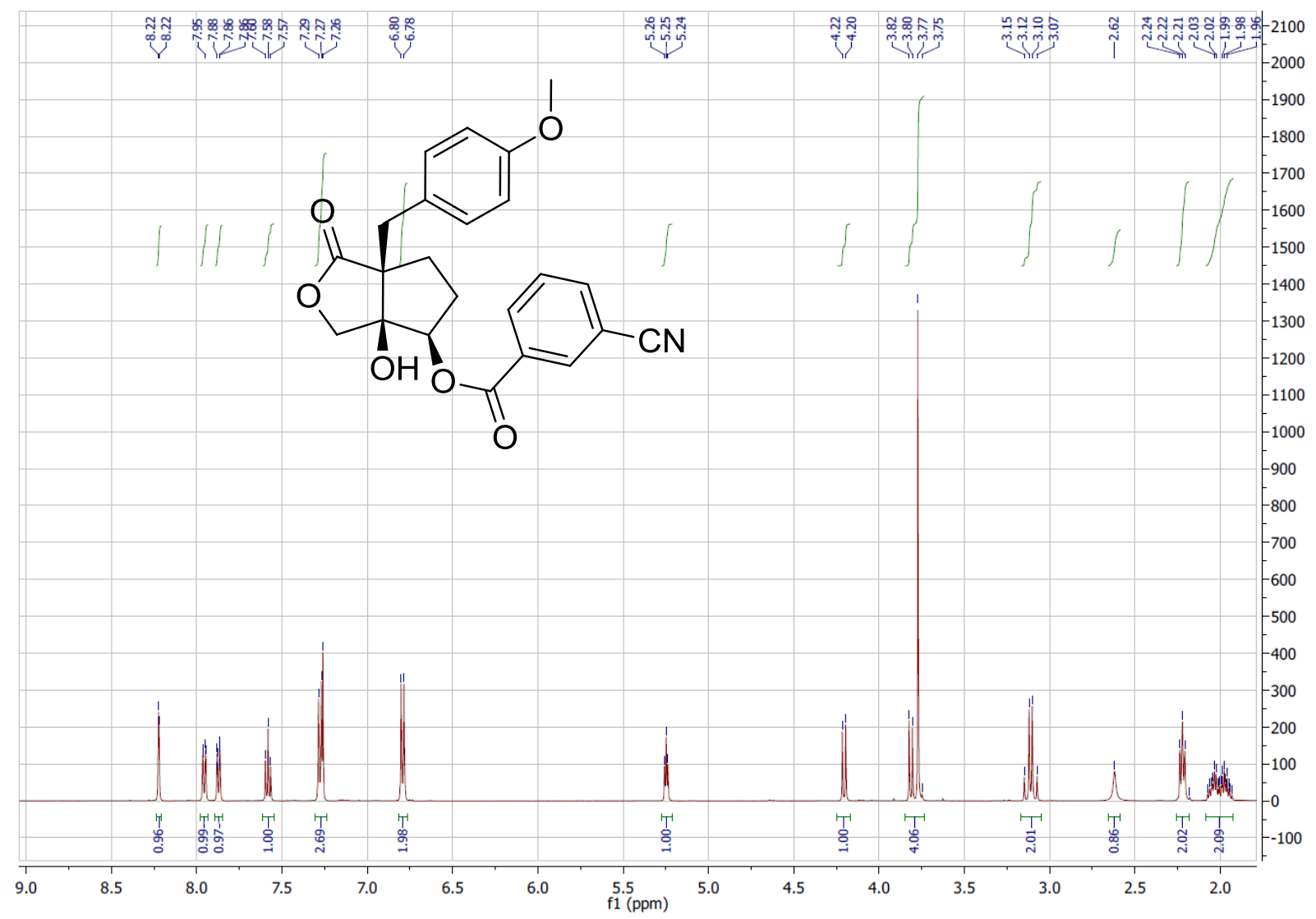

${ }^{13} \mathrm{C}$ NMR of $21 \mathbf{u}$ in $\mathrm{CDCl}_{3}(126 \mathrm{MHz})$

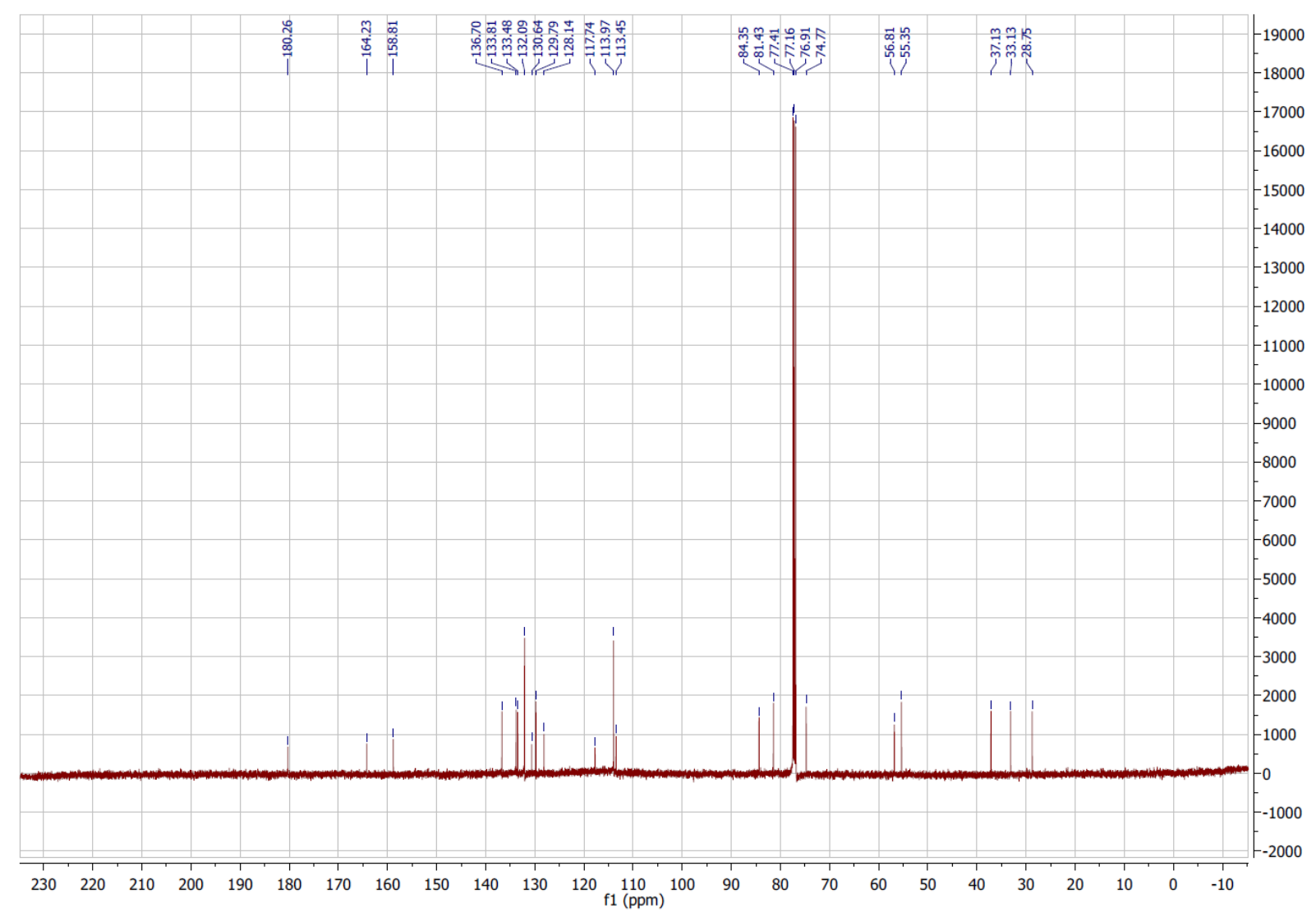


${ }^{1} \mathrm{H}$ NMR of 21v in $\mathrm{CDCl}_{3}(600 \mathrm{MHz})$

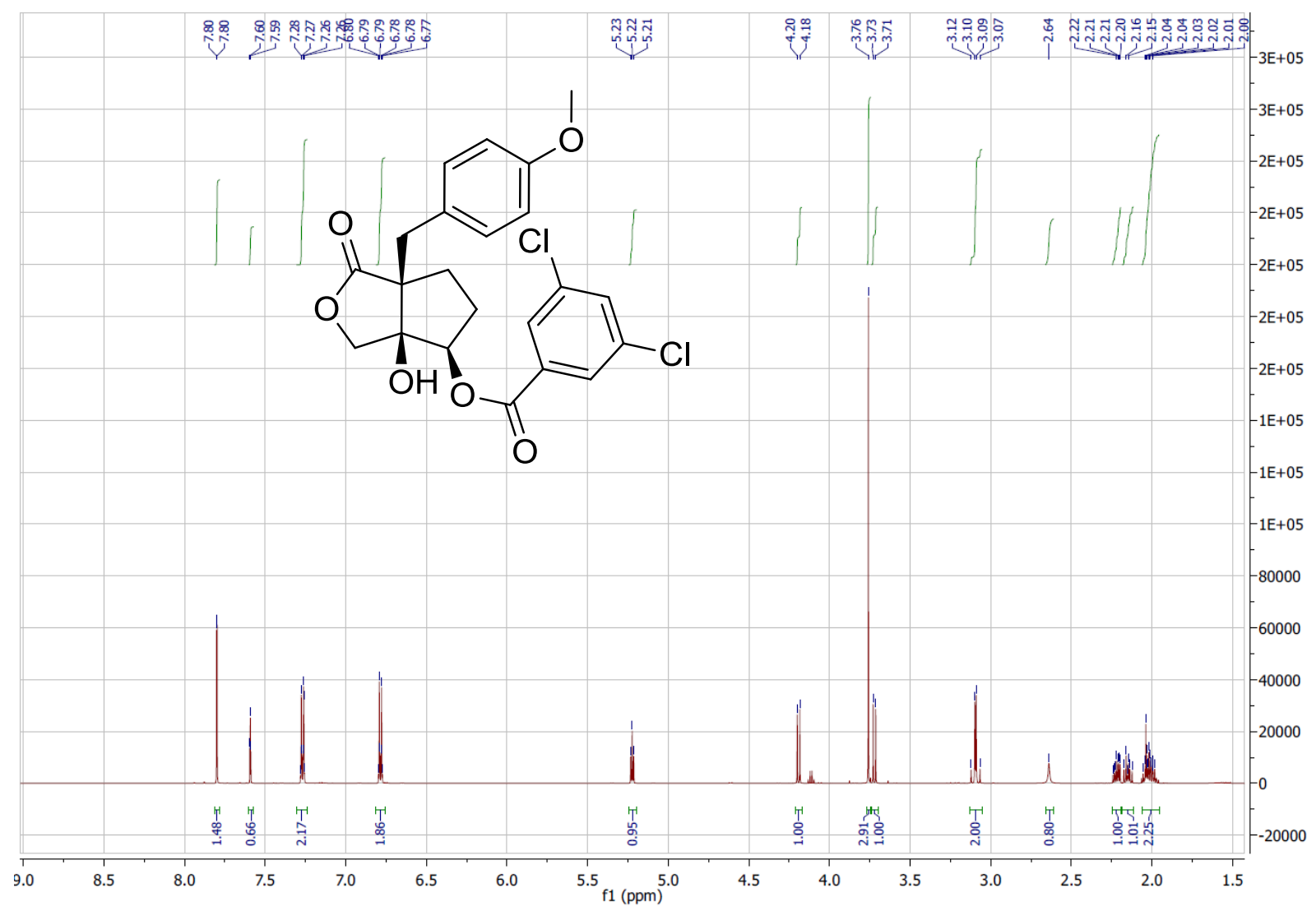

${ }^{13} \mathrm{C}$ NMR of $21 \mathbf{v}$ in $\mathrm{CDCl}_{3}(151 \mathrm{MHz})$

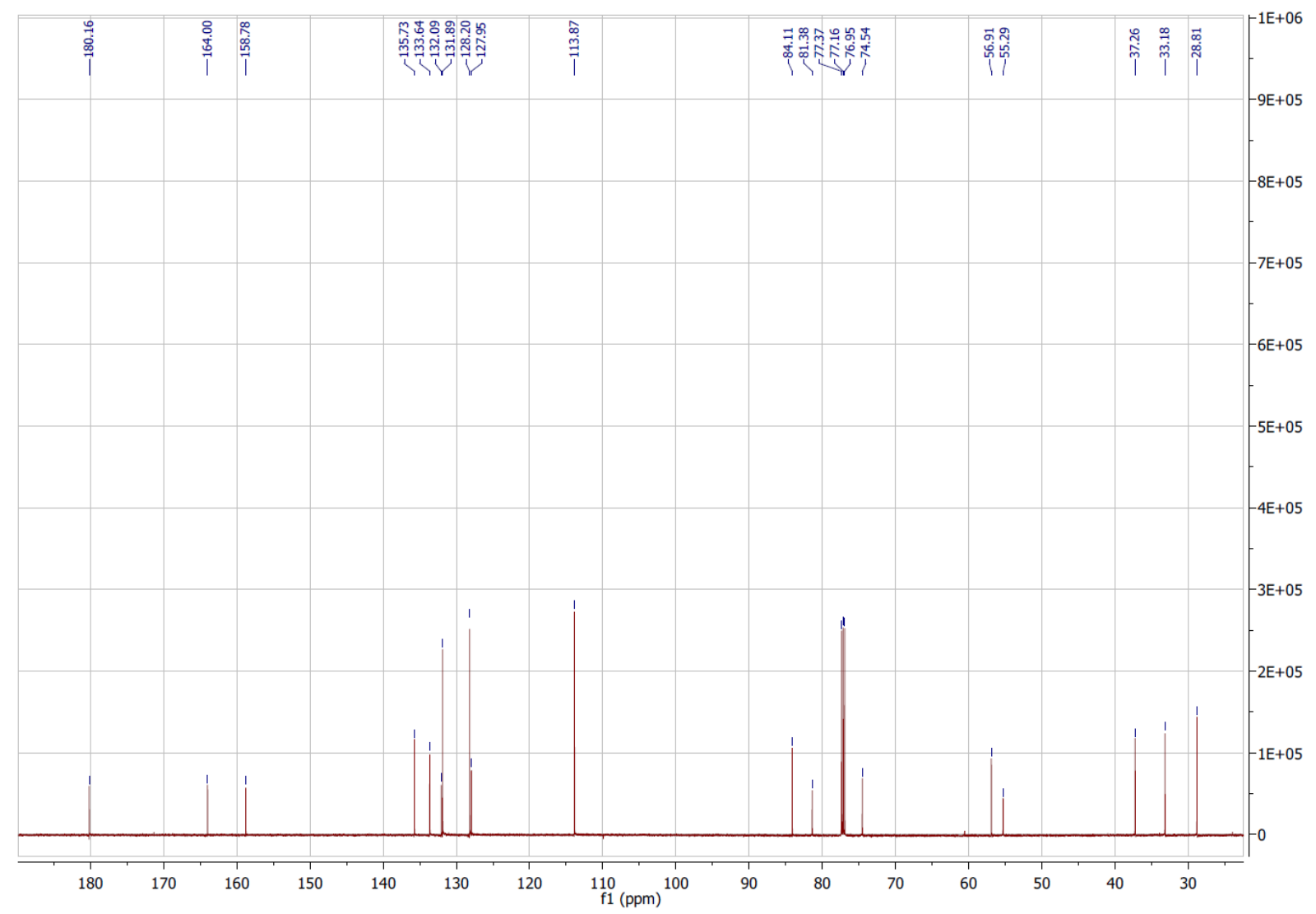




\section{Crystallographic Data}

\section{Compound 7b}

\section{CCDC 1480544}

Table 3: Crystal data and structure refinement for compound $\mathbf{7 b}$.

\section{$\mathrm{CCDC}$}

Empirical formula

Formula weight

Temperature

Wavelength

Crystal system

Space group

Unit cell dimensions

Volume

Z

Density (calculated)

Absorption coefficient

$\mathrm{F}(000)$

Crystal size

Theta range for data collection

Index ranges

Reflections collected

Independent reflections

Completeness to theta $=26.00^{\circ}$

Max. and min. transmission

Refinement method

Data / restraints / parameters

Goodness-of-fit on $\mathrm{F}^{2}$

Final $\mathrm{R}$ indices [I $>2 \operatorname{sigma}(\mathrm{I})]$

$\mathrm{R}$ indices (all data)

Largest diff. peak and hole
$\mathrm{C}_{13} \mathrm{H}_{22} \mathrm{O}_{4}$

$242.31 \mathrm{~g} / \mathrm{mol}$

173(2) K

$0.71073 \AA$

Monoclinic

$P 21 /$ n (14)

$\mathrm{a}=8.8789(5) \AA$

$\alpha=90^{\circ}$.

$\mathrm{b}=11.4732(7) \AA$

$\beta=90.436(5)^{\circ}$.

$\mathrm{c}=12.3178(7) \AA$

$\gamma=90^{\circ}$.

1254.77(13) $\AA^{3}$

4

$1.283 \mathrm{Mg} / \mathrm{m}^{3}$

$0.093 \mathrm{~mm}^{-1}$

528

$0.40 \times 0.20 \times 0.20 \mathrm{~mm}^{3}$

2.43 to $26.00^{\circ}$.

$-10<=\mathrm{h}<=10,-14<=\mathrm{k}<=14,-15<=\mathrm{l}<=15$

12499

$2459[\mathrm{R}(\mathrm{int})=0.0367]$

$100.0 \%$

0.9815 and 0.9636

Full-matrix least-squares on $\mathrm{F}^{2}$

2459 / 0 / 165

1.007

$\mathrm{R} 1=0.0389, \mathrm{wR} 2=0.0930$

$\mathrm{R} 1=0.0594, \mathrm{wR} 2=0.0968$

0.251 and -0.172 e. $\AA^{-3}$ 
Table 4: Atomic coordinates $\left(\mathrm{x} 10^{4}\right)$ and equivalent isotropic displacement parameters $\left(\AA^{2} \mathrm{x}\right.$ $10^{3}$ ) for compound $\mathbf{7 b}$. U(eq) is defined as one third of the trace of the orthogonalized $\mathrm{U}^{\mathrm{ij}}$ tensor.

\begin{tabular}{lrrrl}
\hline & $\mathrm{x}$ & $\mathrm{y}$ & $\mathrm{z}$ & $\mathrm{U}(\mathrm{eq})$ \\
\hline $\mathrm{C}(1)$ & $638(2)$ & $2014(1)$ & $5377(1)$ & $21(1)$ \\
$\mathrm{C}(2)$ & $-545(2)$ & $2348(1)$ & $4549(1)$ & $20(1)$ \\
$\mathrm{C}(3)$ & $-1127(2)$ & $1210(1)$ & $4011(1)$ & $30(1)$ \\
$\mathrm{C}(4)$ & $-1720(2)$ & $1558(1)$ & $2884(1)$ & $27(1)$ \\
$\mathrm{C}(5)$ & $-1106(2)$ & $2774(1)$ & $2643(1)$ & $24(1)$ \\
$\mathrm{C}(6)$ & $43(2)$ & $3037(1)$ & $3555(1)$ & $20(1)$ \\
$\mathrm{C}(7)$ & $1585(2)$ & $2580(1)$ & $3241(1)$ & $22(1)$ \\
$\mathrm{C}(8)$ & $2732(2)$ & $2549(1)$ & $4163(1)$ & $23(1)$ \\
$\mathrm{C}(9)$ & $-1808(2)$ & $2995(2)$ & $5134(1)$ & $31(1)$ \\
$\mathrm{C}(10)$ & $3182(2)$ & $3750(1)$ & $4598(1)$ & $28(1)$ \\
$\mathrm{C}(11)$ & $3989(2)$ & $4513(2)$ & $3782(1)$ & $33(1)$ \\
$\mathrm{C}(12)$ & $4128(2)$ & $1845(2)$ & $3890(1)$ & $32(1)$ \\
$\mathrm{C}(13)$ & $3901(2)$ & $570(2)$ & $3678(2)$ & $48(1)$ \\
$\mathrm{O}(1)$ & $2087(1)$ & $1944(1)$ & $5110(1)$ & $26(1)$ \\
$\mathrm{O}(2)$ & $320(1)$ & $1720(1)$ & $6292(1)$ & $31(1)$ \\
$\mathrm{O}(3)$ & $-2220(1)$ & $3659(1)$ & $2689(1)$ & $36(1)$ \\
$\mathrm{O}(4)$ & $153(1)$ & $4252(1)$ & $3749(1)$ & $27(1)$ \\
\hline
\end{tabular}

Table 5: Bond lengths $[\AA]$ and angles $\left[{ }^{\circ}\right]$.

\begin{tabular}{lc}
\hline $\mathrm{C}(1)-\mathrm{O}(2)$ & $1.2114(17)$ \\
$\mathrm{C}(1)-\mathrm{O}(1)$ & $1.3331(16)$ \\
$\mathrm{C}(1)-\mathrm{C}(2)$ & $1.508(2)$ \\
$\mathrm{C}(2)-\mathrm{C}(9)$ & $1.530(2)$ \\
$\mathrm{C}(2)-\mathrm{C}(3)$ & $1.551(2)$ \\
$\mathrm{C}(2)-\mathrm{C}(6)$ & $1.551(2)$ \\
$\mathrm{C}(3)-\mathrm{C}(4)$ & $1.533(2)$ \\
$\mathrm{C}(4)-\mathrm{C}(5)$ & $1.528(2)$ \\
$\mathrm{C}(5)-\mathrm{O}(3)$ & $1.4196(18)$ \\
$\mathrm{C}(5)-\mathrm{C}(6)$ & $1.542(2)$ \\
$\mathrm{C}(6)-\mathrm{O}(4)$ & $1.4176(18)$ \\
$\mathrm{C}(6)-\mathrm{C}(7)$ & $1.5192(19)$
\end{tabular}




\begin{tabular}{|c|c|}
\hline$C(7)-C(8)$ & $1.521(2)$ \\
\hline $\mathrm{C}(8)-\mathrm{O}(1)$ & $1.4766(17)$ \\
\hline $\mathrm{C}(8)-\mathrm{C}(12)$ & $1.519(2)$ \\
\hline C(8)-C(10) & $1.530(2)$ \\
\hline$C(10)-C(11)$ & $1.517(2)$ \\
\hline $\mathrm{C}(12)-\mathrm{C}(13)$ & $1.499(2)$ \\
\hline $\mathrm{O}(2)-\mathrm{C}(1)-\mathrm{O}(1)$ & $116.43(13)$ \\
\hline $\mathrm{O}(2)-\mathrm{C}(1)-\mathrm{C}(2)$ & $122.29(13)$ \\
\hline $\mathrm{O}(1)-\mathrm{C}(1)-\mathrm{C}(2)$ & $121.09(12)$ \\
\hline $\mathrm{C}(1)-\mathrm{C}(2)-\mathrm{C}(9)$ & $108.29(12)$ \\
\hline $\mathrm{C}(1)-\mathrm{C}(2)-\mathrm{C}(3)$ & $107.67(12)$ \\
\hline $\mathrm{C}(9)-\mathrm{C}(2)-\mathrm{C}(3)$ & $111.52(12)$ \\
\hline $\mathrm{C}(1)-\mathrm{C}(2)-\mathrm{C}(6)$ & $115.29(12)$ \\
\hline $\mathrm{C}(9)-\mathrm{C}(2)-\mathrm{C}(6)$ & $112.09(13)$ \\
\hline$C(3)-C(2)-C(6)$ & $101.80(11)$ \\
\hline$C(4)-C(3)-C(2)$ & $106.20(12)$ \\
\hline $\mathrm{C}(5)-\mathrm{C}(4)-\mathrm{C}(3)$ & $107.06(12)$ \\
\hline $\mathrm{O}(3)-\mathrm{C}(5)-\mathrm{C}(4)$ & $113.35(12)$ \\
\hline $\mathrm{O}(3)-\mathrm{C}(5)-\mathrm{C}(6)$ & $106.69(12)$ \\
\hline$C(4)-C(5)-C(6)$ & $105.78(12)$ \\
\hline $\mathrm{O}(4)-\mathrm{C}(6)-\mathrm{C}(7)$ & $108.76(11)$ \\
\hline $\mathrm{O}(4)-\mathrm{C}(6)-\mathrm{C}(5)$ & $111.10(12)$ \\
\hline $\mathrm{C}(7)-\mathrm{C}(6)-\mathrm{C}(5)$ & $109.82(11)$ \\
\hline $\mathrm{O}(4)-\mathrm{C}(6)-\mathrm{C}(2)$ & $113.06(11)$ \\
\hline $\mathrm{C}(7)-\mathrm{C}(6)-\mathrm{C}(2)$ & $109.50(12)$ \\
\hline$C(5)-C(6)-C(2)$ & $104.52(12)$ \\
\hline $\mathrm{C}(6)-\mathrm{C}(7)-\mathrm{C}(8)$ & $114.68(12)$ \\
\hline $\mathrm{O}(1)-\mathrm{C}(8)-\mathrm{C}(12)$ & $104.33(12)$ \\
\hline $\mathrm{O}(1)-\mathrm{C}(8)-\mathrm{C}(7)$ & $109.83(11)$ \\
\hline $\mathrm{C}(12)-\mathrm{C}(8)-\mathrm{C}(7)$ & $112.93(13)$ \\
\hline $\mathrm{O}(1)-\mathrm{C}(8)-\mathrm{C}(10)$ & $104.40(12)$ \\
\hline $\mathrm{C}(12)-\mathrm{C}(8)-\mathrm{C}(10)$ & $110.18(12)$ \\
\hline $\mathrm{C}(7)-\mathrm{C}(8)-\mathrm{C}(10)$ & $114.35(13)$ \\
\hline $\mathrm{C}(11)-\mathrm{C}(10)-\mathrm{C}(8)$ & $114.30(13)$ \\
\hline $\mathrm{C}(13)-\mathrm{C}(12)-\mathrm{C}(8)$ & $116.67(14)$ \\
\hline $\mathrm{C}(1)-\mathrm{O}(1)-\mathrm{C}(8)$ & $123.23(11)$ \\
\hline
\end{tabular}


Table 6: Anisotropic displacement parameters $\left(\AA^{2} \times 10^{3}\right)$ for compound $7 \mathbf{b}$. The anisotropic displacement factor exponent takes the form: $-2 \pi^{2}\left[h^{2} a^{*} U^{11}+\ldots+2 h k a^{*} b^{*} U^{12}\right]$.

\begin{tabular}{lcccccc}
\hline & $\mathrm{U}^{11}$ & $\mathrm{U}^{22}$ & $\mathrm{U}^{33}$ & $\mathrm{U}^{23}$ & $\mathrm{U}^{13}$ & $\mathrm{U}^{12}$ \\
\hline $\mathrm{C}(1)$ & $23(1)$ & $19(1)$ & $20(1)$ & $-2(1)$ & $1(1)$ & $-3(1)$ \\
$\mathrm{C}(2)$ & $19(1)$ & $23(1)$ & $18(1)$ & $-1(1)$ & $1(1)$ & $-1(1)$ \\
$\mathrm{C}(3)$ & $30(1)$ & $26(1)$ & $32(1)$ & $0(1)$ & $-3(1)$ & $-9(1)$ \\
$\mathrm{C}(4)$ & $25(1)$ & $30(1)$ & $26(1)$ & $-7(1)$ & $-3(1)$ & $-2(1)$ \\
$\mathrm{C}(5)$ & $22(1)$ & $29(1)$ & $19(1)$ & $-4(1)$ & $-3(1)$ & $1(1)$ \\
$\mathrm{C}(6)$ & $22(1)$ & $20(1)$ & $18(1)$ & $-3(1)$ & $-1(1)$ & $-2(1)$ \\
$\mathrm{C}(7)$ & $23(1)$ & $25(1)$ & $18(1)$ & $-2(1)$ & $3(1)$ & $-4(1)$ \\
$\mathrm{C}(8)$ & $21(1)$ & $31(1)$ & $18(1)$ & $3(1)$ & $3(1)$ & $-2(1)$ \\
$\mathrm{C}(9)$ & $23(1)$ & $44(1)$ & $26(1)$ & $0(1)$ & $3(1)$ & $4(1)$ \\
$\mathrm{C}(10)$ & $22(1)$ & $37(1)$ & $24(1)$ & $-4(1)$ & $-4(1)$ & $-4(1)$ \\
$\mathrm{C}(11)$ & $31(1)$ & $34(1)$ & $34(1)$ & $1(1)$ & $-5(1)$ & $-6(1)$ \\
$\mathrm{C}(12)$ & $24(1)$ & $40(1)$ & $33(1)$ & $-1(1)$ & $4(1)$ & $2(1)$ \\
$\mathrm{C}(13)$ & $38(1)$ & $43(1)$ & $63(1)$ & $-15(1)$ & $1(1)$ & $5(1)$ \\
$\mathrm{O}(1)$ & $20(1)$ & $38(1)$ & $20(1)$ & $5(1)$ & $0(1)$ & $1(1)$ \\
$\mathrm{O}(2)$ & $29(1)$ & $44(1)$ & $18(1)$ & $6(1)$ & $1(1)$ & $-1(1)$ \\
$\mathrm{O}(3)$ & $36(1)$ & $35(1)$ & $36(1)$ & $-9(1)$ & $-17(1)$ & $10(1)$ \\
$\mathrm{O}(4)$ & $30(1)$ & $20(1)$ & $31(1)$ & $-2(1)$ & $-4(1)$ & $-3(1)$ \\
\hline
\end{tabular}

Table 7: Hydrogen coordinates $\left(\mathrm{x} 10^{4}\right)$ and isotropic displacement parameters $\left(\AA^{2} \times 10^{3}\right)$.

\begin{tabular}{lrrrr}
\hline & $x$ & $y$ & $z$ & $U(e q)$ \\
\hline$H(3 A)$ & -300 & 636 & 3946 & 35 \\
$H(3 B)$ & -1942 & 862 & 4448 & 35 \\
$H(4 A)$ & -1371 & 995 & 2331 & 32 \\
$H(4 B)$ & -2835 & 1566 & 2877 & 32 \\
H(5) & -600 & 2783 & 1920 & 28 \\
H(7A) & 1986 & 3074 & 2651 & 26 \\
H(7B) & 1466 & 1781 & 2949 & 26 \\
H(9A) & -2218 & 2497 & 5706 & 47 \\
H(9B) & -2608 & 3191 & 4613 & 47
\end{tabular}




\begin{tabular}{lccll}
$\mathrm{H}(9 \mathrm{C})$ & -1406 & 3713 & 5457 & 47 \\
$\mathrm{H}(10 \mathrm{~A})$ & 2264 & 4160 & 4841 & 33 \\
$\mathrm{H}(10 \mathrm{~B})$ & 3845 & 3643 & 5240 & 33 \\
$\mathrm{H}(11 \mathrm{~A})$ & 4961 & 4162 & 3602 & 50 \\
$\mathrm{H}(11 \mathrm{~B})$ & 4153 & 5289 & 4095 & 50 \\
$\mathrm{H}(11 \mathrm{C})$ & 3372 & 4582 & 3122 & 50 \\
$\mathrm{H}(12 \mathrm{~A})$ & 4594 & 2195 & 3239 & 38 \\
$\mathrm{H}(12 B)$ & 4857 & 1928 & 4497 & 38 \\
$\mathrm{H}(13 \mathrm{~A})$ & 3366 & 218 & 4289 & 72 \\
$\mathrm{H}(13 \mathrm{~B})$ & 4882 & 191 & 3596 & 72 \\
$\mathrm{H}(13 \mathrm{C})$ & 3307 & 468 & 3011 & 72 \\
$\mathrm{H}(3 \mathrm{O})$ & $-2840(20)$ & $3519(19)$ & $2227(18)$ & $63(8)$ \\
$\mathrm{H}(4 \mathrm{O})$ & $-730(30)$ & $4510(20)$ & $3581(19)$ & $85(9)$ \\
\hline
\end{tabular}

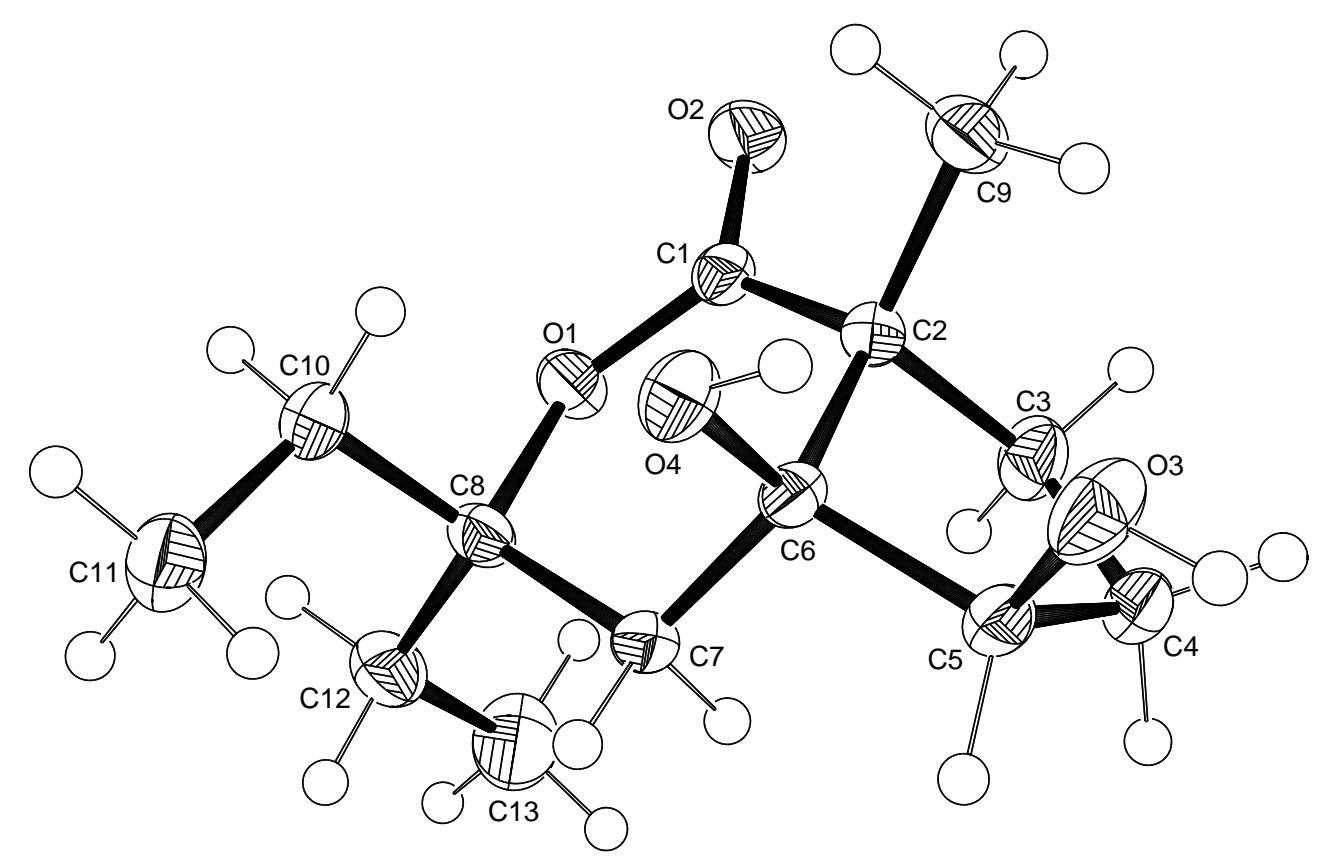

Figure 1: Ortep plot of compound $\mathbf{7 b}$ (thermal ellipsoids are set at the 50\% probability level) 


\section{Compound 20a}

\section{CCDC 1480545}

Table 8: Crystal data and structure refinement for compound 20a.

Empirical formula

Formula weight

Temperature

Wavelength

Crystal system

Space group

Unit cell dimensions

Volume

$\mathrm{Z}$

Density (calculated)

Absorption coefficient

$\mathrm{F}(000)$

Crystal size

Theta range for data collection

Index ranges

Reflections collected

Independent reflections

Completeness to theta $=27.00^{\circ}$

Max. and min. transmission

Refinement method

Data / restraints / parameters

Goodness-of-fit on $\mathrm{F}^{2}$

Final $\mathrm{R}$ indices [I $>2 \operatorname{sigma}(\mathrm{I})]$

$\mathrm{R}$ indices (all data)

Largest diff. peak and hole
$\mathrm{C}_{17} \mathrm{H}_{26} \mathrm{O}_{5}$

$310.38 \mathrm{~g} / \mathrm{mol}$

173(2) K

$0.71073 \AA$

Monoclinic

$P 21 /$ n (14)

$\mathrm{a}=10.8737(8) \AA$

$\alpha=90^{\circ}$.

$\mathrm{b}=11.5374(7) \AA$

$\beta=91.379(7)^{\circ}$.

$\mathrm{c}=12.6318(9) \AA$

$\gamma=90^{\circ}$.
4

$1.301 \mathrm{Mg} / \mathrm{m}^{3}$

$0.094 \mathrm{~mm}^{-1}$

672

$0.40 \times 0.40 \times 0.30 \mathrm{~mm}^{3}$

2.39 to $27.00^{\circ}$.

$-11<=\mathrm{h}<=13,-14<=\mathrm{k}<=14,-16<=\mathrm{l}<=16$

11788

$3431[\mathrm{R}(\mathrm{int})=0.0352]$

$99.1 \%$

0.9722 and 0.9632

Full-matrix least-squares on $\mathrm{F}^{2}$

3431 / 0 / 203

1.004

$\mathrm{R} 1=0.0379, \mathrm{wR} 2=0.0715$

$\mathrm{R} 1=0.0600, \mathrm{wR} 2=0.0739$

0.231 and -0.220 e. $\AA^{-3}$ 
Table 9: Atomic coordinates (x 104) and equivalent isotropic displacement parameters $\left(\AA^{2} \mathrm{x}\right.$ $10^{3}$ ) for compound 20a. U(eq) is defined as one third of the trace of the orthogonalized $U^{i j}$ tensor.

\begin{tabular}{lrrrl}
\hline & $\mathrm{x}$ & $\mathrm{y}$ & $\mathrm{z}$ & $\mathrm{U}(\mathrm{eq})$ \\
\hline $\mathrm{C}(1)$ & & & & \\
$\mathrm{C}(2)$ & $9603(1)$ & $4435(1)$ & $2978(1)$ & $16(1)$ \\
$\mathrm{C}(3)$ & $10148(1)$ & $3568(1)$ & $3767(1)$ & $17(1)$ \\
$\mathrm{C}(4)$ & $9255(1)$ & $2686(1)$ & $4196(1)$ & $20(1)$ \\
$\mathrm{C}(5)$ & $8380(1)$ & $3174(1)$ & $4995(1)$ & $33(1)$ \\
$\mathrm{C}(6)$ & $9955(1)$ & $1658(1)$ & $4657(1)$ & $30(1)$ \\
$\mathrm{C}(7)$ & $8220(1)$ & $2710(1)$ & $2419(1)$ & $19(1)$ \\
$\mathrm{C}(8)$ & $8927(1)$ & $3770(1)$ & $2071(1)$ & $17(1)$ \\
$\mathrm{C}(9)$ & $8062(1)$ & $4551(1)$ & $1420(1)$ & $26(1)$ \\
$\mathrm{C}(10)$ & $10006(1)$ & $3344(1)$ & $1394(1)$ & $25(1)$ \\
$\mathrm{C}(11)$ & $11052(1)$ & $4229(1)$ & $1543(1)$ & $25(1)$ \\
$\mathrm{C}(12)$ & $10683(1)$ & $5031(1)$ & $2439(1)$ & $17(1)$ \\
$\mathrm{C}(13)$ & $11109(1)$ & $6944(1)$ & $1836(1)$ & $20(1)$ \\
$\mathrm{C}(14)$ & $10518(1)$ & $8051(1)$ & $1466(1)$ & $17(1)$ \\
$\mathrm{C}(15)$ & $11357(1)$ & $8856(1)$ & $847(1)$ & $22(1)$ \\
$\mathrm{C}(16)$ & $10961(1)$ & $10099(1)$ & $1141(1)$ & $22(1)$ \\
$\mathrm{C}(17)$ & $9880(1)$ & $9960(1)$ & $1876(1)$ & $26(1)$ \\
$\mathrm{O}(1)$ & $10117(1)$ & $8790(1)$ & $2402(1)$ & $25(1)$ \\
$\mathrm{O}(2)$ & $8483(1)$ & $2188(1)$ & $3338(1)$ & $24(1)$ \\
$\mathrm{O}(3)$ & $7445(1)$ & $2262(1)$ & $1851(1)$ & $29(1)$ \\
$\mathrm{O}(4)$ & $8856(1)$ & $5195(1)$ & $3556(1)$ & $21(1)$ \\
$\mathrm{O}(5)$ & $10250(1)$ & $6137(1)$ & $2032(1)$ & $21(1)$ \\
\hline & $12192(1)$ & $6783(1)$ & $1985(1)$ & $33(1)$ \\
\hline
\end{tabular}

Table 10: Bond lengths $[\AA]$ and angles $\left[{ }^{\circ}\right]$.

\begin{tabular}{lc}
\hline $\mathrm{C}(1)-\mathrm{O}(3)$ & $1.4112(15)$ \\
$\mathrm{C}(1)-\mathrm{C}(2)$ & $1.5221(16)$ \\
$\mathrm{C}(1)-\mathrm{C}(11)$ & $1.5351(18)$ \\
$\mathrm{C}(1)-\mathrm{C}(7)$ & $1.5496(16)$ \\
$\mathrm{C}(2)-\mathrm{C}(3)$ & $1.5163(18)$ \\
$\mathrm{C}(3)-\mathrm{O}(1)$ & $1.4712(14)$ \\
$\mathrm{C}(3)-\mathrm{C}(4)$ & $1.512(2)$
\end{tabular}




\begin{tabular}{|c|c|}
\hline$C(3)-C(5)$ & $1.5175(17)$ \\
\hline $\mathrm{C}(6)-\mathrm{O}(2)$ & $1.2094(14)$ \\
\hline $\mathrm{C}(6)-\mathrm{O}(1)$ & $1.3331(15)$ \\
\hline$C(6)-C(7)$ & $1.5152(17)$ \\
\hline$C(7)-C(8)$ & $1.5277(16)$ \\
\hline$C(7)-C(9)$ & $1.5487(19)$ \\
\hline $\mathrm{C}(9)-\mathrm{C}(10)$ & $1.5362(18)$ \\
\hline $\mathrm{C}(10)-\mathrm{C}(11)$ & $1.5218(19)$ \\
\hline $\mathrm{C}(11)-\mathrm{O}(4)$ & $1.4502(14)$ \\
\hline $\mathrm{C}(12)-\mathrm{O}(5)$ & $1.2027(15)$ \\
\hline $\mathrm{C}(12)-\mathrm{O}(4)$ & $1.3462(15)$ \\
\hline $\mathrm{C}(12)-\mathrm{C}(13)$ & $1.4985(17)$ \\
\hline $\mathrm{C}(13)-\mathrm{C}(14)$ & $1.5301(18)$ \\
\hline $\mathrm{C}(13)-\mathrm{C}(17)$ & $1.5304(18)$ \\
\hline $\mathrm{C}(14)-\mathrm{C}(15)$ & $1.5445(18)$ \\
\hline$C(15)-C(16)$ & $1.525(2)$ \\
\hline $\mathrm{C}(16)-\mathrm{C}(17)$ & $1.5239(18)$ \\
\hline $\mathrm{O}(3)-\mathrm{C}(1)-\mathrm{C}(2)$ & $106.81(10)$ \\
\hline $\mathrm{O}(3)-\mathrm{C}(1)-\mathrm{C}(11)$ & $114.06(10)$ \\
\hline $\mathrm{C}(2)-\mathrm{C}(1)-\mathrm{C}(11)$ & $107.13(10)$ \\
\hline $\mathrm{O}(3)-\mathrm{C}(1)-\mathrm{C}(7)$ & $114.94(10)$ \\
\hline $\mathrm{C}(2)-\mathrm{C}(1)-\mathrm{C}(7)$ & $109.24(9)$ \\
\hline $\mathrm{C}(11)-\mathrm{C}(1)-\mathrm{C}(7)$ & $104.40(10)$ \\
\hline $\mathrm{C}(3)-\mathrm{C}(2)-\mathrm{C}(1)$ & $115.63(11)$ \\
\hline $\mathrm{O}(1)-\mathrm{C}(3)-\mathrm{C}(4)$ & $106.27(11)$ \\
\hline $\mathrm{O}(1)-\mathrm{C}(3)-\mathrm{C}(2)$ & $110.92(10)$ \\
\hline$C(4)-C(3)-C(2)$ & $114.04(11)$ \\
\hline $\mathrm{O}(1)-\mathrm{C}(3)-\mathrm{C}(5)$ & $104.43(10)$ \\
\hline$C(4)-C(3)-C(5)$ & $110.72(12)$ \\
\hline$C(2)-C(3)-C(5)$ & $109.98(11)$ \\
\hline $\mathrm{O}(2)-\mathrm{C}(6)-\mathrm{O}(1)$ & $117.09(12)$ \\
\hline $\mathrm{O}(2)-\mathrm{C}(6)-\mathrm{C}(7)$ & $121.60(11)$ \\
\hline $\mathrm{O}(1)-\mathrm{C}(6)-\mathrm{C}(7)$ & $121.17(11)$ \\
\hline$C(6)-C(7)-C(8)$ & $108.79(10)$ \\
\hline $\mathrm{C}(6)-\mathrm{C}(7)-\mathrm{C}(9)$ & $107.54(10)$ \\
\hline $\mathrm{C}(8)-\mathrm{C}(7)-\mathrm{C}(9)$ & $110.80(11)$ \\
\hline$C(6)-C(7)-C(1)$ & $114.81(10)$ \\
\hline $\mathrm{C}(8)-\mathrm{C}(7)-\mathrm{C}(1)$ & $112.37(10)$ \\
\hline
\end{tabular}




$\begin{array}{ll}\mathrm{C}(9)-\mathrm{C}(7)-\mathrm{C}(1) & 102.27(10) \\ \mathrm{C}(10)-\mathrm{C}(9)-\mathrm{C}(7) & 106.86(10) \\ \mathrm{C}(11)-\mathrm{C}(10)-\mathrm{C}(9) & 106.76(12) \\ \mathrm{O}(4)-\mathrm{C}(11)-\mathrm{C}(10) & 111.13(10) \\ \mathrm{O}(4)-\mathrm{C}(11)-\mathrm{C}(1) & 107.80(10) \\ \mathrm{C}(10)-\mathrm{C}(11)-\mathrm{C}(1) & 105.96(10) \\ \mathrm{O}(5)-\mathrm{C}(12)-\mathrm{O}(4) & 123.06(12) \\ \mathrm{O}(5)-\mathrm{C}(12)-\mathrm{C}(13) & 126.24(12) \\ \mathrm{O}(4)-\mathrm{C}(12)-\mathrm{C}(13) & 110.64(11) \\ \mathrm{C}(12)-\mathrm{C}(13)-\mathrm{C}(14) & 114.87(11) \\ \mathrm{C}(12)-\mathrm{C}(13)-\mathrm{C}(17) & 111.20(10) \\ \mathrm{C}(14)-\mathrm{C}(13)-\mathrm{C}(17) & 103.91(10) \\ \mathrm{C}(13)-\mathrm{C}(14)-\mathrm{C}(15) & 105.56(11) \\ \mathrm{C}(16)-\mathrm{C}(15)-\mathrm{C}(14) & 105.81(10) \\ \mathrm{C}(17)-\mathrm{C}(16)-\mathrm{C}(15) & 103.50(11) \\ \mathrm{C}(16)-\mathrm{C}(17)-\mathrm{C}(13) & 101.84(10) \\ \mathrm{C}(6)-\mathrm{O}(1)-\mathrm{C}(3) & 124.91(10) \\ \mathrm{C}(12)-\mathrm{O}(4)-\mathrm{C}(11) & 116.94(10)\end{array}$

Table 11: Anisotropic displacement parameters $\left(\AA^{2} \mathrm{x} 10^{3}\right)$ for 2143. The anisotropic displacement factor exponent takes the form: $-2 \pi^{2}\left[h^{2} a^{* 2} U^{11}+\ldots+2 h k a^{*} b^{*} U^{12}\right]$.

\begin{tabular}{lcccccc}
\hline & $\mathrm{U}^{11}$ & $\mathrm{U}^{22}$ & $\mathrm{U}^{33}$ & $\mathrm{U}^{23}$ & $\mathrm{U}^{13}$ & $\mathrm{U}^{12}$ \\
\hline $\mathrm{C}(1)$ & $16(1)$ & $12(1)$ & $19(1)$ & $-2(1)$ & $1(1)$ & $1(1)$ \\
$\mathrm{C}(2)$ & $19(1)$ & $16(1)$ & $17(1)$ & $-1(1)$ & $0(1)$ & $2(1)$ \\
$\mathrm{C}(3)$ & $27(1)$ & $17(1)$ & $17(1)$ & $-1(1)$ & $0(1)$ & $0(1)$ \\
$\mathrm{C}(4)$ & $39(1)$ & $28(1)$ & $32(1)$ & $1(1)$ & $15(1)$ & $-2(1)$ \\
$\mathrm{C}(5)$ & $42(1)$ & $23(1)$ & $26(1)$ & $6(1)$ & $-1(1)$ & $4(1)$ \\
$\mathrm{C}(6)$ & $19(1)$ & $15(1)$ & $23(1)$ & $-1(1)$ & $2(1)$ & $2(1)$ \\
$\mathrm{C}(7)$ & $20(1)$ & $15(1)$ & $16(1)$ & $-1(1)$ & $-1(1)$ & $-1(1)$ \\
$\mathrm{C}(8)$ & $28(1)$ & $23(1)$ & $25(1)$ & $4(1)$ & $-9(1)$ & $-6(1)$ \\
$\mathrm{C}(9)$ & $32(1)$ & $22(1)$ & $23(1)$ & $-5(1)$ & $7(1)$ & $-3(1)$ \\
$\mathrm{C}(10)$ & $26(1)$ & $23(1)$ & $27(1)$ & $1(1)$ & $8(1)$ & $-1(1)$ \\
$\mathrm{C}(11)$ & $16(1)$ & $13(1)$ & $23(1)$ & $4(1)$ & $-2(1)$ & $1(1)$ \\
$\mathrm{C}(12)$ & $21(1)$ & $18(1)$ & $20(1)$ & $0(1)$ & $1(1)$ & $-3(1)$ \\
$\mathrm{C}(13)$ & $16(1)$ & $16(1)$ & $18(1)$ & $2(1)$ & $-2(1)$ & $-1(1)$ \\
$\mathrm{C}(14)$ & $20(1)$ & $20(1)$ & $24(1)$ & $6(1)$ & $3(1)$ & $1(1)$
\end{tabular}




\begin{tabular}{lllllll}
$\mathrm{C}(15)$ & $22(1)$ & $17(1)$ & $25(1)$ & $2(1)$ & $-3(1)$ & $-3(1)$ \\
$\mathrm{C}(16)$ & $33(1)$ & $19(1)$ & $26(1)$ & $0(1)$ & $3(1)$ & $4(1)$ \\
$\mathrm{C}(17)$ & $28(1)$ & $25(1)$ & $22(1)$ & $4(1)$ & $5(1)$ & $4(1)$ \\
$\mathrm{O}(1)$ & $32(1)$ & $16(1)$ & $25(1)$ & $4(1)$ & $-3(1)$ & $-7(1)$ \\
$\mathrm{O}(2)$ & $29(1)$ & $22(1)$ & $36(1)$ & $-1(1)$ & $-8(1)$ & $-10(1)$ \\
$\mathrm{O}(3)$ & $26(1)$ & $14(1)$ & $21(1)$ & $-1(1)$ & $3(1)$ & $7(1)$ \\
$\mathrm{O}(4)$ & $18(1)$ & $14(1)$ & $31(1)$ & $5(1)$ & $-3(1)$ & $-2(1)$ \\
$\mathrm{O}(5)$ & $16(1)$ & $27(1)$ & $56(1)$ & $17(1)$ & $-1(1)$ & $-2(1)$ \\
\hline
\end{tabular}

Table 12: Hydrogen coordinates (x $\left.10^{4}\right)$ and isotropic displacement parameters $\left(\AA^{2} \times 10^{3}\right)$ for compound 20a.

\begin{tabular}{|c|c|c|c|c|}
\hline & $\mathrm{x}$ & $\mathrm{y}$ & $\mathrm{z}$ & $\mathrm{U}(\mathrm{eq})$ \\
\hline $\mathrm{H}(2 \mathrm{~A})$ & 10822 & 3146 & 3421 & 21 \\
\hline $\mathrm{H}(2 \mathrm{~B})$ & 10516 & 4003 & 4371 & 21 \\
\hline $\mathrm{H}(4 \mathrm{~A})$ & 7910 & 3814 & 4673 & 49 \\
\hline $\mathrm{H}(4 \mathrm{~B})$ & 8849 & 3460 & 5613 & 49 \\
\hline $\mathrm{H}(4 \mathrm{C})$ & 7812 & 2565 & 5216 & 49 \\
\hline $\mathrm{H}(5 \mathrm{~A})$ & 9371 & 1073 & 4897 & 45 \\
\hline $\mathrm{H}(5 \mathrm{~B})$ & 10472 & 1915 & 5258 & 45 \\
\hline $\mathrm{H}(5 \mathrm{C})$ & 10475 & 1322 & 4113 & 45 \\
\hline $\mathrm{H}(8 \mathrm{~A})$ & 7690 & 4104 & 835 & 38 \\
\hline $\mathrm{H}(8 \mathrm{~B})$ & 8527 & 5202 & 1135 & 38 \\
\hline $\mathrm{H}(8 \mathrm{C})$ & 7413 & 4846 & 1873 & 38 \\
\hline $\mathrm{H}(9 \mathrm{~A})$ & 10282 & 2567 & 1631 & 31 \\
\hline $\mathrm{H}(9 \mathrm{~B})$ & 9747 & 3297 & 638 & 31 \\
\hline $\mathrm{H}(10 \mathrm{~A})$ & 11834 & 3830 & 1728 & 30 \\
\hline $\mathrm{H}(10 \mathrm{~B})$ & 11163 & 4677 & 884 & 30 \\
\hline $\mathrm{H}(11)$ & 11387 & 5144 & 2953 & 21 \\
\hline $\mathrm{H}(13)$ & 9778 & 7860 & 1014 & 20 \\
\hline $\mathrm{H}(14 \mathrm{~A})$ & 11251 & 8724 & 76 & 26 \\
\hline $\mathrm{H}(14 \mathrm{~B})$ & 12230 & 8723 & 1052 & 26 \\
\hline $\mathrm{H}(15 \mathrm{~A})$ & 11646 & 10516 & 1504 & 26 \\
\hline $\mathrm{H}(15 \mathrm{~B})$ & 10710 & 10538 & 498 & 26 \\
\hline $\mathrm{H}(16 \mathrm{~A})$ & 9867 & 10590 & 2407 & 31 \\
\hline $\mathrm{H}(16 \mathrm{~B})$ & 9088 & 9958 & 1471 & 31 \\
\hline
\end{tabular}




\begin{tabular}{lrlll}
$\mathrm{H}(17 \mathrm{~A})$ & 9362 & 8478 & 2720 & 30 \\
$\mathrm{H}(17 \mathrm{~B})$ & 10776 & 8844 & 2955 & 30 \\
$\mathrm{H}(3)$ & 8644 & 5757 & 3171 & 31 \\
\hline
\end{tabular}

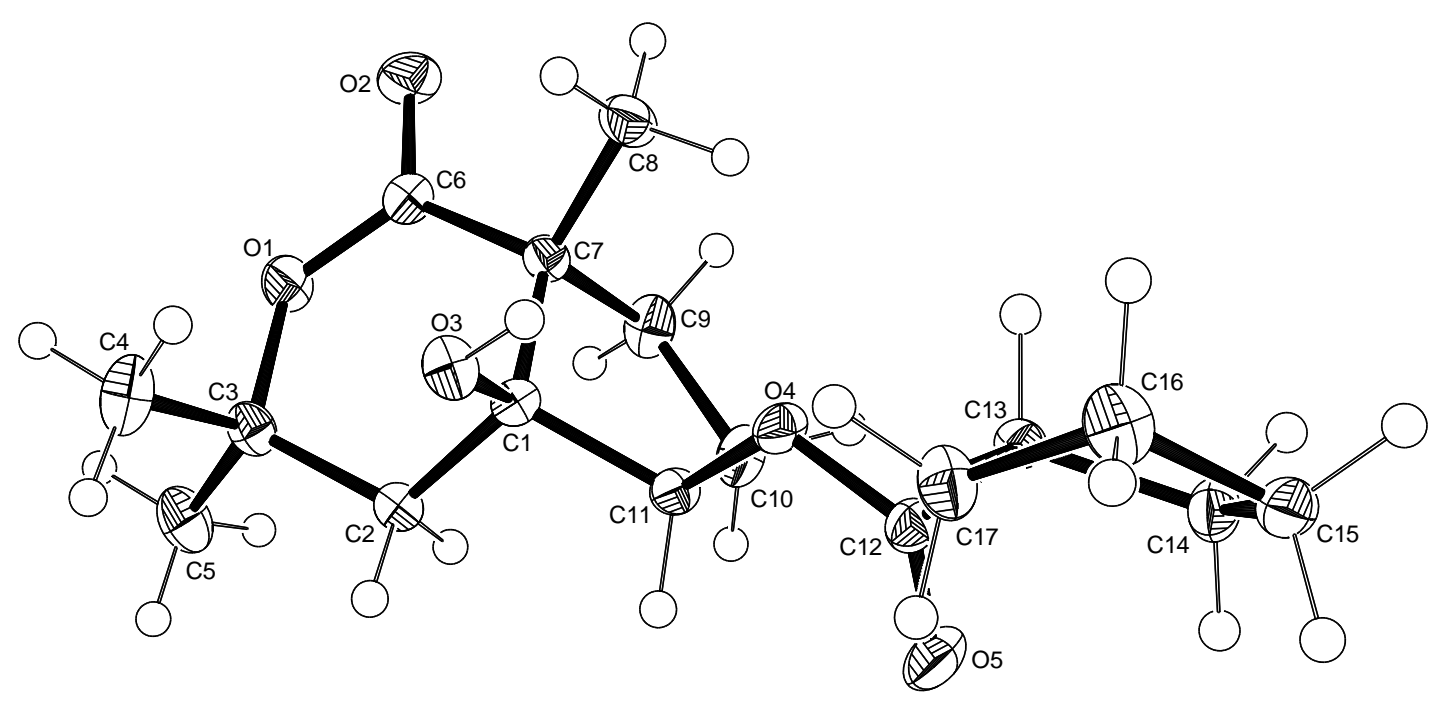

Figure 2: Ortep plot of compound 20a (thermal ellipsoids are set at the 50\% probability level). 


\section{Compound 211}

\section{CCDC 1480546}

Table 13: Crystal data and structure refinement for compound 211.

Empirical formula

Formula weight

Temperature

Wavelength

Crystal system

Space group

Unit cell dimensions

Volume

$\mathrm{Z}$

Density (calculated)

Absorption coefficient

$\mathrm{F}(000)$

Crystal size

Theta range for data collection

Index ranges

Reflections collected

Independent reflections

Completeness to theta $=26.00^{\circ}$

Max. and min. transmission

Refinement method

Data / restraints / parameters

Goodness-of-fit on $\mathrm{F}^{2}$

Final R indices [I>2sigma(I)]

$\mathrm{R}$ indices (all data)

Largest diff. peak and hole
$\mathrm{C}_{21} \mathrm{H}_{17} \mathrm{Cl}_{2} \mathrm{FO}_{5}$

$439.25 \mathrm{~g} / \mathrm{mol}$

173(2) K

$0.71073 \AA$

Triclinic

P-1

$\mathrm{a}=6.6638(3) \AA$

$\alpha=83.956(4)^{\circ}$.

$\mathrm{b}=6.7128(4) \AA$

$\beta=87.265(4)^{\circ}$.

$\mathrm{c}=23.7243(11) \AA$

$\gamma=61.768(5)^{\circ}$.
929.81(8) $\AA^{3}$

2

$1.569 \mathrm{Mg} / \mathrm{m}^{3}$

$0.392 \mathrm{~mm}^{-1}$

452

$0.30 \times 0.20 \times 0.10 \mathrm{~mm}^{3}$

2.59 to $26.00^{\circ}$.

$-8<=\mathrm{h}<=8,-8<=\mathrm{k}<=8,-29<=\mathrm{l}<=29$

9916

$3660[\mathrm{R}(\mathrm{int})=0.0253]$

$99.8 \%$

0.9619 and 0.8915

Full-matrix least-squares on $\mathrm{F}^{2}$

$3660 / 0 / 263$

1.004

$\mathrm{R} 1=0.0407, \mathrm{wR} 2=0.1189$

$\mathrm{R} 1=0.0458, \mathrm{wR} 2=0.1233$

0.659 and -0.390 e. $\AA^{-3}$ 


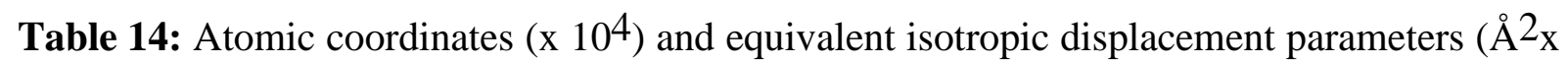
$10^{3}$ ) for compound 211. U(eq) is defined as one third of the trace of the orthogonalized Uij tensor.

\begin{tabular}{|c|c|c|c|c|}
\hline & $\mathrm{x}$ & $\mathrm{y}$ & $\mathrm{z}$ & $\mathrm{U}(\mathrm{eq})$ \\
\hline $\mathrm{C}(1)$ & $13508(4)$ & $10596(4)$ & $6045(1)$ & $21(1)$ \\
\hline $\mathrm{C}(2)$ & $15462(4)$ & $10240(4)$ & $5743(1)$ & 19(1) \\
\hline$C(3)$ & $17223(4)$ & $8056(4)$ & $5715(1)$ & 21(1) \\
\hline $\mathrm{C}(4)$ & $17041(4)$ & $6222(4)$ & 5981(1) & $23(1)$ \\
\hline $\mathrm{C}(5)$ & $15110(4)$ & $6562(4)$ & $6286(1)$ & $22(1)$ \\
\hline $\mathrm{C}(6)$ & $13326(4)$ & $8749(4)$ & $6319(1)$ & $20(1)$ \\
\hline $\mathrm{C}(7)$ & 11141(4) & 9180(4) & 6613(1) & $20(1)$ \\
\hline $\mathrm{C}(8)$ & $9259(3)$ & 7389(3) & $7150(1)$ & $18(1)$ \\
\hline$C(9)$ & $9697(4)$ & 4946(4) & 7311(1) & $23(1)$ \\
\hline$C(10)$ & 9703(4) & 4634(3) & $7955(1)$ & $21(1)$ \\
\hline $\mathrm{C}(11)$ & $8031(3)$ & 6994(3) & $8125(1)$ & $17(1)$ \\
\hline$C(12)$ & $8435(3)$ & $8685(3)$ & 7699(1) & $16(1)$ \\
\hline $\mathrm{C}(13)$ & 6065(3) & 10703(4) & 7618(1) & $20(1)$ \\
\hline$C(14)$ & $5579(3)$ & 7641(4) & 7983(1) & $19(1)$ \\
\hline$C(15)$ & $8257(4)$ & $7186(4)$ & $8756(1)$ & $21(1)$ \\
\hline$C(16)$ & $6560(4)$ & $9336(4)$ & $9005(1)$ & $21(1)$ \\
\hline $\mathrm{C}(17)$ & 7148(4) & 11011(4) & $9089(1)$ & $29(1)$ \\
\hline$C(18)$ & $5665(5)$ & $12937(4)$ & $9343(1)$ & $34(1)$ \\
\hline$C(19)$ & $3577(4)$ & $13174(4)$ & $9509(1)$ & $30(1)$ \\
\hline$C(20)$ & 2893(4) & $11589(4)$ & $9433(1)$ & $28(1)$ \\
\hline $\mathrm{C}(21)$ & $4407(4)$ & $9659(4)$ & 9179(1) & $25(1)$ \\
\hline $\mathrm{Cl}(1)$ & $15642(1)$ & $12550(1)$ & $5401(1)$ & $26(1)$ \\
\hline $\mathrm{Cl}(2)$ & 19689(1) & $7596(1)$ & $5346(1)$ & $30(1)$ \\
\hline $\mathrm{F}$ & $2128(3)$ & $15054(3)$ & $9769(1)$ & $43(1)$ \\
\hline $\mathrm{O}(1)$ & 9392(3) & 10944(3) & $6560(1)$ & $25(1)$ \\
\hline $\mathrm{O}(2)$ & $11346(2)$ & $7319(2)$ & 6930(1) & $20(1)$ \\
\hline $\mathrm{O}(3)$ & 9893(2) & $9450(3)$ & $7880(1)$ & $21(1)$ \\
\hline $\mathrm{O}(4)$ & $4533(2)$ & $9719(3)$ & $7699(1)$ & $22(1)$ \\
\hline $\mathrm{O}(5)$ & $4597(3)$ & $6538(3)$ & $8093(1)$ & $26(1)$ \\
\hline
\end{tabular}


Table 15: Bond lengths $[\AA]$ and angles $\left[{ }^{\circ}\right]$.

\begin{tabular}{|c|c|}
\hline$C(1)-C(2)$ & $1.385(3)$ \\
\hline$C(1)-C(6)$ & $1.393(3)$ \\
\hline$C(2)-C(3)$ & $1.384(3)$ \\
\hline $\mathrm{C}(2)-\mathrm{Cl}(1)$ & $1.725(2)$ \\
\hline$C(3)-C(4)$ & $1.378(3)$ \\
\hline $\mathrm{C}(3)-\mathrm{Cl}(2)$ & $1.733(2)$ \\
\hline$C(4)-C(5)$ & $1.378(3)$ \\
\hline$C(5)-C(6)$ & $1.392(3)$ \\
\hline$C(6)-C(7)$ & $1.496(3)$ \\
\hline $\mathrm{C}(7)-\mathrm{O}(1)$ & $1.206(3)$ \\
\hline $\mathrm{C}(7)-\mathrm{O}(2)$ & $1.339(3)$ \\
\hline $\mathrm{C}(8)-\mathrm{O}(2)$ & $1.444(2)$ \\
\hline $\mathrm{C}(8)-\mathrm{C}(9)$ & $1.531(3)$ \\
\hline $\mathrm{C}(8)-\mathrm{C}(12)$ & $1.573(3)$ \\
\hline $\mathrm{C}(9)-\mathrm{C}(10)$ & $1.521(3)$ \\
\hline $\mathrm{C}(10)-\mathrm{C}(11)$ & $1.529(3)$ \\
\hline $\mathrm{C}(11)-\mathrm{C}(14)$ & $1.524(3)$ \\
\hline$C(11)-C(15)$ & $1.536(3)$ \\
\hline $\mathrm{C}(11)-\mathrm{C}(12)$ & $1.550(3)$ \\
\hline $\mathrm{C}(12)-\mathrm{O}(3)$ & $1.397(2)$ \\
\hline $\mathrm{C}(12)-\mathrm{C}(13)$ & $1.522(3)$ \\
\hline $\mathrm{C}(13)-\mathrm{O}(4)$ & $1.452(3)$ \\
\hline $\mathrm{C}(14)-\mathrm{O}(5)$ & $1.203(3)$ \\
\hline $\mathrm{C}(14)-\mathrm{O}(4)$ & $1.346(3)$ \\
\hline$C(15)-C(16)$ & $1.511(3)$ \\
\hline$C(16)-C(17)$ & $1.389(3)$ \\
\hline$C(16)-C(21)$ & $1.394(3)$ \\
\hline $\mathrm{C}(17)-\mathrm{C}(18)$ & $1.382(4)$ \\
\hline $\mathrm{C}(18)-\mathrm{C}(19)$ & $1.366(4)$ \\
\hline$C(19)-F$ & $1.363(3)$ \\
\hline $\mathrm{C}(19)-\mathrm{C}(20)$ & $1.371(4)$ \\
\hline $\mathrm{C}(20)-\mathrm{C}(21)$ & $1.389(3)$ \\
\hline$C(2)-C(1)-C(6)$ & $119.70(19)$ \\
\hline$C(3)-C(2)-C(1)$ & 119.94(19) \\
\hline $\mathrm{C}(3)-\mathrm{C}(2)-\mathrm{Cl}(1)$ & $121.13(17)$ \\
\hline
\end{tabular}




\begin{tabular}{|c|c|}
\hline $\mathrm{C}(1)-\mathrm{C}(2)-\mathrm{Cl}(1)$ & $118.93(16)$ \\
\hline$C(4)-C(3)-C(2)$ & $120.6(2)$ \\
\hline $\mathrm{C}(4)-\mathrm{C}(3)-\mathrm{Cl}(2)$ & $119.16(17)$ \\
\hline $\mathrm{C}(2)-\mathrm{C}(3)-\mathrm{Cl}(2)$ & $120.29(17)$ \\
\hline$C(3)-C(4)-C(5)$ & $119.9(2)$ \\
\hline$C(4)-C(5)-C(6)$ & $120.3(2)$ \\
\hline$C(5)-C(6)-C(1)$ & $119.6(2)$ \\
\hline$C(5)-C(6)-C(7)$ & $121.94(19)$ \\
\hline$C(1)-C(6)-C(7)$ & $118.33(19)$ \\
\hline $\mathrm{O}(1)-\mathrm{C}(7)-\mathrm{O}(2)$ & $124.0(2)$ \\
\hline $\mathrm{O}(1)-\mathrm{C}(7)-\mathrm{C}(6)$ & $124.7(2)$ \\
\hline $\mathrm{O}(2)-\mathrm{C}(7)-\mathrm{C}(6)$ & $111.24(18)$ \\
\hline $\mathrm{O}(2)-\mathrm{C}(8)-\mathrm{C}(9)$ & $108.32(16)$ \\
\hline $\mathrm{O}(2)-\mathrm{C}(8)-\mathrm{C}(12)$ & $112.10(16)$ \\
\hline $\mathrm{C}(9)-\mathrm{C}(8)-\mathrm{C}(12)$ & $107.55(17)$ \\
\hline $\mathrm{C}(10)-\mathrm{C}(9)-\mathrm{C}(8)$ & $106.05(17)$ \\
\hline $\mathrm{C}(9)-\mathrm{C}(10)-\mathrm{C}(11)$ & $103.90(17)$ \\
\hline $\mathrm{C}(14)-\mathrm{C}(11)-\mathrm{C}(10)$ & $111.89(17)$ \\
\hline$C(14)-C(11)-C(15)$ & $110.45(17)$ \\
\hline$C(10)-C(11)-C(15)$ & $111.58(17)$ \\
\hline $\mathrm{C}(14)-\mathrm{C}(11)-\mathrm{C}(12)$ & $100.74(16)$ \\
\hline$C(10)-C(11)-C(12)$ & $105.50(17)$ \\
\hline $\mathrm{C}(15)-\mathrm{C}(11)-\mathrm{C}(12)$ & $116.19(17)$ \\
\hline $\mathrm{O}(3)-\mathrm{C}(12)-\mathrm{C}(13)$ & $108.46(16)$ \\
\hline $\mathrm{O}(3)-\mathrm{C}(12)-\mathrm{C}(11)$ & $116.15(16)$ \\
\hline $\mathrm{C}(13)-\mathrm{C}(12)-\mathrm{C}(11)$ & $103.21(16)$ \\
\hline $\mathrm{O}(3)-\mathrm{C}(12)-\mathrm{C}(8)$ & $114.12(16)$ \\
\hline $\mathrm{C}(13)-\mathrm{C}(12)-\mathrm{C}(8)$ & $111.23(17)$ \\
\hline $\mathrm{C}(11)-\mathrm{C}(12)-\mathrm{C}(8)$ & $103.13(16)$ \\
\hline $\mathrm{O}(4)-\mathrm{C}(13)-\mathrm{C}(12)$ & $104.55(16)$ \\
\hline $\mathrm{O}(5)-\mathrm{C}(14)-\mathrm{O}(4)$ & $121.12(19)$ \\
\hline $\mathrm{O}(5)-\mathrm{C}(14)-\mathrm{C}(11)$ & $127.90(19)$ \\
\hline $\mathrm{O}(4)-\mathrm{C}(14)-\mathrm{C}(11)$ & $110.98(17)$ \\
\hline$C(16)-C(15)-C(11)$ & $118.09(17)$ \\
\hline$C(17)-C(16)-C(21)$ & $118.1(2)$ \\
\hline$C(17)-C(16)-C(15)$ & $120.5(2)$ \\
\hline$C(21)-C(16)-C(15)$ & $121.4(2)$ \\
\hline$C(18)-C(17)-C(16)$ & $121.4(2)$ \\
\hline$C(19)-C(18)-C(17)$ & $118.4(2)$ \\
\hline
\end{tabular}




\begin{tabular}{lc}
$\mathrm{F}-\mathrm{C}(19)-\mathrm{C}(18)$ & $118.4(2)$ \\
$\mathrm{F}-\mathrm{C}(19)-\mathrm{C}(20)$ & $118.7(2)$ \\
$\mathrm{C}(18)-\mathrm{C}(19)-\mathrm{C}(20)$ & $122.9(2)$ \\
$\mathrm{C}(19)-\mathrm{C}(20)-\mathrm{C}(21)$ & $118.1(2)$ \\
$\mathrm{C}(20)-\mathrm{C}(21)-\mathrm{C}(16)$ & $121.2(2)$ \\
$\mathrm{C}(7)-\mathrm{O}(2)-\mathrm{C}(8)$ & $116.29(16)$ \\
$\mathrm{C}(14)-\mathrm{O}(4)-\mathrm{C}(13)$ & $110.78(15)$ \\
\hline
\end{tabular}

Table 16: Anisotropic displacement parameters $\left(\AA^{2} \times 10^{3}\right)$ for compound 211. The anisotropic displacement factor exponent takes the form: $-2 \pi^{2}\left[h^{2} a^{*} U^{11}+\ldots+2 h k a^{*} b^{*} U^{12}\right]$.

\begin{tabular}{|c|c|c|c|c|c|c|}
\hline & $\mathrm{U}^{11}$ & $\mathrm{U}^{22}$ & $\mathrm{U}^{33}$ & $\mathrm{U}^{23}$ & $\mathrm{U}^{13}$ & $\mathrm{U}^{12}$ \\
\hline $\mathrm{C}(1)$ & 21(1) & $20(1)$ & 21(1) & $-3(1)$ & $-2(1)$ & $-8(1)$ \\
\hline$C(2)$ & $24(1)$ & 20(1) & $16(1)$ & $1(1)$ & $-2(1)$ & $-13(1)$ \\
\hline$C(3)$ & $20(1)$ & $24(1)$ & $20(1)$ & $-5(1)$ & $1(1)$ & $-11(1)$ \\
\hline $\mathrm{C}(4)$ & $22(1)$ & 19(1) & $24(1)$ & $-3(1)$ & $1(1)$ & $-9(1)$ \\
\hline$C(5)$ & $25(1)$ & $20(1)$ & $22(1)$ & $-1(1)$ & $-1(1)$ & $-12(1)$ \\
\hline$C(6)$ & 21(1) & $23(1)$ & $17(1)$ & $-2(1)$ & $0(1)$ & $-11(1)$ \\
\hline$C(7)$ & $23(1)$ & 21(1) & $18(1)$ & $-2(1)$ & $0(1)$ & $-12(1)$ \\
\hline $\mathrm{C}(8)$ & $17(1)$ & 19(1) & $20(1)$ & $-2(1)$ & $2(1)$ & $-9(1)$ \\
\hline $\mathrm{C}(9)$ & $25(1)$ & 19(1) & $27(1)$ & $-3(1)$ & 1(1) & $-12(1)$ \\
\hline$C(10)$ & $19(1)$ & $16(1)$ & $26(1)$ & $1(1)$ & $-2(1)$ & $-7(1)$ \\
\hline $\mathrm{C}(11)$ & $13(1)$ & $18(1)$ & $20(1)$ & $0(1)$ & $-1(1)$ & $-9(1)$ \\
\hline $\mathrm{C}(12)$ & $15(1)$ & $17(1)$ & $18(1)$ & $-1(1)$ & $-1(1)$ & $-10(1)$ \\
\hline $\mathrm{C}(13)$ & $17(1)$ & $17(1)$ & $26(1)$ & $0(1)$ & 1(1) & $-8(1)$ \\
\hline$C(14)$ & $16(1)$ & $22(1)$ & $20(1)$ & $-1(1)$ & $-1(1)$ & $-10(1)$ \\
\hline$C(15)$ & 19(1) & $24(1)$ & 19(1) & 2(1) & $-2(1)$ & $-10(1)$ \\
\hline$C(16)$ & 24(1) & $24(1)$ & $15(1)$ & 2(1) & $-2(1)$ & $-12(1)$ \\
\hline $\mathrm{C}(17)$ & $36(1)$ & $39(1)$ & 21(1) & $-4(1)$ & $5(1)$ & $-25(1)$ \\
\hline$C(18)$ & $54(2)$ & $34(1)$ & $24(1)$ & $-6(1)$ & $4(1)$ & $-29(1)$ \\
\hline $\mathrm{C}(19)$ & $39(1)$ & $24(1)$ & $18(1)$ & $-4(1)$ & $-3(1)$ & $-7(1)$ \\
\hline$C(20)$ & $22(1)$ & $34(1)$ & $23(1)$ & $-3(1)$ & $-2(1)$ & $-9(1)$ \\
\hline $\mathrm{C}(21)$ & $26(1)$ & $26(1)$ & $24(1)$ & $-1(1)$ & $-3(1)$ & $-13(1)$ \\
\hline $\mathrm{Cl}(1)$ & $29(1)$ & $22(1)$ & $30(1)$ & $3(1)$ & 2(1) & $-15(1)$ \\
\hline $\mathrm{Cl}(2)$ & 24(1) & $30(1)$ & $38(1)$ & $-7(1)$ & $10(1)$ & $-14(1)$ \\
\hline $\mathrm{F}$ & $49(1)$ & $33(1)$ & $36(1)$ & $-15(1)$ & $-3(1)$ & $-6(1)$ \\
\hline $\mathrm{O}(1)$ & $23(1)$ & $21(1)$ & $29(1)$ & $1(1)$ & $3(1)$ & $-9(1)$ \\
\hline
\end{tabular}




\begin{tabular}{lllllll}
$\mathrm{O}(2)$ & $17(1)$ & $20(1)$ & $21(1)$ & $1(1)$ & $3(1)$ & $-9(1)$ \\
$\mathrm{O}(3)$ & $16(1)$ & $21(1)$ & $29(1)$ & $-7(1)$ & $2(1)$ & $-11(1)$ \\
$\mathrm{O}(4)$ & $14(1)$ & $22(1)$ & $30(1)$ & $4(1)$ & $-3(1)$ & $-8(1)$ \\
$\mathrm{O}(5)$ & $22(1)$ & $30(1)$ & $34(1)$ & $2(1)$ & $-2(1)$ & $-18(1)$ \\
\hline
\end{tabular}

Table 17: Hydrogen coordinates $\left(\mathrm{x} 10^{4}\right)$ and isotropic displacement parameters $\left(\AA^{2} \times 10^{3}\right)$ for compound 211.

\begin{tabular}{|c|c|c|c|c|}
\hline & $\mathrm{x}$ & $\mathrm{y}$ & $\mathrm{z}$ & $\mathrm{U}(\mathrm{eq})$ \\
\hline $\mathrm{H}(1)$ & 12298 & 12093 & 6065 & 25 \\
\hline $\mathrm{H}(4)$ & 18244 & 4726 & 5954 & 27 \\
\hline $\mathrm{H}(5)$ & 14995 & 5300 & 6474 & 26 \\
\hline $\mathrm{H}(8)$ & 8044 & 8137 & 6853 & 22 \\
\hline $\mathrm{H}(9 \mathrm{~A})$ & 8483 & 4705 & 7156 & 28 \\
\hline $\mathrm{H}(9 \mathrm{~B})$ & 11182 & 3854 & 7159 & 28 \\
\hline $\mathrm{H}(10 \mathrm{~A})$ & 11244 & 4127 & 8107 & 25 \\
\hline $\mathrm{H}(10 \mathrm{~B})$ & 9187 & 3508 & 8094 & 25 \\
\hline $\mathrm{H}(13 \mathrm{~A})$ & 5766 & 11797 & 7900 & 24 \\
\hline $\mathrm{H}(13 \mathrm{~B})$ & 5892 & 11493 & 7233 & 24 \\
\hline $\mathrm{H}(15 \mathrm{~A})$ & 8165 & 5893 & 8976 & 25 \\
\hline $\mathrm{H}(15 \mathrm{~B})$ & 9800 & 6993 & 8817 & 25 \\
\hline $\mathrm{H}(17)$ & 8601 & 10829 & 8970 & 35 \\
\hline $\mathrm{H}(18)$ & 6087 & 14068 & 9402 & 40 \\
\hline $\mathrm{H}(20)$ & 1427 & 11804 & 9550 & 34 \\
\hline $\mathrm{H}(21)$ & 3967 & 8539 & 9122 & 30 \\
\hline $\mathrm{H}(3)$ & 11235 & 8384 & 7893 & 31 \\
\hline
\end{tabular}




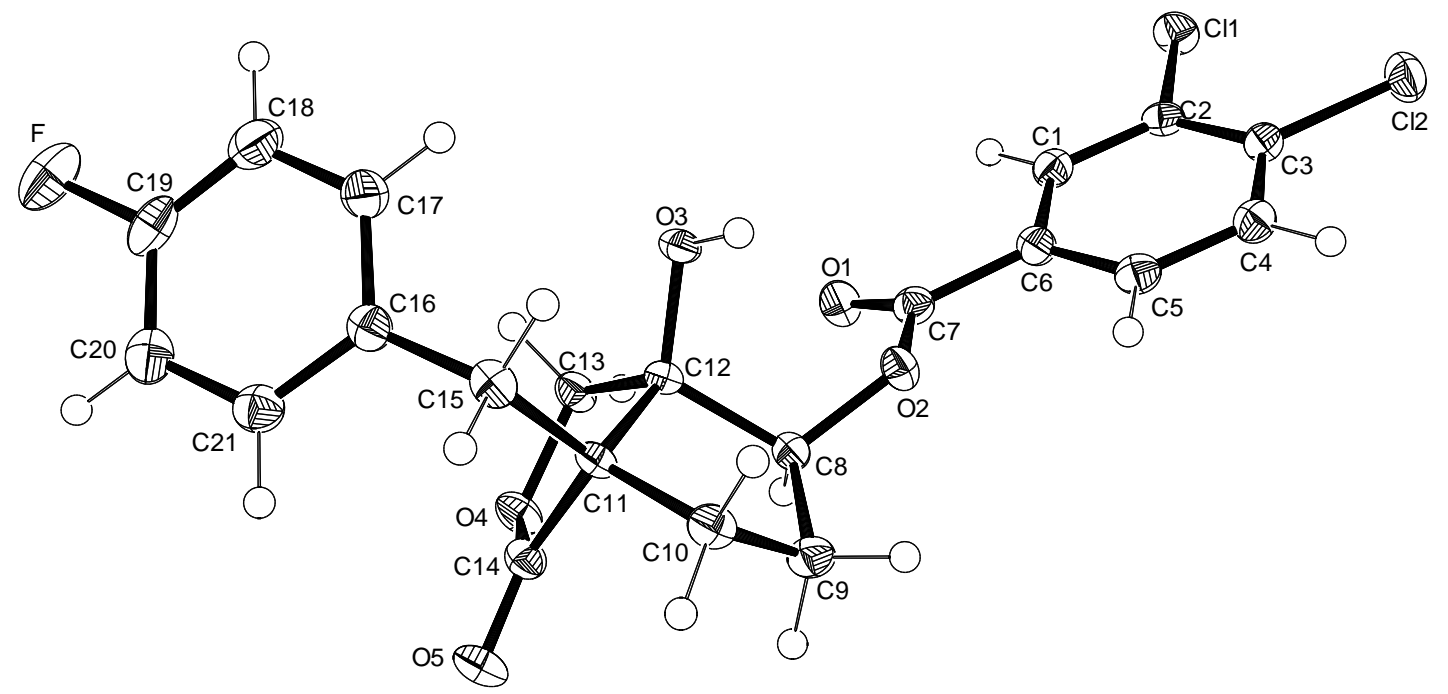

Figure 3: Ortep plot of compound 211 (thermal ellipsoids are set at the 50\% probability level). 